\title{
WestVirginiaUniversity
}

THE RESEARCH REPOSITORY @ WVU

Graduate Theses, Dissertations, and Problem Reports

2002

\section{Vanadate-induced cell cycle regulation and its signal transduction pathway}

Zhuo Zhang

West Virginia University

Follow this and additional works at: https://researchrepository.wvu.edu/etd

\section{Recommended Citation}

Zhang, Zhuo, "Vanadate-induced cell cycle regulation and its signal transduction pathway" (2002).

Graduate Theses, Dissertations, and Problem Reports. 1655.

https://researchrepository.wvu.edu/etd/1655

This Dissertation is protected by copyright and/or related rights. It has been brought to you by the The Research Repository @ WVU with permission from the rights-holder(s). You are free to use this Dissertation in any way that is permitted by the copyright and related rights legislation that applies to your use. For other uses you must obtain permission from the rights-holder(s) directly, unless additional rights are indicated by a Creative Commons license in the record and/ or on the work itself. This Dissertation has been accepted for inclusion in WVU Graduate Theses, Dissertations, and Problem Reports collection by an authorized administrator of The Research Repository @ WVU.

For more information, please contact researchrepository@mail.wvu.edu. 


\title{
DISSERTATION
}

\section{VANADATE-INDUCED CELL CYCLE REGULATION AND ITS SIGNAL TRANSDUCTION PATHWAY}

\section{Zhuo Zhang}

Dissertation submitted to the

School of Pharmacy

At West Virginia University

In partial fulfillment of the requirements

for the degree of

\author{
Doctor of Philosophy \\ In \\ Pharmaceutical Sciences \\ Xianglin Shi, Ph.D., Chair \\ Vincent Castranova, Ph.D. \\ Daniel C. Flynn, Ph.D. \\ Robert L. Haining, Ph.D. \\ Yongyut Rojanasakul, Ph.D \\ Val Vallyathan, Ph.D. \\ Department of Basic Pharmaceutical Sciences \\ Morgantown, West Virginia \\ 2002
}

Keywords: vanadate, cell cycle, reactive oxygen species (ROS), MAP kinase, p53, p21, PI-3 kinase, PKB/Akt, p70 S6 kinase 


\begin{abstract}
Vanadate-induced Cell Cycle Regulation and its Signal Transduction Pathway
\end{abstract}

\title{
Zhuo Zhang
}

Vanadate is potent toxic and carcinogenic agent. The mechanisms of its toxic and carcinogenic actions are still under investigation. Cell cycle arrest is an important mechanism in maintaining genomic stability and integrity in response to environmental stress. The present study investigated the possible mechanisms involved in vanadateinduced cell cycle arrest and its signal transduction pathway. The results show that vanadate caused $\mathrm{G}_{2} / \mathrm{M}$ phase arrest $\mathrm{A} 549$ cells. p21 and cdc25C affected on cyclin $\mathrm{B} / \mathrm{cdc} 2$ complex, resulting in the cell cycle arrest at $\mathrm{G}_{2} / \mathrm{M}$ phase. p38 and extracellular signal-regulated protein kinase (ERK) were involved in the regulation of these cell cycle regulatory proteins. Furthermore, reactive oxygen species (ROS), especially, hydrogen peroxide $\left(\mathrm{H}_{2} \mathrm{O}_{2}\right)$, mediated vanadate-induced $\mathrm{G}_{2} / \mathrm{M}$ phase arrest. The effect of $\mathrm{p} 53$, a tumor suppressor gene, also was examined in the present study. It has been shown that vanadate-induced S phase arrest was dependent on p53 through p21 pathway. Both p38 and ERK acted as upstream regulators of p53. However, the role of p53 is both phaseand cell line-specific. Vanadate-induced $\mathrm{G}_{2} / \mathrm{M}$ phase arrest is $\mathrm{p} 53$-independent in mouse embryo fibroblasts. It has been reported that phosphatidylinositol-3 kinase (PI3K) and its down stream kinases, protein kinase B (PKB)/Akt and p70 S6 kinase (p70S6K) play an essential role in control of transcription and protein synthesis, which impact on cell growth, survival and metabolism. The present study investigated the effects of these kinases on vanadate-induced cell cycle arrest and its regulation. It has been found that vanadate activated both PI3K and Akt, which in turn caused hyperphosphorylation of retinoblastoma protein $(\mathrm{pRb})$ and increased E2F1 expression. Induction of E2F1 activated cyclin $\mathrm{E}$ which triggered $\mathrm{G}_{1} / \mathrm{S}$ transition. Vanadate was also able to cause phosphorylation of p70S6K through PI3K-dependent pathway. Activation of p70S6K affected on $\mathrm{p} 21$, and $\operatorname{cdc} 25 \mathrm{~A}$, leading to inactivation of cdk2. Therefore, inactivation of cdk2 caused the cells being unable to progress from $S$ to $G_{2}$ phase. The present study provides a molecular basis for understanding the mechanisms of vanadate-induced cellular responses, and furthers understanding of the carcinogenic process induced by this metal. 
Dedicated to $\mathrm{my}$

Mom and Dad 


\section{ACKNOWLEDGEMENTS}

This dissertation is dedicated to my family, especially to my mother. Her constant love, care, and support, in particular her great courage for fighting against the devil cancer are the fundamental force that drives me through these years to fulfill my dreams and to reach my destinations.

I am deeply indebted to my graduate advisor, Dr. Xianglin Shi, for his exceptional academic guidance and advice in every aspect of my study, from many hour-lasting thought-provoking discussion to sharp and exploratory criticisms, from bench work to manuscript writing, which are all essential for completion of my graduate study.

My appreciation also goes to my graduate committee members, Dr. Vincent Castranova, Dr. Daniel C. Flynn, Dr. Peter M Gannett, Dr. Robert L. Haining, Dr. Yongyut Rojanasakul, and Dr. Val Vallyathan for their time, effort, advice, comments, suggestions, encouragement, and patience throughout my study.

I would also like to express my appreciation to: Dr. Fei Chen and Dr. Yong Qian, who are always available to offer their help and their expertise in research; Dr. Chuanshu Huang, a model of scientist who provides me the inspiration to excel in science; Dr. Suwei Wang, who is not just my senior, but also my friend for sharing with me the cheerful as well as gloomy moments in the past several years; Jacquelyn Bower, Leon Butterworth, Deborah Cutler, Dr. Ning Gao, Dr. Gabriel K. Harris, Dr. Binhua Jiang, Dr. Robert Lanciotti, Stephen Leonard, Jingxia Li, Yongju Lu, Donna L. Pack, and Dr. Liying Wang for their valuable help and contribution.

Last, but not least, my fellow students, Shuiying Hu, Yi Jing, and Bin Lu for making my life at Morgantown enjoyable. 
TABLE OF CONTENTS

ABSTRACT

ACKNOWLEDGEMENTS iv

TABLE OF CONTENTS $\quad \mathrm{V}$

LIST OF TABLES viii

LIST OF FIGURES L ix

OVERVIEW

I. SECTION I: Vadanate induces cell cycle arrest through MAPKs and reactive oxygen species

1. Abstract 18

2. Introduction 19

3. Materials and Methods 21

4. Results 24

5. Discussion 30

6. Figures 33

7. References 49

II. SECTION II: Vanadate-induced S phase arrest is p53-dependent through activation of $\mathrm{p} 21$ in $\mathrm{C} 141$ cells

1. Abstract 57

2. Introduction $\quad 58$

3. Materials and Methods 60

4. Results 62

5. Discussion 64

6. Figures 68

$\begin{array}{ll}\text { 7. References } & 79\end{array}$ 
III. SECTION III: Vanadate induces $\mathrm{G}_{2} / \mathrm{M}$ phase arrest in $\mathrm{p} 53$

$$
\text { deficient mouse embryo fibroblasts }
$$

1. Abstract 85

2. Introduction 86

3. Materials and Methods $\quad 88$

4. Results 90

5. Discussion 93

6. Figures 96

$\begin{array}{ll}\text { 7. References } & 107\end{array}$

IV. SECTION IV: MAPKs mediate $\mathrm{S}$ phase arrest induced by vanadate through a p53 dependent pathway in mouse epidermal C141 cells

1. Abstract 114

2. Introduction 115

3. Materials and Methods 117

4. Results 119

5. Discussion 122

6. Figures 126

$\begin{array}{ll}\text { 7. References } & 138\end{array}$

V. SECTION V: Involvement of E2F1-pRb in vanadate-induced S phase arrest through Akt pathway

1. Abstract 146

2. Introduction 147

3. Materials and Methods 149

4. Results 151

5. Discussion 154 
6. Figures 159

$\begin{array}{ll}\text { 7. References } & 175\end{array}$

VI. SECTION VI: The role of phosphatidylinositol-3 kinase and p70 S6 kinase in vanadate-induced S phase arrest

1. Abstract 181

2. Introduction 182

3. Materials and Methods 185

4. Results 187

5. Discussion 189

6. Figures 192

7. References 207

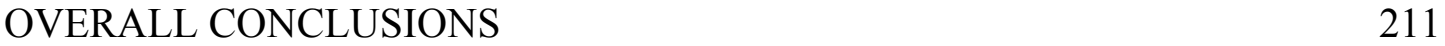

$\begin{array}{ll}\text { CURRICULUM VITAE } & 212\end{array}$ 


\section{LIST OF TABLES}

1. Time-dependence of vanadate-induced p53 activity 132

2. Dose-dependence of vanadate-induced p53 activity 133

3. Effects of MAPKs on p53 activity 


\section{LIST OF FIGURES}

\section{SECTION I}

1. Vanadate-induced cell growth arrest

2. Effects of vanadate on cell growth regulatory proteins

3. Vanadate-induced phosphorylation of ERK and p38

4. Inhibitory effects of ERK and p38 inhibitors on vanadate-induced activation of ERK and $\mathrm{p} 38$

5. Inhibitory effects of ERK and p38 inhibitors on vanadate-induced cell growth arrest

6. Effects of ERK and p38 inhibitors on vanadate-regulated cell growth regulatory proteins

7. Hydroxyl radical formation induced by vanadate and the effects of antioxidants

8. Formation of $\mathrm{H}_{2} \mathrm{O}_{2}$ and $\mathrm{O}_{2}{ }^{\bullet-}$ induced by vanadate and the effects of antioxidants detected by flow cytometry.

9. Formation of $\mathrm{H}_{2} \mathrm{O}_{2}$ and $\mathrm{O}_{2}{ }^{\bullet-}$ induced by vanadate and the effects of antioxidants detected by confocal microscopy

10. Measurement of oxygen consumption

11. Effects of antioxidants on vanadate-activated ERK and p38.

12. Effects of antioxidants on vanadate regulated cell growth regulatory proteins

13. Schematic representation of possible mechanisms of vanadate (V)induced cell growth arrest and its regulation via generation of $\mathrm{H}_{2} \mathrm{O}_{2}$ in A549 cells 


\section{SECTION II}

1. Vanadate-induced cell growth arrest in C141 cells

2. The effect of vanadate on cell growth in p53-deficient embryo fibroblasts

3. Vanadate-induced p53 activation in C141 cells

4. Inhibitory effects of PFT on vanadate-induced cell growth arrest in C141 cells

5. Inhibitory effects of PFT on vanadate-induced p53 activation in C141 cells

6. Time dependence of vanadate on p21 level in C141 cells and p53 -/- cells

7. Dose-response study of vanadate on p21 level in C141 cells and p53 -/- cells

8. The inhibitory effects of PFT on p21 expression in C141 cells

\section{SECTION III}

1. Effects of vanadate on cell growth arrest in both p53 -/- and p53 $+/+$ cells

2. Effects of vanadate on cell growth inhibitory protein $\mathrm{p} 21$ in both p53 -/- and p53+/+ cells

3. Effects of vanadate on cell growth regulatory protein cdc $25 \mathrm{C}$

4. Effects of vanadate on cell growth regulatory protein cdc25A

5. Effects of vanadate on cell cycle checkpoint cdc2 


\section{SECTION IV}

1. Leakage of cytosolic lactate dehydrogenase (LDH) from C141 cells exposed to various concentrations of vanadate for $24 \mathrm{~h}$

2. Time dependence of vanadate-induced cell growth arrest in C141 cells

3. Concentration dependence of vanadate-induced cell growth arrest in $\mathrm{C} 141$ cells

4. Effects of vanadate on growth regulatory proteins in C141 cells

5. Activation of $\mathrm{p} 38$ and ERK by vanadate in C141 cells

6. Inhibitory effects of PD98059 and SB202190 on vanadateactivated ERK and p38in C141 cells

7. Effects of MAPKs inhibitors on vanadate-induced cell growth arrest in C141 cells

8. Inhibitory effects of MAPKs inhibitors on vanadate-regulated growth proteins in C141 cells

\section{SECTION V}

1. Effects of vanadate on cell cycle arrest at S phase in C141 cells

2. Effects of vanadate on cell growth regulatory proteins in C141 cells 161

3. Effects of vanadate on Akt 162

4. Effects of Akt on cell cycle arrest 163

5. Effects of Akt on cell growth regulatory proteins 168

6. Effects of PI3K on Akt activity 171

7. Effects of PI3K on Akt phosphorylation 172 


\section{SECTION VI}

1. Effects of vanadate on cell growth regulatory proteins in both C141 cells and $\Delta$ p85 cells

2. Effects of vanadate on PI3K activity and cell cycle regulatory proteins in $\mathrm{C} 141$ cells

3. Effects of vanadate on $\mathrm{p} 70 \mathrm{~S} 6 \mathrm{~K}$ in both $\mathrm{C} 141$ cells and $\Delta \mathrm{p} 85$ cells

4. Effects of PI3K on p70S6K in C141 cells and in DN p70S6K mutant cells

5. Effects of both PI3K and p70S6 kinase on cell cycle arrest

6. Role of p70S6K on cell cycle regulatory proteins 


\section{OVERVIEW}

Vanadium is widespread in the environment and is a trace metal in biological systems. It exists in water, rocks, and soil in low concentrations and in coal and oil deposits in relatively high concentrations. Vanadium is widely found in mining, steel and steel-alloy making, and in the chemical industry. In the periodic table, vanadium belongs to the first transition series and can form compounds in valences III, IV and V. The vanadium (III) species are unstable at physiological $\mathrm{pH}$ and in the present of oxygen. Vanadium (IV) is easily oxidized to vanadium (V) under physiological conditions and vanadium (V) species are found as vanadate anions. Workers occupationally exposed to vanadium are at risk as respirable particulates may penetrate deep into the pulmonary tract. Epidemiological studies have shown a correlation between vanadium exposure and the incidence of lung cancer in humans $(1,2)$. While the mechanisms of vanadium's toxicity and carcinogenicity remain to be investigated, it has been reported that this metal is able to regulate growth factor mediated signal transduction pathways, promote cell transformation, exert inhibitory effect on certain enzymatic systems, and decrease cell adhesion (3-5). Vanadium compounds were also reported to cause direct DNA damage such as strand breaks and hydroxylation of $\mathrm{dG}$ residues (6), activate certain transcription factors, such as AP-1 (7), NF-B (8), p53 (9) and nuclear factor of activated T cells (NFAT) and induce apoptosis $(10,11)$.

Phosphotyrosine phosphatases (PTPs) serve as important regulators of cellular signal transduction pathways. PTPs are sensitive targets of oxidative stress and may be inhibited by treatments that induce intracellular oxidation (12). The PTP inactivation under oxidizing conditions that amplified by the redox-linked activation of key protein tyrosine kinase (PTKs) leads to the initiation of phosphotyrosine-signaling cascades that

are no longer under normal receptor control (12). These ligand-independent signals result in the accumulation of protein phosphotyrosine, the generation of second messengers, the activation of downstream kinases, and the nuclear translocation of 
nuclear factors kappa B (NF-кB) (12). Vanadium compounds have been widely used as PTP inhibitors, and their efficiency has been demonstrated in animal models and human clinical trials of insulin-resistant diabetes mellitus (13). It has been reported that reactive oxygen species (ROS) are involved in downstream signaling between PTPase inhibition and NF- $\mathrm{KB}$ activation (14). As an insulin-mimetic agent, peroxovanadate promoted glucose transport, and activated both phosphatidylinositol 3-kinase (PI3K) and Akt in adipocytes (15). It is believed that peroxovanadate functions by inhibiting tyrosine phosphatase, which results in an increase in the level of tyrosine phosphorylation of many signaling proteins, thus triggering signaling pathways normally regulated by growth factors (16). The activation of signaling pathways and the induction of related genes by oxidative stress can alter the functional development of affected cells, leading to such diverse outcomes as cellular proliferation and apoptosis (17). In addition, it has been found that pervanadate induced tyrosine phosphorylation of the platelet-derived growth factor (PDGF)-beta receptor, interaction of the phosphorylated PDGF receptor with extracellular signal-regulated kinase (ERK) activation and DNA synthesis (18). The contribution of both tyrosine phosphatase inhibition and oxidative stress of these effects has not been established. The current understanding suggests that both two factors may be important.

Proliferation and cell cycle progression are functionally linked to the expression of genes associated with growth control. Both cause and effect relationships between the factors that modulate the cell division cycle exist, reflecting multidirectional signaling between segments of regulatory cascades that operate selectively in specific cells and tissues. The integration of positive and negative regulatory signals is appreciated in a broad spectrum of biological contexts. These include: (a) repeated traverse of the cell cycle for cleavage divisions during the initial stages of embryogenesis and continued renewal of stem cell population; (b) stimulation of quiescent cells to proliferate for tissue remodeling and wound healing; and (c) exit from the cell cycle with the option to 
subsequently proliferate or terminally differentiate. The important is an appreciation of the cell regulatory mechanisms that are compromised in transformed and tumor cells and in non-malignant disorders, where there are abnormalities in cell cycle and/or growth control (19). The cornerstone for investigations into mammalian cell cycle control is the documentation by A. Howard and S. R. Pelc, nearly five decades ago, that proliferation of eukaryotic cells requireds discrete periods of DNA synthesis (S phase) and mitotic division (M) with a postsynthetic, premitotic period designated $\mathrm{G}_{2}$ and a postmitotic, presynthetic period designated $\mathrm{G}_{1}$. The ability of cells to maintain genomic integrity is vital for cell survival and proliferation. Lack of fidelity in DNA replication and maintenance can result in deleterious mutations leading to cell death or, in multicellular organisms, cancer (20). Signal transduction pathways play a key role in the regulation of cell cycle progression and stabilization of DNA under genotoxic stress. Cell-cycle checkpoints control the onset of DNA replication and mitosis in order to ensure the integrity of the genome $(21,22)$. Since vanadate is a DNA damaging agent and a carcinogen, the cells may undergo growth arrest upon exposure to this metal to prevent the cells with damaged DNA from proliferation. Thus investigation of vanadate-induced cell cycle arrest is an important for understanding the overall mechanism of vanadateinduced carcinogenesis.

\section{Role of MAPKs and ROS in vanadate-induced cell cycle arrest (Section I)}

Recent advance indicates that reactive oxygen species (ROS) may function as intracellular messengers to modulate signaling pathways $(23,24)$. The changes of intracellular ROS have been detected in a variety of cells stimulated with cytokines, growth factors and agonists of receptors $(25,26)$. Various studies have demonstrated that many protein kinases and transcription regulatory factors are activated under the conditions of oxidative stress (24, 27-31). Mitogen-activated protein kinases (MAPKs) cascades are protein kinase signal transduction pathways that have been remarkably

conserved in evolution. They are differentially used to relay numerous extracellular 
signals within cells (32-34). These MAPK cascades have been found to be involved in such diverse cellular functions as proliferation, differentiation, stress responses, and apoptosis. Stress-activated protein kinases (SAPK)/Jun N-terminal kinase (JNK), p38 and extracellular signal-related kinase (ERK), are the most widely studied members of MAPK family. Recent studies have shown that ROS can activate MAPK (29-31), leading to abnormal $\mathrm{M}$ phase transition in the cell cycle (35). Oxidative stress may be a biological outcome of the p38 MAPK-mediated spindle checkpoint arrest that has been demonstrated by microinjection of active p38 or by nocodazole treatment in Xenopus embryos and mouse cells (36). It has been reported that under oxidative stress, cycling cells will exhibit cell cycle checkpoint response $(37,38)$. It has been demonstrated that vanadate-mediated generation of ROS plays an important role in its adverse biological effects $(39,40)$.

Using the human alveolar epithelial cell line, A549, the present study investigates the role of ROS and ERK and p38 protein kinase in vanadate-induced cell growth arrest. Exposure of cells to vanadate led to cell growth arrest at the $\mathrm{G}_{2} / \mathrm{M}$ phase and caused upregulation of p21 and phospho-cdc 2 and degradation of $\operatorname{cdc} 25 \mathrm{C}$ in a time- and dosedependent manner. Vanadate induced activation of MAPKs family members, ERK and p38, as determined by their phosphorylation. PD98059, an inhibitor of ERK, and SB202190, an inhibitor of p38, not only decreased phosphorylation of ERK and p38 in response to vanadate, but also inhibited vanadate-induced cell growth arrest, upregulation of p21 and cdc2 and degradation of cdc25C. Cellular reduction of vanadate generated hydroxyl radical $\left({ }^{\circ} \mathrm{OH}\right)$ as determined by electron spin resonance (ESR), and superoxide radical $\left(\mathrm{O}_{2}{ }^{\circ-}\right)$ and hydrogen peroxide $\left(\mathrm{H}_{2} \mathrm{O}_{2}\right)$ as determined by flow cytometry and confocal microscopy using specific dyes. Generation of $\mathrm{O}_{2}{ }^{--}$and $\mathrm{H}_{2} \mathrm{O}_{2}$ was inhibited by specific antioxidant enzymes, superoxide dismutase (SOD) and catalase, respectively. It can be concluded that ROS activate ERK and p38, which in turn up-regulate p21 and cdc 2 and cause degradation of cdc25C leading to cell growth arrest at $\mathrm{G}_{2} / \mathrm{M}$ phase. 
Specific ROS affect different MAPK family members and cell growth regulatory proteins with different potencies.

\section{Role of p53 in vanadate-induced cell cycle arrest (Sections II and III)}

p53 is important for securing the stability and integrity of the genome of normal cells and was suggested to be the 'guardian of the genome' (41). A variety of DNA insults were shown to stabilize the protein, which in turn can either cause growth arrest, permit the induction of the DNA repair process, or alternatively, direct cells to undergo apoptosis (42). p53 was suggested to be a sensor of damaged DNA, and be involved in the repair process (43). The p53 tumor suppressor is a multifunctional protein that exerts a variety of different effects and plays a central role in the regulation of the normal cell cycle $(44,45)$.

It has been reported that both p53-dependent and p53-independent pathways are involved in the cell cycle regulation (46). p53-dependent cell growth arrest in $\mathrm{G}_{1}$ phase is an important component of the cellular response to stress. Recent study indicates that p53 controls the entry into mitosis when cells enter $\mathrm{G}_{2}$ phase with damaged DNA or when they are arrested in $\mathrm{S}$ phase due to depletion of the substrates required for DNA synthesis (47). p21 (WAF-1/CIP1) is known to be a transactivation target of p53, and is believed to mediate p53-induced growth arrest triggered by DNA damage $(48,49)$. Induction of p21 expression could serve as an indicator for transactivation by p53, although p21 was also shown to be transactivated by p53-independent mechanisms (50).

The present study investigated the regulation of p53 on vanadate-induced $\mathrm{S}$ phase arrest using both p53 wild type C141 cells and p53 deficient embryo fibroblasts (p53 -/-). On vanadate stimulation, C141 cells exhibited a dose- and time-dependent S phase arrest as determined by DNA content analysis. In contrast, vanadate was unable to increase the percentage of $\mathrm{S}$ phase in p53 -/- cells. Luciferase assay showed that 
vanadate induced p53 activation in a dose- and time-dependent manner in p53 wild type C141 cells. Addition of pifithrin- $\alpha$ (PFT), a specific inhibitor of p53, reduced the activation of p53 with a concomitant decrease in growth arrest at S phase. Western blotting analysis demonstrated that vanadate caused a dose- and time-dependent increase of p21 level in C141 cells. Pretreatment of C141 cells with PFT decreased p21 expression induced by vanadate while the p21 expression did not vary in vanadate stimulated p53 -/- cells. The results obtained from the present study suggest that vanadate is able to induce $\mathrm{S}$ phase arrest through p53 and p21-dependent pathway.

The present study also investigated the role of p53 in vanadate-induced $\mathrm{G}_{2} / \mathrm{M}$ phase arrest and its regulation, two cell lines, normal mouse embryo fibroblasts (p53+/+) and p53 deficient mouse embryo fibroblasts (p53 -/-), were used in the present study. The results show that in p53 -/- cells vanadate induced $\mathrm{G}_{2} / \mathrm{M}$ phase arrest in a dose- and timedependent manner without alteration of S phase. In p53 +/+ cells, vanadate treatment increased $\mathrm{S}$ phase with no significant change at $\mathrm{G}_{2} / \mathrm{M}$ phase. Furthermore, Western blotting results show that in p53 -/- cells vanadate caused cdc $25 \mathrm{C}$ degradation and activation of phospho-cdc2 without alteration of p21 level. In p53 +/+ cells, vanadate increased expression of $\mathrm{p} 21$ and degraded cdc25A instead of $\operatorname{cdc} 25 \mathrm{C}$ without any effect on cdc2. These results demonstrate that vanadate induced $\mathrm{G}_{2} / \mathrm{M}$ phase arrest in p53 deficient mouse embryo fibroblasts, and caused S phase arrest in p53 wild type mouse embryo fibroblasts.

\section{Interaction of MAPKs and p53 in vanadate-induced cell cycle arrest (Section IV)}

The p53 tumor suppressor protein appears to serve numerous functions during the cellular response to genotoxic stress, some of which act as a transcription factor to activate gene expression (51). p53 is considered an important mediator in the cell cycle. Various kinases including double-stranded DNA-activated protein kinase (DNA-PK), cyclin A and cyclin B-associated kinase cdc2, ERK and JNK have been implicated in p53 
phosphorylation that in turn participates in regulation of p53 activity $(6,7,52)$. It has been reported that $\mathrm{p} 53$ activation correlated with prominent activation of ERK1/2 MAP kinases that resulted from colcemid-stimulated development of focal adhesions that caused $\mathrm{G}_{1}$ phase arrest (53). In addition, phosphorylation of p53 by p38 plays a role in p53-dependent transcription (37).

The present study investigated the involvement of MAP kinases in vanadateinduced cell growth arrest and the relationship of p53. DNA content analysis showed that vanadate induced S phase arrest is time- and dose-dependent in p53 wild type C141 cells but not in p53 deficient C141 cells. Western blotting results indicated that vanadate caused an inactivation of p-cdk2 at Thr160, which is an important kinase for the progression of S phase, and an increase in expression of $\mathrm{p} 21$, which is a key for $\mathrm{S}$ phase arrest. In p53 deficient cells, vanadate did not induce any observable change in p21 or p-cdk2 level. In addition, vanadate up-regulated phospho-p38 and ERK, two members of MAP kinases. At the same time, vanadate increased the p53 activity as measured by luciferase assay. Addition of PD98059 and SB202190, inhibitors of ERK and p38, respectively, decreased vanadate-induced S phase arrest, reduced p21 level, restored activation of p-cdk2, and decreased p53 activity. The study demonstrated that vanadate-induced S phase arrest is mediated by both ERK and p38 in p53-dependent pathway.

\section{Involvement of E2F1-pRb in vanadate-induced cell cycle arrest through Akt pathway (Section V)}

Mammalian cells require an extracellular proliferative signal directly after mitosis in order to keep on growing and dividing. When cells are faced with a lack of such a signal, they will either die or go into growth arrest in a postmitotic $\mathrm{G}_{1}$ phase. One of important intracellular signaling pathways that transduce such proliferative signals is PI3K pathway (54). The proto-oncogene protein kinase (PKB), known as Akt, is a major target 
of PI3K signaling in the control of cell proliferation, as it is involved in anti-apoptotic signaling as well as cell cycle control (55).

Although the mechanisms by which PKB contributes to the regulation of apoptosis have become better defined, relatively little is known concerning its role in the regulation of cell cycle progression (55). A recent study has demonstrated that the cellcycle regulator E2F is a component of the downstream proliferative machinery regulated by Akt (56). One of the key events in $\mathrm{G}_{1}$ phase is the activation of E2F, which in turn binds to promoters and trans-activates various genes critical for cell cycle progression, such as cyclin E (55). The E2F family of transcription factors are important regulators of the $\mathrm{G}_{1} / \mathrm{S}$ cell cycle transition, because E2F can activate expression of the $\mathrm{S}$ phase regulatory genes necessary for initiating DNA replication (57). E2F is a repressor when complexed with a member of the retinoblastoma $(\mathrm{Rb})$ family of pocket proteins $(58,59)$. The continuation of cell proliferation at various stages of the cell cycle involves inactivation of at least one of three members of the $\mathrm{Rb}$ family (54). The $\mathrm{pRb}$ protein is an essential component of the $\mathrm{G}_{1} / \mathrm{S}$ checkpoint $(60)$. pRb is present at relatively constant levels throughout the cell cycle but is hyperphosphorylated by cyclin/cdk complexes and released from $\mathrm{E} 2 \mathrm{~F} 1$ at the $\mathrm{G}_{1} / \mathrm{S}$ transition, allowing continuation through the cell cycle (61).

The present study shows that in normal C141 cells, vanadate treatment increased percentage of the cells at $\mathrm{S}$ phase and elevated cyclin $\mathrm{E}$ and cyclin A expression. Vanadate treatment triggered phosphorylation of $\mathrm{pRb}$ and release of E2F1. Furthermore, vanadate increased both Akt kinase activity and caused phosphorylation at Ser473 and Thr308. Inhibition of Akt by either inhibitors or transfected cells with dominant negative kinase mutant or dominant negative phosphorylation mutant decreased the percentage of the cells at the $\mathrm{S}$ phase induced by vanadate, and reduced both cyclin E and E2F1 expression and phosphorylation of $\mathrm{pRb}$. The present study indicates that Akt plays an essential role in vanadate-induced $S$ phase arrest and transition from $G_{1}$ to $S$ phase 
through E2F-pRb pathway.

\section{The role of PI3K and p70S6K in vanadate-induced cell cycle arrest (Section VI)}

One of the important downstream targets of PI3K is p70 S6 protein kinase (p70S6K). The importance of this kinase at a molecular level is that it is involved in the selective translational regulation of a unique family of mRNAs, by mediating the multiple phosphorylation of 40S ribosomal protein S6 (62). These mRNAs encode for components of the translational apparatus, including ribosomal proteins and translational elongation factors whose increased expression is essential for cell growth and proliferation (63).

The present study investigated the role of PI3K in vanadate-induced cell cycle arrest in C141 mouse epidermal cells. Vanadate caused a dose-dependent increase in p21 and decrease in both cdc25A and cdk2. In $\Delta$ p85 cells, vanadate did not alter these cell cycle regulatory proteins. Vanadate caused a time- and dose-dependent increase in PI3K activity through phosphorylation of p70 S6 kinase (p70S6K) at Thr421/Ser424 and Thr389 sites. The phosphorylation at these sites was inhibited both by PI3K inhibitor, LY294002, and p70S6K mutation. Moreover, vanadate induced S phase arrest was inhibited by LY294002 and rapmycin, a p70S6K inhibitor. Vanadate-induced S phase arrest was also inhibited in transfection with dorminant negeative p70S6K mutant cells. In these cells, vanadate-induced activation of p21 and the degradation of cdc25A and cdk2 were inhibited. Taken together the results obtained show that vanadate is able to increase PI3K activity through phosphorylation. PI3K activated p70S6K, which phosphated protein S6 and controlled the cell cycle regulatory proteins and blocked vanadate-induced cell cycle arrest at $\mathrm{S}$ phase. 


\section{REFERENCES}

1. Hickey, R.J., Schoff, E.P. and Clelland, R.C. (1967) Relationship between air pollution and certain chronic disease death rates. Multivariate statistical studies. Arch Environ Health, 15, 728-38.

2. Stock, P. (1965) On the relations between atmospheric pollution in urban and rural location and mortality from cancer, bronchitis, pneumonia, with particular reference to 3,4-benzopyrene, beryllium, molybdenum, vanadium and arsenic. $\mathrm{Br}$. J. Cancer, 14, 397-418.

3. Cruz, T.F., Morgan, A. and Min, W. (1995) In vitro and in vivo antineoplastic effects of orthovanadate. Mol Cell Biochem, 153, 161-6.

4. Swarup, G., Cohen, S. and Garbers, D.L. (1982) Inhibition of membrane phosphotyrosyl-protein phosphatase activity by vanadate. Biochem Biophys Res Commun, 107, 1104-9.

5. Stern, A., Yin, X., Tsang, S.S., Davison, A. and Moon, J. (1993) Vanadium as a modulator of cellular regulatory cascades and oncogene expression. Biochem Cell Biol, 71, 103-12.

6. Shi, X., Jiang, H., Mao, Y., Ye, J. and Saffiotti, U. (1996) Vanadium(IV)-mediated free radical generation and related 2'- deoxyguanosine hydroxylation and DNA damage. Toxicology, 106, 27-38.

7. $\quad$ Ding, M., Li, J.J., Leonard, S.S., Ye, J.P., Shi, X., Colburn, N.H., Castranova, V. and Vallyathan, V. (1999) Vanadate-induced activation of activator protein-1: role of reactive oxygen species. Carcinogenesis, 20, 663-8.

8. Ye, J., Ding, M., Zhang, X., Rojanasakul, Y., Nedospasov, S., Vallyathan, V., Castranova, V. and Shi, X. (1999) Induction of TNFalpha in macrophages by vanadate is dependent on activation of transcription factor NF-kappaB and free radical reactions. Mol Cell Biochem, 198, 193-200.

9. Huang, C., Zhang, Z., Ding, M., Li, J., Ye, J., Leonard, S.S., Shen, H.M., Butterworth, L., Lu, Y., Costa, M., Rojanasakul, Y., Castranova, V., Vallyathan, 
V. and Shi, X. (2000) Vanadate induces p53 transactivation through hydrogen peroxide and causes apoptosis. $J$ Biol Chem, 275, 32516-22.

10. Huang, C., Ding, M., Li, J., Leonard, S.S., Rojanasakul, Y., Castranova, V., Vallyathan, V., Ju, G. and Shi, X. (2001) Vanadium-induced nuclear factor of activated T cells activation through hydrogen peroxide. J Biol Chem, 276, 22397403.

11. Ye, J., Ding, M., Leonard, S.S., Robinson, V.A., Millecchia, L., Zhang, X., Castranova, V., Vallyathan, V. and Shi, X. (1999) Vanadate induces apoptosis in epidermal JB6 P+ cells via hydrogen peroxide-mediated reactions. Mol Cell Biochem, 202, 9-17.

12. Krejsa, C.M. and Schieven, G.L. (1998) Impact of oxidative stress on signal transduction control by phosphotyrosine phosphatases. Environ Health Perspect, 106 Suppl 5, 1179-84.

13. Goldfine, A.B., Simonson, D.C., Folli, F., Patti, M.E. and Kahn, C.R. (1995) In vivo and in vitro studies of vanadate in human and rodent diabetes mellitus. Mol Cell Biochem, 153, 217-31.

14. Kang, J.L., Pack, I.S., Lee, H.S. and Castranova, V. (2000) Enhancement of nuclear factor-kappaB activation and protein tyrosine phosphorylation by a tyrosine phosphatase inhibitor, pervanadate, involves reactive oxygen species in silica-stimulated macrophages. Toxicology, 151, 81-9.

15. Wijkander, J., Holst, L.S., Rahn, T., Resjo, S., Castan, I., Manganiello, V., Belfrage, P. and Degerman, E. (1997) Regulation of protein kinase B in rat adipocytes by insulin, vanadate, and peroxovanadate. Membrane translocation in response to peroxovanadate. $J$ Biol Chem, 272, 21520-6.

16. Grillo, S., Gremeaux, T., Casamayor, A., Alessi, D.R., Le Marchand-Brustel, Y. and Tanti, J.F. (2000) Peroxovanadate induces tyrosine phosphorylation of phosphoinositide-dependent protein kinase-1 potential involvement of src kinase. Eur J Biochem, 267, 6642-9.

17. Corcoran, G.B., Fix, L., Jones, D.P., Moslen, M.T., Nicotera, P., Oberhammer, 
F.A. and Buttyan, R. (1994) Apoptosis: molecular control point in toxicity. Toxicol Appl Pharmacol, 128, 169-81.

18. Boulven, I., Robin, P., Desmyter, C., Harbon, S. and Leiber, D. (2002) Differential involvement of Src family kinases in pervanadate-mediated responses in rat myometrial cells. Cell Signal, 14, 341-9.

19. Stein, G.S., Wijnen A., Lian J.B., Owen T.A. (2002) Cell cycle. Encyclopedia of life sciences, 1-9.

20. Shackelford, R.E., Kaufmann, W.K. and Paules, R.S. (1999) Cell cycle control, checkpoint mechanisms, and genotoxic stress. Environ Health Perspect, 107 Suppl 1, 5-24.

21. Hartwell, L.H. and Kastan, M.B. (1994) Cell cycle control and cancer. Science, 266, 1821-8.

22. Mercer, W.E. (1998) Checking on the cell cycle. J Cell Biochem Suppl, 31, 50-4.

23. Cheng, T.H., Shih, N.L., Chen, S.Y., Wang, D.L. and Chen, J.J. (1999) Reactive oxygen species modulate endothelin-I-induced c-fos gene expression in cardiomyocytes. Cardiovasc Res, 41, 654-62.

24. Schreck, R., Rieber, P. and Baeuerle, P.A. (1991) Reactive oxygen intermediates as apparently widely used messengers in the activation of the NF-kappa B transcription factor and HIV-1. Embo J, 10, 2247-58.

25. Nakamura, K., Fushimi, K., Kouchi, H., Mihara, K., Miyazaki, M., Ohe, T. and Namba, M. (1998) Inhibitory effects of antioxidants on neonatal rat cardiac myocyte hypertrophy induced by tumor necrosis factor-alpha and angiotensin II. Circulation, 98, 794-9.

26. Lander, H.M. (1997) An essential role for free radicals and derived species in signal transduction. Faseb J, 11, 118-24.

27. Adler, V., Yin, Z., Fuchs, S.Y., Benezra, M., Rosario, L., Tew, K.D., Pincus, M.R., Sardana, M., Henderson, C.J., Wolf, C.R., Davis, R.J. and Ronai, Z. (1999) Regulation of JNK signaling by GSTp. Embo J, 18, 1321-34.

28. Kurata, S. (1996) Sensitization of the HIV-1-LTR upon long term low dose 
oxidative stress. J Biol Chem, 271, 21798-802.

29. Kyriakis, J.M., Banerjee, P., Nikolakaki, E., Dai, T., Rubie, E.A., Ahmad, M.F., Avruch, J. and Woodgett, J.R. (1994) The stress-activated protein kinase subfamily of c-Jun kinases. Nature, 369, 156-60.

30. Raingeaud, J., Gupta, S., Rogers, J.S., Dickens, M., Han, J., Ulevitch, R.J. and Davis, R.J. (1995) Pro-inflammatory cytokines and environmental stress cause p38 mitogen- activated protein kinase activation by dual phosphorylation on tyrosine and threonine. J Biol Chem, 270, 7420-6.

31. Stein, B., Brady, H., Yang, M.X., Young, D.B. and Barbosa, M.S. (1996) Cloning and characterization of MEK6, a novel member of the mitogen- activated protein kinase kinase cascade. J Biol Chem, 271, 11427-33.

32. Cohen, P. (1997) The search for physiological substances of MAP and SAP kinases in mammalian cells. Trends Cell Biol., 7, 353-361.

33. Fanger, G.R., Gerwins, P., Widmann, C., Jarpe, M.B. and Johnson, G.L. (1997) MEKKs, GCKs, MLKs, PAKs, TAKs, and tpls: upstream regulators of the c- Jun amino-terminal kinases? Curr Opin Genet Dev, 7, 67-74.

34. Herskowitz, I. (1995) MAP kinase pathways in yeast: for mating and more. Cell, 80, 187-97.

35. Kurata, S. (2000) Selective activation of p38 MAPK cascade and mitotic arrest caused by low level oxidative stress. J Biol Chem, 275, 23413-6.

36. Takenaka, K., Moriguchi, T. and Nishida, E. (1998) Activation of the protein kinase p38 in the spindle assembly checkpoint and mitotic arrest. Science, 280, 599-602.

37. Carpenter, G. (1981) Vanadate, epidermal growth factor and the stimulation of DNA synthesis. Biochem Biophys Res Commun, 102, 1115-21.

38. Hori, C.a.O., T. (1987) Vanadate enhances the stimulatory action of insurin on DNA synthesis in cultured mouse mammary glands. Biochim. Biophys. Acta, 610, 235-240.

39. Sabbioni, E., Pozzi, G., Pintar, A., Casella, L. and Garattini, S. (1991) Cellular 
retention, cytotoxicity and morphological transformation by vanadium(IV) and vanadium(V) in BALB/3T3 cell lines. Carcinogenesis, 12, 47-52.

40. Nechay, B.R., Nanninga, L.B. and Nechay, P.S. (1986) Vanadyl (IV) and vanadate (V) binding to selected endogenous phosphate, carboxyl, and amino ligands; calculations of cellular vanadium species distribution. Arch Biochem Biophys, 251, 128-38.

41. Lane, D.P. (1992) Cancer. p53, guardian of the genome. Nature, 358, 15-6.

42. Livingstone, L.R., White, A., Sprouse, J., Livanos, E., Jacks, T. and Tlsty, T.D. (1992) Altered cell cycle arrest and gene amplification potential accompany loss of wild-type p53. Cell, 70, 923-35.

43. Sanchez, Y. and Elledge, S.J. (1995) Stopped for repairs. Bioessays, 17, 545-8.

44. Almog, N. and Rotter, V. (1997) Involvement of p53 in cell differentiation and development. Biochim Biophys Acta, 1333, F1-27.

45. Rotter, V., Aloni-Grinstein, R., Schwartz, D., Elkind, N.B., Simons, A., Wolkowicz, R., Lavigne, M., Beserman, P., Kapon, A. and Goldfinger, N. (1994) Does wild-type p53 play a role in normal cell differentiation? Semin Cancer Biol, 5, 229-36.

46. Taylor, W.R. and Stark, G.R. (2001) Regulation of the G2/M transition by p53. Oncogene, 20, 1803-15.

47. Chan, T.A., Hwang, P.M., Hermeking, H., Kinzler, K.W. and Vogelstein, B. (2000) Cooperative effects of genes controlling the $\mathrm{G}(2) / \mathrm{M}$ checkpoint. Genes Dev, 14, 1584-8.

48. Harper, J.W., Adami, G.R., Wei, N., Keyomarsi, K. and Elledge, S.J. (1993) The p21 Cdk-interacting protein Cip1 is a potent inhibitor of G1 cyclin- dependent kinases. Cell, 75, 805-16.

49. el-Deiry, W.S., Tokino, T., Velculescu, V.E., Levy, D.B., Parsons, R., Trent, J.M., Lin, D., Mercer, W.E., Kinzler, K.W. and Vogelstein, B. (1993) WAF1, a potential mediator of p53 tumor suppression. Cell, 75, 817-25.

50. Michieli, P., Chedid, M., Lin, D., Pierce, J.H., Mercer, W.E. and Givol, D. (1994) 
Induction of WAF1/CIP1 by a p53-independent pathway. Cancer Res, 54, 3391-5.

51. Anderson, C.W. (1993) DNA damage and the DNA-activated protein kinase. Trends Biochem Sci, 18, 433-7.

52. Holbrook, N.J., Liu, Y. and Fornace, A.J., Jr. (1996) Signaling events controlling the molecular response to genotoxic stress. Exs, 77, 273-88.

53. Heichman, K.A. and Roberts, J.M. (1994) Rules to replicate by. Cell, 79, 557-62.

54. Kops, G.J., Medema, R.H., Glassford, J., Essers, M.A., Dijkers, P.F., Coffer, P.J., Lam, E.W. and Burgering, B.M. (2002) Control of cell cycle exit and entry by protein kinase B-regulated forkhead transcription factors. Mol Cell Biol, 22, 202536.

55. Coffer, P.J., Jin, J. and Woodgett, J.R. (1998) Protein kinase B (c-Akt): a multifunctional mediator of phosphatidylinositol 3-kinase activation. Biochem $\mathrm{J}$, $335,1-13$.

56. Brennan, P., Babbage, J.W., Burgering, B.M., Groner, B., Reif, K. and Cantrell, D.A. (1997) Phosphatidylinositol 3-kinase couples the interleukin-2 receptor to the cell cycle regulator E2F. Immunity, 7, 679-89.

57. Dyson, N. (1998) The regulation of E2F by pRB-family proteins. Genes Dev, 12, 2245-62.

58. Weinberg, R.A. (1995) The retinoblastoma protein and cell cycle control. Cell, 81, 323-30.

59. Weintraub, S.J., Prater, C.A. and Dean, D.C. (1992) Retinoblastoma protein switches the E2F site from positive to negative element. Nature, 358, 259-61.

60. Bosco, G., Du, W. and Orr-Weaver, T.L. (2001) DNA replication control through interaction of E2F-RB and the origin recognition complex. Nat Cell Biol, 3, 28995.

61. Sherr, C.J. (1996) Cancer cell cycles. Science, 274, 1672-7.

62. Jefferies, H.B., Fumagalli, S., Dennis, P.B., Reinhard, C., Pearson, R.B. and Thomas, G. (1997) Rapamycin suppresses 5'TOP mRNA translation through inhibition of p70s6k. Embo J, 16, 3693-704. 
63. Amaldi, F. and Pierandrei-Amaldi, P. (1997) TOP genes: a translationally controlled class of genes including those coding for ribosomal proteins. Prog Mol Subcell Biol, 18, 1-17. 


\section{SECTION I}

\section{Vanadate Induces Cell Growth Arrest through MAPKs and Reactive Oxygen Species}




\section{I.1. ABSTRACT}

Cell growth arrest is an important mechanism in maintaining genomic stability and integrity in response to environmental stress. Using the human alveolar epithelial cell line, A549, the present study investigates the role of reactive oxygen species (ROS) and extracellular signal-regulated protein kinase (ERK) and p38 protein kinase in vanadateinduced cell growth arrest. Exposure of cells to vanadate led to cell growth arrest at the $\mathrm{G}_{2} / \mathrm{M}$ phase and caused up-regulation of p21 and phospho-cdc2 and degradation of cdc $25 \mathrm{C}$ in a time- and dose-dependent manner. Vanadate stimulated mitogen-activated protein kinases (MAPKs) family members, as determined by the phosphorylation of ERK and p38. PD98059, an inhibitor of ERK, and SB202190, an inhibitor of p38, not only decreased phosphorylation of ERK and p38 in response to vanadate, but also inhibited vanadate-induced cell growth arrest, up-regulation of p21 and cdc2 and degradation of cdc25C. Cellular reduction of vanadate generated hydroxyl radical $\left({ }^{\circ} \mathrm{OH}\right)$ as determined by electron spin resonance (ESR), and superoxide radical $\left(\mathrm{O}_{2}{ }^{-*}\right)$ and hydrogen peroxide $\left(\mathrm{H}_{2} \mathrm{O}_{2}\right)$ as determined by flow cytometry and confocal microscopy using specific dyes. Generation of $\mathrm{O}_{2}{ }^{--}$and $\mathrm{H}_{2} \mathrm{O}_{2}$ was inhibited by specific antioxidant enzymes, superoxide dismutase (SOD) and catalase, respectively. ROS activate ERK and p38, which in turn up-regulate p21 and cdc2 and cause degradation of cdc25C leading to cell growth arrest

at $\mathrm{G}_{2} / \mathrm{M}$ phase. Specific ROS affect different MAPK family members and cell growth regulatory proteins with different potencies. 


\section{I.2. INTRODUCTION}

Vanadium is an essential transition trace element found in some plants and animals. It is widely distributed in rocks, soil, and to a lesser extent in water (1-3). Vanadium compounds $(\mathrm{V}(\mathrm{V}))$ exert potent toxic effects on a wide variety of biological systems $(1,4-8)$. This metal regulates growth factor mediated signal transduction pathways, promotes cell transformation and decreases cell adhesion (9-11). Occupational exposure to vanadium occurs in mining, petrochemical industries and coal and oil fired plants. Epidemiological studies have shown a correlation between vanadium exposure and the incidence of lung cancer in humans $(6,8,12,13)$. Vanadium compounds were reported to modify DNA synthesis and repair (14-16). Vanadate induced forward mutations and DNA-protein crosslinks in cultured mammalian cells (17). While the biochemical mechanism of vanadium carcinogenicity is still not fully understood, recent studies have indicated that vanadium-mediated generation of reactive oxygen species (ROS) may play an important role (18-26). For example, through ROS, vanadium caused 2'-deoxyguanosine hydroxylation and DNA damage (26), apoptosis (27,28), and activation of nuclear transcription factors (21), AP-1 and NF-кB (29).

In mammalian cells, cell cycle transition is under the control of a tightly regulated network of cell division kinases (cdks) and a number of surveillance mechanisms, the socalled checkpoints (30). In most normal cells DNA damage arrests proliferation in $\mathrm{G}_{1} / \mathrm{S}$ or $\mathrm{G}_{2} / \mathrm{M}$ phase and then resume proliferation after the damage is repaired (30). The cell cycle controls the onset of DNA replication and mitosis in order to ensure the integrity of the genome (31-33). Lack of fidelity in DNA replication and maintenance can result in deleterious mutations, leading to cell death or, in multicellular organisms, cancer (30).

Recent advance indicates that ROS may function as intracellular messengers to modulate signaling pathways $(34,35)$. The changes of intracellular ROS have been 
detected in a variety of cells stimulated with cytokines, growth factors and agonists of receptors (35-37). Various experiments provide evidence that many protein kinases and transcription regulatory factors are activated under the conditions of oxidative stress (35,38-42). Mitogen-activated protein kinases (MAPKs) cascades are protein kinase signal transduction pathways that have been remarkably conserved in evolution. They are differentially used to relay numerous extracellular signals within cells (43-45). These MAPK cascades have been found to be involved in such diverse cellular functions as proliferation, differentiation, stress responses, and apoptosis. Stress-activated protein kinases (SAPK)/Jun N-terminal kinase (JNK); p38 and extracellular signal-related kinase (ERK) are the most widely studied members of MAPK family. Recent studies have shown that ROS can activate MAPK (40-42), leading to abnormal M phase transition in the cell cycle (46). Oxidative stress may be a biological outcome of the p38 MAPKmediated spindle checkpoint arrest that has been demonstrated by microinjection of active p38 or by nocodazole treatment in Xenopus embryos and mouse cells (47). Although ROS are frequently mentioned in the literature to be inducers for MAPKs, many of the studies are indirect, for example, N-acetylcysteine (NAC) was used as an inhibitor (48). The link between ROS and cell growth arrest is not yet eatablished. Many questions remain to be answered. For example, (a) do ROS play a key role in induction of cell growth arrest; (b) which species among ROS are involved; (a) are MAPKs involved in ROS-mediated cell growth arrest; (d) do ROS affect cell growth regulatory proteins. In the present study, vanadate was used as an inducer of ROS because this metal is capable of generating a whole spectrum of ROS, i.e., $\mathrm{H}_{2} \mathrm{O}_{2}, \mathrm{O}_{2}{ }^{\circ}$, and ${ }^{\circ} \mathrm{OH}$ in the stimulation of the cells. ESR, confocal microscopy and flow cytometry, Western blotting in combination with various specific antioxidants were used in the present study to investigate the role of ROS induced by vanadate in ERK and p38 kinase signal transduction pathway in cell growth arrest. 


\section{I.3. MATERIALS AND METHODS}

Chemicals Sodium metavanadate and 5,5-dimethyl-1-pyraline-N-oxide (DMPO) were purchased from Aldrich (Milwaukee, WI). RNase A and superoxide dismutase (SOD) were from Sigma (St. Louis, MO). Catalase was from Roche Molecular Biochemicals (Indianapolis, IN). Propidium iodide (PI), 2', 7'-dichlorofluorescin diacetate (DCFH-DA), dihydroethidium (HE), and tetramethylrhodamine-5-(and-6-)isothiocyanate (TRITC) were from Molecular Probes (Eugene, OR). Both F12K nutrient mixture medium and fetal bovine serum (FBS) were from Gibco BRL (Life Technologies, Gaithersburg, MD). PD98058 and SB202190 were from Calbiochem (San Diego, CA). Antibodies to p21 and cdc25C were from Santa Cruz Biotechnology (Santa Cruz, CA). Antibodies to p38, ERK, and phospho-cde $2^{\text {Tyr15 }}$ and second AP linked antirabbit IgG were from Cell Signaling (Beverly, MA). The spin trap, DMPO, was purified by charcoal decolorization. DMPO solution, thus purified, did not contain any ESRdetectable impurities.

Cell culture The human alveolar epithelial cell line, A549, was cultured in F12K nutrient mixture medium containing 10\% FBS, $2 \mathrm{mM} \mathrm{L-glutamine} \mathrm{and} 1000 \mathrm{U} / \mathrm{ml}$ penicillin-streptomycin in an incubator at $5 \% \mathrm{CO}_{2}$ and $37^{\circ} \mathrm{C}$.

Measurement of cell cycle/DNA content DNA content in $\mathrm{G}_{1} / \mathrm{S}, \mathrm{G}_{2} / \mathrm{M}$ phase was detected using flow cytometry $(49,50)$. A549 cells were fixed and permeabilized with $70 \%$ ice-cold ethanol for more than $2 \mathrm{~h}$, and incubated with the freshly prepared staining buffer $(0.1 \%$ Triton X-100 in PBS, $200 \mu \mathrm{g} / \mathrm{ml} \mathrm{RNase} \mathrm{A,} \mathrm{and} 20 \mu \mathrm{g} / \mathrm{ml} \mathrm{PI})$ for $15 \mathrm{~min}$ at $37^{\circ} \mathrm{C}$. Cell cycle analysis was performed by flow cytometry with at least 10,000 cells for each sample. The histogram was abstracted and the percentage of cells in the $\mathrm{G}_{1} / \mathrm{S}$ and $\mathrm{G}_{2} / \mathrm{M}$ phase was then calculated using ModFit LT software. 
Western blotting analysis Whole cell extracts were mixed with Tris-Glycine SDS sample buffer and then subjected to Tris-Glycine gel electrophoresis. The resolved proteins were transferred to a PVDF membrane. Western blotting was performed using antibodies against p21, cdc25C, phospho-cdc2 ${ }^{\text {Tyr15 }}$, p38, ERK and second anti-rabbit IgG. After reaction with ECF substrate, the signal was detected using a Storm Scanner (Molecular Dynamics, Sunnyvale, CA).

Electron spin resonance (ESR) measurements ESR spin trapping was used to examine free radical generation. This technique involves an addition-type reaction of a short-lived radical with a diamagnetic compound (spin trap) to form a relatively longlived free radical product, the so-called spin adduct, which can be studied by conventional ESR (51). The intensity of the spin adduct signal corresponds to the amount of short-lived radicals trapped, and the hyperfine splittings of the spin adduct are generally characteristic of the original, short-lived, trapped radical.

All measurements were conducted using a Varian E9 ESR spectrometer and a flat cell assembly as described previously $(52,53)$. The relative radical concentration was calculated by multiplying one half of the peak height by $\left(\Delta \mathrm{H}_{\mathrm{pp}}\right)^{2}$, where $\Delta \mathrm{H}_{\mathrm{pp}}$ represents peak-to-peak width. A549 cells were mixed with DMPO to a total final volume of 0.5 ml. The reaction mixture was transferred to a flat cell and measurements were made after $10 \mathrm{~min}$.

Cellular hydrogen peroxide $\left(\mathrm{H}_{2} \mathrm{O}_{2}\right)$ and superoxide anion $\left(\mathrm{O}_{2}{ }^{\circ}\right)$ assay Both flow cytometry and confocal microscopy were used to measure the generation of $\mathrm{H}_{2} \mathrm{O}_{2}$ and $\mathrm{O}_{2}{ }^{\circ-}$ . DCFH-DA is a specific molecular probe for $\mathrm{H}_{2} \mathrm{O}_{2}$, and $\mathrm{HE}$ is specific dye for $\mathrm{O}_{2}{ }^{\circ}$. The principle of this assay is that DCFH-DA diffuses through the cell membrane and is enzymatically hydrolyzed by intracellular esterases to non-fluorescent dichlorofluorescin (DCFH). In the presence of $\mathrm{H}_{2} \mathrm{O}_{2}$, this compound is rapidly oxidized to highly 
fluorescent dichlorofluorescein (DCF) $(54,55)$. HE, a blue fluorescent dye, is oxidized to ethidium that stains nucleus a bright fluorescent red (27). TRITC is an important fluorophore for preparing protein conjugates (56). A549 cells were cultured in 6-well plates containing $5 \times 10^{5}$ cells in each well. The cells were treated with $100 \mu \mathrm{M}$ vanadate for $1 \mathrm{~h}$. DCFH-DA or HE (final concentration, $5 \mu \mathrm{M}$ ) was added to the cells and incubated for another 15-20 min prior to measurement of fluorescence. Cells were harvested, washed twice with PBS, and then analyzed using flow cytometry. For the confocal analysis of $\mathrm{H}_{2} \mathrm{O}_{2}$, DCFH-DA was added to the cells together with $2.5 \mu \mathrm{M}$ TRITC for 15-20 min prior to the measurement. TRITC was used as another dye to observe the presence of the cells because DCFH-DA is colorless unless it is oxidized by $\mathrm{H}_{2} \mathrm{O}_{2}$. For the confocal analysis of $\mathrm{O}_{2}{ }^{\circ}$, only $\mathrm{He}$ was used because this dye itself exhibited fluorescent blue.

Oxygen consumption assay The reaction mixtures contained $1 \times 10^{6} / \mathrm{ml}$ cells and $100 \mu \mathrm{M}$ vanadate. Oxygen consumption was determined using a Gilson oxygraph equipped with a Clark eletrode. The oxygraph was calibrated with medium equilibrated with oxygen of known concentrations. 


\section{I.4. RESULTS}

Effect of vanadate on the cell cycle DNA content was measured by flow cytometry to investigate vanadate-induced cell growth arrest. Human alveolar epithelial cells, the A549 cell line, were exposed to vanadate for $24 \mathrm{~h}$ with various concentrations of vanadate. The results show that after $24 \mathrm{~h}$ exposure, $100 \mu \mathrm{M}$ vanadate caused growth arrest $(45.24 \%)$ at $\mathrm{G}_{2} / \mathrm{M}$ phase (Figure 1). Figure $1 \mathrm{~A}$ shows the time dependence of vanadate-induced $\mathrm{G}_{2} / \mathrm{M}$ phase arrest. At a vanadate concentration of $100 \mu \mathrm{M}$, vanadateinduced $\mathrm{G}_{2} / \mathrm{M}$ phase arrest peaked at $24 \mathrm{~h}$. Effects of vanadate concentration in the ranges of 10-200 $\mu \mathrm{M}$ were examined after a $24 \mathrm{~h}$ exposure. An increase in vanadate concentration increased the percentage of $\mathrm{G}_{2} / \mathrm{M}$ phase (Figure 1B).

Effect of vanadate on cell growth regulatory proteins Several cell growth regulatory proteins, p21, phospho-cdc 2 and cdc25C were examined by Western blotting. The results are shown in Figure 2. Treatment of the A549 cells with $100 \mu \mathrm{M}$ vanadate for different times increased the levels of both p21 and phosphorylated cdc2 (left panel). Treatment of the cells with $100 \mu \mathrm{M}$ vanadate for $6 \mathrm{~h}$ slightly increased the cdc $25 \mathrm{C}$ level. An increase in incubation time caused degradation of $\operatorname{cdc} 25 \mathrm{C}$ and further exposure of the cells to $48 \mathrm{~h}$ completely degraded cdc $25 \mathrm{C}$.

The dose dependent effects of vanadate on these three growth regulatory proteins were also examined. As shown in Figure 2 (right panel), vanadate caused a dosedependent increase in the levels of both p21 and phosphorylated cdc2. $25 \mu \mathrm{M}$ vanadate caused degradation of cdc $25 \mathrm{C}$ and $100 \mu \mathrm{M}$ almost completely degraded this regulatory protein.

Activation of MAPK induced by vanadate The influences of vanadate on the phosphorylation of ERK and p38 were examined by Western blotting using antibodies 
specific for the phosphorylated MAPKs in A549 cells. Exposure of the cells to vanadate stimulated the phosphorylation of both ERK and p38 (Figure 3). The phosphorylation was relatively rapid and remained high level from $1 \mathrm{~h}$ to $4 \mathrm{~h}$ for both ERK and p38 (left panel). To study the dose dependence of the phosphorylation of both ERK and p38, A549 cells were treated for $4 \mathrm{~h}$ with various concentrations of vanadate. A dose-related increase in both ERK and p38 phosphorylation was observed in the cells treated with increasing concentrations of vanadate from $10 \mu \mathrm{M}$ to $200 \mu \mathrm{M}$ (right panel).

Inhibition of vanadate-induced activation of ERKs and p38 In the previous two sections, we have demonstrated that vanadate is able to stimulate phosphorylation of both ERK and p38. In this section, we examined the inhibitory effect of PD98059 and SB202190 on vanadate-induced activation of ERK and p38. As shown in Figure 4, pretreatment of the cells with PD98059 before vanadate exposure (100 $\mu \mathrm{M}$ for $4 \mathrm{~h})$ inhibited vanadate-stimulated phosphorylation of ERK. A similar inhibition of p38 phosphorylation was observed with SB202190.

Effect of ERK and p38 on vanadate-induced cell growth arrest ERK and p38 may affect vanadate-induced cell growth arrest through a signal transduction network. To test the role of ERK and p38 in vanadate-induced growth arrest, the A549 cells were exposed to $100 \mu \mathrm{M}$ vanadate for $24 \mathrm{~h}$ and cell cycle arrest was monitored by flow cytometry. As shown in Figure 5, exposure of the cells to vanadate caused cell growth arrest with $45.24 \%$ of the cells being retained in $\mathrm{G}_{2} / \mathrm{M}$ phase. For examination of the role of the ERK in vanadate-induced cell growth arrest, the cells were pretreated with PD98059, a specific MEK1-ERK pathway inhibitor, before exposure of cells to vanadate. The results show that pretreatment of the cells with PD98059 resulted in a marked inhibition of vanadate-induced cell growth arrest, decreasing the percent of cells in $\mathrm{G}_{2} / \mathrm{M}$ phase to $35.34 \%$ for $50 \mu \mathrm{M}$ PD98059 and $31.08 \%$ for $100 \mu \mathrm{M}$ PD98059, respectively. Pretreatment of the cells with SB202190, a specific inhibitor of p38 also inhibited vanadate-induced cell growth arrest, decreasing the percent of cells in $G_{2} / M$ phase to 
$25.58 \%$ for $5 \mu \mathrm{M}$ SB202190 and $19.00 \%$ at $10 \mu \mathrm{M} \mathrm{SB} 202190$, respectively. Both of these two inhibitors alone had no effect on cell cycle, the $\mathrm{G}_{2} / \mathrm{M}$ phases stayed the same as control (data not shown). These results indicate that both ERK and p38 are involved in vanadate-induced cell growth arrest.

Inhibition of ERK and $p 38$ inhibitors on cell growth regulatory proteins To further show that vanadate-induced cell growth arrest is mediated by ERK and p38, we examined the effects of PD98059 and SB202190 on vanadate-induced p21 and phosphocdc2 levels and degradation of cdc25C. As shown in Figure 6, pretreatment of the cells with PD98059 or SB202190 decreased the levels of p21 and phospho-cdc2. Both of these two inhibitors also partially blocked the degradation of cdc25C observed after vanadate exposure.

Hydroxyl radical ( $\mathrm{OH})$ generation induced by vanadate It has been established that vanadate-mediated generation of ROS plays an important role in many cellular responses. For example, ROS generated by vanadate are involved in vanadateinduced DNA damage (26), activation of AP-1 and NF- $\mathrm{kB}$ (29), and apoptosis (52, 54). Using ESR spin trapping with DMPO as a spin trap, we examined vanadate-induced ${ }^{\circ} \mathrm{OH}$ generation. The use of a spin trap is necessary due to the reactive nature of the free radicals to be studied. This method is specific and sensitive and is considered to be the preferred one for detection and identification of free radical generation. As shown in Figure $7 \mathrm{a}$, cells alone generated a very weak signal. A mixture of cells and vanadate generated a relatively strong signal displaying a 1:2:2:1 quartet with $\mathrm{a}_{\mathrm{H}}=\mathrm{a}_{\mathrm{N}}=14.9 \mathrm{G}$ (Figure $7 b$ ), where $a_{H}$ and $a_{N}$ represent hyperfine splittings of the nitroxyl nitrogen and $\beta$ hydrogen, respectively, indicative of a $\mathrm{DMPO} /{ }^{\circ} \mathrm{OH}$ adduct. The detection of a $\mathrm{DMPO} /{ }^{\circ} \mathrm{OH}$ adduct indicates ${ }^{\circ} \mathrm{OH}$ radical generation. Addition of sodium formate, an 'OH radical scavenger and DMPO competitor, decreased the intensity of the DMPO/OH adduct signal and resulted in the appearance of a new spin adduct signal with the splitting 
constants $\mathrm{a}_{\mathrm{H}}=18.7$ and $\mathrm{a}_{\mathrm{N}}=15.7 \mathrm{G}$, which is indicative of a $\mathrm{DMPO} /{ }^{\circ} \mathrm{COO}^{-}$adduct (Figure 7c). The generation of ${ }^{\circ} \mathrm{COO}^{-}$radical was due to the abstraction of a hydrogen atom from formate by the ${ }^{\circ} \mathrm{OH}$ radical, a confirmation of ${ }^{\circ} \mathrm{OH}$ radical generation from vanadate-stimulated cells. Catalase, on the other hand, abolished the $\mathrm{DMPO} /{ }^{\bullet} \mathrm{OH}$ adduct signal (Figure 7d), indicating that (a) $\mathrm{H}_{2} \mathrm{O}_{2}$ is an important precursor for vanadateinduced ${ }^{\circ} \mathrm{OH}$ radical generation; and (b) $\mathrm{H}_{2} \mathrm{O}_{2}$ is generated in vanadate-stimulated cells.

Generation of $\mathrm{H}_{2} \mathrm{O}_{2}$ and $\mathrm{O}_{2}{ }^{-}$by vanadate-stimulated cells Flow cytometry and ROS dye were used to measure $\mathrm{H}_{2} \mathrm{O}_{2}$ and $\mathrm{O}_{2}{ }^{--}$generated by vanadate-stimulated cells. Although selective dyes (DCFH-DA for $\mathrm{H}_{2} \mathrm{O}_{2}$ and $\mathrm{HE}$ for $\mathrm{O}_{2}{ }^{\circ}$ ) were employed, it is still possible that these dyes may not be totally specific. To overcome this potential problem, various specific antioxidants were used in combination with the dye staining to determine specificity. As shown in Figure 8A, compared to control, treatment of the cells with 100 $\mu \mathrm{M}$ vanadate for $1 \mathrm{~h}$ increased the fluorescence peak intensity from 200 to 1050 , indicating that in vanadate-treated cells $\mathrm{H}_{2} \mathrm{O}_{2}$ generation was enhanced by more than 5 fold ( $a$ and $b)$. Pretreatment of the cells with SOD or formate did not decrease the fluorescence intensity ( $c$ and d). However, catalase decreased the intensity almost to the control level (e). Similar results were obtained using $\mathrm{HE}$ dye for $\mathrm{O}_{2}{ }^{--}$detection (Figure 8B). Vanadate increased the fluorescence intensity from 28 to 62 , indicating that $\mathrm{O}_{2}{ }^{--}$ generation was 2 times higher in vanadate-treated cells than control ( $a$ and $b$ ). SOD decreased the $\mathrm{O}_{2}{ }^{--}$generation to the control level (c), while neither formate nor catalase had a substantial effect ( $d$ and e).

In addition, the formation of $\mathrm{H}_{2} \mathrm{O}_{2}$ and $\mathrm{O}_{2}{ }^{--}$induced by vanadate was confirmed by confocal microscopy (Figure 9). As shown in Figure 9A, the cells were treated with TRITC to visualize unstimulated cells because DCFH-DA itself is colorless (left panel). The staining of the cells with TRITC resulted in a red color, allowing the same cells for analysis before and after treatment. Additionally, fluorescence can be produced only 
when DCFH-DA is oxidized to DCF in the presence of $\mathrm{H}_{2} \mathrm{O}_{2}$. For this reason the control cells could not be observed when DCFH-DA alone was added without vanadate treatment (a, right panel). In contrast, treatment with $100 \mu \mathrm{M}$ vanadate for $1 \mathrm{~h}$ results in a green fluorescence, which was evidence of vanadate-induced generation of $\mathrm{H}_{2} \mathrm{O}_{2}$ (b, right panel). Pretreatment with catalase, a specific scavenger of $\mathrm{H}_{2} \mathrm{O}_{2}$, sharply decreased the intensity of the green color, confirming that this signal was indeed due to $\mathrm{H}_{2} \mathrm{O}_{2}$ generation (c, right panel). Figure 9B shows the generation of $\mathrm{O}_{2}{ }^{\circ}$. The control cells were blue due to the addition of $\mathrm{HE}$ (a, left panel). In the presence of $\mathrm{O}_{2}{ }^{\circ}$, blue $\mathrm{HE}$ was oxidized to ethidium that fluoresces red. The red color observed in vanadate-treated cells indicated that vanadate indeed caused the generation of $\mathrm{O}_{2}{ }^{--}(b$, right panel). Addition of SOD, a scavenger of $\mathrm{O}_{2}{ }^{-}$, blocked the conversion of HE to ethidium. Therefore, the cells remained blue (c, left panel), confirming that $\mathrm{O}_{2}{ }^{--}$was indeed produced. As $\mathrm{O}_{2}{ }^{\bullet-}$ is the one-electron reduction product of molecular oxygen, the $\mathrm{O}_{2}$ consumption from cells was measured using an oxygraph. $\mathrm{O}_{2}$ consumption was $1600 \mathrm{nmol} / 10^{6}$ cells after vanadate treatment, whereas it was $1200 \mathrm{nmol} / 10^{6}$ cells in controls, i.e., vanadate significantly increased $\mathrm{O}_{2}$ consumption by $33 \%$ (Figure 10 ).

Effects of antioxidants on ERK and p38 In the previous sections, we have shown that vanadate-stimulated cells are able to generate ${ }^{\circ} \mathrm{OH}, \mathrm{H}_{2} \mathrm{O}_{2}$ and $\mathrm{O}_{2}{ }^{\cdot-}$. Since both ERK and p38 are oxidative stress-sensitive kinases (18), we examined the effects of antioxidants on vanadate-induced ERK and p38 activation. As shown in Figure 11, SOD, formate and catalase all inhibited activation of both ERK and p38 kinase. The inhibitory effect of catalase was more potent than formate and SOD. These results indicate that all ROS members were involved in the activation of MAPKs.

Effects of antioxidants on growth regulatory proteins The effects of antioxidants on several growth regulatory enzymes were examined. The results are shown in Figure 12. SOD, formate and catalase all exhibited inhibitory effect on vananade-induced p21 
level with catalase showing a stronger effect. Neither SOD nor formate had any observable effect on vanadate-induced phosphorylation of cdc2. However, catalase abolished it. Both SOD and formate partially blocked the degradation of cdc $25 \mathrm{C}$. In contrast, catalase enhanced the extent of vanadate-induced cdc $25 \mathrm{C}$ degradation. These results show ROS are involved in the regulation of these growth regulatory proteins. Specific ROS affect different regulatory proteins and exhibit different potencies. 


\section{I.5. DISCUSSION}

Although vanadate-containing compounds exert potent toxic and carcinogenic effects on a wide variety of biological systems, the mechanisms of their actions remain to be investigated. We hypothesize that vanadate-mediated free radical reactions may cause a persistent oxidative stress and play a key role in the mechanism of vanadate-induced carcinogenesis $(24,25)$. ROS generated by vanadate-mediated reactions are able to damage DNA (26). Normally, if the cell is injured by external agents, such as vanadate, it will respond to such injury by the activation of signal transduction pathways that control the modulation of transcription factors and regulation of gene expression as well as transiently delaying cell cycle progression to allow the repair of damaged DNA $(35,57)$. Alternatively, if the damage is too severe to be adequately repaired, the cell may undergo apoptosis or enter an irreversible senescence-like state (31). Our recent studies have shown that vanadate causes cell growth arrest and apoptosis through $\mathrm{H}_{2} \mathrm{O}_{2}$-mediated reactions $(27,28,58)$. The present study shows that vanadate is able to induce cell growth arrest and regulate cell growth regulatory enzymes through MAPKs and ROS.

MAPKs can be activated by many stress signals $(29,59,60)$. These kinases are serine/threonine protein kinases that participate in signal transduction of many extracellular stimuli, including UV light, bacterial derivatives, and growth factors. These stress-activated kinases have been implicated in the control of several diverse biological processes including cell proliferation, development, apoptosis, the response to stress, and the production of inflammatory cytokines (61). Activation of these kinases is marked by phosphorylation of serine/threonine amino residues in their protein molecules. They act as signal transducers at the end of kinase cascades that mediate signals from the cell to the nucleus. Activation of these kinases leads to induction of transcription factors that in turn regulate gene expression in the nucleus and cell proliferation. Recent studies have shown that MAPKs signaling pathways regulate the eukaryotic cell cycle (61). It has been reported that growth factors can trigger entry into $G_{1}$ phase of the cell cycle via 
activation of the Ras signaling pathway $(62,63)$. MAPKs also have been implicated in the regulation of the $\mathrm{G}_{2} / \mathrm{M}$ transition. In Xenopus oocytes, activation of MAPKs are necessary for progression from meiotic prophase I to metaphase II (64). After fertilization, inactivation of MAPKs is essential for the first $G_{2}$ to $M$ progression (65). It has been reported that MAPKs play an important role in the $\mathrm{G}_{2} / \mathrm{M}$ transition in mammalian cells (66). The present study shows that ERK and p38 are involved in vanadate-induced cell growth arrest because both PD98059 and SB202190 exhibit inhibitory effect with SB202190 being more potent. Inhibition of ERK or p38 also inhibited vanadate-induced expression of p21 and phospho-cdc2 and degradation of cdc25C. It appears that ERK and p38 regulate cell growth arrest at $\mathrm{G}_{2} / \mathrm{M}$ phase through these cell growth regulatory enzymes.

The results obtained from the present study show that ROS generated in vanadatestimulated cells are involved in vanadate-induced activation of ERK and p38, which in turn regulate cell growth regulatory enzymes leading to cell growth arrest. Our previous studies have shown that vanadate-stimulated cells consumed molecular oxygen that generated ROS in the process of vanadate reduction (58). Using ESR spin trapping, the present study detected ${ }^{\circ} \mathrm{OH}$ radical generation in vanadate-stimulate cells. $\mathrm{H}_{2} \mathrm{O}_{2}$ serves as a precursor for the generation of this radical. The generation of $\mathrm{H}_{2} \mathrm{O}_{2}$ and $\mathrm{O}_{2}{ }^{--}$were detected by flow cytometry and confocal microscopy in combination with specific scavengers for these species, catalase and SOD. From the results obtained in the present study and those reported previously (58), it can be concluded that molecular oxygen was consumed to generate $\mathrm{O}_{2}{ }^{--}$radical during the cellular reduction of vanadate; the $\mathrm{O}_{2}{ }^{--}$ radical produced $\mathrm{H}_{2} \mathrm{O}_{2}$ upon dismutation. $\mathrm{H}_{2} \mathrm{O}_{2}$ produced ${ }^{\circ} \mathrm{OH}$ radical via a Fenton-like reaction $\left(\mathrm{V}(\mathrm{IV})+\mathrm{H}_{2} \mathrm{O}_{2} \rightarrow{ }^{\circ} \mathrm{OH}+\mathrm{OH}^{-}+\mathrm{V}(\mathrm{V})\right)$. For vanadate-induced phosphorylation of p38, $\mathrm{O}_{2}{ }^{--}$has only minor effect; while both $\mathrm{H}_{2} \mathrm{O}_{2}$ and ${ }^{\circ} \mathrm{OH}$ are important with $\mathrm{H}_{2} \mathrm{O}_{2}$ exhibiting a stronger effect. For the phosphorylation of ERK, all of the ROS members are involved but none of them exhibits great potency. For both p21 and phospho-cdc2, $\mathrm{H}_{2} \mathrm{O}_{2}$ is essential. For cdc $25 \mathrm{C}$, although scavenging of $\mathrm{O}_{2}{ }^{--}$and ${ }^{\circ} \mathrm{OH}$ radical slightly 
decreased the cdc25C degradation, catalase enhanced cdc25C degradation. Probably the effects $\mathrm{H}_{2} \mathrm{O}_{2}$ of on cell cycle mainly is through p21 instead of cdc25C.

It may be noted that increasing evidence is accumulating that indicates a vital role for ROS in mediating cellular responses by various extracellular stimulators (37). ROS can be generated from many exogenous and endogenous sources in biological systems. Exogenous sources of ROS include tobacco smoke, toxic gases, vapors, chemicals, pollutants present in ambient air, asbestos, metals, and mineral particles (67). It is possible that these agents may activate MAPKs and alter the status of growth regulatory proteins, leading to cell growth arrest.

The results obtained from the present study support the following conclusions: (a) vanadate induces cell growth arrest at $\mathrm{G}_{2} / \mathrm{M}$ phase; (b) vanadate causes phosphorylation of ERK and p38; (c) vanadate up-regulates p21 and cdc2 and causes degradation of cdc25C through both ERK and p38 pathways; (d) during the cellular reduction of vanadate, molecular oxygen is reduced to generate ROS; (e) ROS are involved in vanadate-induced activation of ERK and p38, expression of p21 and cdc2 and degradation of cdc25C; and (f) it may be speculated that other metal carcinogens and mineral particles, such as asbestos, chromium, cobalt, nickel, and silica, that are ROSpromoting agents, may also cause cell growth arrest by a mechanism similar to that of vanadate. 


\section{I.6. FIGURES}

A
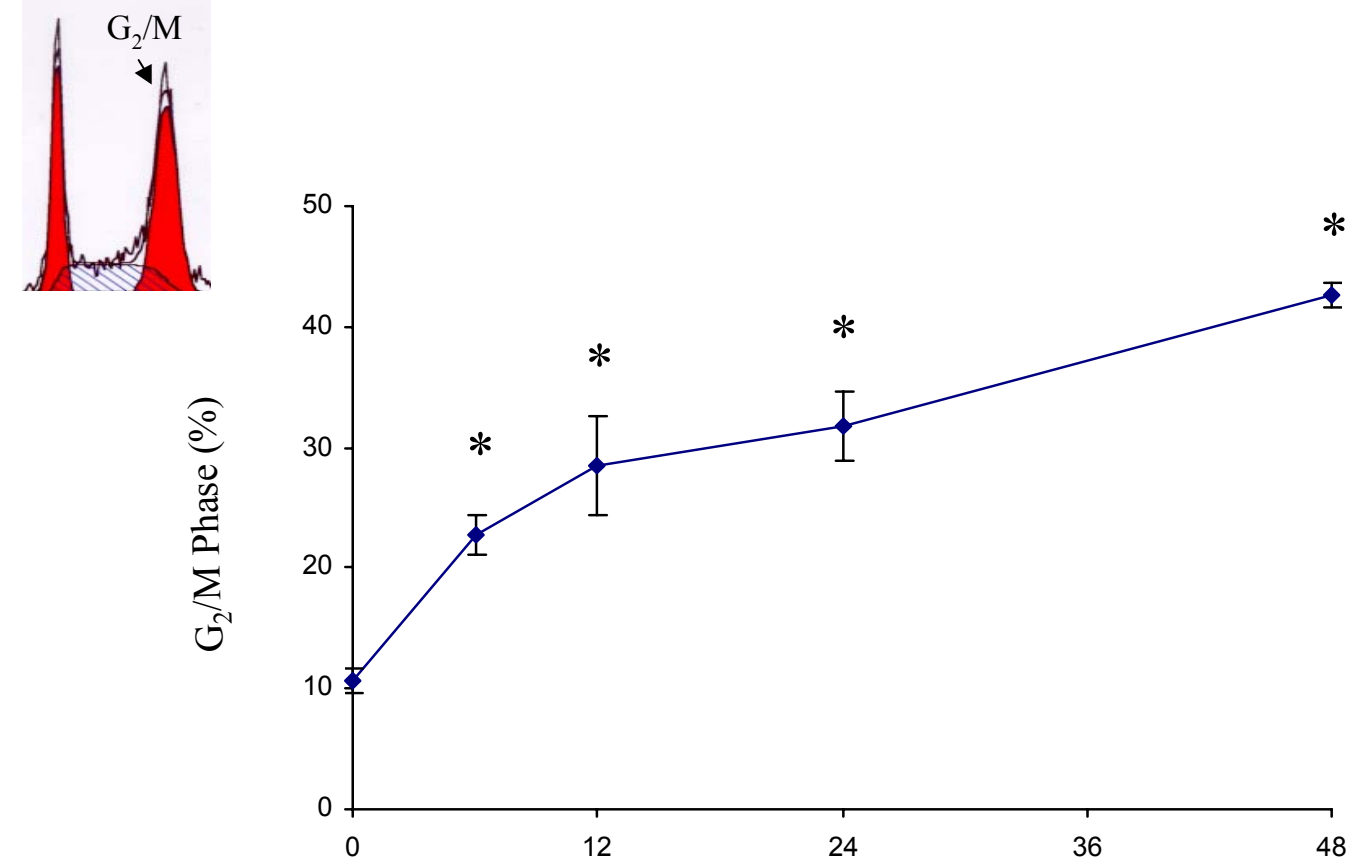

Time (h)

Figure 1 Vanadate-induced cell growth arrest. A549 cells were suspended in F12 K nutrient mixture medium containing $10 \%$ fetal bovine serum (FBS) in a 100 $\mathrm{mm}$ dish. After reaching 80-90\% confluence, cells were washed with PBS three times, and treated with $100 \mu \mathrm{M}$ vanadate for different times (A). Cells were harvested, and DNA content was measured by flow cytometry. Each point represents mean \pm SD of the percentage of S phase of three independent experiments. *, $\mathrm{p}<0.05$ compared to control (one-way ANOVA with Scheffe's test). 


\section{B}

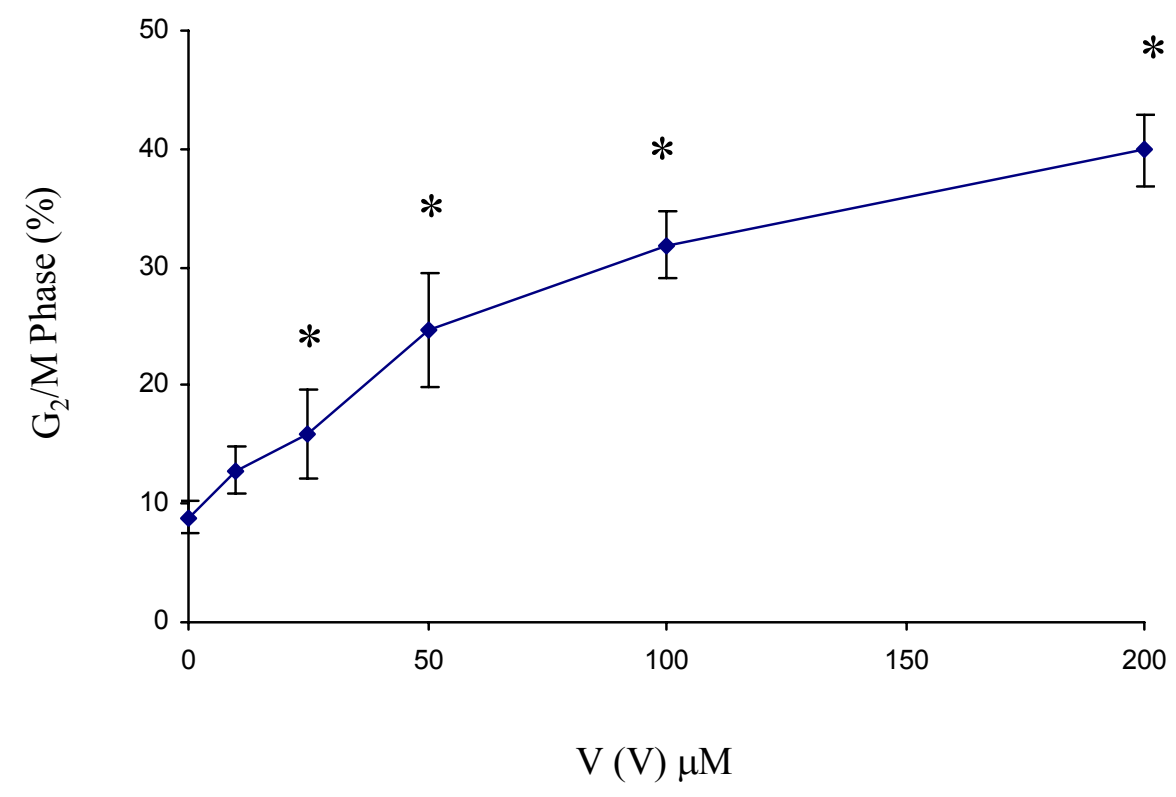

Figure 1 Vanadate-induced cell growth arrest. A549 cells were suspended in F12 K nutrient mixture medium containing 10\% fetal bovine serum (FBS) in a 100 mm dish. After reaching 80-90\% confluence, cells were washed with PBS three times, and treated with different doses for $24 \mathrm{~h}$. Cells were harvested, and DNA content was measured by flow cytometry. Each point represents mean $\pm \mathrm{SD}$ of the percentage of $\mathrm{S}$ phase of three independent experiments. *, $\mathrm{p}<0.05$ compared to control (one-way ANOVA with Scheffe's test). 


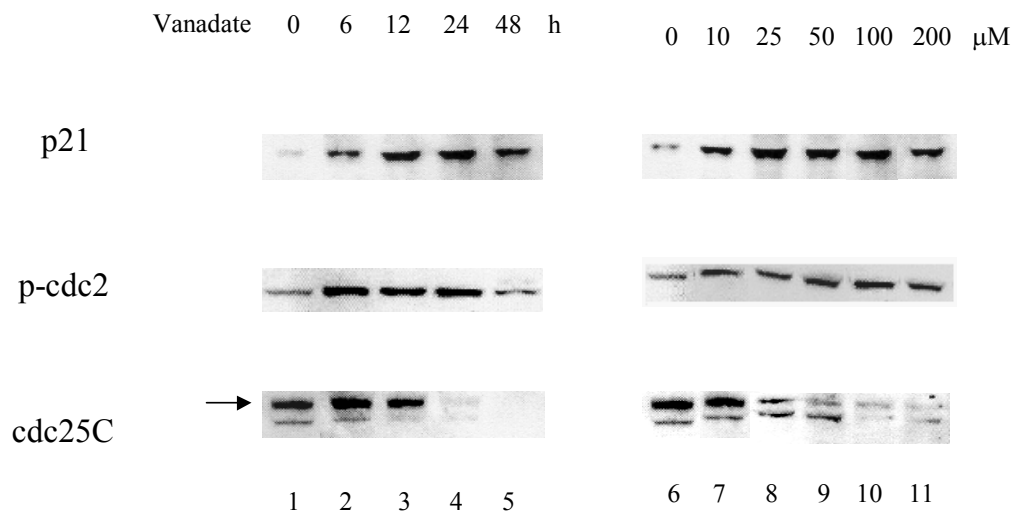

Figure 2 Effects of vanadate on cell growth regulatory proteins. A549 cells were incubated in a 6-well plate until $80-90 \%$ confluent. After washing with PBS three times, cells were treated with $100 \mu \mathrm{M}$ vanadate for different times or with different concentrations of vanadate for $24 \mathrm{~h}$. The whole cell lysates were collected for Western blotting using specific antibodies to p21, $\operatorname{cdc} 25 \mathrm{C}$, and phospho-cdc2 ${ }^{\mathrm{Tyr} 15}$. Left panel, time dependence. Lane 1, control without vanadate; lane 2, $6 \mathrm{~h}$; lane 3, $12 \mathrm{~h}$; lane 4, $24 \mathrm{~h}$; and lane 5, $48 \mathrm{~h}$. The concentration of vanadate was $100 \mu \mathrm{M}$. Right panel, concentration dependence. Lane 6, control without vanadate; lane 7, $10 \mu \mathrm{M}$; lane 8, 25 $\mu \mathrm{M}$; lane 9, $50 \mu \mathrm{M}$; lane 10, $100 \mu \mathrm{M}$; and lane 11, $200 \mu \mathrm{M}$. The incubation time was $24 \mathrm{~h}$. Data are from a single preparation representative of three independent experiments. 


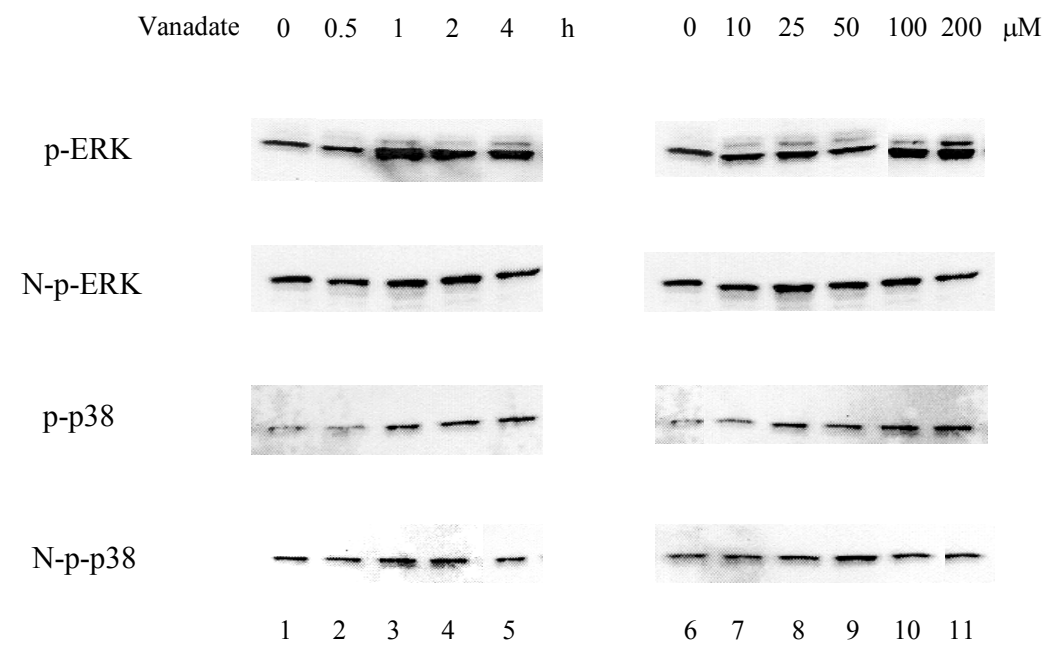

Figure 3 Vanadate-induced phosphorylation of ERK and p38. A549 cells were seeded in 6-well plates. The cells were treated with $100 \mu \mathrm{M}$ vanadate for $0.5 \mathrm{~h}$ to $4 \mathrm{~h}$ or with different doses of vanadate for $4 \mathrm{~h}$. Western blotting was performed as described in Figure 2. Left panel, time dependence. Lane 1, control without vanadate; lane $2,0.5 \mathrm{~h}$; lane $3,1 \mathrm{~h}$; lane $4,2 \mathrm{~h}$; and lane $5,4 \mathrm{~h}$. The concentration of vanadate was $100 \mu \mathrm{M}$. Right panel, concentration dependence. Lane 6, control without vanadate; lane 7, $10 \mu \mathrm{M}$; lane 8, $25 \mu \mathrm{M}$; lane 9, $50 \mu \mathrm{M}$; lane 10,100 $\mu \mathrm{M}$; and lane 11, $200 \mu \mathrm{M}$. The designations, $\mathrm{p}$ and $\mathrm{N}-\mathrm{p}$, represent the phosphorylated and non-phosphorylated form of the MAPKs. Data are from a single preparation representative of three independent experiments. 


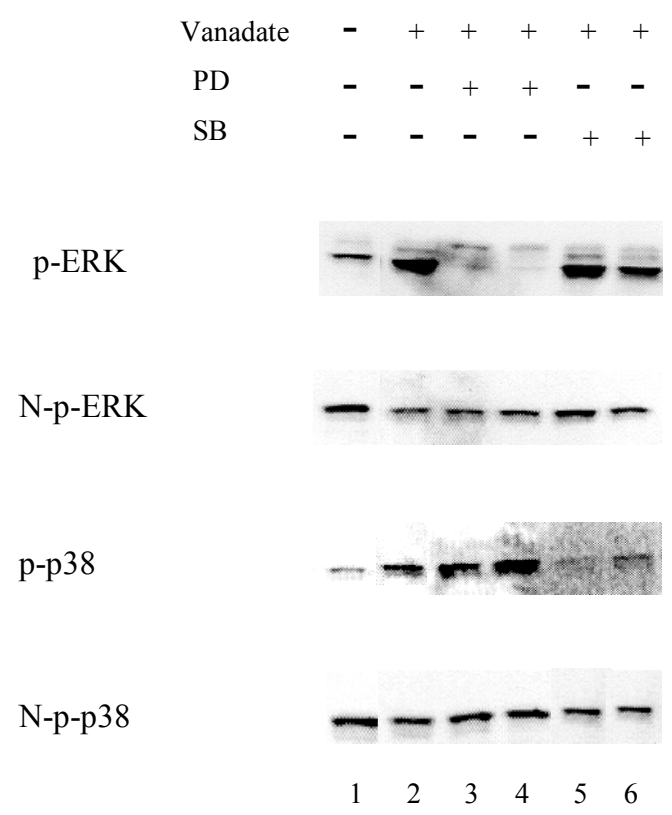

Figure 4 Inhibitory effects of ERK and p38 inhibitors on vanadate-induced activation ERK and p38. Western blotting was conducted as described in Figure 2. A549 cells were pretreated with PD 98059 and SB 202190 for $0.5 \mathrm{~h}$ before vanadate treatment $(100 \mu \mathrm{M}, 4 \mathrm{~h})$. Lane 1, control without vanadate; lane 2, vanadate; lane 3, vanadate $+50 \mu \mathrm{M}$ PD; lane 4 , vanadate $+100 \mu \mathrm{M}$ PD; lane 5, vanadate $+5 \mu \mathrm{M} \mathrm{SB}$; and lane 6 , vanadate $+10 \mu \mathrm{M} \mathrm{SB}$. The designations, $\mathrm{p}$ and N-p, represent the phosphorylated and non-phosphorylated form of the MAPKs. Data are from a single preparation representative of three independent experiments. 


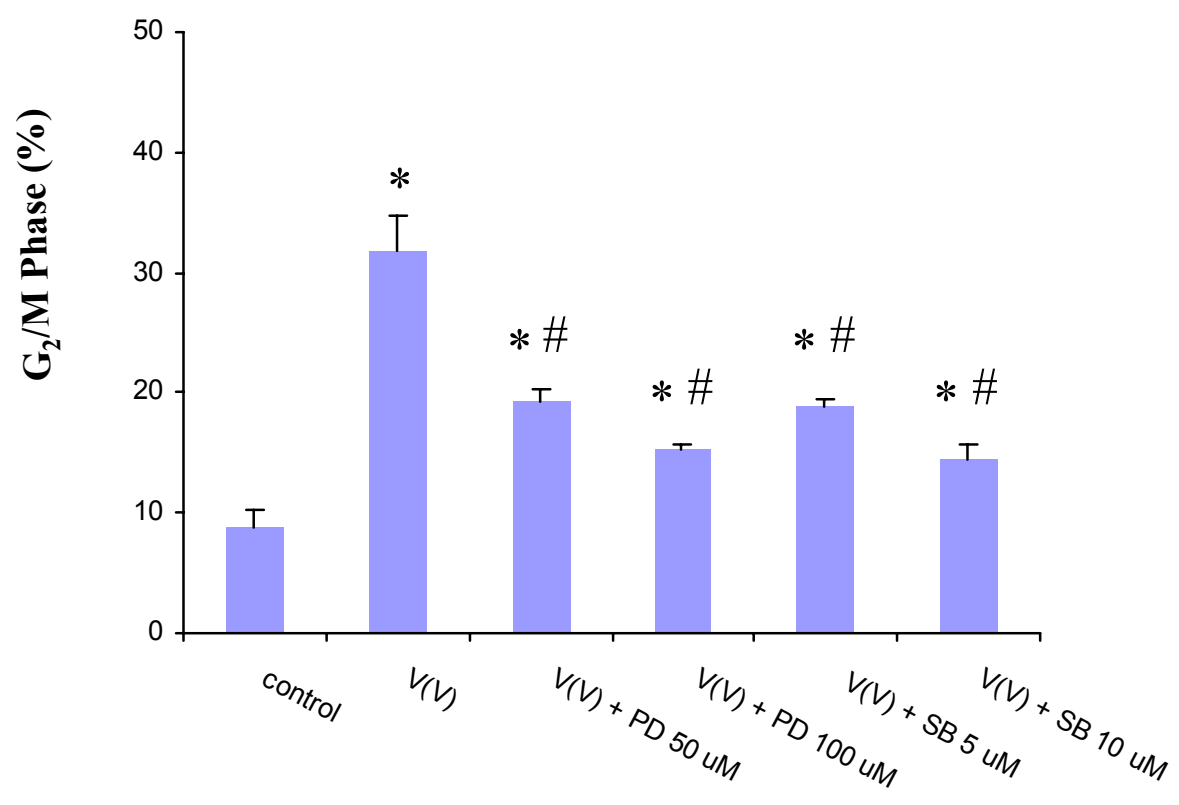

Figure 5 Inhibitory effects of ERK and p38 inhibitors on vanadate-induced cell growth arrest. A549 cells were incubated in a $100 \mathrm{~mm}$ dish and pretreated with eithor PD 98059 (an ERK inhibitor) or SB 202190 (a p38 kinase inhibitor) for $0.5 \mathrm{~h}$ prior to vanadate treatment $(100 \mu \mathrm{M})$ for $24 \mathrm{~h}$. Cell growth arrest was analyzed by DNA content using flow cytometry as described in Figure 1. a, control; b, vanadate; c, vanadate + $50 \mu \mathrm{M}$ PD98059; d, vanadate + $100 \mu \mathrm{M}$ PD98059; e, vanadate + $5 \mu \mathrm{M}$ SB202190; f, vanadate + $10 \mu \mathrm{M}$ SB202190. Each point represents mean $\pm \mathrm{SD}$ of the percentage of $\mathrm{S}$ phase of three independent experiments. ${ }^{*}, \mathrm{p}<0.05$ compared to control (one-way ANOVA with Scheffe's test). 


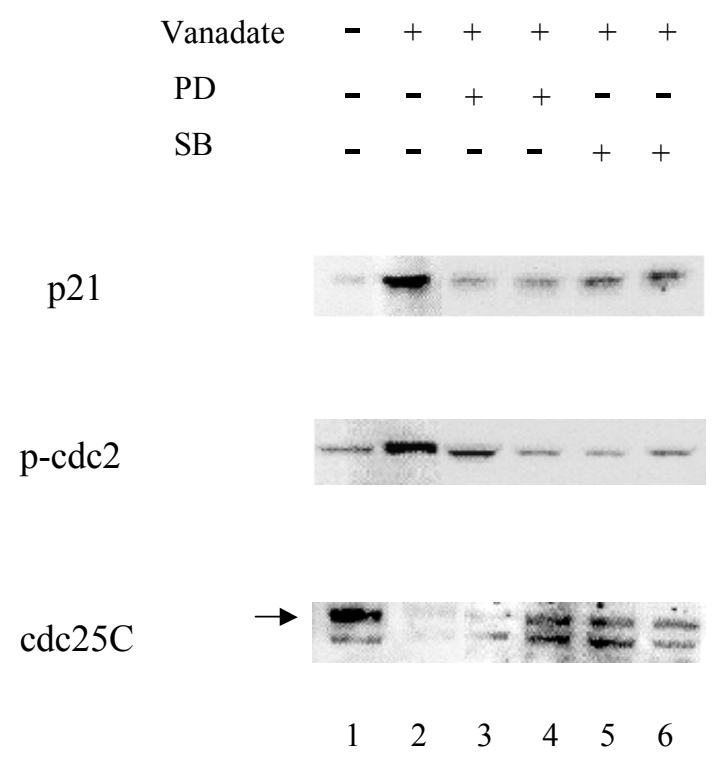

Figure 6 Effects of ERK and p38 inhibitors on vanadate-regulated cell growth regulatory proteins. The cells were pretreated with PD 98059 or SB 202190 for $0.5 \mathrm{~h}$ prior to vanadate treatment $(100 \mu \mathrm{M}, 24 \mathrm{~h})$. Proteins $\mathrm{p} 21$, phospho-cdc2 and cdc25C were analyzed using Western blotting. Lane 1, control without vanadate; lane 2, vanadate; lane 3, vanadate $+50 \mu \mathrm{M} \mathrm{PD}$; lane 4 , vanadate $+100 \mu \mathrm{M}$ PD; lane 5 , vanadate $+5 \mu \mathrm{M} \mathrm{SB}$; and lane 6 , vanadate $+10 \mu \mathrm{M}$ SB. Data are from a single preparation representative of three independent experiments. 
a

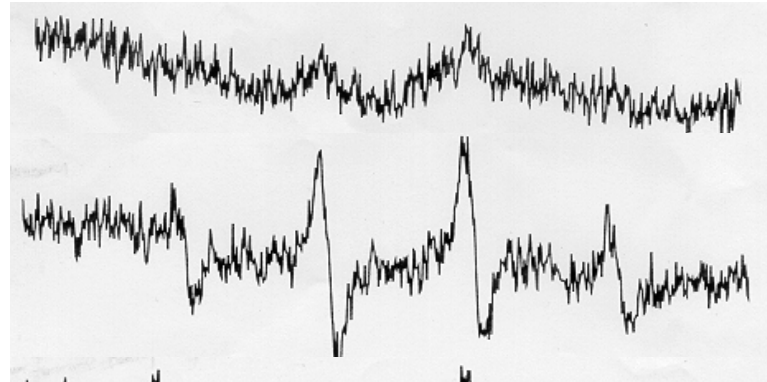

c
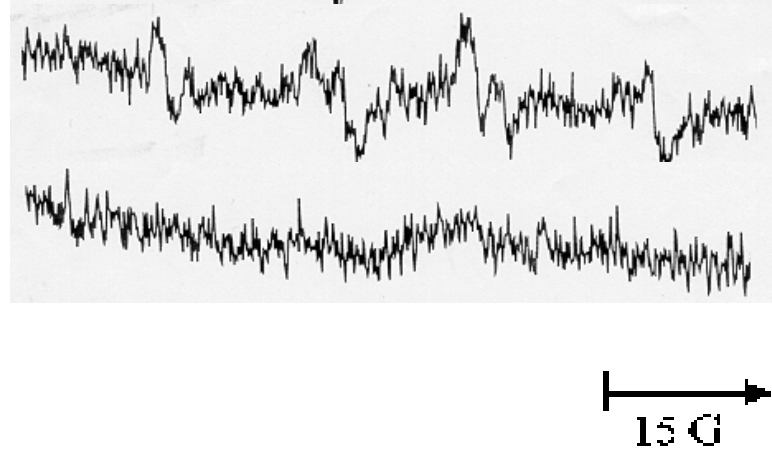

Figure 7 Hydroxyl radical formation induced by vanadate and the effects of antioxidants. $1 \times 10^{6}$ cells were mixed with $100 \mathrm{mM}$ DMPO and vanadate with or without antioxidants, sodium formate or catalase. ESR spectra were recorded for 6 min. a, cells only; b, cells + vanadate; c, cells + vanadate + sodium formate; and $\mathrm{d}$, cells + vanadate + catalase. The final concentrations were: vanadate, $100 \mu \mathrm{M}$; sodium formate, $100 \mathrm{mM}$; and catalase, 2,000 U/ml. Data are from a single preparation representative of three independent experiments. 
A

a

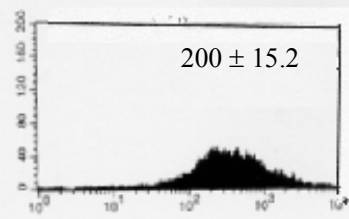

c

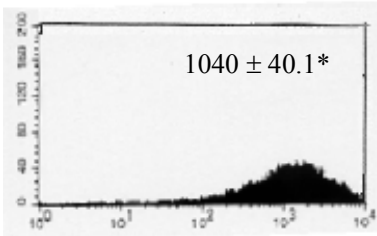

e b

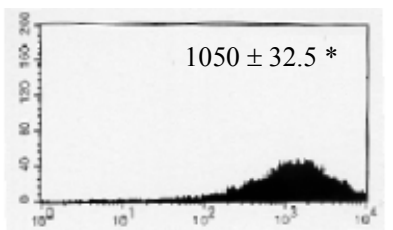

d

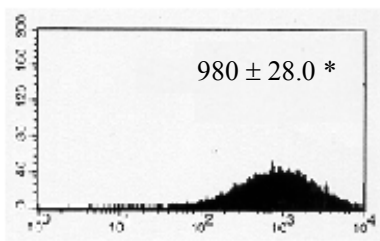

Figure 8 Formation of $\mathrm{H}_{2} \mathrm{O}_{2}$ and $\mathrm{O}_{2}{ }^{-}$induced by vanadate and the effects of antioxidants detected by flow cytometry. Cells were cultured in a 6-well plate. After reaching $80-90 \%$ confluence, cells were treated $100 \mu \mathrm{M}$ vanadate for $1 \mathrm{~h}$. For evaluation of antioxidant effects, the cells were pretreated with $500 \mathrm{U} / \mathrm{ml} \mathrm{SOD,} 300 \mu \mathrm{M}$ sodium formate or $5,000 \mathrm{U} / \mathrm{ml}$ catalase for $0.5 \mathrm{~h}$ before treatment with $100 \mu \mathrm{M}$ vanadate. DCFH-DA was added to the cells and incubated for another $15-20 \mathrm{~min}$ at $37^{\circ} \mathrm{C}$. Then the cells were washed with PBS twice and collected for analysis using flow cytometry. Panel A represents $\mathrm{H}_{2} \mathrm{O}_{2}$ signals. a, control; b, vanadate; c, vanadate + SOD; $d$, vanadate + sodium formate; and e, vanadate + catalase. Each point represents mean \pm SD of the percentage of $S$ phase of three independent experiments. *, \# indicate $\mathrm{p}<0.05$ compared to control and vanadate treatment, respectively (one-way ANOVA with Scheffe's test). 
a

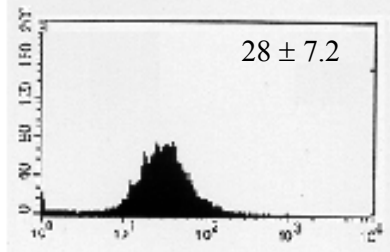

c

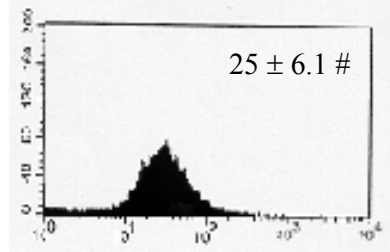

e

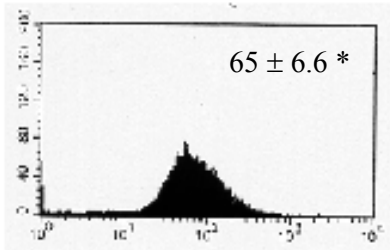

b

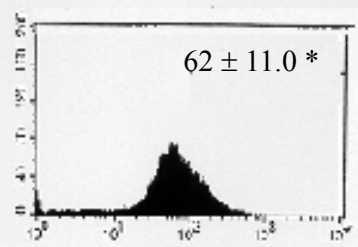

d

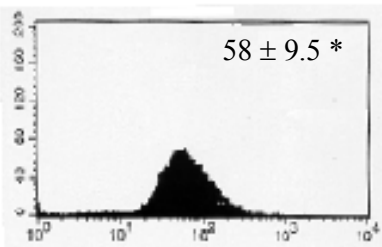

Figure 8 Formation of $\mathrm{H}_{2} \mathrm{O}_{2}$ and $\mathrm{O}_{2}{ }^{-}$induced by vanadate and the effects of antioxidants detected by flow cytometry. Cells were cultured in a 6-well plate. After reaching $80-90 \%$ confluence, cells were treated $100 \mu \mathrm{M}$ vanadate for $1 \mathrm{~h}$. For evaluation of antioxidant effects, the cells were pretreated with $500 \mathrm{U} / \mathrm{ml} \mathrm{SOD,} 300 \mu \mathrm{M}$ sodium formate or $5,000 \mathrm{U} / \mathrm{ml}$ catalase for $0.5 \mathrm{~h}$ before treatment with $100 \mu \mathrm{M}$ vanadate. HE was added to the cells and incubated for another $15-20 \mathrm{~min}$ at $37^{\circ} \mathrm{C}$. Then the cells were washed with PBS twice and collected for analysis using flow cytometry. Panel B represents $\mathrm{O}_{2}{ }^{\circ-}$ signals. a, control; b, vanadate; c, vanadate + SOD; d, vanadate + sodium formate; and e, vanadate + catalase. Each point represents mean $\pm \mathrm{SD}$ of the percentage of $\mathrm{S}$ phase of three independent experiments. *, \# indicate $\mathrm{p}<0.05$ compared to control and vanadate treatment, respectively (one-way ANOVA with Scheffe's test). 
A

TRITC

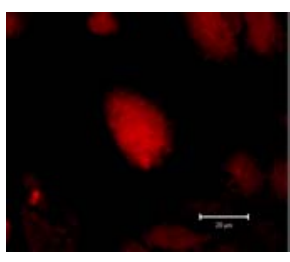

b
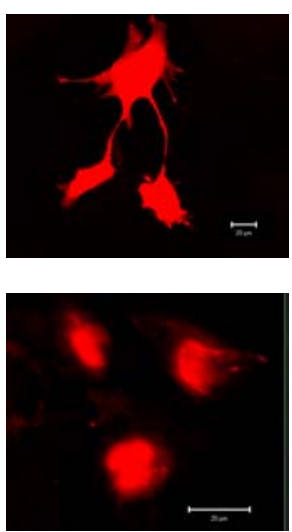

DCFH-DA
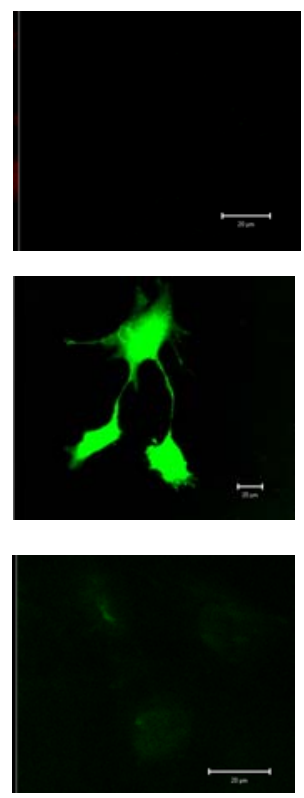

Figure 9 Formation of $\mathrm{H}_{2} \mathrm{O}_{2}$ and $\mathrm{O}_{2}{ }^{-*}$ induced by vanadate and the effects of antioxidants detected by confocal microscopy. The experimental conditions were the same as those described in Figure 8. TRITC was added together with DCFH-DA. TRITC was used as another dye to observe the presence of the cells because DCFH-DA is colorless unless it is oxidized by $\mathrm{H}_{2} \mathrm{O}_{2}$. Confocal microscopy was used to detect the generation of $\mathrm{H}_{2} \mathrm{O}_{2}$. Panel A represents the generation of $\mathrm{H}_{2} \mathrm{O}_{2}$. a, control; b, vanadate; and c, vanadate + catalase. Data are from a single preparation representative of three independent experiments. 
B

a
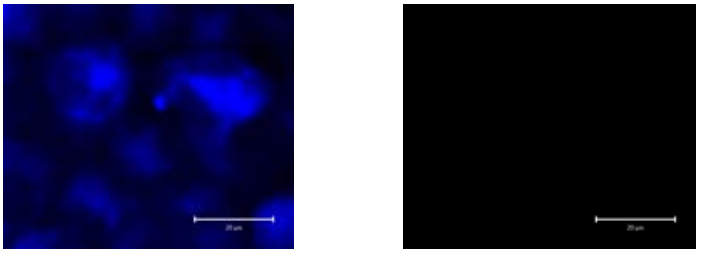

b
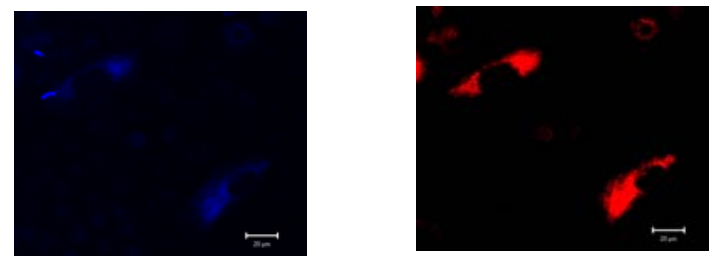

$\mathrm{c}$
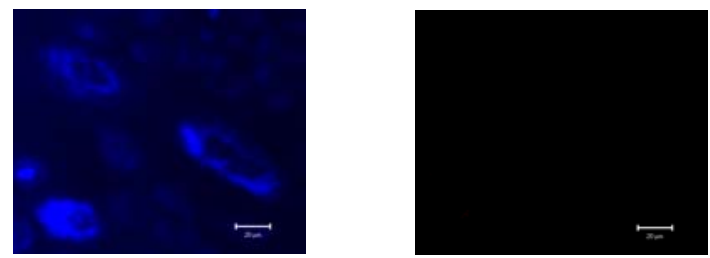

Figure 9 Formation of $\mathrm{H}_{2} \mathrm{O}_{2}$ and $\mathrm{O}_{2}{ }^{\bullet-}$ induced by vanadate and the effects of antioxidants detected by confocal microscopy. The experimental conditions were the same as those described in Figure 8. TRITC was added together with DCFH-DA. TRITC was used as another dye to observe the presence of the cells because DCFH-DA is colorless unless it is oxidized by $\mathrm{H}_{2} \mathrm{O}_{2}$. Confocal microscopy was used to detect the generation of $\mathrm{O}_{2}{ }^{\bullet}$. Panel $\mathrm{B}$ represents the generation of $\mathrm{O}_{2}{ }^{\bullet-}$. a, control; b, vanadate; and c, vanadate + SOD. Data are from a single preparation representative of three independent experiments. 


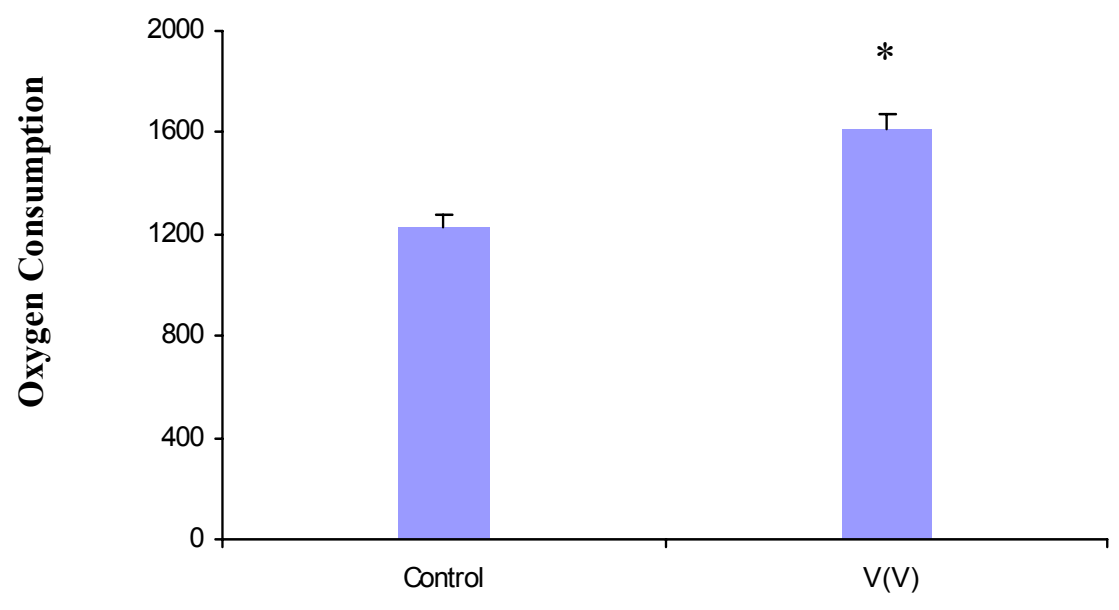

Figure 10 Measurement of oxygen consumption. $1 \times 10^{6}$ cells were prepared for detection of oxygen consumption using oxygraph. The final concentration of vanadate was $100 \mu \mathrm{M}$. Each point represents mean $\pm \mathrm{SD}$ of the percentage of S phase of three independent experiments. ${ }^{*}$ indicates $\mathrm{p}<0.05$ compared to control (one-way ANOVA with Scheffe's test). 


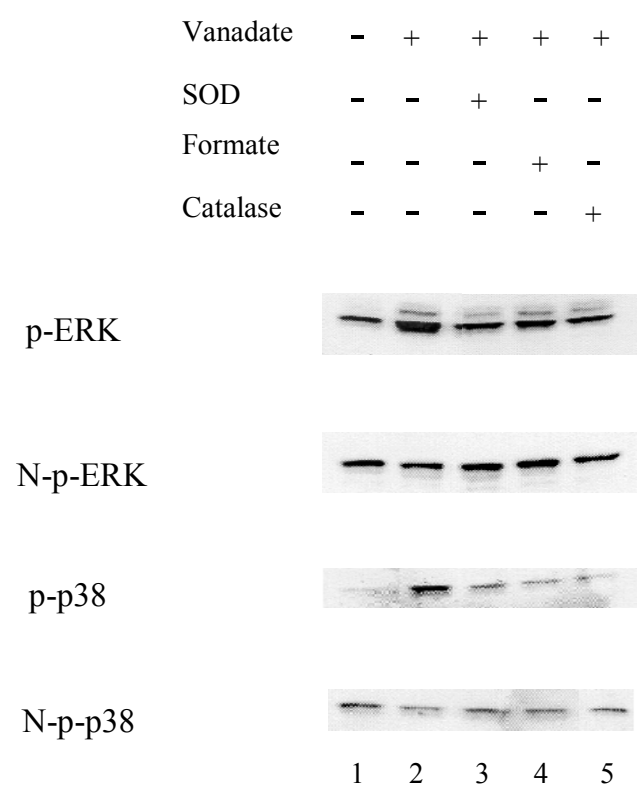

Figure 11 Effects of antioxidants on vanadate-activated ERK and p38. A549 cells were seeded in 6-well plate and pretreated with $500 \mathrm{U} / \mathrm{ml} \mathrm{SOD}, 300 \mu \mathrm{M}$ sodium formate or $5,000 \mathrm{U} / \mathrm{ml}$ catalase for $0.5 \mathrm{~h}$ before treatment with vanadate $(100$ $\mu \mathrm{M})$. After $4 \mathrm{~h}$, cells were harvested, and Western blotting was used to analyze phosphorylation of ERK and p38. Lane 1, control; lane 2, vanadate; lane 3, vanadate + SOD; lane 4, vanadate + sodium formate; and lane 5, vanadate + catalase. The designations, $\mathrm{p}$ and $\mathrm{N}-\mathrm{p}$, represent the phosphorylated and non-phosphorylated form of the MAKPs. Data are from a single preparation representative of three independent experiments. 


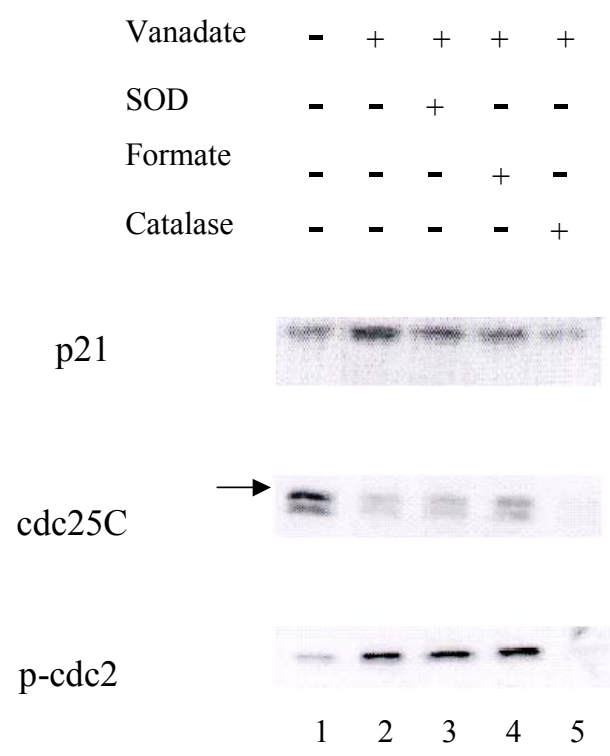

Figure 12 Effects of antioxidants on vanadate regulated cell growth regulatory proteins. A549 cells were incubated in a 6-well plate and pretreated with SOD, sodium formate or catalase for $0.5 \mathrm{~h}$ before treatment with vanadate $(100 \mu \mathrm{M})$. After $24 \mathrm{~h}$, cells were collected for Western blotting using specific antibodies to p21, cdc25C, and phospho-cdc $2^{\text {Tyr15 }}$. Lane 1, control; lane 2, vanadate; lane 3, vanadate + SOD; lane 4, vanadate + sodium formate; and lane 5, vanadate + catalase. Data are from a single preparation representative of three independent experiments. 


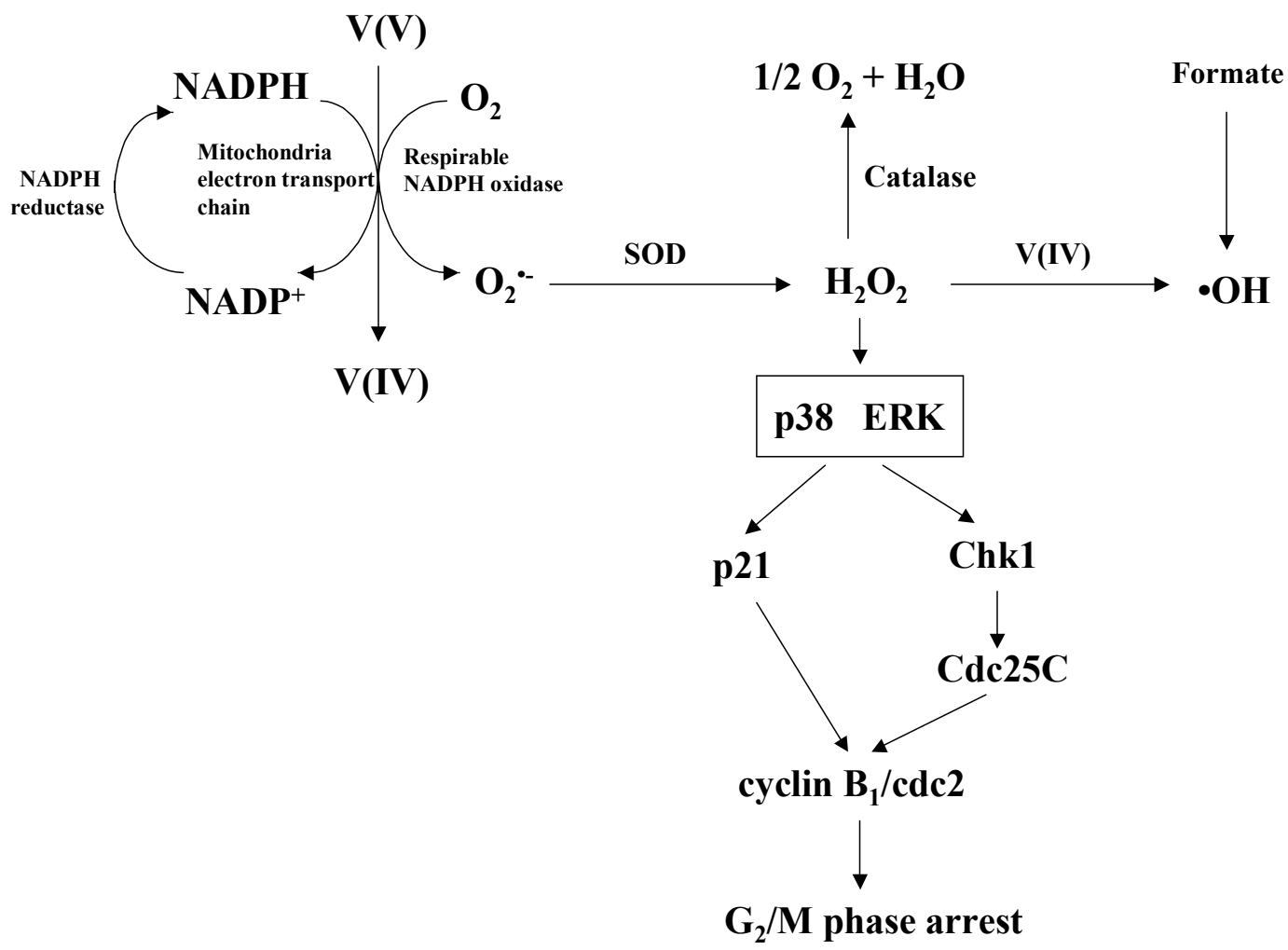

Figure 13 Schematic representation of possible mechanisms of vanadate (V)-induced cell growth arrest and its regulation via generation of $\mathrm{H}_{2} \mathrm{O}_{2}$ in $\mathrm{A} 549$ cells 


\section{I.7. REFERENCES}

1. Chasteen, N.D. (1983) The Biochemistry of vanadium. Struct Bond, 53, 107-137.

2. Kustin, K., McLeod, G., Gilbert, T.R., Briggs, L.B.R. (1983) Vanadium and other metal ions in the physiological ecilogy of marine organisms. Struc Bond, 53, 139185.

3. Nriagu, J.O. and Pacyna J.M. (1988) Quantitative assessment of worldwide contamination of air, water and soils by trace metals. Nature, 333, 134-9.

4. Boyd, D.W. and Kustin K. (1984) Vanadium: a versatile biochemical effector with an elusive biological function. Adv Inorg Biochem, 6, 311-65.

5. Erdmann, E., Werdan K., Krawietz W., Schmitz W. and Scholz H. (1984) Vanadate and its significance in biochemistry and pharmacology. Biochem Pharmacol, 33, 945-50.

6. Leonard, A. and Gerber G.B. (1994) Mutagenicity, carcinogenicity and teratogenicity of vanadium compounds. Mutat Res, 317, 81-8.

7. Younes, M. and Strubelt O. (1991) Vanadate-induced toxicity towards isolated perfused rat livers: the role of lipid peroxidation. Toxicology, 66, 63-74.

8. Zhong, B.Z., Gu Z.W., Wallace W.E., Whong W.Z. and Ong T. (1994) Genotoxicity of vanadium pentoxide in Chinese hamster V79 cells. Mutat Res, 321, 35-42.

9. Ramasarma, T. and Crane F.L. (1981) Does vanadium play a role in cellular regulation? Curr Top Cell Regul, 20, 247-301.

10. Stern, A., Yin X., Tsang S.S., Davison A. and Moon J. (1993) Vanadium as a modulator of cellular regulatory cascades and oncogene expression. Biochem Cell Biol, 71, 103-12.

11. Yin, X., Davison A.J. and Tsang S.S. (1992) Vanadate-induced gene expression in mouse C127 cells: roles of oxygen derived active species. Mol Cell Biochem, 115, 85-96. 
12. Hickey, R.J., Schoff E.P. and Clelland R.C. (1967) Relationship between air pollution and certain chronic disease death rates. Multivariate statistical studies. Arch Environ Health, 15, 728-38.

13. Stock, P. (1965) On the relations between atmospheric pollution in urban and rural location and mortality from cancer, bronchitis, pneumonia, with particular reference to 3,4-benzopyrene, beryllium, molybdenum, vanadium and arsenic. $\mathrm{Br}$ J Cancer, 14, 397-418.

14. Carpenter, G. (1981) Vanadate, epidermal growth factor and the stimulation of DNA synthesis. Biochem Biophys Res Commun, 102, 1115-21.

15. Hori, C.a.O., T. (1987) Vanadate enhances the stimulatory action of insurin on DNA synthesis in cultured mouse mammary glands. Biochim Biophys Acta, 610, $235-240$.

16. Sabbioni, E., Pozzi G., Pintar A., Casella L. and Garattini S. (1991) Cellular retention, cytotoxicity and morphological transformation by vanadium(IV) and vanadium(V) in BALB/3T3 cell lines. Carcinogenesis, 12, 47-52.

17. Nechay, B.R., Nanninga L.B. and Nechay P.S. (1986) Vanadyl (IV) and vanadate (V) binding to selected endogenous phosphate, carboxyl, and amino ligands; calculations of cellular vanadium species distribution. Arch Biochem Biophys, 251, 128-38.

18. Ding, M., Shi X., Dong Z., Chen F., Lu Y., Castranova V. and Vallyathan V. (1999) Freshly fractured crystalline silica induces activator protein-1 activation through ERKs and p38 MAPK. J Biol Chem, 274, 30611-6.

19. Carmichael, A.J. (1990) Vanadyl-induced Fenton-like reaction in RNA. An ESR and spin trapping study. FEBS Lett, 261, 165-70.

20. Carmichael, A.J. (1990) Reaction of vanadyl with hydrogen peroxide. An ESR and spin trapping study. Free Radic Res Commun, 10, 37-45.

21. Huang, C., Ding M., Li J., Leonard S.S., Rojanasakul Y., Castranova V., Vallyathan V., Ju G. and Shi X. (2001) Vanadium-induced nuclear factor of 
activated T cells activation through hydrogen peroxide. J Biol Chem, 276, 22397403.

22. Keller, R.J., Sharma R.P., Grover T.A. and Piette L.H. (1988) Vanadium and lipid peroxidation: evidence for involvement of vanadyl and hydroxyl radical. Arch Biochem Biophys, 265, 524-33.

23. Ozawa, T., Hanaki, A. (1989) ESR evidence for the formarion of hydroxyl radicals during the reaction of vanadyl ions with hydrogen peroxide. Chem Pharm Bull, 37, 1407-1409.

24. Shi, X.L. and Dalal N.S. (1990) Glutathione reductase functions as vanadate(V) reductase. Arch Biochem Biophys, 278, 288-90.

25. Shi, X.L. and Dalal N.S. (1991) Flavoenzymes reduce vanadium(V) and molecular oxygen and generate hydroxyl radical. Arch Biochem Biophys, 289, $355-61$.

26. Shi, X., Wang P., Jiang H., Mao Y., Ahmed N. and Dalal N. (1996) Vanadium(IV) causes 2'-deoxyguanosine hydroxylation and deoxyribonucleic acid damage via free radical reactions. Ann Clin Lab Sci, 26, 39-49.

27. Ye, J., Ding M., Leonard S.S., Robinson V.A., Millecchia L., Zhang X., Castranova V., Vallyathan V. and Shi X. (1999) Vanadate induces apoptosis in epidermal JB6 $\mathrm{P}+$ cells via hydrogen peroxide-mediated reactions. Mol Cell Biochem, 202, 9-17.

28. Huang, C., Zhang Z., Ding M., Li J., Ye J., Leonard S.S., Shen H.M., Butterworth L., Lu Y., Costa M., Rojanasakul Y., Castranova V., Vallyathan V. and Shi X. (2000) Vanadate induces p53 transactivation through hydrogen peroxide and causes apoptosis. J Biol Chem, 275, 32516-22.

29. Ding, M., Li J.J., Leonard S.S., Ye J.P., Shi X., Colburn N.H., Castranova V. and Vallyathan V. (1999) Vanadate-induced activation of activator protein-1: role of reactive oxygen species. Carcinogenesis, 20, 663-8. 
30. Shackelford, R.E., Kaufmann W.K. and Paules R.S. (1999) Cell cycle control, checkpoint mechanisms, and genotoxic stress. Environ Health Perspect, 107 Suppl 1, 5-24.

31. Hartwell, L.H. and Weinert T.A. (1989) Checkpoints: controls that ensure the order of cell cycle events. Science, 246, 629-34.

32. Hartwell, L.H. and Kastan M.B. (1994) Cell cycle control and cancer. Science, 266, 1821-8.

33. Mercer, W.E. (1998) Checking on the cell cycle. J Cell Biochem Suppl, 31, 50-4.

34. Cheng, T.H., Shih N.L., Chen S.Y., Wang D.L. and Chen J.J. (1999) Reactive oxygen species modulate endothelin-I-induced c-fos gene expression in cardiomyocytes. Cardiovasc Res, 41, 654-62.

35. Schreck, R., Rieber P. and Baeuerle P.A. (1991) Reactive oxygen intermediates as apparently widely used messengers in the activation of the NF-kappa B transcription factor and HIV-1. EMBO J, 10, 2247-58.

36. Nakamura, K., Fushimi K., Kouchi H., Mihara K., Miyazaki M., Ohe T. and Namba M. (1998) Inhibitory effects of antioxidants on neonatal rat cardiac myocyte hypertrophy induced by tumor necrosis factor-alpha and angiotensin II. Circulation, 98, 794-9.

37. Lander, H.M. (1997) An essential role for free radicals and derived species in signal transduction. FASEB J, 11, 118-24.

38. Adler, V., Yin Z., Fuchs S.Y., Benezra M., Rosario L., Tew K.D., Pincus M.R., Sardana M., Henderson C.J., Wolf C.R., Davis R.J. and Ronai Z. (1999) Regulation of JNK signaling by GSTp. EMBO J, 18, 1321-34.

39. Kurata, S. (1996) Sensitization of the HIV-1-LTR upon long term low dose oxidative stress. J Biol Chem, 271, 21798-802.

40. Kyriakis, J.M., Banerjee P., Nikolakaki E., Dai T., Rubie E.A., Ahmad M.F., Avruch J. and Woodgett J.R. (1994) The stress-activated protein kinase subfamily of c-Jun kinases. Nature, 369, 156-60. 
41. Raingeaud, J., Gupta S., Rogers J.S., Dickens M., Han J., Ulevitch R.J. and Davis R.J. (1995) Pro-inflammatory cytokines and environmental stress cause p38 mitogen- activated protein kinase activation by dual phosphorylation on tyrosine and threonine. J Biol Chem, 270, 7420-6.

42. Stein, B., Brady H., Yang M.X., Young D.B. and Barbosa M.S. (1996) Cloning and characterization of MEK6, a novel member of the mitogen- activated protein kinase kinase cascade. J Biol Chem, 271, 11427-33.

43. Cohen, P. (1997) The search for physiological substances of MAP and SAP kinases in mammalian cells. Trends Cell Biol, 7, 353-361.

44. Fanger, G.R., Gerwins P., Widmann C., Jarpe M.B. and Johnson G.L. (1997) MEKKs, GCKs, MLKs, PAKs, TAKs, and tpls: upstream regulators of the c- Jun amino-terminal kinases? Curr Opin Genet Dev, 7, 67-74.

45. Herskowitz, I. (1995) MAP kinase pathways in yeast: for mating and more. Cell, 80, $187-97$.

46. Kurata, S. (2000) Selective activation of p38 MAPK cascade and mitotic arrest caused by low level oxidative stress. J Biol Chem, 275, 23413-6.

47. Takenaka, K., Moriguchi T. and Nishida E. (1998) Activation of the protein kinase p38 in the spindle assembly checkpoint and mitotic arrest. Science, 280, 599-602.

48. Su, B., Mitra S., Gregg H., Flavahan S., Chotani M.A., Clark K.R., GoldschmidtClermont P.J. and Flavahan N.A. (2001) Redox regulation of vascular smooth muscle cell differentiation. Circ Res, 89, 39-46.

49. Nicoletti, I., Migliorati, G., Pagliacci, M.C., Grignani, F. and Riccardi, C. (1991) A rapid and simple method for measuring thymocyte apoptosis by propidium iodide staining and flow cytometry. J Immunol Methods, 139, 271-279.

50. Sgonic, R.a.W., G (1994.) Methods for the detection of apoptosis. Int Arch Allergy Immunol, 105, 327-332.

51. Rosen, G.M., Finkelstein, E. (1985) Use of spin traps in biological systems. $A d v$ Free Radical Biol Med, 1, 345-375. 
52. Shi, X.L. and Dalal N.S. (1989) Chromium (V) and hydroxyl radical formation during the glutathione reductase-catalyzed reduction of chromium (VI). Biochem Biophys Res Commun, 163, 627-34.

53. Shi, X. and Dalal N.S. (1992) Hydroxyl radical generation in the NADH/microsomal reduction of vanadate. Free Radic Res Commun, 17, 369-76.

54. Bass, D.A., Parce J.W., Dechatelet L.R., Szejda P., Seeds M.C. and Thomas M. (1983) Flow cytometric studies of oxidative product formation by neutrophils: a graded response to membrane stimulation. J Immunol, 130, 1910-7.

55. LeBel, C.P., Ischiropoulos H. and Bondy S.C. (1992) Evaluation of the probe $2^{\prime}, 7^{\prime}$-dichlorofluorescin as an indicator of reactive oxygen species formation and oxidative stress. Chem Res Toxicol, 5, 227-31.

56. Kahn, E., Frouin F., Souchier C., Bernengo J.C., Bruzzoni-Giovanelli H., Clement O., Frija G., Di Paola R., Calvo F. and Linares-Cruz G. (2000) Confocal multilaser focusing and single-laser characterization of ultraviolet excitable stains of cellular preparations. Cytometry, 40, 42-9.

57. Kastan, M.B. (2001) Cell cycle. Checking two steps. Nature, 410, 766-7.

58. Zhang, Z., Huang C., Li J., Leonard S.S., Lanciotti R., Butterworth L. and Shi X. (2001) Vanadate-induced cell growth regulation and the role of reactive oxygen species. Arch Biochem Biophys, 392, 311-20.

59. Ono, K. and Han J. (2000) The p38 signal transduction pathway: activation and function. Cell Signal, 12, 1-13.

60. Tibbles, L.A. and Woodgett J.R. (1999) The stress-activated protein kinase pathways. Cell Mol Life Sci, 55, 1230-54.

61. Wilkinson, M.G. and Millar J.B. (2000) Control of the eukaryotic cell cycle by MAP kinase signaling pathways. FASEB J, 14, 2147-57.

62. Dobrowolski, S., Harter M. and Stacey D.W. (1994) Cellular ras activity is required for passage through multiple points of the G0/G1 phase in BALB/c 3T3 cells. Mol Cell Biol, 14, 5441-9. 
63. Winston, J.T., Coats S.R., Wang Y.Z. and Pledger W.J. (1996) Regulation of the cell cycle machinery by oncogenic ras. Oncogene, 12, 127-34.

64. Kosako, H., Gotoh Y. and Nishida E. (1994) Requirement for the MAP kinase kinase/MAP kinase cascade in Xenopus oocyte maturation. EMBO J, 13, 2131-8.

65. Bitangcol, J.C., Chau A.S., Stadnick E., Lohka M.J., Dicken B. and Shibuya E.K. (1998) Activation of the p42 mitogen-activated protein kinase pathway inhibits Cdc2 activation and entry into M-phase in cycling Xenopus egg extracts. Mol Biol Cell, 9, 451-67.

66. Wright, J.H., Munar E., Jameson D.R., Andreassen P.R., Margolis R.L., Seger R. and Krebs E.G. (1999) Mitogen-activated protein kinase kinase activity is required for the $\mathrm{G}(2) / \mathrm{M}$ transition of the cell cycle in mammalian fibroblasts. Proc Natl Acad Sci U S A, 96, 11335-40.

67. Vallyathan, V. and Shi X. (1997) The role of oxygen free radicals in occupational and environmental lung diseases. Environ Health Perspect, 105 Suppl 1, 165-77. 


\section{SECTION II}

Vanadate-induced S phase Arrest is p53-dependent through Activation of p21 in C141 Cells 


\section{II.1. ABSTRACT}

Vanadium is widely used in industry. It is a potent toxic agent and carcinogen. The mechanisms involved in its toxicity and carcinogenesis are still unclear. An improper cell growth is believed to be involved in cancer development. The present study investigated the regulation of p53 on vanadate-induced cell growth arrest using both p53 wild type C141 cells and p53 deficient embryo fibroblasts (p53 -/-). On vanadate stimulation, C141 cells exhibited a dose- and time-dependent S phase arrest as determined by DNA content analysis. In contrast, vanadate was unable to increase the percentage of S phase in p53 -/- cells. Luciferase assay showed that vanadate induced p53 activation in a dose- and time-dependent manner in p53 wild type C141 cells. Addition of pifithrin- $\alpha$ (PFT), a specific inhibitor of p53, reduced the activation of p53 with a concomitant decrease in growth arrest at $\mathrm{S}$ phase. Western blotting analysis demonstrated that vanadate caused a dose- and time-dependent increase of p21 level in C141 cells. Pretreatment of C141 cells with PFT decreased p21 expression induced by vanadate while the p21 expression did not vary in vanadate stimulated p53 -/- cells. The results obtained from the present study suggest that vanadate is able to induce $\mathrm{S}$ phase arrest through p53 and p21-dependent pathway. 


\section{II.2. INTRODUCTION}

Vanadium exists in water, rocks, and soils in low concentrations and in coal and oil deposits in relatively high concentrations. Vanadium is widely used in mining, steel and steel-alloy making, and in chemical industry. Epidemiological studies have shown a correlation between vanadate exposure and the incidence of lung cancer $(1,2)$. Workers occupationally exposed to vanadium are at risk as respirable particulates may penetrate deeper into the tracheobronchial tree. Vanadium mimics the effect of insulin, and stimulates or inhibits several enzymes in vivo and in vitro. Many studies focus on mitogenic effects of vanadate, which is mediated by inhibiting the activity of tyrosine phosphatase and triggering the autophosphorylation of tyrosine kinase on cell membrane receptors (3). However, other mechanisms are plausible. For example, as a pro-oxidant, vanadate causes DNA damage, DNA strand breaks, and cell transformation $(4,5)$.

The ability of cells to maintain genomic integrity is vital for cell survival and proliferation. Lack of fidelity in DNA replication and maintenance can result in deleterious mutations leading to cell death or, in multicellular organisms, cancer (6). Minor cell damage is repaired by a temporary pause of cell cycle. If the damage is severe, cells will undergo apoptosis and enter into a dormant $\mathrm{G}_{0}$ state. Signal transduction pathways play a key role in the regulation of cell cycle progression and stabilization of DNA under genotoxic stress. It is known that signal transduction pathways control the activation of transcription factors and the regulation of gene expression as well as a temporary pause of cell progression to allow the damaged DNA to be repaired. The mechanisms involved in the regulations of vanadate on cell cycle control remain unknown.

The p53 tumor suppressor is a multifunctional protein that exerts a variety of different effects and plays a central role in the regulation of the normal cell cycle. A number of different stimuli are known to activate p53 (7). Overexpression of the p53 
protein was found to induce cell growth arrest associated with $G_{0} / G_{1}$ checkpoint (8-10) and to induce apoptosis that occurs either through the $\mathrm{G}_{0} / \mathrm{G}_{1}$ checkpoint or the $\mathrm{S}$ phase $(11,12)$, or cell differentiation. Overexpression of the $\mathrm{p} 53$ protein has also been suggested to be associated with $\mathrm{G}_{2} / \mathrm{M}$ checkpoint regulation $(13,14)$. Furthermore, p21 (WAF$1 / \mathrm{CIP} 1)$ is known to be a transactivation target of $\mathrm{p} 53$, and is believed to mediate $\mathrm{p} 53$ induced growth arrest triggered by DNA damage $(15,16)$. Induction of p21 expression could serve as an indicator for transactivation by $\mathrm{p} 53$, although $\mathrm{p} 21$ was also shown to be transactivated by p53-independent mechanisms (17).

The purpose of the present study was to identify the possible mechanisms of vanadate-induced cell growth arrest. The specific questions to be addressed were: 1) Does vanadate induce cell growth arrest? 2) If yes, does p53 play an important role? 3) What is the mechanism involved in p53 regulated cell growth arrest? 


\section{II.3. MATERIALS AND METHODS}

Reagents Sodium metavanadate was from Aldrich (Milwaukee, WI). RNase A, DMEM and EMEM medium were from Sigma (St. Louis, MO). Propidium iodide (PI) was from Molecular probes (Eugene, OR). Fetal bovine serum (FBS) was purchased from Gibco BRL (Life Technologies, Gaithersburg, MD). Pifithrin- $\alpha$ (PFT) was purchased from Alexis (San Diego, LA). Antibody to p21 was from Santa Cruz Biotechnology (Santa Cruz, CA). Secondary AP linked anti-rabbit IgG was from Cell Signaling (Beverly, MA).

Cell culture The JB6 $\mathrm{P}^{+}$mouse epidermal cell line, C141 and its stable p53 luciferase reporter plasmid transfectant, C141 p53 cells were cultured in MEM medium containing 5\% FBS, $2 \mathrm{mM}$ L-glutamine and $25 \mu \mathrm{g} / \mathrm{ml}$ gentamicin in an incubator at 5\% $\mathrm{CO}_{2}$ and $37^{\circ} \mathrm{C}$. p53-deficient embryo fibroblasts (p53-/-) derived from p53 gene knockout mice were incubated in DMEM medium with 10\% FBS, $2 \mathrm{mM}$ L-glutamine and $25 \mu \mathrm{g} / \mathrm{ml}$ gentamicin at $5 \% \mathrm{CO}_{2}$ and $37^{\circ} \mathrm{C}$.

Treatments For the time-course study, the cells were treated with $100 \mu \mathrm{M}$ vanadate for $6,12,24$, and $48 \mathrm{~h}$. For the dose-response study, the cells were treated with $10,25,50$, and $100 \mu \mathrm{M}$ vanadate for $24 \mathrm{~h}$. For the inhibitory studies of p53, the cells were pre-incubated with PFT for $0.5 \mathrm{~h}$ prior to the vanadate treatment.

Measurement of cell cycle/DNA content DNA content in S phase was analyzed using flow cytometry according to the methods described previously $(18,19)$. Cells were first fixed and permeabilized with 70\% ice-cold ethanol for more than $2 \mathrm{~h}$, followed by incubation with the freshly prepared staining buffer $(0.1 \%$ Triton X-100 in PBS, 200 $\mu \mathrm{g} / \mathrm{ml} \mathrm{RNase} \mathrm{A}$, and $20 \mu \mathrm{g} / \mathrm{ml} \mathrm{PI)} \mathrm{for} 30 \mathrm{~min}$ at room temperature. Cell cycle analysis was performed by flow cytometry with at least 10,000 cells for each sample. The DNA 
content histogram was abstracted and the percentage of cells in S phase was then calculated using ModFit LT software.

Luciferase assay for p53 activity After C141 p53 cells were 80-90\% confluent, $1 \times 10^{4}$ cells were added into 96-well plate with $100 \mu 1$ medium in each well. The cells were subjected to different treatments according to the experimental design. At various time points, the cells were extracted with lysis buffer. The p53 luciferase activity was measured using a luminometer (moonlight 3010). The results were expressed as p53 activity relative to the control.

Western blotting analysis Whole cell extracts were mixed with Tris-Glycine SDS sample buffer and then subjected to Tris-Glycine gel electrophoresis. The resolved proteins were transferred to a PVDF membrane. A Western blotting assay was performed using antibodies against p21 and secondary anti-rabbit IgG. After reaction with ECF substrate, the signal was detected using a Storm Scanner (Molecular Dynamics, Sunnyvale, CA).

Statistical analysis All data were based on at least three independent experiments. Cell growth arrest and relative p53 activity data were presented as means \pm SD and analyzed using one-way ANOVA with the Scheffe's test. A $p$ value less than 0.05 was considered statistically significant. 


\section{II.4 RESULTS}

The effects of vanadate in celll cycle in C141 cells and p53 -/- cells To study vanadate-induced cell growth arrest, DNA content was used to measure the percentage of different phases. Figure $1 \mathrm{~A}$ shows that the percentage of $\mathrm{S}$ phase increased with the increase in vanadate concentration up to $100 \mu \mathrm{M}$ in C141 cells. The percentage of S phase increased from $8 \%$ to $30 \%$ when vanadate concentration increased from 0 to 100 $\mu \mathrm{M}$. Figure 1B shows the results from time-dependent study of vanadate-induced cell growth arrest in C141 cells. Treatment of C141 cells with $50 \mu \mathrm{M}$ vanadate for $6 \mathrm{~h}$ did not significantly increase the $\mathrm{S}$ phase percentage compared to the control. However, the difference of S phase percentage increased between the treatment and the control with time in C141 cells (Figure 1B), being 12\%,19\% and 20\% when the cells were treated with $50 \mu \mathrm{M}$ vanadate for 12,24 and $48 \mathrm{~h}$, respectively. In p53 -/- cells, treatment with different concentrations of vanadate for $24 \mathrm{~h}$ did not cause any significant increase in $\mathrm{S}$ phase (Figure 2A). The S phase percentage was $20 \%$ and $16 \%$ in control cells and 100 $\mu \mathrm{M}$ vanadate stimulated cells, respectively (Figure $2 \mathrm{~A}$ ). There was no significant difference between the treatment of vanadate and the control in p53 -/- cells for incubation time up to $48 \mathrm{~h}$ (Figure 2B).

Vanadate-induced p53 activation Luciferase assay was used to measure the p53 activity in C141 cells. Vanadate treatment caused a dose-dependent increase in p53 activity (Figure 3A). Upon treatment with $10 \mu \mathrm{M}$ vanadate for $24 \mathrm{~h}$, the p53 activity increased 1.6-fold compared to the control. It was about 5.4-fold when cells were treated with $100 \mu \mathrm{M}$ vanadate. Vanadate also caused a time-dependent activation of p53 as shown in Figure 3B. The relative p53 activity increased from 1.4-fold to 5.3-fold when vanadate treatment time was increased from $6 \mathrm{~h}$ to $48 \mathrm{~h}$. 
The inhibition of vanadate-induced cell growth arrest PFT, a specific inhibitor of $\mathrm{p} 53$, was used to investigate the effect of $\mathrm{p} 53$ in vanadate-induced cell growth arrest in C141 cells. As shown in Figure 4, $50 \mu \mathrm{M}$ vanadate significantly increased the percentage of S phase. Pretreatment with $10 \mu \mathrm{M}$ or $20 \mu \mathrm{M}$ PFT for $0.5 \mathrm{~h}$ decreased the percentage of $\mathrm{S}$ phase to the control level.

The inhibition of vanadate-induced p53 activation To examine whether PFT is able to inhibit vanadate-induced p53 activation, the effect of PFT on p53 activity was measured. Figure 5 shows the results of inhibitory effect of PFT on vanadate-activated p53 in C141 cells using luciferase assay. Addition of PFT $(10 \mu \mathrm{M})$ to the stimulated cells significantly decreased the relative p53 activity induced by $50 \mu \mathrm{M}$ vanadate. An increase in PFT concentration $(20 \mu \mathrm{M})$ further attenuated the relative p53 activity.

The effects of vanadate on p21 activation and the role of p53 Western blotting was used to detect p21 protein level. Figure 6 shows that C141 cells treated with $50 \mu \mathrm{M}$ vanadate for 6-48 h displayed a time-dependent increase in p21 level (panel A). In contrast, p21 decreased when p53 deficient cells were treated with $50 \mu \mathrm{M}$ vanadate for 6 $\mathrm{h}$ and $12 \mathrm{~h}$ (panel B). In addition, vanadate activated p21 in a dose-dependent manner when the cells were treated with different concentrations of vanadate for $24 \mathrm{~h}$ (Figure 7, panel A). In p53 deficient cells, p21 remained the same level as the control when the cells were stimulated with 10, 25 and $50 \mu \mathrm{M}$ vanadate for $24 \mathrm{~h}$ (Figure 7, panel B). Expression of p21 decreased at $100 \mu \mathrm{M}$ vanadate treatment. Addition of PFT in stimulated C141 cells decreased the p21 level (Figure 8). These results indicate that p53 is required for vanadate-induced $\mathrm{p} 21$ activation. 


\section{II.5. DISCUSSION}

The present study investigated vanadate-induced cell growth arrest and the role of p53. The results obtained from this study demonstrate that: (a) vanadate induced S phase arrest in a dose- and time-dependent manner in p53 wild type C141 cells, while no significant change was observed in p53 -/- cells; (b) vanadate caused a dose- and timedependent increase in p53 activity in C141 cells; (c) PFT, a specific inhibitor of p53, blocked the p53 activity with a concomitant decrease in the percentage of $\mathrm{S}$ phase induced by vanadate; (d) vanadate activated p21 in a dose- and time-dependent manner in C141 cells while no change was observed in p53 -/- cells; (e) PFT inhibited p21 expression in vanadate stimulated C141 cells.

The ability of cells to maintain genomic integrity is vital for cell survival and proliferation. The important part in cell growth regulation is the ability of cells to pause transiently during the cell cycle in response to agents that cause damage, particularly to DNA. Surveillance controls the mechanisms that check and ensure proper completion of early events and cellular integrity before initiation of subsequent events in cell cycle progression. This process can cause a transient delay that has been suggested to allow the cells more time to repair damage before progressing to the next phase $(20,21)$. Alternatively, if the damage is too severe to be adequately repaired, the cells may undergo apoptosis or enter an irreversible senescence like state (20). In general, the toxic effects of vanadium are due to its inhibitory effects on certain enzymatic systems, mimicing and regulating growth factor activity and gene expression $(22,23)$. It has been reported that sodium vanadate causes $\mathrm{G}_{2} / \mathrm{M}$ arrest and $\mathrm{Rb}$ hypophosphorylation in $\mathrm{T} 98$ glioma cells (24), demonstrating that the $\mathrm{G}_{2} / \mathrm{M}$ arrest induced by a peroxovanadium

compound was related to the reduced activity of $\mathrm{p} 34^{\mathrm{cdc} 2}$ and inhibition of $\mathrm{Cdc} 25 \mathrm{C}(25)$. A $2 \mathrm{~h}$ exposure of the melanoma cells to sodium vanadate led to a decrease in the activity of cyclin D (26). Other studies have indicated that the mitogenesis induced by vanadate in CSV3-1 cells was associated with the induction of certain protooncogenes, $c$-jun and jun 
$B$, two major components of the AP-1 transcription factor (27). Our earlier study demonstrated that vanadate induced $\mathrm{G}_{2} / \mathrm{M}$ phase arrest in a dose- and time-dependent manner in human epithelial cell line, A549 (28). In the present study, the results showed that vanadate caused S phase arrest in mouse epidermal C141 cells. The difference in phase arrest induced by vanadate may be cell line specific.

The p53 tumor suppressor is a multifunctional protein that exerts a variety of different effects and plays a central role in the regulation of the normal cell cycle $(14,29)$. Overexpression of this protein was found to induce growth arrest associated with the $\mathrm{G}_{0} / \mathrm{G}_{1}$ checkpoint (8-10). At $\mathrm{G}_{0} / \mathrm{G}_{1}$ checkpoint, wild type $\mathrm{p} 53$ was associated with DNA repair activity, and this association prevented the entry into $S$ phase $(30,31)$. At $G_{2}$ checkpoint, p53 functions prior to mitosis and takes part in the spindle checkpoint associated with mitosis (32). p53 is important for securing the stability and integrity of the genome of normal cells and was suggested to be the 'guardian of the genome' (33). A variety of DNA insults were shown to stabilize the protein, which in turn can either cause growth arrest, permit the induction of the DNA repair process, or alternatively, direct cells to undergo apoptosis (34). p53 was suggested to be a sensor of damaged DNA, and may be involved in the repair process (35). It has been shown that cells containing wild type p53 alleles undergo $G_{1}$ arrest in response to $\gamma$-radiation, whereas cells lacking functional p53 alleles enter S phase regardless of dose of $\gamma$-radiation (36). It has been demonstrated that vanadate-mediated generation of reactive oxygen species (ROS) plays an important role in various adverse biological effects induced by this metal $(37,38)$. Moreover, ROS are believed to be capable of damaging DNA (39). Our earlier study showed that vanadate-induced apoptosis was p53 dependent which was mediated by $\mathrm{H}_{2} \mathrm{O}_{2}$ (40). Our previous study also suggested that ROS are mediators of vanadateinduced cell growth arrest (28). The results from the present study show that vanadate not only induces S phase arrest in C141 cells, but also causes an increase in p53 activity. Our study also showed that vanadate caused $\mathrm{S}$ phase arrest in p53 +/+ cells derived from mouse embryo fibroblasts similarly to that observed in C141 cells (unpublished 
observations). Due to lack of p53 in p53 -/- cells, vanadate failed to induce growth arrest at $\mathrm{S}$ phase. Although the mechanism involved in the vanadate-induced cell growth arrest remains to be investigated, it is known that ROS generated by vanadate-mediated reactions cause DNA damage. This DNA damage may activate signal transduction pathways, such as mitogen-activated protein kinase family, leading to an increase in p53 protein level and its phosphorylation. PFT, an inhibitor of p53, mainly inhibits p53 function (41). The results obtained from the present study show that addition of $10 \mu \mathrm{M}$ PFT decreased the p53 activity by $42 \%$ compared to the stimulated C141 cells (treated with $50 \mu \mathrm{M}$ vanadate for $24 \mathrm{~h}$ ). The inhibition was stronger when the concentration of PFT was increased to $20 \mu \mathrm{M}$, being about $60 \%$. More importantly, pretreatment with PFT significantly decreased the percentage of S phase induced by vanadate. The percentage of S phase in stimulated cells was $27 \%$. It was $8 \%$ or $5 \%$ after addition of PFT $10 \mu \mathrm{M}$ or 20 $\mu \mathrm{M}$, respectively. There was no significant difference in S phase between the PFT pretreated, vanadate-stimulated cells and the control cells (S phase, $8 \%$ ).

p21 (WAF-1/CIP1) is known to be a transactivation target of p53, and has been suggested to mediate p53-indcued growth arrest triggered by DNA damage (42). Induction of p21 expression could serve as an indicator for transactivation by p53, although p53-independent mechanisms were also observed $(14,29)$. Induction of p21 may inhibit cell progression in two ways: (a) by inhibiting a variety of cyclin/cdk complexes and (b) by inhibiting DNA synthesis through PCNA binding (43). It is known that cyclin A accumulates at the $G_{1} / S$ phase transition and persists through $S$ phase. Cyclin $A$ initially associates with cdk2 and then, in late S phase, associates with cdk1. Cyclin Aassociated kinase activity is required for entry into $\mathrm{S}$ phase, completion of S phase, and entry into M phase (44-46). The p21 protein inhibits the activity of cyclin $\mathrm{A} / \mathrm{cdk} 2$, which in turn phosphorylates the E2F heterodimerization DP1, resulting in an inhibition of E2F DNA-binding activity (43). The present study shows that vanadate indeed is able to cause a dose- and time-dependent increase in p21 protein level in C141 cells. In contrast, it was 
unable to activate p21 in p53 -/- cells regardless of dose or time of vanadate treatment. Furthermore, addition of PFT significantly decreased p21 protein level activated by vanadate, indicating that vanadate-induced activation of p21 is through p53-dependent pathway. Our preliminary data also showed that during p21 activation in p53 wild type cells vanadate reduced both cyclin A and cdk2 levels. This observation suggests that both activated p21 binding and inhibition of cdk2 are involved in vanadate-induced $\mathrm{S}$ phase arrest.

In conclusion, the results obtained from the present study demonstrate that vanadate is capable of inducing S phase arrest in C141 cells that contain wild type p53 alleles, and this interruption of cell cycle is p53-dependent. Activation of p53 leads to an increase in p21 expression, resulting in a pause in growth progression at $\mathrm{S}$ phase. Thus, vanadate-induced $\mathrm{S}$ phase arrest is mediated by p53 through activation of $\mathrm{p} 21$. 


\section{II.6. FIGURES}

A

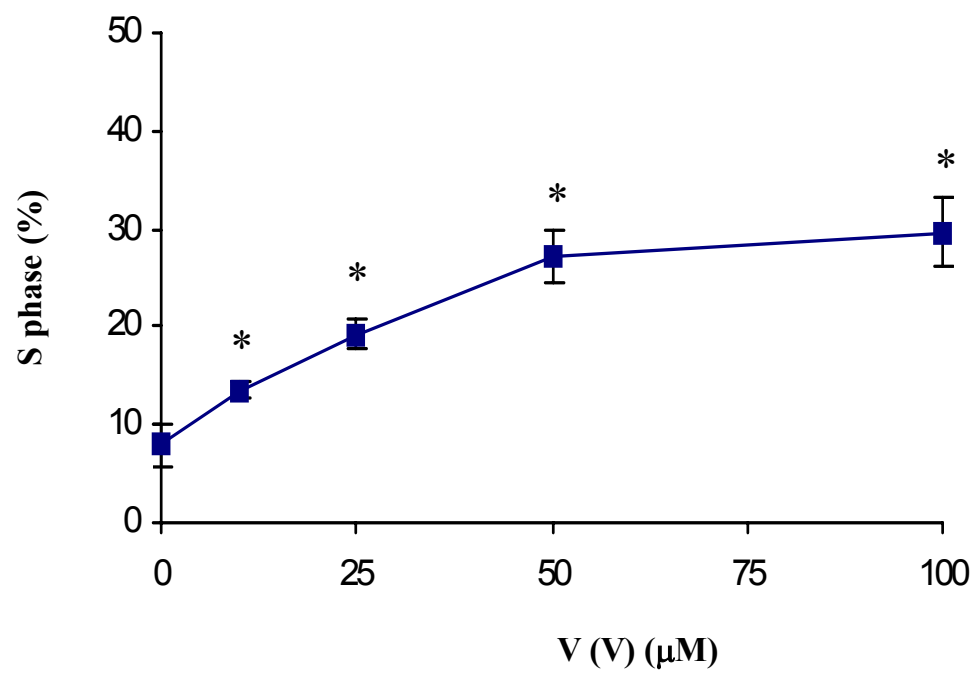

Figure 1 Vanadate-induced cell growth arrest in C141 cells. C141 cells were suspended in 5\% fetal bovine serum (FBS) MEM in a $100 \mathrm{~mm}$ dish. After $80-90 \%$ confluence, cells were washed with PBS three times, and treated with 10, 25, 50, $100 \mu \mathrm{M}$ vanadate for $24 \mathrm{~h}$ (Panel A). Cells were harvested and DNA content was measured by flow cytometry. Each point represents mean \pm SD of the percentage of $\mathrm{S}$ phase of three independent experiments. *, $\mathrm{p}<0.05$ compared to control (one-way ANOVA with Scheffe's test). 
B

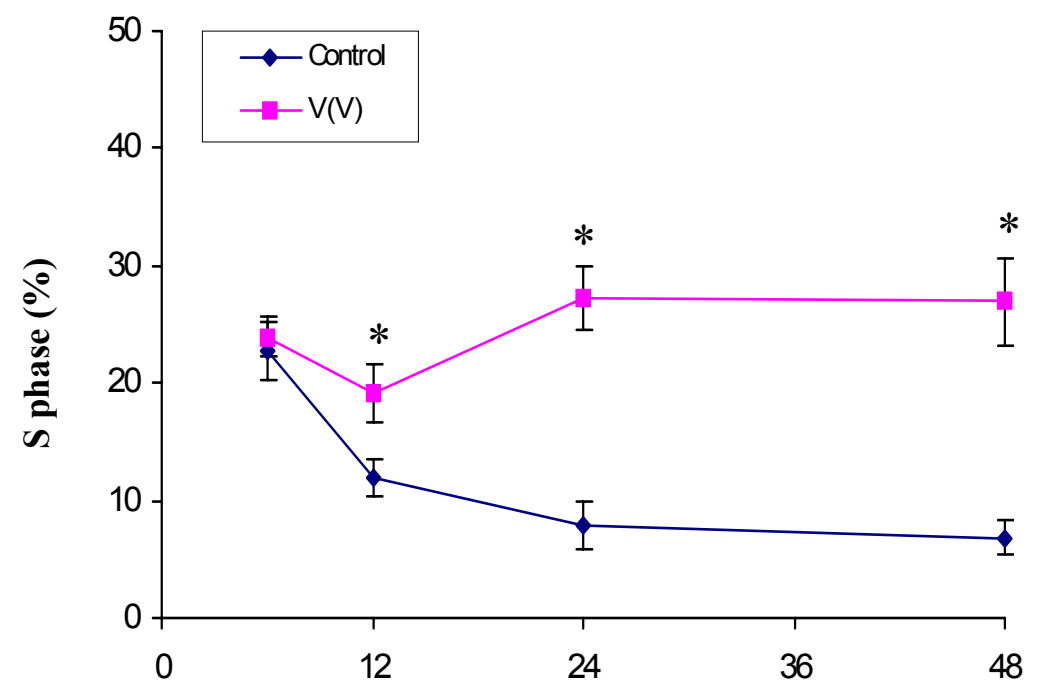

Time (h)

Figure 1 Vanadate-induced cell growth arrest in C141 cells. C141 cells were suspended in $5 \%$ fetal bovine serum (FBS) MEM in a $100 \mathrm{~mm}$ dish. After $80-90 \%$ confluence, cells were washed with PBS three times, and treated with $100 \mu \mathrm{M}$ vanadate for $6,12,24$ and $48 \mathrm{~h}$ (Panel B). Cells were harvested and DNA content was measured by flow cytometry. Each point represents mean \pm SD of the percentage of $\mathrm{S}$ phase of three independent experiments. *, $\mathrm{p}<0.05$ compared to control (one-way ANOVA with Scheffe's test). 
A

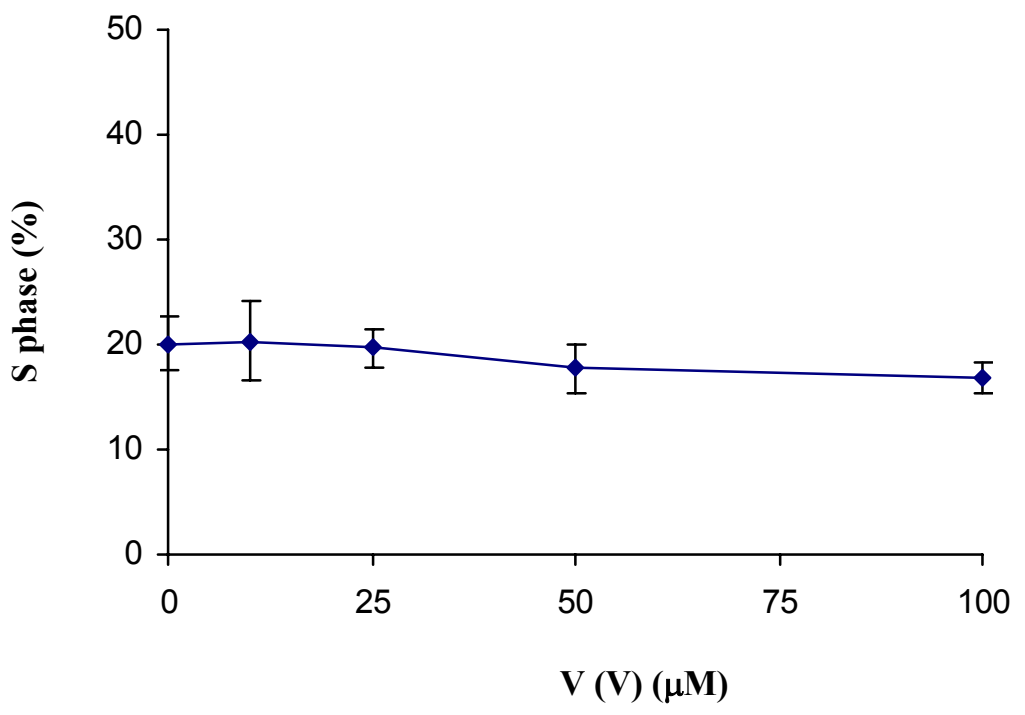

Figure 2 The effect of vanadate on cell growth in p53-deficient embryo fibroblasts (p53 -/-). p53 -/- cells were suspended in 10\% fetal bovine serum (FBS) DMEM in a $100 \mathrm{~mm}$ dish. After 80-90\% confluence, cells were washed with PBS three times, and treated with $10,25,50,100 \mu \mathrm{M}$ vanadate for $24 \mathrm{~h}$. Cells were harvested and DNA content was measured by flow cytometry. Each point represents mean $\pm \mathrm{SD}$ of the percentage of $\mathrm{S}$ phase of three independent experiments. * ${ }^{*}$ p $<0.05$ compared to control (one-way ANOVA with Scheffe's test). 
B

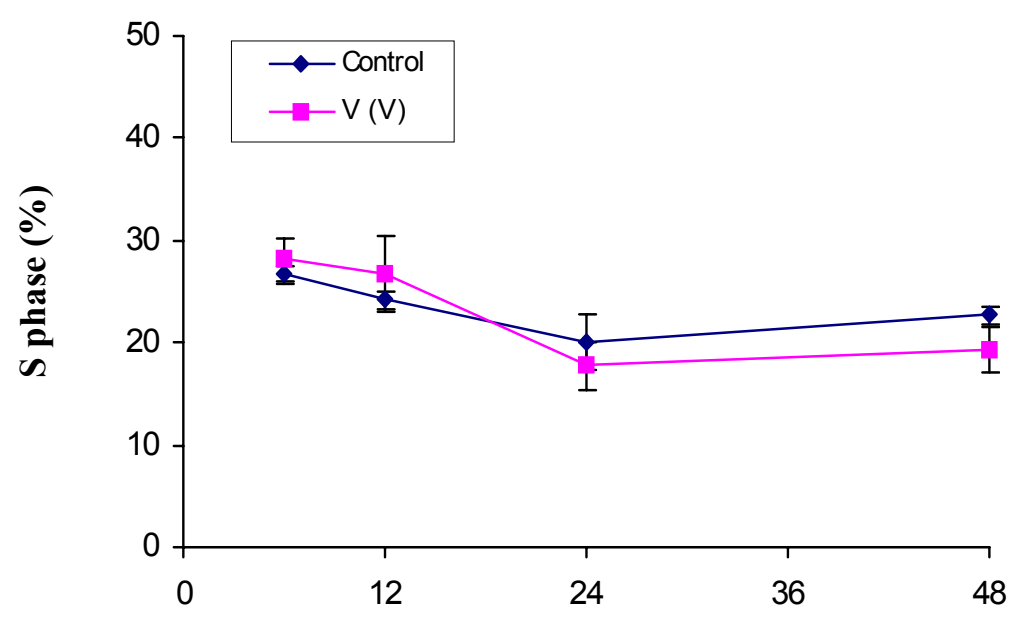

Time (h)

Figure 2 The effect of vanadate on cell growth in p53-deficient embryo fibroblasts (p53 -/-). p53 -/- cells were suspended in 10\% fetal bovine serum (FBS) DMEM in a $100 \mathrm{~mm}$ dish. After $80-90 \%$ confluence, cells were washed with PBS three times, and treated with $50 \mu \mathrm{M}$ vanadate for $6,12,24$ and $48 \mathrm{~h}$. Cells were harvested and DNA content was measured by flow cytometry. Each point represents mean $\pm \mathrm{SD}$ of the percentage of $\mathrm{S}$ phase of three independent experiments. *, $\mathrm{p}<0.05$ compared to control (one-way ANOVA with Scheffe's test). 
$\mathbf{A}$

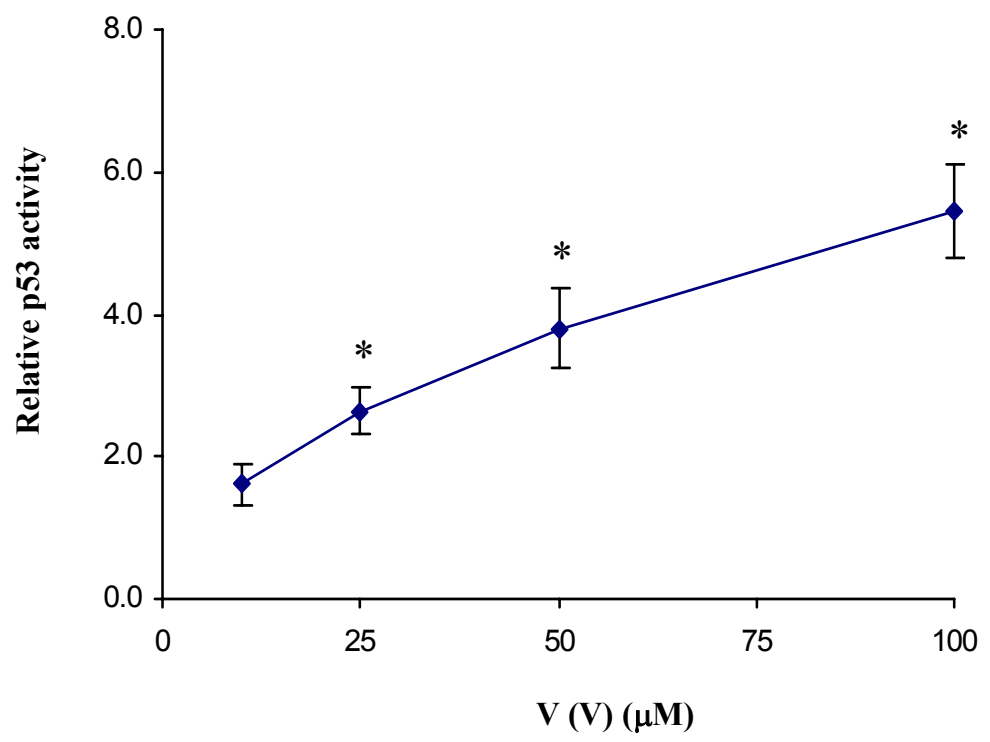

Figure 3 Vanadate-induced p53 activation in C141 cells. $1 \times 10^{4}$ cells were seeded into 96-well plate with $100 \mu$ medium each well. The cells were treated with 10 , $25,50,100 \mu \mathrm{M}$ vanadate for $24 \mathrm{~h}$. At time points, the cells were extracted with lysis buffer. The p53 luciferase activity was measured using a luminometer (moonlight 3010). The results were expressed as p53 activity relative to the control. Each point represents mean $\pm \mathrm{SD}$ of the percentage of $\mathrm{S}$ phase of three independent experiments. *, $\mathrm{p}<0.05$ compared to $10 \mu \mathrm{M}$ vanadate treatment (one-way ANOVA with Scheffe's test). 


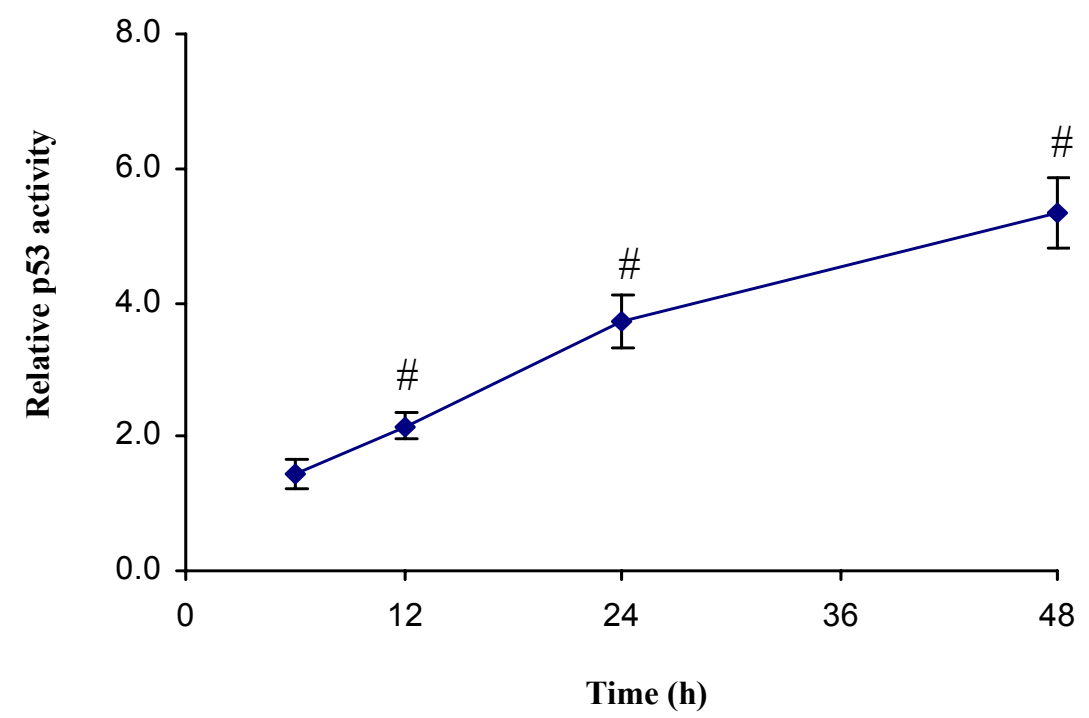

Figure 3 Vanadate-induced p53 activation in C141 cells. $1 \times 10^{4}$ cells were seeded into 96-well plate with $100 \mu 1$ medium each well. The cells were treated with 50 $\mu \mathrm{M}$ vanadate for $6,12,24$ and $48 \mathrm{~h}$. At time points, the cells were extracted with lysis buffer. The p53 luciferase activity was measured using a luminometer (moonlight 3010). The results were expressed as p53 activity relative to the control. Each point represents mean $\pm \mathrm{SD}$ of the percentage of $\mathrm{S}$ phase of three independent experiments. \#, $\mathrm{p}<0.05$ compared to $6 \mathrm{~h}$ vanadate treatment (one-way ANOVA with Scheffe's test). 


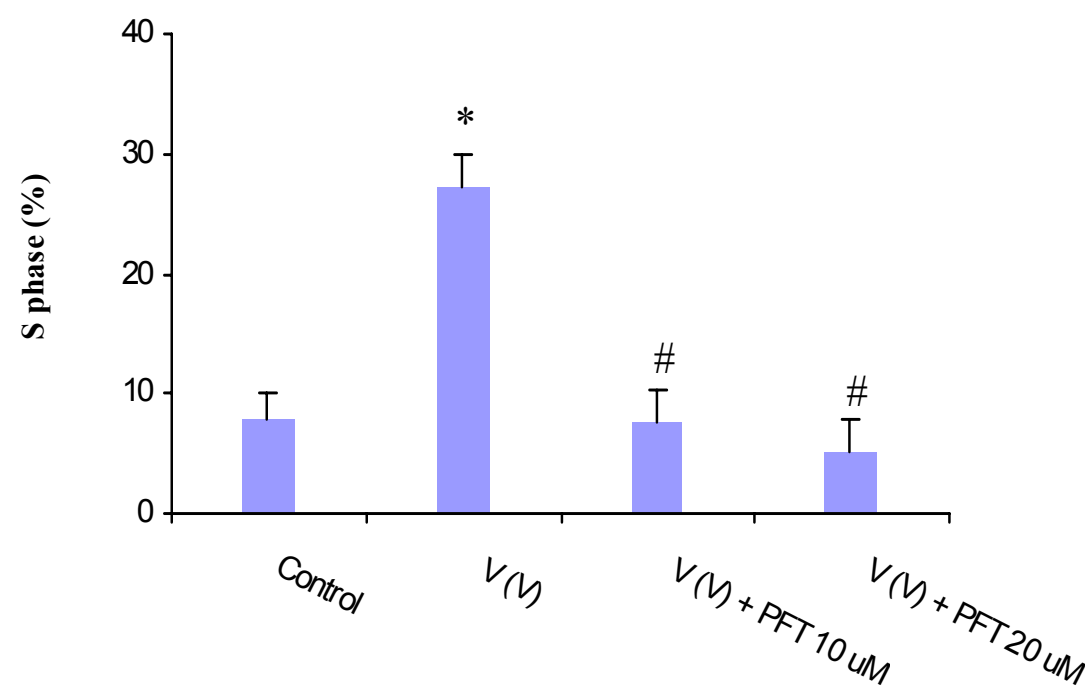

Figure 4 Inhibitory effects of PFT on vanadate-induced cell growth arrest in C141 cells. The cells were incubated in a $100 \mathrm{~mm}$ dish and pretreated with 10 and $20 \mu \mathrm{M}$ PFT for $0.5 \mathrm{~h}$ before vanadate treatment $(50 \mu \mathrm{M})$. After $24 \mathrm{~h}$, cells were harvested, and DNA content was measured by flow cytometry. Each point represents mean $\pm \mathrm{SD}$ of the percentage of $\mathrm{S}$ phase of three independent experiments. *, \#, $\mathrm{p}<0.05$ compared to control and vanadate treatment, respectively (one-way ANOVA with the Scheffe's test). 


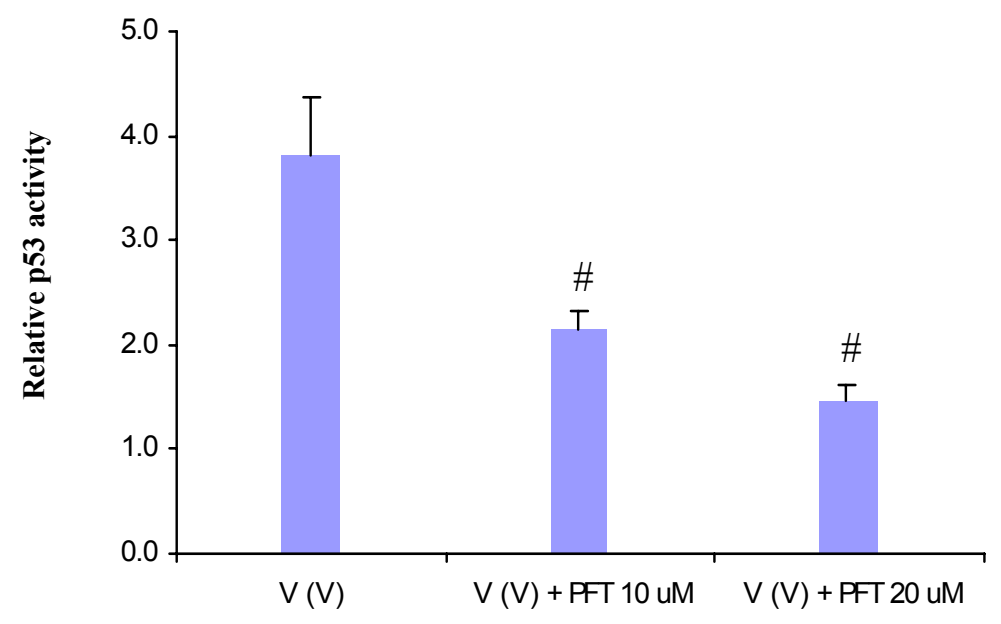

Figure 5 Inhibitory effects of PFT on vanadate-induced p53 activation in C141 cells. $1 \times 10^{4}$ cells were incubated in 96-well plate. The cells were pretreated with 10 and $20 \mu \mathrm{M}$ PFT for $0.5 \mathrm{~h}$ prior to vanadate stimulation $(50 \mu \mathrm{M})$. After $24 \mathrm{~h}$, the cells were extracted with lysis buffer. The p53 luciferase activity was measured using a luminometer (moonlight 3010). The results were expressed as p53 activity relative to the control. Each point represents mean $\pm \mathrm{SD}$ of the percentage of $S$ phase of three independent experiments. \#, $\mathrm{p}<0.05$ compared to vanadate treatment, respectively (one-way ANOVA with Scheffe's test). 


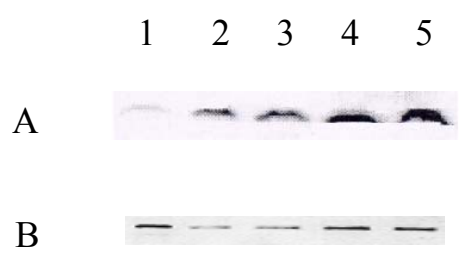

Figure 6 Time dependence of vanadate on p21 level in C141 cells and p53 -/- cells. Both types of cells were incubated in 6-well plate. The cells were treated with 50 $\mu \mathrm{M}$ vanadate for a different time. The whole cell lysates were collected for Western blotting using specific antibodies to p21. Panel A represented C141 cells and panel B represented p53 -/- cells. Lane 1, control; lane 2, 6 h; lane 3, $12 \mathrm{~h}$; lane 4, $24 \mathrm{~h}$; and lane 5, $48 \mathrm{~h}$. Data are from a single preparation representative of three indenpend experiments. 


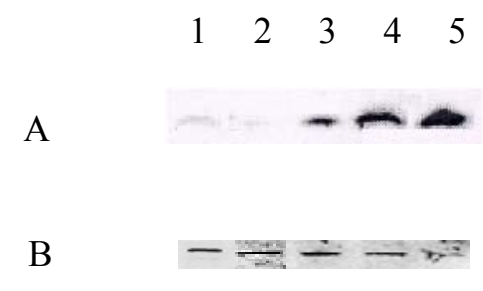

Figure 7 Dose-response study of vanadate on p21 level in C141 cells and p53 -/- cells. The method used is the same as Figure 6. The cells were treated with different concentrations of vanadate for $24 \mathrm{~h}$. Panel A represented C141 cells and panel B represented p53 -/- cells. Lane 1, control; lane 2, $10 \mu \mathrm{M}$ vanadate; lane 3, 25 $\mu \mathrm{M}$ vanadate; lane 4, $50 \mu \mathrm{M}$ vanadate; and lane 5, $100 \mu \mathrm{M}$ vanadate. Data are from a single preparation representative of three indenpend experiments. 


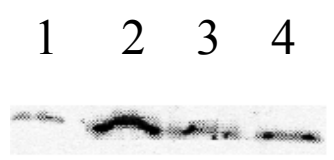

Figure 8 The inhibitory effects of PFT on p21 expression in C141 cells. The cells were pretreated with $10 \mu \mathrm{M}$ and $20 \mu \mathrm{M}$ PFT for $0.5 \mathrm{~h}$ prior to vanadate treatment (50 $\mu \mathrm{M}, 24 \mathrm{~h}$ ). Western blotting was used to examine the p21 level. Lane 1, control; lane 2, $50 \mu \mathrm{M}$ vanadate for $24 \mathrm{~h}$; lane 3, $50 \mu \mathrm{M}$ vanadate $+10 \mu \mathrm{M}$ PFT for $24 \mathrm{~h}$; and lane 4, $50 \mu \mathrm{M}$ vanadate $+20 \mu \mathrm{M}$ PFT for $24 \mathrm{~h}$. Data are from a single preparation representative of three indenpend experiments. 


\section{II.7. REFERENCES}

1. Hickey, R.J., Schoff E.P. and Clelland R.C. (1967) Relationship between air pollution and certain chronic disease death rates. Multivariate statistical studies. Arch Environ Health, 15, 728-38.

2. Stock, P. (1965) On the relations between atmospheric pollution in urban and rural location and mortality from cancer, bronchitis, pneumonia, with particular reference to 3,4-benzopyrene, beryllium, molybdenum, vanadium and arsenic. $\mathrm{Br}$ J Cancer, 14, 397-418.

3. Yin, X., Davison A.J. and Tsang S.S. (1992) Vanadate-induced gene expression in mouse C127 cells: roles of oxygen derived active species. Mol Cell Biochem, 115, 85-96.

4. Stern, A., Yin X., Tsang S.S., Davison A. and Moon J. (1993) Vanadium as a modulator of cellular regulatory cascades and oncogene expression. Biochem Cell Biol, 71, 103-12.

5. Shi, X., Jiang H., Mao Y., Ye J. and Saffiotti U. (1996) Vanadium(IV)-mediated free radical generation and related 2'- deoxyguanosine hydroxylation and DNA damage. Toxicology, 106, 27-38.

6. Shackelford, R.E., Kaufmann W.K. and Paules R.S. (1999) Cell cycle control, checkpoint mechanisms, and genotoxic stress. Environ Health Perspect, 107 Suppl 1, 5-24.

7. Ko, J.L., Cheng Y.W., Chang S.L., Su J.M., Chen C.Y. and Lee H. (2000) MDM2 mRNA expression is a favorable prognostic factor in non-small-cell lung cancer. Int $J$ Cancer, 89, 265-70.

8. Shaulsky, G., Goldfinger N., Peled A. and Rotter V. (1991) Involvement of wildtype p53 in pre-B-cell differentiation in vitro. Proc Natl Acad Sci US A, 88, 8982-6. 
9. Michalovitz, D., Halevy O. and Oren M. (1990) Conditional inhibition of transformation and of cell proliferation by a temperature-sensitive mutant of p53. Cell, 62, 671-80.

10. Diller, L., Kassel J., Nelson C.E., Gryka M.A., Litwak G., Gebhardt M., Bressac B., Ozturk M., Baker S.J., Vogelstein B. and et al. (1990) p53 functions as a cell cycle control protein in osteosarcomas. Mol Cell Biol, 10, 5772-81.

11. Yonish-Rouach, E., Grunwald D., Wilder S., Kimchi A., May E., Lawrence J.J., May P. and Oren M. (1993) p53-mediated cell death: relationship to cell cycle control. Mol Cell Biol, 13, 1415-23.

12. Oren, M. (1994) Relationship of p53 to the control of apoptotic cell death. Semin Cancer Biol, 5, 221-7.

13. Aloni-Grinstein, R., Schwartz D. and Rotter V. (1995) Accumulation of wild-type p53 protein upon gamma-irradiation induces a G2 arrest-dependent immunoglobulin kappa light chain gene expression. EMBO J, 14, 1392-401.

14. Rotter, V., Aloni-Grinstein R., Schwartz D., Elkind N.B., Simons A., Wolkowicz R., Lavigne M., Beserman P., Kapon A. and Goldfinger N. (1994) Does wild-type p53 play a role in normal cell differentiation? Semin Cancer Biol, 5, 229-36.

15. Harper, J.W., Adami G.R., Wei N., Keyomarsi K. and Elledge S.J. (1993) The p21 Cdk-interacting protein Cip1 is a potent inhibitor of G1 cyclin-dependent kinases. Cell, 75, 805-16.

16. el-Deiry, W.S., Tokino T., Velculescu V.E., Levy D.B., Parsons R., Trent J.M., Lin D., Mercer W.E., Kinzler K.W. and Vogelstein B. (1993) WAF1, a potential mediator of p53 tumor suppression. Cell, 75, 817-25.

17. Michieli, P., Chedid M., Lin D., Pierce J.H., Mercer W.E. and Givol D. (1994) Induction of WAF1/CIP1 by a p53-independent pathway. Cancer Res, 54, 3391-5.

18. Sgonic, R.a.W., G (1994.) Methods for the detection of apoptosis. Int Arch Allergy Immunol, 105, 327-332. 
19. Nicoletti, I., Migliorati, G., Pagliacci, M.C., Grignani, F. and Riccardi, C. (1991) A rapid and simple method for measuring thymocyte apoptosis by propidium iodide staining and flow cytometry. J Immunol Methods, 139, 271-279.

20. Kastan, M.B. (1997) Checkpoint controls and cancer. Cold spring harbor laboratory press, Plainview, NY.

21. Hartwell, L.H. and Weinert T.A. (1989) Checkpoints: controls that ensure the order of cell cycle events. Science, 246, 629-34.

22. Cruz, T.F., Morgan A. and Min W. (1995) In vitro and in vivo antineoplastic effects of orthovanadate. Mol Cell Biochem, 153, 161-6.

23. Swarup, G., Cohen S. and Garbers D.L. (1982) Inhibition of membrane phosphotyrosyl-protein phosphatase activity by vanadate. Biochem Biophys Res Commun, 107, 1104-9.

24. Chin, L.S., Murray S.F., Harter D.H., Doherty P.F. and Singh S.K. (1999) Sodium vanadate inhibits apoptosis in malignant glioma cells: a role for Akt/PKB. $J$ Biomed Sci, 6, 213-8.

25. Faure, R., Vincent M., Dufour M., Shaver A. and Posner B.I. (1995) Arrest at the $\mathrm{G} 2 / \mathrm{M}$ transition of the cell cycle by protein-tyrosine phosphatase inhibition: studies on a neuronal and a glial cell line. $J$ Cell Biochem, 59, 389-401.

26. Strasberg Rieber, M. and Rieber M. (1995) Suppression of cyclin D1 but not cdk4 or cyclin A with induction of melanoma terminal differentiation. Biochem Biophys Res Commun, 216, 422-7.

27. Wang, H., Xie Z. and Scott R.E. (1997) Induction of AP-1 activity associated with c-Jun and JunB is required for mitogenesis induced by insulin and vanadate in SV40-transformed 3T3T cells. Mol Cell Biochem, 168, 21-30.

28. Zhang, Z., Huang C., Li J., Leonard S.S., Lanciotti R., Butterworth L. and Shi X. (2001) Vanadate-induced cell growth regulation and the role of reactive oxygen species. Arch Biochem Biophys, 392, 311-20.

29. Almog, N. and Rotter V. (1997) Involvement of p53 in cell differentiation and development. Biochim Biophys Acta, 1333, F1-27. 
30. Nelson, W.G. and Kastan M.B. (1994) DNA strand breaks: the DNA template alterations that trigger p53- dependent DNA damage response pathways. Mol Cell Biol, 14, 1815-23.

31. Lu, X. and Lane D.P. (1993) Differential induction of transcriptionally active p53 following UV or ionizing radiation: defects in chromosome instability syndromes? Cell, 75, 765-78.

32. Cross, S.M., Sanchez C.A., Morgan C.A., Schimke M.K., Ramel S., Idzerda R.L., Raskind W.H. and Reid B.J. (1995) A p53-dependent mouse spindle checkpoint. Science, 267, 1353-6.

33. Lane, D.P. (1992) Cancer. p53, guardian of the genome. Nature, 358, 15-6.

34. Livingstone, L.R., White A., Sprouse J., Livanos E., Jacks T. and Tlsty T.D. (1992) Altered cell cycle arrest and gene amplification potential accompany loss of wild-type p53. Cell, 70, 923-35.

35. Sanchez, Y. and Elledge S.J. (1995) Stopped for repairs. Bioessays, 17, 545-8.

36. Di Leonardo, A., Linke S.P., Clarkin K. and Wahl G.M. (1994) DNA damage triggers a prolonged p53-dependent G1 arrest and long-term induction of Cip1 in normal human fibroblasts. Genes Dev, 8, 2540-51.

37. Shi, X. and Dalal N.S. (1992) Hydroxyl radical generation in the NADH/microsomal reduction of vanadate. Free Radic Res Commun, 17, 369-76.

38. Ye, J., Ding M., Leonard S.S., Robinson V.A., Millecchia L., Zhang X., Castranova V., Vallyathan V. and Shi X. (1999) Vanadate induces apoptosis in epidermal JB6 P+ cells via hydrogen peroxide-mediated reactions. Mol Cell Biochem, 202, 9-17.

39. Payne, C.M., Bernstein C. and Bernstein H. (1995) Apoptosis overview emphasizing the role of oxidative stress, DNA damage and signal-transduction pathways. Leuk Lymphoma, 19, 43-93.

40. Huang, C., Zhang Z., Ding M., Li J., Ye J., Leonard S.S., Shen H.M., Butterworth L., Lu Y., Costa M., Rojanasakul Y., Castranova V., Vallyathan V. and Shi X. 
(2000) Vanadate induces p53 transactivation through hydrogen peroxide and causes apoptosis. J Biol Chem, 275, 32516-22.

41. Komarova, E.A. and Gudkov A.V. (2000) Suppression of p53: a new approach to overcome side effects of antitumor therapy. Biochemistry (Mosc), 65, 41-8.

42. Hunter, T. (1993) Braking the cycle. Cell, 75, 839-41.

43. Johnson, D.G. and Walker C.L. (1999) Cyclins and cell cycle checkpoints. Annu Rev Pharmacol Toxicol, 39, 295-312.

44. Walker, D.H. and Maller J.L. (1991) Role for cyclin A in the dependence of mitosis on completion of DNA replication. Nature, 354, 314-7.

45. Lehner, C.F. and O'Farrell P.H. (1989) Expression and function of Drosophila cyclin A during embryonic cell cycle progression. Cell, 56, 957-68.

46. Girard, F., Strausfeld U., Fernandez A. and Lamb N.J. (1991) Cyclin A is required for the onset of DNA replication in mammalian fibroblasts. Cell, 67, 1169-79. 


\section{SECTION III}

Vanadate Induces $\mathrm{G}_{2} / \mathbf{M}$ Phase Arrest in p53 Deficient Mouse

Embryo Fibroblasts 


\section{III.1. ABSTRACT}

Vanadium compounds exert potent toxic and carcinogenic effects on a wide variety of biological systems. The mechanisms involved in their toxicity and carcinogenesis remain to be investigated. Cell growth arrest and its regulation are important mechanisms in maintaining genomic stability and integrity in response to environmental stress. The p53 tumor suppressor plays a central role in the regulation of the normal cell cycle. In order to investigate the role of p53 in vanadate-induced cell growth arrest and its regulation, two cell lines, normal mouse embryo fibroblasts (p53 $+/+$ ) and p53 deficient mouse embryo fibroblasts (p53 -/-), were used in the present study. Flow cytometry was used to analyze cell growth arrest at $G_{0} / G_{1}, S$ or $G_{2} / M$ phase. Western blotting analysis was performed to determine several cell growth regulatory proteins. The results show that in p53 -/- cells vanadate induced $\mathrm{G}_{2} / \mathrm{M}$ phase arrest in a dose- and time-dependent manner without alteration of $\mathrm{S}$ phase. In p53 +/+ cells, vanadate treatment increased $S$ phase with no significant change at $G_{2} / M$ phase. Furthermore, Western blotting results show that in p53 -/- cells vanadate caused cdc25C degradation and activation of phospho-cdc2 without alteration of p21 level. In p53 +/+ cells, vanadate increased expression of p21 and degraded cdc25A instead of cdc25C without any effect on cdc2. These results demonstrate that vanadate induced $G_{2} / M$ phase arrest in p53 deficient mouse embryo fibroblasts, and caused S phase arrest in p53 wild type mouse embryo fibroblasts. 


\section{III.2. INTRODUCTION}

The ability of cells to maintain genomic integrity is vital for cell survival and proliferation. Lack of fidelity in DNA replication and maintenance results in deleterious mutations leading to cell death or cancer (1). Surveillance systems exist to ensure proper completion of cell cycle progression. The transition stages of cell cycle are regulated by various protein kinases or their complexes composed of cyclin and cyclin-dependent kinases (2). Checkpoints can induce a transient delay to provide the cells more time to repair the damage before progression to the next phase of cell cycle (1).

The p53 tumor suppressor gene is a transcription factor that plays an important role in signal transduction in response to DNA damage (3). p53 mediates various cellular functions such as DNA repair, maintenance of genetic stability, and induction of cell cycle arrest or apoptosis. It has been reported that both p53-dependent and p53independent pathways are involved in the cell cycle regulation (4). Generally, p53 is considered an important factor in the regulation of cell cycle. p53-dependent cell growth arrest in $\mathrm{G}_{1}$ phase is an important component of the cellular response to stress. Recent study indicates that p53 controls the entry into mitosis when cells enter $G_{2}$ phase with damaged DNA or when they are arrested in S phase due to depletion of the substrates required for DNA synthesis (5).

Vanadium is widely distributed in the environment and is a trace metal in biological systems (6-8). Vanadate compounds are potent toxins and carcinogens (9-12). Epidemiological studies have shown a correlation between vanadium exposure and the incidence of lung cancer in humans $(13,14)$. Vanadate compounds were reported to modify DNA synthesis and repair (15-18). Vanadate was also shown to induce forward mutation and DNA-protein crosslinks in cultured mammalian cells (19). It also has been reported that vanadate exhibits mitogenic effects by inhibiting the activity of tyrosine phosphatase and triggering the autophosphorylation of tyrosine kinase on cell membrane 
receptors (20). Vanadate regulates growth-factor-mediated signal transduction pathways, promotes cell transformation, exerts inhibitory effects on certain enzymatic systems, and decreases cell adhesion (21-23). While the mechanisms of vanadate-induced toxicity and carcinogenicity remain to be investigated, reactive oxygen species (ROS) are considered to play an important role. Through ROS, vanadate compounds cause direct DNA damage, such as strand breaks and hydroxylation of $\mathrm{dG}$ residues, activate certain nuclear transcription factors, such as AP-1 (24), NF- $\mathrm{kB}$ (25), p53 (26) and nuclear factor of activated T cells (NFAT) (27), and induce apoptosis $(26,28)$. Our previous studies have found that vanadate-induced cell growth arrest is cell type specific. Vanadate caused $\mathrm{G}_{2} / \mathrm{M}$ phase arrest in human epithelial A549 cell line, and this arrest is mediated by ROS (29).

The purpose of present study was to investigate the role of p53 in vanadateinduced cell growth arrest and to attempt to answer the following questions: 1), Does vanadate induce cell growth arrest in mouse embryo fibroblasts? 2), Does p53 mediate the vanadate-induced cell growth arrest? 3), What checkpoints are involved in the cell cycle regulation? 


\section{III.3. MATERIALS AND METHODS}

Reagents Sodium metavanadate was from Aldrich (Milwaukee, WI). RNase A and DMEM medium were purchased from Sigma (St. Louis, MO). Propidium iodide (PI) was from Molecular Probes (Eugene, OR). Fetal bovine serum (FBS) was from Gibco BRL (Life Technologies, Gaithersburg, MD). Antibodies against p21, cdc25A, cdc25C were from Santa Cruz Biotechnology (Santa Cruz, CA). Phospho-cdc2 $2^{\text {tyr15 }}$ and secondary AP linked anti-rabbit IgG were from Cell Signaling (Beverly, MA).

Cell culture Normal mouse embryo fibroblasts (p53 +/+) and p53-deficient mouse embryo fibroblasts (p53 -/-) were incubated in DMEM medium with 10\% FBS, 2 $\mathrm{mM} \mathrm{L}$-glutamine, and $1000 \mathrm{U} / \mathrm{ml}$ penicillin-streptomycin in an incubator at $5 \% \mathrm{CO}_{2}$ and $37^{\circ} \mathrm{C}$.

Treatments For the time-course study, cells were treated with $50 \mu \mathrm{M}$ vanadate for $6,12,24$, and $48 \mathrm{~h}$. For the dose-response study, cells were treated with 10, 25, 50, and $100 \mu \mathrm{M}$ vanadate for $24 \mathrm{~h}$.

Measurement of cell cycle/DNA content DNA content in $\mathrm{G}_{2} / \mathrm{M}$ phase was analyzed using flow cytometry according to the methods described previously $(30,31)$. Cells were fixed and permeabilized with $70 \%$ ethanol for more than $2 \mathrm{~h}$, and then incubated with the freshly prepared staining buffer $(0.1 \%$ Triton X-100, $200 \mu \mathrm{g} / \mathrm{ml}$ RNase A, and $20 \mu \mathrm{g} / \mathrm{ml} \mathrm{PI)} \mathrm{for} 30 \mathrm{~min}$ at room temperature. Cell cycle analysis was performed by flow cytometry with at least 10,000 cells for each sample. The DNA content histogram was abstracted and the percentage of cells in $\mathrm{G}_{2} / \mathrm{M}$ phase was calculated using ModFit LT software. 
Western blotting analysis Whole cell extracts were mixed with Tris-Glycine SDS sample buffer and the proteins were separated by Tris-Glycine gel electrophoresis. The resolved proteins were transferred to a PVDF membrane. Western blotting was performed using antibodies to $\mathrm{p} 21, \operatorname{cdc} 25 \mathrm{~A}, \operatorname{cdc} 25 \mathrm{C}$, phospho-cdc $2^{\mathrm{tyr} 15}$ and secondary anti-rabbit IgG. After reaction with ECF substrate, the signal was detected using a Storm Scanner (Molecular Dynamics, Sunnyvale, CA).

Statistical analysis All data were based on at least three independent experiments. Cell growth arrest data were presented as means $\pm \mathrm{SD}$ and analyzed using one-way ANOVA with the Scheffe's test. A $p$ value less than 0.05 was considered statistically significant. 


\section{III.4. RESULTS}

Effects of vanadate in celll cycle To study vanadate-induced cell growth arrest, flow cytometry was used to measure the percentage of cells in each phase. Figure 1a shows a typical histogram of cell cycle. The first peak represents the $G_{0} / G_{1}$, the second one $\mathrm{G}_{2} / \mathrm{M}$, and that between these two peaks is $\mathrm{S}$ phase. As shown in Figure $1 \mathrm{~A}$, treatment of p53 -/- cells with $50 \mu \mathrm{M}$ vanadate for $24 \mathrm{~h}$ increased the percentage of the cells at $\mathrm{G}_{2} / \mathrm{M}$ phase, being $42 \%$ vs $18 \%$ in control. Interestingly, treatment of p53 +/+ cells with vanadate did not change the percentage of cells at $\mathrm{G}_{2} / \mathrm{M}$ phase. However, vanadate stimulation caused an increase in $\mathrm{S}$ phase.

Figure 1B shows the time dependence of vanadate-induced cell growth arrest at $\mathrm{G}_{2} / \mathrm{M}$ phase. As shown in this figure, in p53 -/- cells, the percentage of cells at $\mathrm{G}_{2} / \mathrm{M}$ phase increased from $18 \%$ at beginning of treatment to $42 \%$ when the cells were treated with vanadate for $24 \mathrm{~h}$. In contrast, in p $53+/+$ cells the percentage of cells at $\mathrm{G}_{2} / \mathrm{M}$ phase did not change with vanadate exposure.

Figure 1C shows the dose-dependence of vanadate-induced cell growth arrest at $\mathrm{G}_{2} / \mathrm{M}$ phase. As shown in this figure, in p53 -/- cells there was a dose-dependent increase at $\mathrm{G}_{2} / \mathrm{M}$ phase. The highest percentage of cells at $\mathrm{G}_{2} / \mathrm{M}$ phase was $42 \%$ when the cells were treated with $50 \mu \mathrm{M}$ vanadate for $24 \mathrm{~h}$. In p53 +/+ cells, the percentage of cells at $\mathrm{G}_{2} / \mathrm{M}$ phase was essentially unchanged regardless of the concentrations of vanadate.

Effects of vanadate on p21 One of the important cell growth regulatory proteins is $\mathrm{p} 21$. The protein level of this enzyme was measured by Western blotting. Figure 2, panel A shows that treatment of p53 -/- cells with $50 \mu \mathrm{M}$ vanadate for $6 \mathrm{~h}$ and $12 \mathrm{~h}$ decreased p21 level. No significant change was observed at $24 \mathrm{~h}$ or $48 \mathrm{~h}$ of vanadate treatment. The treatment of p $53+/+$ cells with $50 \mu \mathrm{M}$ vanadate for $6 \mathrm{~h}$ and $12 \mathrm{~h}$ caused a 
weak induction of p21. A marginal increase of p21 was observed at $24 \mathrm{~h}$ and $48 \mathrm{~h}$ of 50 $\mu \mathrm{M}$ vanadate treatment. Panel B shows dose-dependence of vanadate treatment. In p53 /- cells, at $24 \mathrm{~h}$ incubation, vanadate did not cause p21 induction regardless vanadate concentrations. In p $53+/+$ cells, $10 \mu \mathrm{M}$ vanadate caused an observable p21 induction. An increase in vanadate concentrations did not enhance the p21 induction.

Effects of vanadate on cdc25C To investigate involvement of cell cycle regulatory protein, expression of cdc $25 \mathrm{C}$ was examined in both p53 -/- cells and p53 +/+ cells. Figure 3 shows that in p53 -/- cells vanadate caused a time- and dose-dependent degradation of cdc25C (panels A and B). The cdc25C signal almost disappeared in cells treated with $50 \mu \mathrm{M}$ vanadate for $24 \mathrm{~h}$ and $48 \mathrm{~h}$ (panel A, lanes 4 and 5), and $100 \mu \mathrm{M}$ vanadate for $24 \mathrm{~h}$ (panel B, lanes 4 and 5). However, in p53 +/+ cells the cdc25C did not exhibit any significant change regardless of incubation times (panel A) or treatment concentrations (panel B).

Effects of vanadate on cdc25A Tyrosine phosphotase cdc25A was detected using Western blotting (Figure 4). In p53 -/- cells the expression of cdc25A did not change regardless of vanadate stimulation times (panel A) or doses (panel B). In p53 +/+ cells, $50 \mu \mathrm{M}$ vanadate treatment caused maximal degradation of cdc25A at $48 \mathrm{~h}$ (panel A, lane 5). The degradation of this protein was also observed when the cells were treated with 50 $\mu \mathrm{M}$ vanadate for $24 \mathrm{~h}$ (panel B, lane 4 ).

Effects of vanadate on cdc2 Another important kinase in the control of cell cycle progression from $G_{2}$ to $M$ phase is cdc2. Western blotting was also used to study the effects of vanadate on this protein. Figure 5, panel A shows that in p53 -/- cells treatment with $50 \mu \mathrm{M}$ vanadate activated phospho-cdc 2 at $6 \mathrm{~h}$ to $24 \mathrm{~h}$. In contrast, in p53 +/+ cells, vanadate caused a decrease in cdc2 at $12 \mathrm{~h}$ (panel A, lane 3) and a complete inhibition at $24 \mathrm{~h}$ (panel A, lane 4) when the cells were treated with $50 \mu \mathrm{M}$ vanadate. In p53 -/- cells, a 
dose-independent increase in cdc2 was observed after $10 \mu \mathrm{M}$ to $50 \mu \mathrm{M}$ vanadate treatment. Treatment of $\mathrm{p} 53+/+$ cells with vanadate at $25 \mu \mathrm{M}$ and $50 \mu \mathrm{M}$ decreased cdc 2 (panel B, lanes 3 and 4). 


\section{III.5. DISCUSSION}

Damage to growing cells causes a temporary pause in $\mathrm{G}_{1} / \mathrm{S}$, or $\mathrm{G}_{2} / \mathrm{M}$ phase until the damage is repaired. When damage is severe, cells may either undergo apoptosis or enter a dormant $\mathrm{G}_{0}$ state (32-34).

Similar to apoptosis or programmed cell death, cell growth arrest is a cell self defense system to prevent genetically damaged cells from passing to the next generation. Investigation on the cell growth arrest upon exposure of the cells to a carcinogen is an important part for the overall understanding of the mechanism of chemical-induced carcinogenesis. Vanadate-containing compounds exert potent toxic and carcinogenic effects on a wide variety of biological systems, although the mechanisms involved are still unclear. Using human epithelial cell line, A549 cells, our previous study has shown that vanadate is able to induce cell growth arrest at $\mathrm{G}_{2} / \mathrm{M}$ phase. This arrest is mediated by vanadate-induced ROS reactions. Mitogen-activated protein kinases (MAPKs) also play a critical role in the regulation of vanadate-induced cell growth arrest at $\mathrm{G}_{2} / \mathrm{M}$ phase (29). The results from our laboratory demonstrated that vanadate caused S phase arrest in C141 cells. The regulation of the $\mathrm{S}$ phase arrest is both $\mathrm{p} 53$ and $\mathrm{p} 21$-dependent (unpublished observations). The present study shows that vanadate induces $G_{2} / M$ phase arrest in a dose- and time-dependent manner in p53 -/- mouse embryo fibroblasts. In contrast, vanadate had no effect on $\mathrm{G}_{2} / \mathrm{M}$ phase but caused $\mathrm{S}$ phase arrest in p53 +/+ cells. It may be noted that hematopoietic cells that either lack p53 gene expression or overexpress a mutant form of the p53 gene exhibited $\mathrm{G}_{2}$ arrest after gamma-irradiation, confirming that the $\mathrm{G}_{2}$ arrest can be $\mathrm{p} 53$ independent (35). A recent study from our group demonstrated that induction of GADD $45 \alpha$ in arsenite-induced $\mathrm{G}_{2} / \mathrm{M}$ phase arrest was p53-independent. Moreover, the activation of GADD45 $\alpha$ by arsenite was higher in p53 /- cells than in p53 +/+ cells. All these data indicate that the $\mathrm{G}_{2} / \mathrm{M}$ phase arrest can be p53 independent (36). However, some studies have shown the importance of p53 in $\mathrm{G}_{2} / \mathrm{M}$ 
arrest. For example, p53 is required for the $\mathrm{G}_{2}$ arrest in response to ionizing radiation in IMR-90 normal lung fibroblasts (37). Other studies have indicated that inactivation of p53 by large $T$ antigen is responsible for abrogating the $\mathrm{G}_{2}$ checkpoint (38-40). Caffeine abrogated $\mathrm{G}_{2}$ arrest in response to ionizing radiation in mouse embryo fibroblasts derived from p53-knockout mice and in rat embryo fibroblasts expressing the dominant negative V143A mutant of human p53 (41).

Checkpoints are control mechanisms that ensure the proper timing of cell cycle events by enforcing the dependency of later events on the completion of early events. Movement of cells from $\mathrm{G}_{2} / \mathrm{M}$ is regulated by both cyclin $\mathrm{A}$ and cdc2/cyclin $\mathrm{B}$. The activity of cdc2/cyclin B kinases peaks in late $\mathrm{G}_{2}$ and remains high until their degradation (42). Earlier studies have shown that $\mathrm{G}_{2} / \mathrm{M}$ arrest induced by a peroxovanadium compound was related to the reduced activity of $\mathrm{p} 34^{\mathrm{cdc} 2}$ and inhibition of cdc25C (43). Our previous study also showed that sodium vanadate-induced $\mathrm{G}_{2} / \mathrm{M}$ phase arrest was regulated by both phospho-cdc $2^{\text {tyr15 }}$ and $\operatorname{cdc} 25 \mathrm{C}$ (29). $\gamma$-irradiation resulted in an accumulation of Thr14/Tyr15 phosphorylated cdc2, leading to inhibition of cdc2/cyclin B activity $(2,44)$. It has been reported that sodium vanadate caused $G_{2} / M$ arrest and $R b$ hypophosphorylation in T98 glioma cells (45). The present study shows that vanadate activated phospho-cdc2 in p53 -/- cells. But it decreased phospho-cdc2 in p53 +/+ cells.

There are two pathways associated with activation of cdc2/cyclin B complex: (a) cdc25C phosphatase associates with cdc2/cyclin B complex and activates it by dephosphorylated Thr14/Tyr15 (46), and this association between cde25C and cdc2/cyclin B complex may be blocked through the actions of the Chk1 and Chk2 kinases which phosphorylate cdc25C on serine 216 (1). This phosphorylation is necessary for cdc25C to bind to $14-3-3$ proteins and its apparent sequestration from the cdc $2 /$ cyclin B complex (47-49). (b) Transcriptional activation of $\mathrm{p} 21^{\mathrm{WAF} 1 / \mathrm{CIP} 1}$ makes this protein bind to and inactivates cdc2/cyclin B complex that is required for the cell cycle progression (5052). Our results show: (a) Vanadate was able to cause degradation of cdc $25 \mathrm{C}$ in p53 -/- 
cells. The degradation of this protein leads to failure in dephosphorylation of cdc2 at Tyr15, resulting in inactivation of the cdc2/cyclin B complex. Instead of $\operatorname{cdc} 25 \mathrm{C}$, cdc25A, a checkpoint phosphotase for S phase, was degraded in vanadate-stimulated p53 +/+ cells. (b) Vanadate had no effect on p21 level in p53 -/- cells regardless of treatment time and dose due to the deficiency of p53, although the activation of p21 might be p53independent. In contrast, vanadate slightly increased the level of p21 protein in p53 +/+ cells. The explanation is that vanadate increased the percentage of $\mathrm{S}$ phase instead of change in $\mathrm{G}_{2} / \mathrm{M}$ phase in $\mathrm{p} 53+/+$ cells. The $\mathrm{S}$ phase arrest depended on p53 that was $\mathrm{p} 21-$ dependent. It has been reported that cdc2 is likely to be inhibited by Thr14/Tyr15 phosphorylation which is catalyzed by cdc25, whereas cdk2, which is an important checkpoint of S phase, is likely to be inhibited by association with p21 after UN radiation (53). Probably, a similar mechanism exists in the vandate-induced $\mathrm{S}$ phase arrest in mouse embryo fibroblasts, p53 -/- cells and p53 +/+ cells. The results from our previous study have also demonstrated that vanadate indeed increased p53 protein level, resulting in activation of p21. Both p53 and p21 levels decreased after pretreated with pifithrin- $\alpha$, a specific inhibitor of p53 in JB6 cells (29).

In summary, in p53 -/- cells, vanadate is able to induce $\mathrm{G}_{2} / \mathrm{M}$ phase arrest. It causes degradation of $\operatorname{cdc} 25 \mathrm{C}$ and activation of $\operatorname{cdc} 2$. While it does not alter the expression of p21 and cdc25A. In p53 +/+ cells, vanadate does not change the percentage of cells at $\mathrm{G}_{2} / \mathrm{M}$ phase, but increases the percentage of the cells at $\mathrm{S}$ phase. Vanadate has no effect on cdc 2 or cdc $25 \mathrm{C}$, but it increases p21 level and degrades cdc $25 \mathrm{~A}$. 


\section{III.6. FIGURES}

A

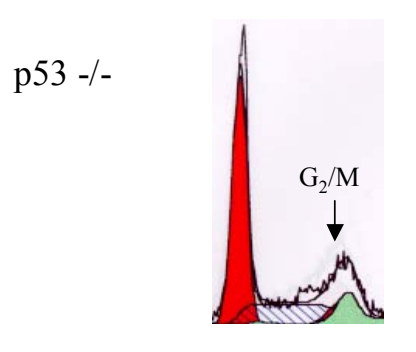

p53 +/+

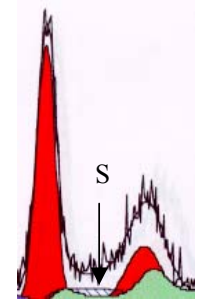

b
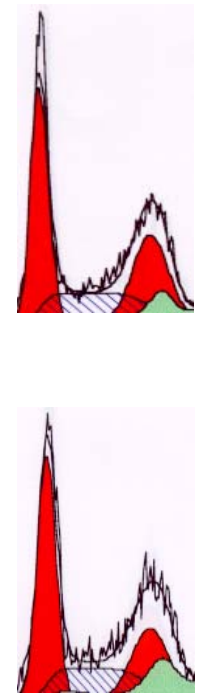

Figure 1 Effects of vanadate on cell growth arrest in both p53 -/- and p53 +/+ cells. p53 +/+ and p53 -/- cells are p53 wild type and p53 deficient mouse embryo fibroblasts, respectively. These two type of cells were incubated in DMEM medium with $5 \%$ FBS in $100 \mathrm{~mm}$ dish. After 80-90\% confluent, the cells were treated with vanadate for different times and different doses. The cells were harvested, and flow cytometry was used to measure DNA content. Panel A shows the profile of cell cycle. a, control without vanadate treatment; $b$, treatment of the cells with $50 \mu \mathrm{M}$ vanadate for $24 \mathrm{~h}$. 


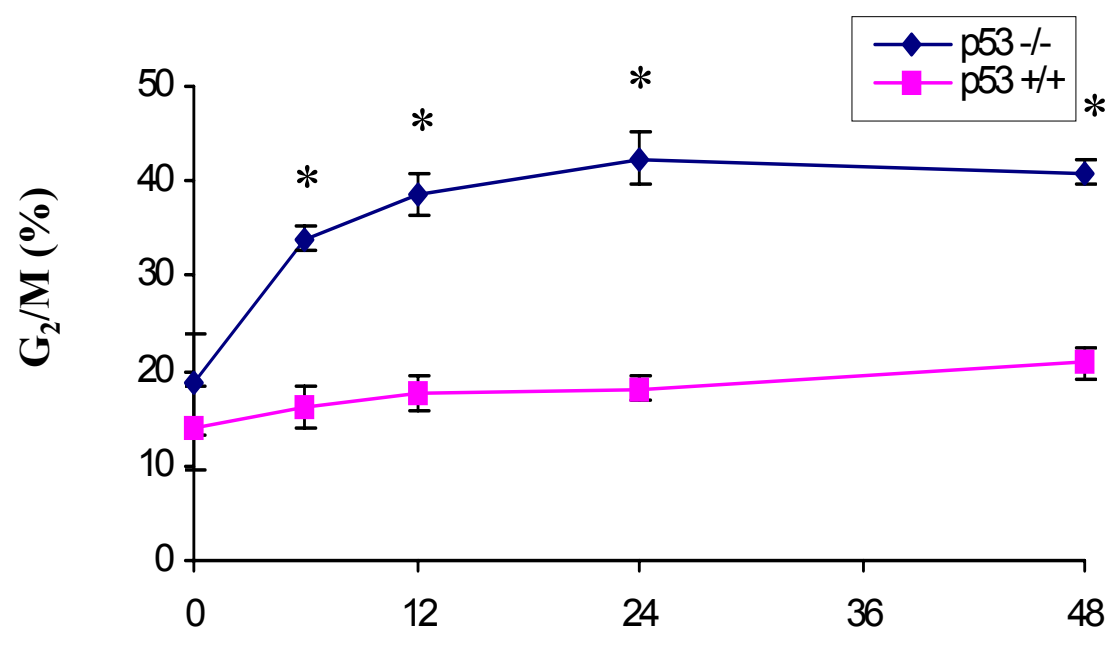

Time (h)

Figure 1 Effects of vanadate on cell growth arrest in both p53 -/- and p53 +/+ cells. p53 +/+ and p53 -/- cells are p53 wild type and p53 deficient mouse embryo fibroblasts, respectively. These two type of cells were incubated in DMEM medium with $5 \%$ FBS in $100 \mathrm{~mm}$ dish. After $80-90 \%$ confluent, the cells were treated with vanadate for different times and different doses. The cells were harvested, and flow cytometry was used to measure DNA content. Panel $B$ represents the time-course of vanadate-induced cell growth arrest at $G_{2} / M$ phase. Each point represents mean $\pm \mathrm{SD}$ of three independent experiments.*, $\mathrm{p}<0.05$ compared to control (one-way ANOVA with the Scheffe's test). 
C

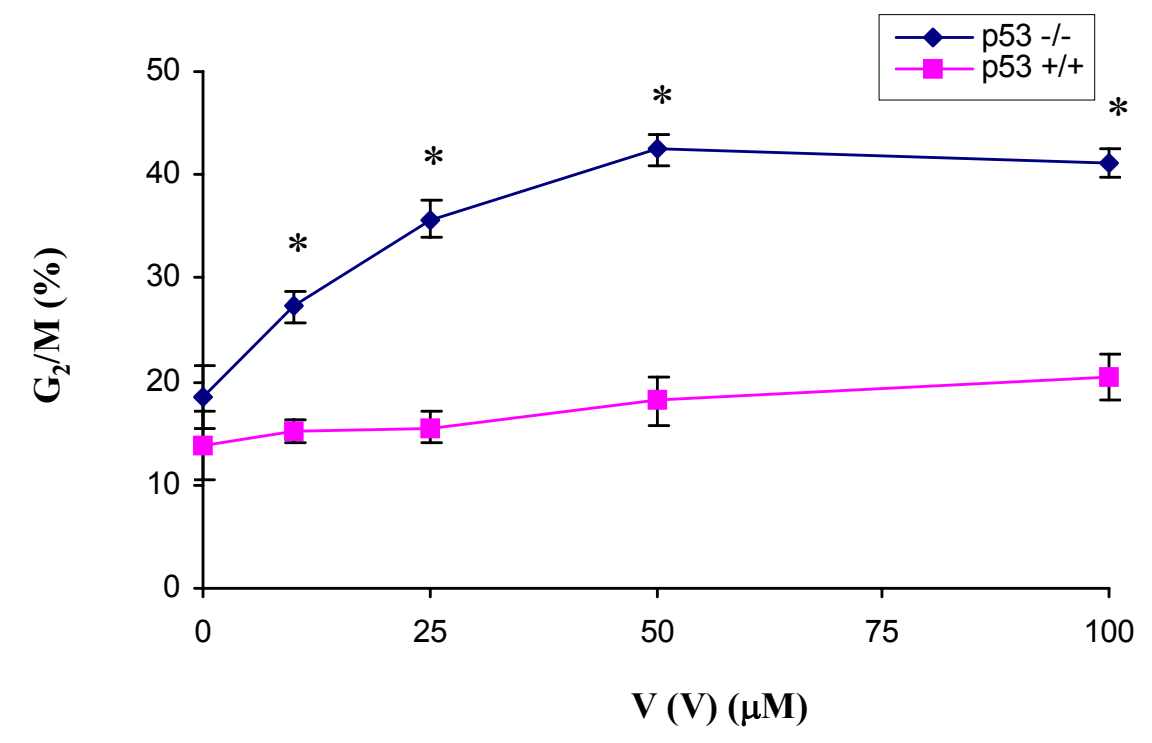

Figure 1 Effects of vanadate on cell growth arrest in both p53 -/- and p53 +/+ cells. p53 +/+ and p53 -/- cells are p53 wild type and p53 deficient mouse embryo fibroblasts, respectively. These two type of cells were incubated in DMEM medium with $5 \%$ FBS in $100 \mathrm{~mm}$ dish. After $80-90 \%$ confluent, the cells were treated with vanadate for different times and different doses. The cells were harvested, and flow cytometry was used to measure DNA content. Panel C represents dose-response of vanadate on cell cycle arrest at $24 \mathrm{~h}$. Each point represents mean $\pm \mathrm{SD}$ of three independent experiments. ${ }^{*}, \mathrm{p}<0.05$ compared to control (one-way ANOVA with the Scheffe's test). 


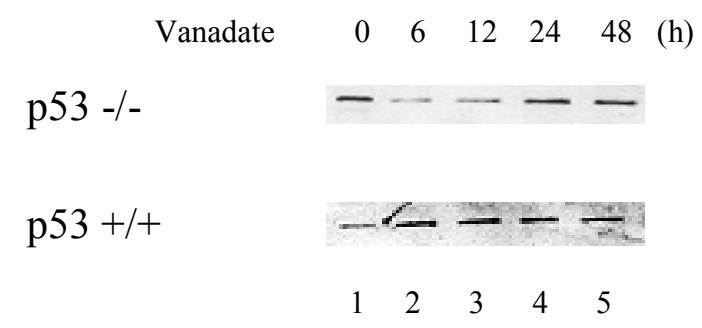

Figure 2 Effects of vanadate on cell growth inhibitory protein p21 in both p53 -/and p53 +/+ cells. The two cells were seeded in 6-well plate. Then the cells were treated with $50 \mu \mathrm{M}$ vanadate for $6 \mathrm{~h}, 12 \mathrm{~h}, 24 \mathrm{~h}$, and $48 \mathrm{~h}$. The whole-cell lysates were collected, and Western blotting was performed to detect the expression of p21. Lane 1, control; lane 2, $6 \mathrm{~h}$; lane 3, $12 \mathrm{~h}$; lane 4, $24 \mathrm{~h}$; and lane 5, $48 \mathrm{~h}$. The concentration of vanadate used was $50 \mu \mathrm{M}$. Data are from a single preparation representative of three indenpend experiments. 


\section{B}

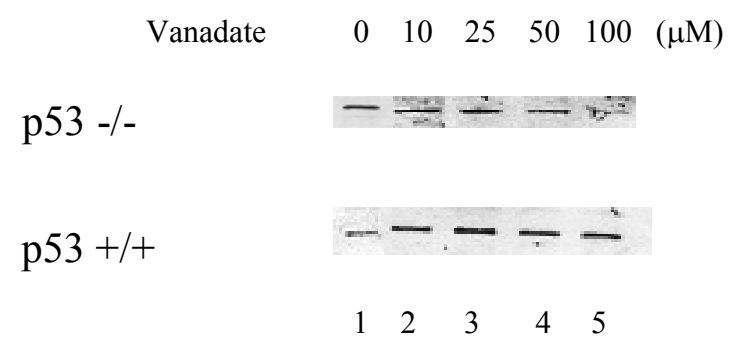

Figure 2 Effects of vanadate on cell growth inhibitory protein p21 in both p53 -/and p53 +/+ cells. The two cells were seeded in 6-well plate. Then the cells were treated with $10 \mu \mathrm{M}, 25 \mu \mathrm{M}, 50 \mu \mathrm{M}$, and $100 \mu \mathrm{M}$ vanadate for $24 \mathrm{~h}$. The whole-cell lysates were collected, and Western blotting was performed to detect the expression of $\mathrm{p} 21$. Lane 1, control; lane 2, 10 $\mu \mathrm{M}$; lane 3, $25 \mu \mathrm{M}$; lane 4, $50 \mu \mathrm{M}$; and lane 5, $100 \mu \mathrm{M}$ vanadate. The incubation time was $24 \mathrm{~h}$. Data are from a single preparation representative of three indenpend experiments. 
A

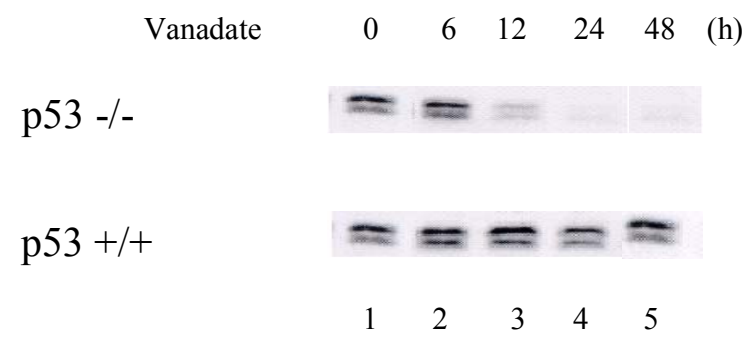

Figure 3 Effects of vanadate on cell growth regulatory protein cdc $25 \mathrm{C}$. The method used is described in detail in the legend to Figure 2. The Western blotting was used to measure cdc25C level. Lane 1, control; lane 2, $6 \mathrm{~h}$; lane 3, $12 \mathrm{~h}$; lane 4, 24 h; and lane 5, $48 \mathrm{~h}$. The concentration of vanadate used was $50 \mu \mathrm{M}$. Data are from a single preparation representative of three indenpend experiments. 
B

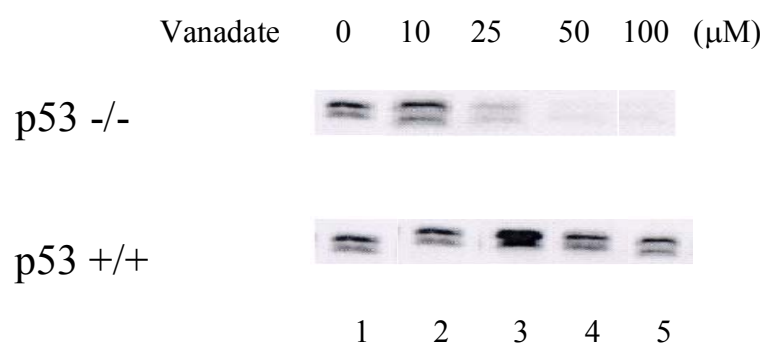

Figure 3 Effects of vanadate on cell growth regulatory protein cdc $25 \mathrm{C}$. The method used is described in detail in the legend to Figure 2. The Western blotting was used to measure cdc25C level. Lane 1, control; lane 2, $10 \mu \mathrm{M}$; lane 3, $25 \mu \mathrm{M}$; lane 4, $50 \mu \mathrm{M}$; and lane 5, $100 \mu \mathrm{M}$ vanadate. The incubation time was $24 \mathrm{~h}$. Data are from a single preparation representative of three indenpend experiments. 
$\mathbf{A}$

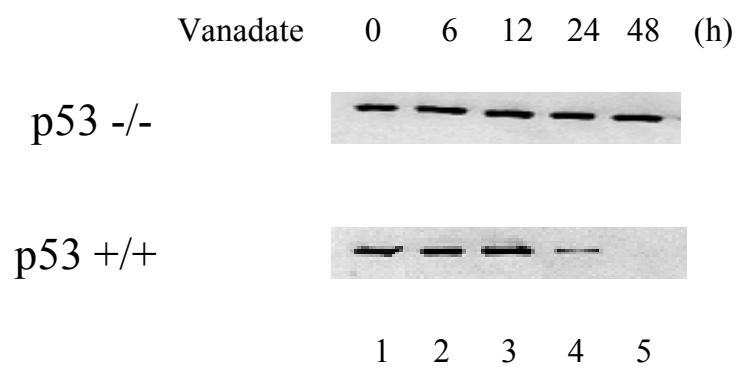

Figure 4 Effects of vanadate on cell growth regulatory protein cdc25A. As described in detail in the legend to Figure 2, Western blotting was conducted to determine the expression of $\operatorname{cdc} 25 \mathrm{~A}$. Lane 1, control; lane 2, $6 \mathrm{~h}$; lane 3, $12 \mathrm{~h}$; lane 4, $24 \mathrm{~h}$; and lane 5, $48 \mathrm{~h}$. The concentration of vanadate used was $50 \mu \mathrm{M}$. Data are from a single preparation representative of three indenpend experiments. 


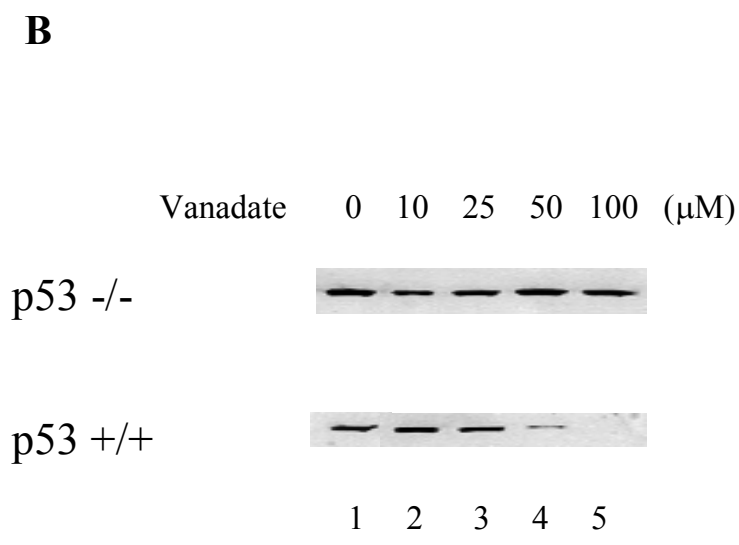

Figure 4 Effects of vanadate on cell growth regulatory protein cdc25A. As described in detail in the legend to Figure 2, Western blotting was conducted to determine the expression of $\operatorname{cdc} 25 \mathrm{~A}$. Lane 1, control; lane 2, $10 \mu \mathrm{M}$; lane 3, $25 \mu \mathrm{M}$; lane 4, $50 \mu \mathrm{M}$; and lane 5, $100 \mu \mathrm{M}$ vanadate. The incubation time was $24 \mathrm{~h}$. Data are from a single preparation representative of three experiments. 
A

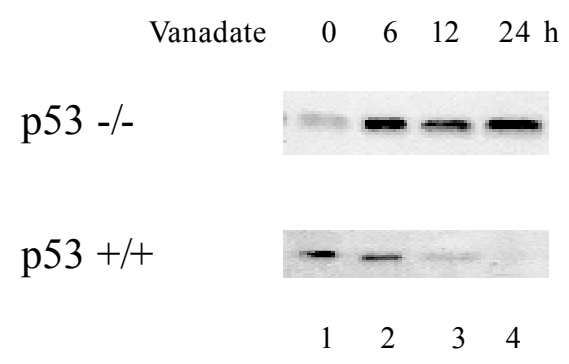

Figure 5 Effects of vanadate on cell cycle checkpoint cdc2. The experimental conditions were the same as these described in the legend to Figure 2. The whole-cell lysates were used to perform Western blotting. Lane 1, control; lane 2, $6 \mathrm{~h}$; lane 3, $12 \mathrm{~h}$; and lane 4, $24 \mathrm{~h}$. The concentration of vanadate used was $50 \mu \mathrm{M}$. Data are from a single preparation representative of three experiments. 
B

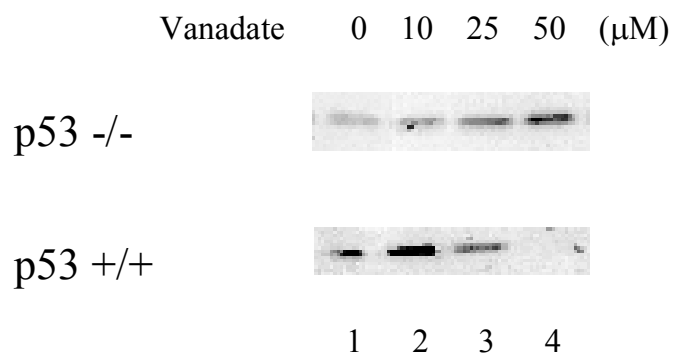

Figure 5 Effects of vanadate on cell cycle checkpoint cdc2. The experimental conditions were the same as these described in the legend to Figure 2. The whole-cell lysates were used to perform Western blotting. Lane 1, control; lane 2, $10 \mu \mathrm{M}$; lane 3, $25 \mu \mathrm{M}$; and lane 4, $50 \mu \mathrm{M}$ vanadate. The incubation time was $24 \mathrm{~h}$. Data are from a single preparation representative of three experiments. 


\section{III.7. REFERENCES}

1. Shackelford, R.E., Kaufmann W.K. and Paules R.S. (1999) Cell cycle control, checkpoint mechanisms, and genotoxic stress. Environ Health Perspect, 107 Suppl 1, 5-24.

2. Paules, R.S., Levedakou E.N., Wilson S.J., Innes C.L., Rhodes N., Tlsty T.D., Galloway D.A., Donehower L.A., Tainsky M.A. and Kaufmann W.K. (1995) Defective G2 checkpoint function in cells from individuals with familial cancer syndromes. Cancer Res, 55, 1763-73.

3. Almog, N. and Rotter V. (1997) Involvement of p53 in cell differentiation and development. Biochim Biophys Acta, 1333, F1-27.

4. Taylor, W.R. and Stark G.R. (2001) Regulation of the G2/M transition by p53. Oncogene, 20, 1803-15.

5. Chan, T.A., Hwang P.M., Hermeking H., Kinzler K.W. and Vogelstein B. (2000) Cooperative effects of genes controlling the $\mathrm{G}(2) / \mathrm{M}$ checkpoint. Genes Dev, 14, 1584-8.

6. Chasteen, N.D. (1983) The Biochemistry of vanadium. Struct Bond, 53, 107-137.

7. Kustin, K., McLeod, G., Gilbert, T.R., Briggs, L.B.R. (1983) Vanadium and other metal ions in the physiological ecilogy of marine organisms. Struc Bond, 53, 139185.

8. Nriagu, J.O. and Pacyna J.M. (1988) Quantitative assessment of worldwide contamination of air, water and soils by trace metals. Nature, 333, 134-9.

9. Boyd, D.W. and Kustin K. (1984) Vanadium: a versatile biochemical effector with an elusive biological function. Adv Inorg Biochem, 6, 311-65.

10. Erdmann, E., Werdan K., Krawietz W., Schmitz W. and Scholz H. (1984) Vanadate and its significance in biochemistry and pharmacology. Biochem Pharmacol, 33, 945-50.

11. Leonard, A. and Gerber G.B. (1994) Mutagenicity, carcinogenicity and teratogenicity of vanadium compounds. Mutat Res, 317, 81-8. 
12. Younes, M. and Strubelt O. (1991) Vanadate-induced toxicity towards isolated perfused rat livers: the role of lipid peroxidation. Toxicology, 66, 63-74.

13. Hickey, R.J., Schoff E.P. and Clelland R.C. (1967) Relationship between air pollution and certain chronic disease death rates. Multivariate statistical studies. Arch Environ Health, 15, 728-38.

14. Stock, P. (1965) On the relations between atmospheric pollution in urban and rural location and mortality from cancer, bronchitis, pneumonia, with particular reference to 3,4-benzopyrene, beryllium, molybdenum, vanadium and arsenic. $\mathrm{Br}$ J Cancer, 14, 397-418.

15. Carpenter, G. (1981) Vanadate, epidermal growth factor and the stimulation of DNA synthesis. Biochem Biophys Res Commun, 102, 1115-21.

16. Hori, C. and Oka T. (1980) Vanadate enhances the stimulatory action of insulin on DNA synthesis in cultured mouse mammary gland. Biochim Biophys Acta, 610, 235-40.

17. Sabbioni, E., Pozzi G., Pintar A., Casella L. and Garattini S. (1991) Cellular retention, cytotoxicity and morphological transformation by vanadium(IV) and vanadium(V) in BALB/3T3 cell lines. Carcinogenesis, 12, 47-52.

18. Smith, J.B. (1983) Vanadium ions stimulate DNA synthesis in Swiss mouse 3T3 and 3 T6 cells. Proc Natl Acad Sci U S A, 80, 6162-6.

19. Nechay, B.R., Nanninga L.B. and Nechay P.S. (1986) Vanadyl (IV) and vanadate (V) binding to selected endogenous phosphate, carboxyl, and amino ligands; calculations of cellular vanadium species distribution. Arch Biochem Biophys, 251, 128-38.

20. Yin, X., Davison A.J. and Tsang S.S. (1992) Vanadate-induced gene expression in mouse C127 cells: roles of oxygen derived active species. Mol Cell Biochem, 115, 85-96.

21. Cruz, T.F., Morgan A. and Min W. (1995) In vitro and in vivo antineoplastic effects of orthovanadate. Mol Cell Biochem, 153, 161-6. 
22. Stern, A., Yin X., Tsang S.S., Davison A. and Moon J. (1993) Vanadium as a modulator of cellular regulatory cascades and oncogene expression. Biochem Cell Biol, 71, 103-12.

23. Swarup, G., Cohen S. and Garbers D.L. (1982) Inhibition of membrane phosphotyrosyl-protein phosphatase activity by vanadate. Biochem Biophys Res Commun, 107, 1104-9.

24. Ding, M., Li J.J., Leonard S.S., Ye J.P., Shi X., Colburn N.H., Castranova V. and Vallyathan V. (1999) Vanadate-induced activation of activator protein-1: role of reactive oxygen species. Carcinogenesis, 20, 663-8.

25. Ye, J., Ding M., Zhang X., Rojanasakul Y., Nedospasov S., Vallyathan V., Castranova V. and Shi X. (1999) Induction of TNFalpha in macrophages by vanadate is dependent on activation of transcription factor NF-kappaB and free radical reactions. Mol Cell Biochem, 198, 193-200.

26. Huang, C., Zhang Z., Ding M., Li J., Ye J., Leonard S.S., Shen H.M., Butterworth L., Lu Y., Costa M., Rojanasakul Y., Castranova V., Vallyathan V. and Shi X. (2000) Vanadate induces p53 transactivation through hydrogen peroxide and causes apoptosis. J Biol Chem, 275, 32516-22.

27. Huang, C., Ding M., Li J., Leonard S.S., Rojanasakul Y., Castranova V., Vallyathan V., Ju G. and Shi X. (2001) Vanadium-induced nuclear factor of activated T cells activation through hydrogen peroxide. J Biol Chem, 276, 22397403.

28. Ye, J., Ding M., Leonard S.S., Robinson V.A., Millecchia L., Zhang X., Castranova V., Vallyathan V. and Shi X. (1999) Vanadate induces apoptosis in epidermal JB6 P+ cells via hydrogen peroxide-mediated reactions. Mol Cell Biochem, 202, 9-17.

29. Zhang, Z., Huang C., Li J., Leonard S.S., Lanciotti R., Butterworth L. and Shi X. (2001) Vanadate-induced cell growth regulation and the role of reactive oxygen species. Arch Biochem Biophys, 392, 311-20. 
30. Nicoletti, I., Migliorati, G., Pagliacci, M.C., Grignani, F. and Riccardi, C. (1991) A rapid and simple method for measuring thymocyte apoptosis by propidium iodide staining and flow cytometry. J Immunol Methods, 139, 271-279.

31. Sgonic, R.a.W., G (1994.) Methods for the detection of apoptosis. Int Arch Allergy Immunol, 105, 327-332.

32. Irani, K., Xia Y., Zweier J.L., Sollott S.J., Der C.J., Fearon E.R., Sundaresan M., Finkel T. and Goldschmidt-Clermont P.J. (1997) Mitogenic signaling mediated by oxidants in Ras-transformed fibroblasts. Science, 275, 1649-52.

33. Morgan, D.O. (1995) Principles of CDK regulation. Nature, 374, 131-4.

34. Ye, J., Wang S., Leonard S.S., Sun Y., Butterworth L., Antonini J., Ding M., Rojanasakul Y., Vallyathan V., Castranova V. and Shi X. (1999) Role of reactive oxygen species and p53 in chromium(VI)-induced apoptosis. $J$ Biol Chem, 274, 34974-80.

35. Kastan, M.B., Onyekwere O., Sidransky D., Vogelstein B. and Craig R.W. (1991) Participation of p53 protein in the cellular response to DNA damage. Cancer Res, 51, 6304-11.

36. Chen, F., Zhang Z., Leonard S.S. and Shi X. (2001) Contrasting roles of NFkappaB and JNK in arsenite-induced p53-independent expression of GADD45alpha. Oncogene, 20, 3585-9.

37. Thompson, D.A., Belinsky G., Chang T.H., Jones D.L., Schlegel R. and Munger K. (1997) The human papillomavirus-16 E6 oncoprotein decreases the vigilance of mitotic checkpoints. Oncogene, 15, 3025-35.

38. Avantaggiati, M.L., Carbone M., Graessmann A., Nakatani Y., Howard B. and Levine A.S. (1996) The SV40 large T antigen and adenovirus E1a oncoproteins interact with distinct isoforms of the transcriptional co-activator, p300. EMBO J, 15, 2236-48.

39. Chang, T.H., Ray F.A., Thompson D.A. and Schlegel R. (1997) Disregulation of mitotic checkpoints and regulatory proteins following acute expression of SV40 large $\mathrm{T}$ antigen in diploid human cells. Oncogene, 14, 2383-93. 
40. Eckner, R., Ludlow J.W., Lill N.L., Oldread E., Arany Z., Modjtahedi N., DeCaprio J.A., Livingston D.M. and Morgan J.A. (1996) Association of p300 and CBP with simian virus 40 large T antigen. Mol Cell Biol, 16, 3454-64.

41. Powell, S.N., DeFrank J.S., Connell P., Eogan M., Preffer F., Dombkowski D., Tang W. and Friend S. (1995) Differential sensitivity of p53(-) and p53(+) cells to caffeine-induced radiosensitization and override of G2 delay. Cancer Res, 55, 1643-8.

42. Pines, J. and Hunter T. (1989) Isolation of a human cyclin cDNA: evidence for cyclin mRNA and protein regulation in the cell cycle and for interaction with p34cdc2. Cell, 58, 833-46.

43. Faure, R., Vincent M., Dufour M., Shaver A. and Posner B.I. (1995) Arrest at the G2/M transition of the cell cycle by protein-tyrosine phosphatase inhibition: studies on a neuronal and a glial cell line. J Cell Biochem, 59, 389-401.

44. Kaufmann, W.K., Levedakou E.N., Grady H.L., Paules R.S. and Stein G.H. (1995) Attenuation of G2 checkpoint function precedes human cell immortalization. Cancer Res, 55, 7-11.

45. Chin, L.S., Murray S.F., Harter D.H., Doherty P.F. and Singh S.K. (1999) Sodium vanadate inhibits apoptosis in malignant glioma cells: a role for Akt/PKB. $J$ Biomed Sci, 6, 213-8.

46. Strausfeld, U., Labbe J.C., Fesquet D., Cavadore J.C., Picard A., Sadhu K., Russell P. and Doree M. (1991) Dephosphorylation and activation of a p34cdc2/cyclin B complex in vitro by human CDC25 protein. Nature, 351, 242-5.

47. Brown, A.L., Lee C.H., Schwarz J.K., Mitiku N., Piwnica-Worms H. and Chung J.H. (1999) A human Cds1-related kinase that functions downstream of ATM protein in the cellular response to DNA damage. Proc Natl Acad Sci U S A, 96, 3745-50.

48. Peng, C.Y., Graves P.R., Thoma R.S., Wu Z., Shaw A.S. and Piwnica-Worms H. (1997) Mitotic and G2 checkpoint control: regulation of 14-3-3 protein binding by phosphorylation of Cdc25C on serine-216. Science, 277, 1501-5. 
49. Sanchez, Y., Wong C., Thoma R.S., Richman R., Wu Z., Piwnica-Worms H. and Elledge S.J. (1997) Conservation of the Chk1 checkpoint pathway in mammals: linkage of DNA damage to Cdk regulation through Cdc25. Science, 277, 1497501.

50. $\quad$ el-Deiry, W.S., Tokino T., Velculescu V.E., Levy D.B., Parsons R., Trent J.M., Lin D., Mercer W.E., Kinzler K.W. and Vogelstein B. (1993) WAF1, a potential mediator of p53 tumor suppression. Cell, 75, 817-25.

51. Harper, J.W., Adami G.R., Wei N., Keyomarsi K. and Elledge S.J. (1993) The p21 Cdk-interacting protein Cip1 is a potent inhibitor of G1 cyclin-dependent kinases. Cell, 75, 805-16.

52. Xiong, Y., Hannon G.J., Zhang H., Casso D., Kobayashi R. and Beach D. (1993) p21 is a universal inhibitor of cyclin kinases. Nature, 366, 701-4.

53. Poon, R.Y., Jiang W., Toyoshima H. and Hunter T. (1996) Cyclindependent kinases are inactivated by a combination of p21 and Thr-14/Tyr15 phosphorylation after UV-induced DNA damage. J Biol Chem, 271, 13283-91. 


\section{SECTION IV}

MAPKs Mediate S Phase Arrest Induced by Vanadate through a p53

Dependent Pathway in Mouse Epidermal C141 Cells 


\section{IV.1. ABSTRACT}

Mitogen-activated protein kinases (MAPKs) play an important role in mediation of signal transduction pathway in cellular response to genotoxic stress. Cell growth arrest is considered as an early stage in response to the genotoxic stress. p53 is well known as a tumor suppression gene involved in both cell growth arrest and apoptosis. The present study investigated the involvement of MAPKs in vanadate-induced cell growth arrest and the relationship of p53. DNA content analysis showed that vanadate induced S phase arrest is time- and dose-dependent in p53 wild type C141 cells but not in p53 deficient C141 cells. Western blotting results indicated that vanadate caused an inactivation of pcdk2 at Thr160, which is an important kinase for the progression of S phase, and an increase in expression of $\mathrm{p} 21$, which is a key for S phase arrest. In p53 deficient cells, vanadate did not induce any observable change in p21 or p-cdk2 level. In addition, vanadate up-regulated phospho-p38 and ERK, two members of MAP kinases. At the same time, vanadate increased the p53 activity as measured by luciferase assay. Addition of PD98059 and SB202190, inhibitors of ERK and p38, respectively, decreased vanadateinduced S phase arrest, reduced p21 level, restored activation of p-cdk2, and decreased p53 activity. The study demonstrated that vanadate-induced $\mathrm{S}$ phase arrest is mediated by both ERK and p38 in p53-dependent pathway. 


\section{IV.2. INTROUCTION}

Exposure of cells to genotoxic agents evokes a series of events leading to the activation of a wide spectrum of genes with diverse functions. A number of transcription factors as well as various gene products are involved in response to mitogenic stimulation, illustrating that signal transduction pathways are involved in mediating the cellular response to stress and proliferative signals (19).

The mitogen-activated protein kinases (MAPKs) pathway has a central role in cellular signaling (20). MAPKs include three major components which are extracellular signal-regulated kinases (ERK), stress activated protein kinases (SAPK)/c-Jun N-terminal kinases (JNK), and p38/RK/CSBP kinases. These kinases play a key role in the activation of transcription factors and other regulatory proteins involved in activating gene expression (8). A common feature of MAPKs is their activation through phosphorylation of threonine and tyrosine residues in a homogenous kinase subdomain VIII (8). Upon activation, MAPKs translocate into the nucleus where they phosphorylate transcription factors and thereby alter gene transcription patterns $(6,26)$. Over-activation of these protein kinases can lead to uncontrolled cell growth and tumorigenesis (28).

ERK is one of the most characterized signaling pathways that connect different types of membrane receptors to the nucleus after mitogenic stimulation $(12,44)$ or differentiation (32). The activation of ERK involves the activation of low-molecularweight GTP-bonding proteins (Ras) at the plasma membrane and the sequential activation of a series of protein kinases: a MAPK kinase kinase (Raf-1) is activated and then by phosphorylation it activates a MAPK kinase (MEK1/2), which in turns phosphorylates ERK on threonine and tyrosine residues, leading to ERK activation (53). ERK is able to phosphorylate cytoplasmic and nuclear targets $(16,29)$. This pathway has been found to

play a critical role in the control of cell proliferation via growth factor receptors and integrins (22). p38, another important member of MAPKs, is involved in inflammation, 
cell differentiation, cell cycle regulation, and cell death (38). p38 pathway shares many similarities with other MAP kinase cascades. Similar to other MAPKs, p38 is activated by dual kinase, the MAP kinase kinase (MKK). Besides the same pathway as the ERK in Ras/Raf/MEK/MAPK, the Rho family, Rac and cdc42 were also identified as potential regulators of the $\mathrm{p} 38$ pathway $(4,40,57)$.

The $\mathrm{p} 53$ tumor suppressor protein appears to serve numerous functions during the cellular response to genotoxic stress, some of which act as a transcription factor to activate gene expression (20). p53 is considered an important mediator in the cell cycle. Various kinases including double-stranded DNA-activated protein kinase (DNA-PK), cyclin A and cyclin B-associated kinase cdc2, ERK and JNK have been implicated in p53 phosphorylation that in turn participates in regulation of p53 activity $(2,33,34)$.

Vanadate is an essential trace element. It is widely found in occupational and environmental systems. Epidemiological studies have shown a correlation between vanadium exposure and the incidence of lung cancer in humans $(21,37,42)$. Vanadium compounds were reported to modify DNA synthesis and repair $(9,21,42)$, induced mutations and DNA-protein crosslinks $(9,18,30,49,59)$. Vanadate is able to induce $\mathrm{G}_{2} / \mathrm{M}$ phase arrest through MAPKs pathway mediated by reactive oxygen species (ROS) in A549 cells. A study from our group also indicated that vanadate caused p53 dependent $\mathrm{S}$ phase arrest in mouse epidermal C141 cells.

The purposes of the present study are: 1) to examine of effects of vanadate on MAPKs; 2) to understand the relationship between MAPKs and cell growth arrest induced by vanadate; and 3) to investigate the role of p53 in vanadate-induced cell growth arrest. 


\section{IV.3. MATERIALS AND METHODS}

Reagents Sodium metavanadate was purchased from Aldrich (Milwaukee, WI). Dulbecco's modified eagle medium (DMEM) and Eagle's minimal essential medium (MEM) were from Sigma (St. Louis, MO). Fetal bovine serum (FBS) was from Gibco BRL (Life Technologies, Gaithersburg, MD). Antibody against p21 was from Santa Cruz Biotechnology (Santa Cruz, CA). Antibodies against phospho-cdk2, p38 and ERK, and secondary AP linked anti-rabbit IgG were from Cell Signaling (Beverly, MA).

Cell culture The JB6 $\mathrm{P}^{+}$mouse epidermal cell line, C141 cells were stably transfected with p53 luciferase reporter, and cultured in MEM medium containing 5\% FBS, $2 \mathrm{mM} \mathrm{L}$-glutamine and $1000 \mathrm{U} / \mathrm{ml}$ penicillin-streptomycin in an incubator at 5\% $\mathrm{CO}_{2}$ and $37^{\circ} \mathrm{C}$.

Determination of lactate dehydrogenase leakage Activity of lactate dehydrogenase (LDH) leakage was measured using an FARA Chemical Analyzer with the test kit (Roche, Gaithersburg, MD). The total LDH activity was measured after cells were disrupted using ultrasonication. LDH leakage (\%) was calculated as LDH activity in medium/total LDH activity x 100 .

Measurement of cell cycle/DNA content DNA content in $\mathrm{G}_{1}, \mathrm{~S}$ and $\mathrm{G}_{2} / \mathrm{M}$ phase was analyzed using flow cytometry $(39,45)$. Cells were fixed and permeabilized with $70 \%$ ethanol for more than $2 \mathrm{~h}$, and then incubated with the freshly prepared staining buffer $(0.1 \%$ Triton X-100, $200 \mu \mathrm{g} / \mathrm{ml}$ RNase A, and $20 \mu \mathrm{g} / \mathrm{ml} \mathrm{PI})$ for $30 \mathrm{~min}$ at room temperature. For flow cytometric analysis, at least 10,000 cells were used in each sample. The DNA content histogram was abstracted and the percentage of cells in S phase was calculated using ModFit LT software. 
Western blotting analysis Whole cell extracts were mixed with Tris-Glycine SDS sample buffer and then performed Tris-Glycine gel electrophoresis. The resolved proteins were transferred to PVDF membrane. Western blotting was performed using antibodies against p21, phospho-cdk2 at Thr160, ERK and p38, and secondary anti-rabbit IgG. After reaction with ECF substrate, the signal was detected using a Storm Scanner (Molecular Dynamics, Sunnyvale, CA).

Luciferase assay for p53 activity After C141 cells were 80-90\% confluent, $1 \times 10^{4}$ cells were placed into a 96-well plate with $100 \mu$ MEM medium in each well. The cells were treated by vanadate with different times and doses. At various time points, the cells were extracted with lysis buffer. The p53 luciferase activity was measured using a luminometer (moonlight 3010). The results were expressed as p53 activity relative to the control.

Statistical analysis All data were based on at least three independent experiments. Relative p53 activity was presented as means \pm SD and analyzed using oneway ANOVA with the Scheffe's test. A $p$ value less than 0.05 was considered statistically significant. 


\section{IV.4. RESULTS}

Toxicity of vanadate The toxicity of vanadate in C141 cells was examined by measuring LDH leakage. Figure 1A shows that at concentrations up to $100 \mu \mathrm{m}$ for an incubation time of $24 \mathrm{~h}$ vanadate did not exhibit any significant toxicity. No significan toxicity was observed for $50 \mu \mathrm{M}$ vanadate incubation times up to $48 \mathrm{~h}$ (Figure 1B). These results indicate that at the concentrations used in the present study, vanadate did not cause any significant toxic effect.

Effects of vanadate on cell cycle To study the effects of vanadate on cell growth arrest in C141 cells, flow cytometry was performed to analyze DNA content. Figure 2 shows that vanadate caused time-dependent increase at S phase in C141 cells. The percentage of cells at S phase was $14.40 \%$ in $50 \mu \mathrm{M}$ vanadate-treated C141 cells for $6 \mathrm{~h}$ (b) instead of $8.02 \%$ in control without stimulation (a). The percentage of cells at $\mathrm{S}$ phase attained the highest $(30.03 \%)$ at $24 \mathrm{~h}$ treatment (d). The results from dose-dependent study are shown in Figure 3. In this study, C141 cells were treated with 10, 25, 50, and $100 \mu \mathrm{M}$ vanadate for $24 \mathrm{~h}$. The percentage of the cells at $\mathrm{S}$ phases was $13.35 \%, 18.45 \%$, 30.03 and $25.82 \%$ when the cells were treated with $10 \mu \mathrm{M}, 25 \mu \mathrm{M}, 50 \mu \mathrm{M}$, and $100 \mu \mathrm{M}$ vanadate, respectively. In contrast, in p53 -/- cells, the percentage of the cells at S phases remained at the control levels regardless vanadate treatment times or doses (data not shown).

Effects of vanadate on cell growth regulatory proteins Western blotting was used to examine the effects of vanadate on proteins p21 and p-cdk2. Protein p21 is an important kinase for $\mathrm{S}$ phase arrest while $\mathrm{p}$-cdk2 for $\mathrm{S}$ phase progression. In p53 deficient cells, vanadate did not induce a significant alternation in p21 or p-cdk2 level (data not shown). In C141 cells, vanadate caused an increase in p21 level with peak at $25 \mu \mathrm{M}$ 
(Figure 4). At the same time, vanadate inactivated phosphorylation of p-cdk2 at Thr160 in a time- and dose-dependent manner.

Effects of vanadate on ERK and p38 Western blotting was performed to study the effects of vanadate on ERK and p38. As shown in Figure 5, lanes 1 and 2, vanadate at 50 $\mu \mathrm{M}$ caused phosphorylation of both ERK and p38. An increase in incubation time enhanced the phosphorylation (lanes 3 to 6). Vanadate-induced ERK and p38 phosphorylation was also dose-depedent (lanes 7 to 11).

Effects of vanadate on p53 activity Luciferase assay was used to determine the p53 activity in C141 cells. Vanadate-induced increase in p53 activity was time dependent as shown in Table 1. When the C141 cells were treated with $50 \mu \mathrm{M}$ vanadate for $6 \mathrm{~h}$, the p53 activity increased 1.5-fold compared to the control. The relative p53 activity increased from 1.5-fold to 6-fold when vanadate treatment time was elongated from $6 \mathrm{~h}$ to $48 \mathrm{~h}$. Vanadate treatment also caused a dose-dependent increase in p53 activity (Table 2). It was about 5-fold when cells were treated with $100 \mu \mathrm{M}$ vanadate for $24 \mathrm{~h}$.

Effects of MAPKs inhibitors on MAPKs PD98059, an inhibitor of ERK, and SB202190, an inhibitor of p38, were used to determine their effects on vanadate-induced upregulaton of MAPKs. Figure 6 showed that treatment of the cells with $50 \mu \mathrm{M}$ or 100 $\mu \mathrm{M}$ PD98059 almost abolished vanadate-induced elevation of p-ERK (lanes 3 and 4). In contrast, SB 202190 had no effect on p-ERK (lanes 5-6). Pretreatment of the cells with 5 $\mu \mathrm{M}$ or $10 \mu \mathrm{M}$ SB202190 dramatically decreased of p-p38 as expected. PD 98059 did not inhibit it.

Effects of MAPKs cell growth arrest As shown in Figure 7, for untreated C141 cells, the percentage of cells at S phase was $8.02 \%$ (a). Treatment of the cells with $50 \mu \mathrm{M}$ vanadate for $24 \mathrm{~h}$ increased the $\mathrm{S}$ phase percentage to 30.02 (b). Pretreatment with ERK 
inhibitor, PD98059 decreased the percentage of the C141 cells at S phase to $11.86 \%$ at 50 $\mu \mathrm{M}$ and $8.92 \%$ at $100 \mu \mathrm{M}$ (c and d). Similarly, addition of $5 \mu \mathrm{M}$ or $10 \mu \mathrm{M}$ SB202190, the percentage of the cells at S phase was $16.95 \%$ or $14.97 \%$ (e and f). The results show that inhibition of ERK or $\mathrm{p} 38$ decreases $\mathrm{S}$ phase arrest in vanadate-treated $\mathrm{C} 141$ cells.

Effects of MAPKs cell growth regulatory proteins As expected, pretreatment of C141 cells with PD98059 or SB202190 decreased vanadate-induced p21 level compared to the vanadate treatment alone (Figure 8). The amount of proteins was almost at the same level as the control without stimulation. Pretreatment of the cells with these two inhibitors restored vanadate-inactivated p-cdk2.

Effects of MAPKs on p53 activity As shown in Table 3, $50 \mu \mathrm{M}$ vanadate caused 3.7 -fold increase in p53 activity. The relative p53 activity was sharply decreased when C141 cells were incubated with $50 \mu \mathrm{M}$ and $100 \mu \mathrm{M}$ PD98059, respectively. Similarly, pretreatment with SB also decreased the p53 activity. 


\section{IV.5. DISCUSSION}

Vanadate compounds exhibit potent toxic and carcinogenic effects on various biological systems. It is able to modify DNA synthesis and repair $(9,21,42,48)$, induce mutation and DNA-protein crosslinks (37), and inhibit tyrosine phosphatase, and autophosphorylate tyrosine kinase on the cell membrane receptor (56). It has been reported that vanadate caused DNA damage (46), and activated certain transcription factors, such as AP-1 (13), NF- $\mathrm{B}$ (55), p53 (25), and nuclear factor of activated T cells (NFAT) (23). It has also been reported that vanadate is able to induce apoptosis and cell growth arrest $(25,54,58)$. Our laboratory has shown that vanadate caused $\mathrm{G}_{2} / \mathrm{M}$ phase arrest through ROS-mediated reactions. The detailed mechanisms of signal transduction pathway involved in vanadate-induced cell growth arrest are still unclear. The results from present study show that: 1) vanadate caused S phase arrest in C141 cells in a timeand dose-dependent manner but not in p53 deficient cells; 2) vanadate up-regulated p21 and decreased p-cdk2;3) it activated two important members of MAPK family, ERK and p38; 4) vanadate increased p53 activity; 5) vanadate induced $S$ phase arrest was decreased by inhibition of either ERK or p38; 6) inhibition of MAPKs decreased vanadate-induced p21 and restored activation of $\mathrm{p}-\mathrm{cdk} 2$; and 7) inhibition of MAPKs reduced vanadate-induced $\mathrm{p} 53$ activity.

Cellular stress, particularly that involving damage to the cell's replicative machinery, causes delay in cell cycle progression in virtually all living organisms. The cell cycle delay or arrest is considered important after DNA damage, since this delay or arrest allows the cells time to recover and/or repair damaged DNA prior to replication and mitosis. Earlier studies have shown that vanadate caused $\mathrm{G}_{2} / \mathrm{M}$ arrest in T98 glioma

cells, and both $\mathrm{p} 34^{\mathrm{cdc} 2}$ and cdc25C participated in the regulation of growth arrest at this phase $(11,14)$. The results from our laboratory also indicated that vanadate caused $\mathrm{G}_{2} / \mathrm{M}$ 
phase arrest in A549 cells through ROS-mediated reactions (58). The present study shows that vanadate induced S phase arrest in C141 cells.

Cell cycle checkpoints monitor movement through the cell cycle, survey for cell damage, and induce a pause in cell cycle progression when necessary. Cyclins and cyclin-dependent kinases (cdks) are key regulators of the eukaryotic cell cycle (41). Cdk2 is associated with cyclin $\mathrm{A}$ and cyclin $\mathrm{E}$, and the respective complexes are believed to control $S$ phase and the $G_{1} / S$ transition (17). The activity of cdk2 is regulated by an intricate system of protein-protein interaction and phosphorylation. The activity of this kinase is increased by phosphorylation of Thr160 and inhibited by phosphorylation of Thr14 and Tyr15. The activity of cdk2 is also negatively regulated by its binding to protein inhibitors. One of the important inhibitors is $\mathrm{p} 21$, which is downstream protein of p53. In addition to inhibiting the kinase activity by binding to the complex, p21 also blocks the phosphorylation of the activating threonine residue in cdks (3). It has been reported that p21 is probably sufficient for the inhibition of cdk2 (41). The results from present study showed that in C141 cells vanadate indeed decreased phosphorylation of cdk2 at Thr160. In the p53 -/- cells, vanadate treatment did not alter the percentage of the cells at S phase, and both p21 and p-cdk2 remained the same levels as the control without vanadate stimulation (data not shown).

MAPKs play a pivotal role in the regulation of cell growth arrest, survival, differentiation, and apoptosis $(15,36)$. Once they are activated, MAPKs regulate gene expression through phosphorylation of downstream transcription factors. Generally, activation of ERK cascade is involved in mitogenesis and differentiation, whereas both p38 and JNK are believed to mediate cell growth arrest and apoptosis $(15,36)$. In Xenopus egg, ERK is activated during the cells arrested in $M$ phase. Addition of PD98059 decreased the M phase arrest (5). Another study showed that PD98059 reverted the $\mathrm{G}_{1}$ phase arrest as well as $\mathrm{pRB}$ hyperphosphorylation induced by the growth inhibition agent TPA (1). Furthermore, inhibition of ERK kinase activity substantially 
abrogates the UV induction of the GADD45 promoter that is important checkpoint responsible for $\mathrm{G}_{2} / \mathrm{M}$ phase arrest (52). The results from our laboratory also showed that ERK was involved in vanadate-induced $\mathrm{G}_{2} / \mathrm{M}$ phase arrest (unpublished observation). In contrast, a previous study also found that persistently activated ERK may cause unregulated growth of fibroblasts and tumor formation in mice (31). The inhibition of ERK activity induced a dose-dependent growth arrest in $\mathrm{G}_{0} / \mathrm{G}_{1}$ phase with upregulation of cdk2 and hypophosphorylation of RB (27). The present study showed that vanadate activated phosphorylation of ERK as early as $0.5 \mathrm{~h}$. Addition of PD98059 not only decreased vanadate-induced S phase arrest, but also reduced the p21 level and restored pcdk2 inactivated by vanadate, suggesting that ERK is involved in vanadate-induced $\mathrm{S}$ phase arrest in C141 cells. In addition, the importance of p38 in cell growth became apparent due to the observation that overexpression of $\mathrm{p} 38$ in yeast led to significant decrease in proliferation (60). The p38 was activated in cultured mammalian cells when these cells were arrested in M phase by disruption of the spindle with nocodazole (50). Activation of p38 is also believed to be involved in the spindle assembly checkpoint of somatic cell cycles (35). $\mathrm{G}_{1}$ arrest in NIH3T3 cells caused by microinjection of cdc42 is p38-dependent (35). Disruption of fission yeast p38 cascades, Wis1-Spc/Sty1, lead to cell size enlargement and cell division arrest, suggesting that the Wis1-Spac1 MAPK cascade is linked to the $\mathrm{G}_{2} / \mathrm{M}$ cell cycle control mechanism (47). The regulation of cdc25B phosphorylation by p38 is a critical event for initiating the $\mathrm{G}_{2} / \mathrm{M}$ phase checkpoint after UV exposure (7). The present study indicates that p38 was activated by the vanadate treatment in a time- and dose-dependent manner. Inhibition of p38 phosphorylation by SB202190 decreased vanadate-induced S phase arrest. Similarly, p38 is also involved in vanadate-regulated protein $\mathrm{p} 21$ and p-cdk2.

p53 mediates several cellular functions such as induction of cell cycle arrest or apoptosis in response to DNA damage and helps to preserve genetic stability (51). It has been reported that p53-dependent cell growth arrest in $G_{1}$ phase is an important component of the cellular response to stress (51). A recent study indicates that p53 
controls the entry into mitosis when cells enter $\mathrm{G}_{2}$ phase with damaged DNA or when they are arrested in $\mathrm{S}$ phase due to depletion of the substrates required for DNA synthesis (10). It has been reported that activation of p53 following DNA damage induces expression of $\mathrm{p} 21$, which in turn may be responsible for the cell cycle arrest (41). In addition, inhibition of either ERK or p38 decreased the p53 activity induced by vanadate. The p53 activation correlated with prominent activation of ERK1/2 MAP kinases that resulted from colcemid-stimulated development of focal adhesions that caused $\mathrm{G}_{1}$ phase arrest (43). It has also been reported that phosphorylation of $\mathrm{p} 53$ by $\mathrm{p} 38$ plays a role in p53-dependent transcription (24).

In summary, vanadate induced S phase arrest in p53 wild type C141 cells, upregulated p21, and inactivated cdk2. Vanadate caused activation of both ERK and p38. Vanadate also increased p53 activity. The inhibition of either ERK or p38 decreased vanadate-induced S phase arrest, reduced p21 level and p53 activity, and increased phophorylation of cdk2. The present study indicates that vanadate-induced S phase arrest is mediated by MAPKs through p53-dependent pathway. 


\section{IV.6. FIGURES}

A

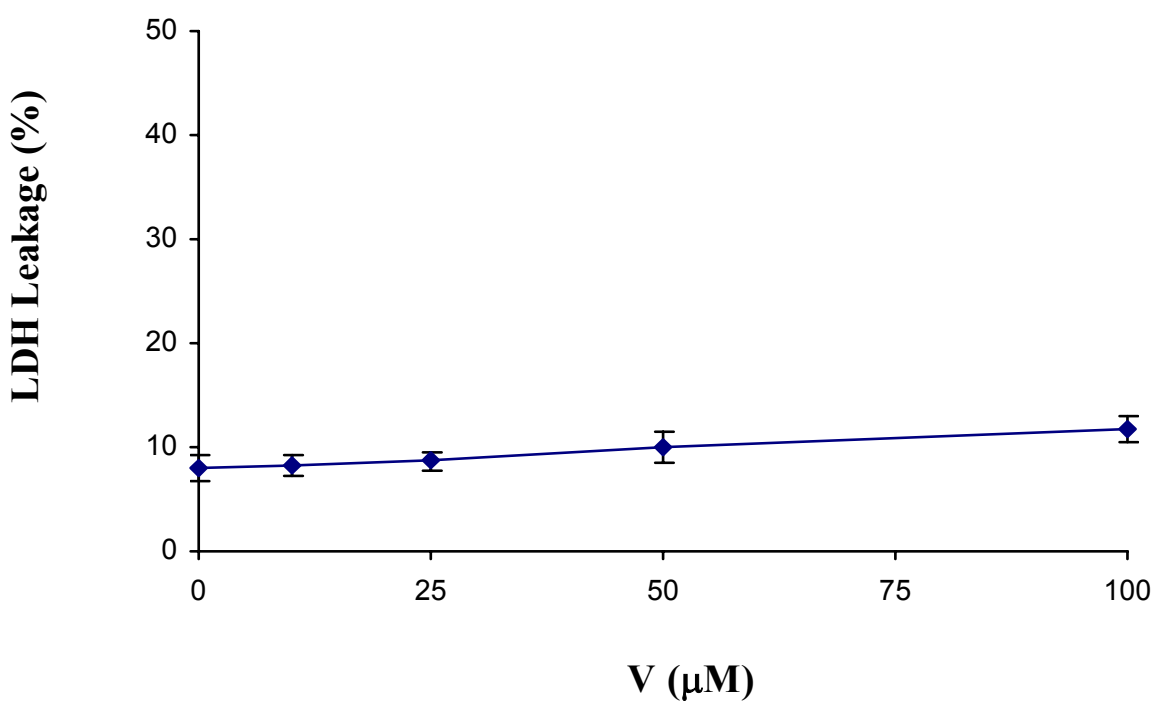

Figure 1 Leakage of cytosolic lactate dehydrogenase (LDH) from C141 cells exposed to various concentrations of vanadate for $24 \mathrm{~h}$. Each point represents mean $\pm \mathrm{SD}$ of three independent experiments. 


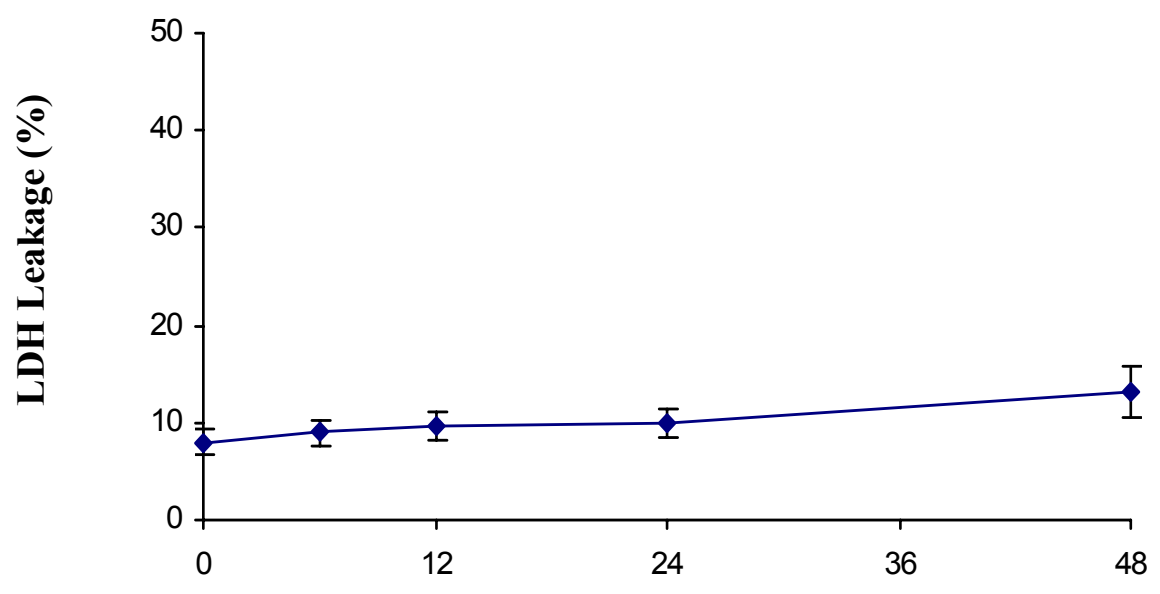

Time (h)

Figure 1 Leakage of cytosolic lactate dehydrogenase (LDH) from C141 cells exposed to to $50 \mu \mathrm{M}$ vanadate for various times. Each point represents mean $\pm \mathrm{SD}$ of three independent experiments. 
a
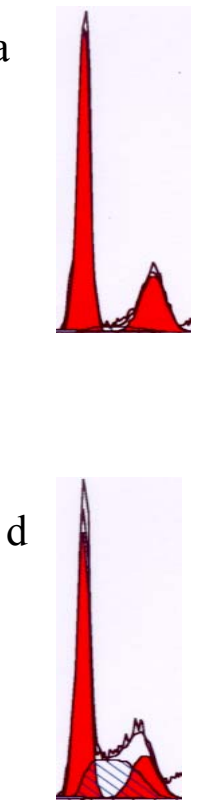

b
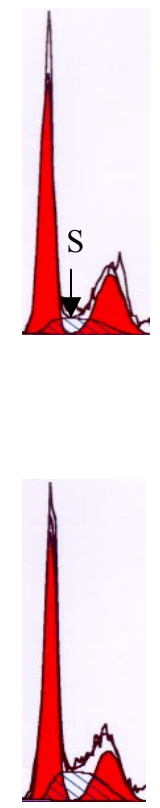

c

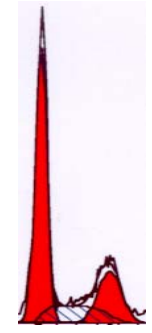

Figure 2 Time dependence of vanadate-induced cell growth arrest in C141 cells. C141 cells were suspended in 5\% fetal bovine serum (FBS) MEM in a $100 \mathrm{~mm}$ dish. After $80 \%$ confluence, cells were washed with PBS three times, and treated with $50 \mu \mathrm{M}$ vanadate for various times. a, control; b, 6 h; c, 12 h; d, 24 $\mathrm{h}$; and e, $48 \mathrm{~h}$. Cells were harvested and DNA content was measured by flow cytometry. Data are from a single preparation representative of three independent experiments. 
a

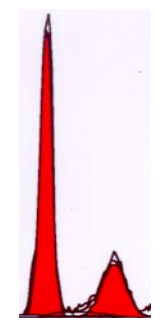

$\mathrm{d}$

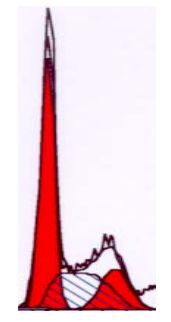

b

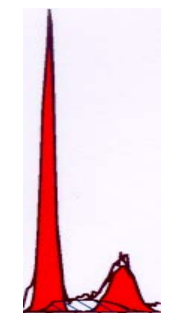

e

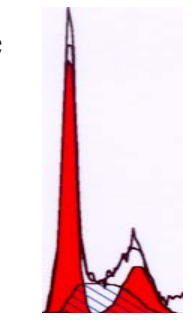

$\mathrm{c}$

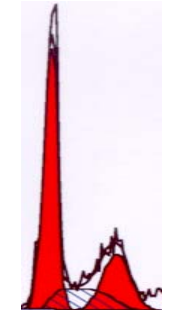

Figure 3 Concentration dependence of vanadate-induced cell growth arrest in C141 cells. These cells were suspended in 5\% fetal bovine serum (FBS) MEM in a $100 \mathrm{~mm}$ dish. After $80 \%$ confluence, cells were washed with PBS three times, and treated with vanadate at various concentration for $24 \mathrm{~h}$. a, control; b, $10 \mu \mathrm{M}$; c, $25 \mu \mathrm{M}$; d, $50 \mu \mathrm{M}$, and e, $100 \mu \mathrm{M}$. Cells were harvested and DNA content was measured by flow cytometry. Data are from a single preparation representative of three independent experiments. 


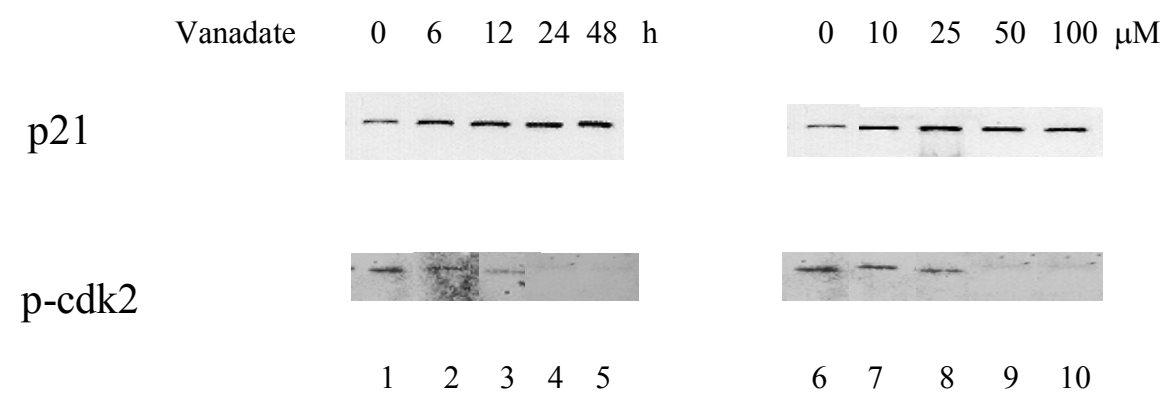

Figure 4 Effects of vanadate on growth regulatory proteins in C141 cells. The cells were treated with $50 \mu \mathrm{M}$ vanadate for $6,12,24$ and $48 \mathrm{~h}$ and 10, 25, 50, $100 \mu \mathrm{M}$ for $24 \mathrm{~h}$. The whole cell lysates were collected for Western blotting using specific antibodies against p-cdk2 and p21. Lanes 1 and 6, control; lanes 2, $50 \mu \mathrm{M} 6 \mathrm{~h}$; lane 3, $50 \mu \mathrm{M}, 12 \mathrm{~h}$; lanes 4 and 9, $50 \mu \mathrm{M}, 24 \mathrm{~h}$; lane 5, $50 \mu \mathrm{M}, 48 \mathrm{~h}$; lane 7, $10 \mu \mathrm{M}, 24 \mathrm{~h}$; lane $8,25 \mu \mathrm{M}, 24 \mathrm{~h}$; and lane 10, $100 \mu \mathrm{M}, 24 \mathrm{~h}$. Data are from a single preparation representative of three independent experiments. 


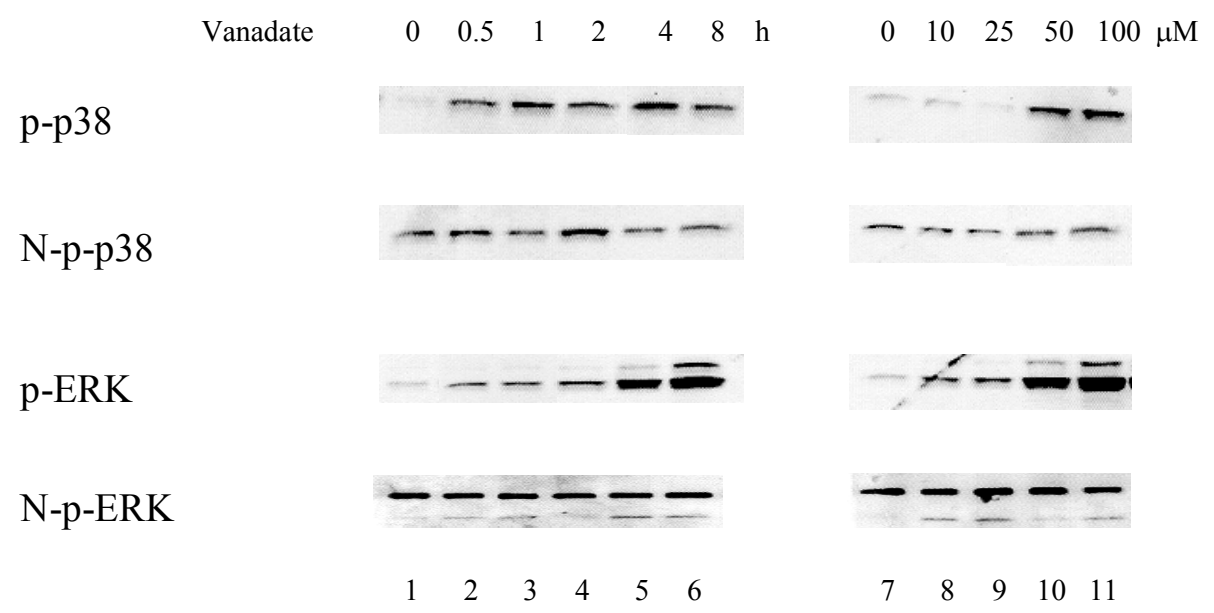

Figure 5 Activation of $\mathrm{p} 38$ and ERK by vanadate in C141 cells. C141 cells were seeded in 6-well plate. Western blotting was performed as described in detail in the Materials and Methods. Lanes 1 and 7, control; lane 2, $50 \mu \mathrm{M}, 0.5$ h; lane 3, 50 $\mu \mathrm{M}, 1 \mathrm{~h}$; lanes $450 \mu \mathrm{M}, 2 \mathrm{~h}$; lanes 5 and 10, $50 \mu \mathrm{M}$, 4h; lane 6, $50 \mu \mathrm{M}, 8 \mathrm{~h}$; lane 8, $10 \mu \mathrm{M}, 4 \mathrm{~h}$; lane 9, $25 \mu \mathrm{M}, 4 \mathrm{~h}$; and lane 11, $100 \mu \mathrm{M}, 4 \mathrm{~h}$. Data are from a single preparation representative of three independent experiments. 
Table 1 Time dependence of vanadate-induced p53 activity ${ }^{1}$

\begin{tabular}{cc}
\hline Incubation time $(\mathrm{h})$ & Relative p53 activity \\
\hline 6 & $1.44 \pm 0.23$ \\
12 & $2.15 \pm 0.19$ \\
24 & $3.71 \pm 0.38^{2}$ \\
48 & $5.33 \pm 0.53^{2}$ \\
\hline
\end{tabular}

1. $1 \times 10^{4}$ cells were seeded into 96 -well plate with $100 \mu 1$ medium each well. The cells were treated with $50 \mu \mathrm{M}$ vanadate for various times. The cells were extracted with lysis buffer. The p53 luciferase activity was measured using a luminomater (Moonlight 3010). The results were expressed as p53 activity relative to control. Each point represents mean \pm SD of three independence experiments.

2. $\mathrm{p}<0.05$ compared to control (one-way ANOVA with Scheffe's test). 
Table 2 Dose-dependence of vanadate-induced p53 activity ${ }^{1}$

\begin{tabular}{cc}
\hline Vanadate concentration $(\mu \mathrm{M})$ & Relative p53 activity \\
\hline 10 & $1.61 \pm 0.28$ \\
25 & $2.64 \pm 0.32^{2}$ \\
50 & $3.71 \pm 0.38^{2}$ \\
100 & $5.44 \pm 0.66^{2}$ \\
\hline
\end{tabular}

1. $1 \times 10^{4}$ cells were seeded into 96 -well plate with $100 \mu$ medium each well. The cells were treated with vanadate at various concentrations for $24 \mathrm{~h}$. The cells were extracted with lysis buffer. The p53 luciferase activity was measured using a luminomater (Moonlight 3010). The results were expressed as p53 activity relative to control. Each point represents mean $\pm \mathrm{SD}$ of three independence experiments.

2. $\mathrm{p}<0.05$ compared to control (one-way ANOVA with Scheffe's test) 


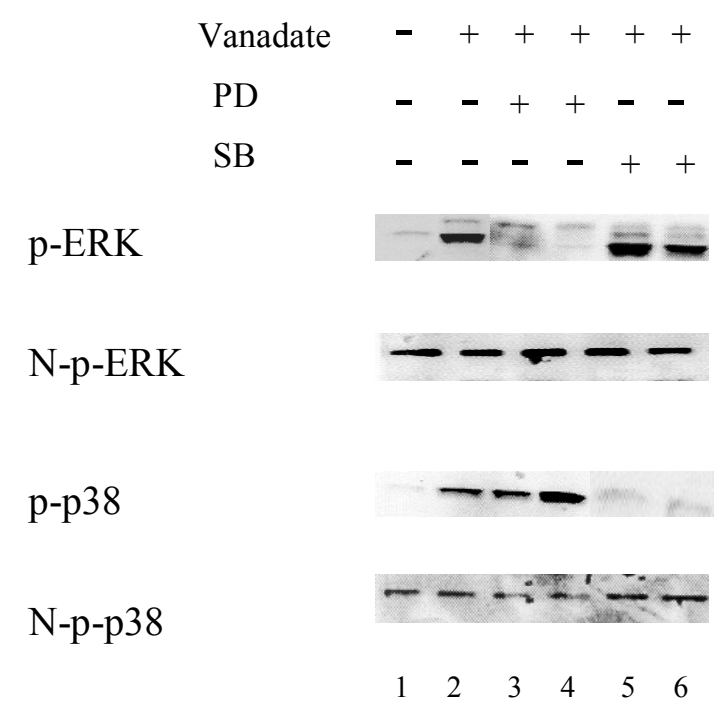

Figure 6 Inhibitory effects of PD98059 and SB202190 on vanadate-activated ERK and p38 in C141 cells. C141 cells were incubated in 6-well plate in MEM medium containing 5\% FBS. The cells were pre-treated with PD or SB for $0.5 \mathrm{~h}$ prior to vanadate treatment $(4 \mathrm{~h})$. The whole cell lysates were used to analyze phospho-p38 and ERK by Western blotting. Lane 1, control without vanadate; lane 2, $50 \mu \mathrm{M}$ vanadate; lane $3,50 \mu \mathrm{M}$ vanadate $+50 \mu \mathrm{M} \mathrm{PD}$; lane 4, $50 \mu \mathrm{M}$ vanadate $+100 \mu \mathrm{M}$ PD; lane $5,50 \mu \mathrm{M}$ vanadate $+10 \mu \mathrm{M} \mathrm{SB}$; and lane 6,50 $\mu \mathrm{M}$ vanadate $+20 \mu \mathrm{M}$ SB. Data are from a single preparation representative of three independent experiments. 
a

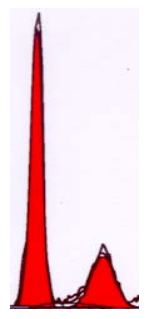

d

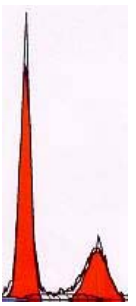

b

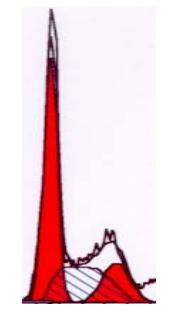

e

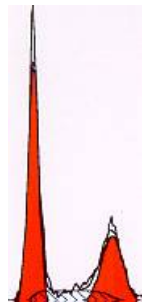

C

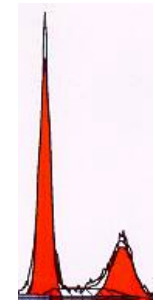

$\mathrm{f}$

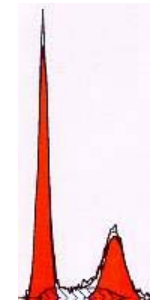

Figure 7 Effects of MAPKs inhibitors on vanadate-induced cell growth arrest in C141 cells. The cells were incubated in a $100 \mathrm{~mm}$ dish and pretreated with PD98059 or SB202190 for $0.5 \mathrm{~h}$ before vanadate treatment $(50 \mu \mathrm{M}, 24 \mathrm{~h})$. After $24 \mathrm{~h}$, cells were harvested, and DNA content was measured by flow cytometry. a, control without vanadate treatment; b, $50 \mu \mathrm{M}$ vanadate; c, $50 \mu \mathrm{M}$ vanadate + $50 \mu \mathrm{M}$ PD; d, $50 \mu \mathrm{M}$ vanadate $+100 \mu \mathrm{M}$ PD; e, $50 \mu \mathrm{M}$ vanadate $+10 \mu \mathrm{M}$ $\mathrm{SB}$; and $\mathrm{f}, 50 \mu \mathrm{M}$ vanadate $+20 \mu \mathrm{M}$ SB. Data are from a single preparation representative of three independent experiments. 


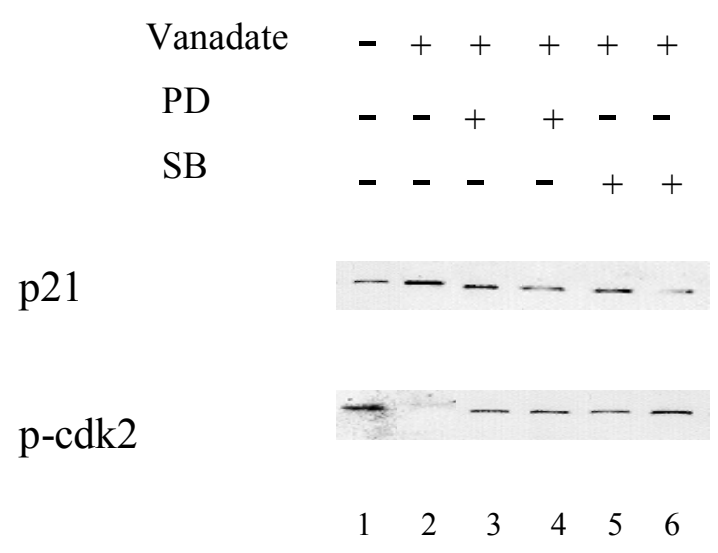

Figure 8 Inhibitory effects of MAPKs inhibitors on vanadate-regulated growth proteins in C141 cells. The cells were incubated in 6-well plate. These cells were pretreated with PD or SB for $0.5 \mathrm{~h}$ before vanadate stimulation $(50 \mu \mathrm{M}, 4 \mathrm{~h})$. The whole cell lysates were collected for Western blotting using specific antibodies against $\mathrm{p}$-cdk2 and $\mathrm{p} 21$. Lane 1, control; lane 2, $50 \mu \mathrm{M}$ vanadate; lane 3, 50 $\mu \mathrm{M}$ vanadate $+50 \mu \mathrm{M} \mathrm{PD}$; lane $4,50 \mu \mathrm{M}$ vanadate $+100 \mu \mathrm{M}$ PD; lane 5, 50 $\mu \mathrm{M}$ vanadate $+10 \mu \mathrm{M} \mathrm{SB}$; and lane $6,50 \mu \mathrm{M}$ vanadate $+20 \mu \mathrm{M} \mathrm{SB}$. Data are from a single preparation representative of three independent experiments. 
Table $3 \quad$ Effects of MAPKs on p53 activity $^{1}$

\begin{tabular}{cl}
\hline MAP kinase inhibitors & Relative p53 activity \\
\hline 0 & $3.71 \pm 0.38$ \\
$50 \mu \mathrm{M} \mathrm{PD}$ & $0.95 \pm 0.17^{2}$ \\
$100 \mu \mathrm{M} \mathrm{PD}$ & $0.42 \pm 0.15^{2}$ \\
$5 \mu \mathrm{M} \mathrm{SB}$ & $0.87 \pm 0.23^{2}$ \\
$10 \mu \mathrm{M} \mathrm{SB}$ & $0.24 \pm 0.06^{2}$ \\
\hline
\end{tabular}

1. $1 \times 10^{4}$ cells were incubated in 96-well plate. The cells were pretreated with PD98059 or SB202190 for $0.5 \mathrm{~h}$ prior to vanadate $(50 \mu \mathrm{M})$ stimulation. After 24 $\mathrm{h}$, the cells were extracted with lysis buffer. The p53 luciferase activity was measured using a luminomater (Moonlight 3010). The results were expressed as p53 activity relative to control. Each point represents mean \pm SD of three independence experiments.

2. $\mathrm{p}<0.05$ compared to vanadate treatment (one-way ANOVA with Scheffe's test). 


\section{IV.7. REFERENCES}

1. Holbrook, N.J. and Fornace A.J., Jr. (1991) Response to adversity: molecular control of gene activation following genotoxic stress. New Biol, 3, 825-33.

2. Holbrook, N.J., Liu Y. and Fornace A.J., Jr. (1996) Signaling events controlling the molecular response to genotoxic stress. Exs, 77, 273-88.

3. Cano, E. and Mahadevan L.C. (1995) Parallel signal processing among mammalian MAPKs. Trends Biochem Sci, 20, 117-22.

4. Karin, M. and Hunter T. (1995) Transcriptional control by protein phosphorylation: signal transmission from the cell surface to the nucleus. Curr Biol, 5, 747-57.

5. Blenis, J. (1993) Signal transduction via the MAP kinases: proceed at your own RSK. Proc Natl Acad Sci U S A, 90, 5889-92.

6. Krady, M.M., Malviya A.N. and Dupont J.L. (1998) Pervanadate-triggered MAP kinase activation and cell proliferation are not sensitive to PD 98059. Evidence for stimulus-dependent differential PD 98059 inhibition mechanism. FEBS Lett, 434, 241-4.

7. Cobb, M.H. and Goldsmith E.J. (1995) How MAP kinases are regulated. J Biol Chem, 270, 14843-6.

8. $\quad$ Seger, R. and Krebs E.G. (1995) The MAPK signaling cascade. FASEB J, 9, 72635.

9. Marshall, C.J. (1995) Specificity of receptor tyrosine kinase signaling: transient versus sustained extracellular signal-regulated kinase activation. Cell, 80, 179-85.

10. Vinals, F. and Pouyssegur J. (1999) Confluence of vascular endothelial cells induces cell cycle exit by inhibiting p42/p44 mitogen-activated protein kinase activity. Mol Cell Biol, 19, 2763-72.

11. Lenormand, P., Sardet C., Pages G., L'Allemain G., Brunet A. and Pouyssegur J. (1993) Growth factors induce nuclear translocation of MAP kinases (p42mapk 
and p44mapk) but not of their activator MAP kinase kinase (p45mapkk) in fibroblasts. J Cell Biol, 122, 1079-88.

12. Gonzalez, F.A., Seth A., Raden D.L., Bowman D.S., Fay F.S. and Davis R.J. (1993) Serum-induced translocation of mitogen-activated protein kinase to the cell surface ruffling membrane and the nucleus. J Cell Biol, 122, 1089-101.

13. Howe, A., Aplin A.E., Alahari S.K. and Juliano R.L. (1998) Integrin signaling and cell growth control. Curr Opin Cell Biol, 10, 220-31.

14. New, L., Jiang Y., Zhao M., Liu K., Zhu W., Flood L.J., Kato Y., Parry G.C. and Han J. (1998) PRAK, a novel protein kinase regulated by the p38 MAP kinase. EMBO J, 17, 3372-84.

15. Zhang, S., Han J., Sells M.A., Chernoff J., Knaus U.G., Ulevitch R.J. and Bokoch G.M. (1995) Rho family GTPases regulate p38 mitogen-activated protein kinase through the downstream mediator Pak1. J Biol Chem, 270, 23934-6.

16. Bagrodia, S., Derijard B., Davis R.J. and Cerione R.A. (1995) Cdc42 and PAKmediated signaling leads to Jun kinase and p38 mitogen- activated protein kinase activation. J Biol Chem, 270, 27995-8.

17. Ono, K. and Han J. (2000) The p38 signal transduction pathway: activation and function. Cell Signal, 12, 1-13.

18. Milne, D.M., Campbell D.G., Caudwell F.B. and Meek D.W. (1994) Phosphorylation of the tumor suppressor protein p53 by mitogen- activated protein kinases. J Biol Chem, 269, 9253-60.

19. Milne, D.M., Campbell L.E., Campbell D.G. and Meek D.W. (1995) p53 is phosphorylated in vitro and in vivo by an ultraviolet radiation- induced protein kinase characteristic of the c-Jun kinase, JNK1. J Biol Chem, 270, 5511-8.

20. Anderson, C.W. (1993) DNA damage and the DNA-activated protein kinase. Trends Biochem Sci, 18, 433-7.

21. Hori, C.a.O., T. (1987) Vanadate enhances the stimulatory action of insurin on DNA synthesis in cultured mouse mammary glands. Biochim Biophys Acta, 610, 235-240. 
22. Nechay, B.R., Nanninga L.B. and Nechay P.S. (1986) Vanadyl (IV) and vanadate (V) binding to selected endogenous phosphate, carboxyl, and amino ligands; calculations of cellular vanadium species distribution. Arch Biochem Biophys, 251, 128-38.

23. Sabbioni, E., Pozzi G., Pintar A., Casella L. and Garattini S. (1991) Cellular retention, cytotoxicity and morphological transformation by vanadium(IV) and vanadium(V) in BALB/3T3 cell lines. Carcinogenesis, 12, 47-52.

24. Carpenter, G. (1981) Vanadate, epidermal growth factor and the stimulation of DNA synthesis. Biochem Biophys Res Commun, 102, 1115-21.

25. Hickey, R.J., Schoff E.P. and Clelland R.C. (1967) Relationship between air pollution and certain chronic disease death rates. Multivariate statistical studies. Arch Environ Health, 15, 728-38.

26. Leonard, A. and Gerber G.B. (1994) Mutagenicity, carcinogenicity and teratogenicity of vanadium compounds. Mutat Res, 317, 81-8.

27. Stock, P. (1965) On the relations between atmospheric pollution in urban and rural location and mortality from cancer, bronchitis, pneumonia, with particular reference to 3,4-benzopyrene, beryllium, molybdenum, vanadium and arsenic. $\mathrm{Br}$ J Cancer, 14, 397-418.

28. Zhong, B.Z., Gu Z.W., Wallace W.E., Whong W.Z. and Ong T. (1994) Genotoxicity of vanadium pentoxide in Chinese hamster V79 cells. Mutat Res, 321, 35-42.

29. Nicoletti, I., Migliorati, G., Pagliacci, M.C., Grignani, F. and Riccardi, C. (1991) A rapid and simple method for measuring thymocyte apoptosis by propidium iodide staining and flow cytometry. J Immunol Methods, 139, 271-279.

30. Sgonic, R.a.W., G (1994.) Methods for the detection of apoptosis. Int Arch Allergy Immunol, 105, 327-332.

31. Smith, J.B. (1983) Vanadium ions stimulate DNA synthesis in Swiss mouse 3T3 and 3 T6 cells. Proc Natl Acad Sci U S A, 80, 6162-6. 
32. Yin, X., Davison A.J. and Tsang S.S. (1992) Vanadate-induced gene expression in mouse C127 cells: roles of oxygen derived active species. Mol Cell Biochem, 115, 85-96.

33. Shi, X., Jiang H., Mao Y., Ye J. and Saffiotti U. (1996) Vanadium(IV)-mediated free radical generation and related 2'- deoxyguanosine hydroxylation and DNA damage. Toxicology, 106, 27-38.

34. Ding, M., Li J.J., Leonard S.S., Ye J.P., Shi X., Colburn N.H., Castranova V. and Vallyathan V. (1999) Vanadate-induced activation of activator protein-1: role of reactive oxygen species. Carcinogenesis, 20, 663-8.

35. Ye, J., Ding M., Zhang X., Rojanasakul Y., Nedospasov S., Vallyathan V., Castranova V. and Shi X. (1999) Induction of TNFalpha in macrophages by vanadate is dependent on activation of transcription factor NF-kappaB and free radical reactions. Mol Cell Biochem, 198, 193-200.

36. Huang, C., Zhang Z., Ding M., Li J., Ye J., Leonard S.S., Shen H.M., Butterworth L., Lu Y., Costa M., Rojanasakul Y., Castranova V., Vallyathan V. and Shi X. (2000) Vanadate induces p53 transactivation through hydrogen peroxide and causes apoptosis. J Biol Chem, 275, 32516-22.

37. Huang, C., Ding M., Li J., Leonard S.S., Rojanasakul Y., Castranova V., Vallyathan V., Ju G. and Shi X. (2001) Vanadium-induced nuclear factor of activated $\mathrm{T}$ cells activation through hydrogen peroxide. $J$ Biol Chem, 276, 22397 403.

38. Ye, J., Ding M., Leonard S.S., Robinson V.A., Millecchia L., Zhang X., Castranova V., Vallyathan V. and Shi X. (1999) Vanadate induces apoptosis in epidermal JB6 P+ cells via hydrogen peroxide-mediated reactions. Mol Cell Biochem, 202, 9-17.

39. Zhang, Z., Huang C., Li J., Leonard S.S., Lanciotti R., Butterworth L. and Shi X. (2001) Vanadate-induced cell growth regulation and the role of reactive oxygen species. Arch Biochem Biophys, 392, 311-20. 
40. Faure, R., Vincent M., Dufour M., Shaver A. and Posner B.I. (1995) Arrest at the G2/M transition of the cell cycle by protein-tyrosine phosphatase inhibition: studies on a neuronal and a glial cell line. J Cell Biochem, 59, 389-401.

41. Chin, L.S., Murray S.F., Harter D.H., Doherty P.F. and Singh S.K. (1999) Sodium vanadate inhibits apoptosis in malignant glioma cells: a role for Akt/PKB. $J$ Biomed Sci, 6, 213-8.

42. Poon, R.Y., Jiang W., Toyoshima H. and Hunter T. (1996) Cyclin-dependent kinases are inactivated by a combination of p21 and Thr-14/Tyr-15 phosphorylation after UV-induced DNA damage. J Biol Chem, 271, 13283-91.

43. Heichman, K.A. and Roberts J.M. (1994) Rules to replicate by. Cell, 79, 557-62.

44. Aprelikova, O., Xiong Y. and Liu E.T. (1995) Both p16 and p21 families of cyclin-dependent kinase (CDK) inhibitors block the phosphorylation of cyclindependent kinases by the CDK- activating kinase. J Biol Chem, 270, 18195-7.

45. Garrington, T.P. and Johnson G.L. (1999) Organization and regulation of mitogen-activated protein kinase signaling pathways. Curr Opin Cell Biol, 11, 211-8.

46. Nebreda, A.R. and Porras A. (2000) p38 MAP kinases: beyond the stress response. Trends Biochem Sci, 25, 257-60.

47. Bitangcol, J.C., Chau A.S., Stadnick E., Lohka M.J., Dicken B. and Shibuya E.K. (1998) Activation of the p42 mitogen-activated protein kinase pathway inhibits Cdc2 activation and entry into M-phase in cycling Xenopus egg extracts. Mol Biol Cell, 9, 451-67.

48. Alblas, J., Slager-Davidov R., Steenbergh P.H., Sussenbach J.S. and van der Burg B. (1998) The role of MAP kinase in TPA-mediated cell cycle arrest of human breast cancer cells. Oncogene, 16, 131-9.

49. Tong, T., Fan W., Zhao H., Jin S., Fan F., Blanck P., Alomo I., Rajasekaran B., Liu Y., Holbrook N.J. and Zhan Q. (2001) Involvement of the MAP kinase pathways in induction of GADD45 following UV radiation. Exp Cell Res, 269, 64-72. 
50. Mansour, S.J., Matten W.T., Hermann A.S., Candia J.M., Rong S., Fukasawa K., Vande Woude G.F. and Ahn N.G. (1994) Transformation of mammalian cells by constitutively active MAP kinase kinase. Science, 265, 966-70.

51. Kortylewski, M., Heinrich P.C., Kauffmann M.E., Bohm M., MacKiewicz A. and Behrmann I. (2001) Mitogen-activated protein kinases control p27/Kip1 expression and growth of human melanoma cells. Biochem J, 357, 297-303.

52. Ziegler-Heitbrock, H.W., Blumenstein M., Kafferlein E., Kieper D., Petersmann I., Endres S., Flegel W.A., Northoff H., Riethmuller G. and Haas J.G. (1992) In vitro desensitization to lipopolysaccharide suppresses tumour necrosis factor, interleukin-1 and interleukin-6 gene expression in a similar fashion. Immunology, 75, 264-8.

53. Takenaka, K., Moriguchi T. and Nishida E. (1998) Activation of the protein kinase p38 in the spindle assembly checkpoint and mitotic arrest. Science, 280, 599-602.

54. Molnar, A., Theodoras A.M., Zon L.I. and Kyriakis J.M. (1997) Cdc42Hs, but not Rac1, inhibits serum-stimulated cell cycle progression at G1/S through a mechanism requiring p38/ERK. J Biol Chem, 272, 13229-35.

55. Shiozaki, K. and Russell P. (1995) Cell-cycle control linked to extracellular environment by MAP kinase pathway in fission yeast. Nature, 378, 739-43.

56. Bulavin, D.V., Higashimoto Y., Popoff I.J., Gaarde W.A., Basrur V., Potapova O., Appella E. and Fornace A.J., Jr. (2001) Initiation of a G2/M checkpoint after ultraviolet radiation requires p38 kinase. Nature, 411, 102-7.

57. Taylor, W.R. and Stark G.R. (2001) Regulation of the G2/M transition by p53. Oncogene, 20, 1803-15.

58. Chan, T.A., Hwang P.M., Hermeking H., Kinzler K.W. and Vogelstein B. (2000) Cooperative effects of genes controlling the $\mathrm{G}(2) / \mathrm{M}$ checkpoint. Genes Dev, 14, 1584-8. 
59. Sablina, A.A., Chumakov P.M., Levine A.J. and Kopnin B.P. (2001) p53 activation in response to microtubule disruption is mediated by integrin-Erk signaling. Oncogene, 20, 899-909.

60. Huang, C., Ma W.Y., Maxiner A., Sun Y. and Dong Z. (1999) p38 kinase mediates UV-induced phosphorylation of p53 protein at serine 389. J Biol Chem, 274, 12229-35. 


\section{SECTION V}

Involvement of E2F1-pRb in Vanadate-induced S Phase Arrest through

Akt Pathway 


\section{V.1. ABSTRACT}

Protein kinase $\mathrm{B}(\mathrm{PKB}) / \mathrm{Akt}$ and its upstream signal transducer, phosphatidylinosito-3 kinase (PI3K) play an essential role in control of transcription and translation, which impact on cell growth, survival and metabolism. Transcription factor $\mathrm{E} 2 \mathrm{~F}$ is a component of the downstream proliferative machinery regulated by Akt. Hyperphosphorylation of retinoblastoma protein $(\mathrm{pRb})$, a pocket protein, leads to release of $\mathrm{E} 2 \mathrm{~F} 1$, resulting in transition of $\mathrm{G}_{1}$ to $\mathrm{S}$ phase. The present study shows that in normal C141 cells, vanadate treatment increased the percentage of cells at $\mathrm{S}$ phase and elevated cyclin $\mathrm{E}$ and cyclin A expression. Vanadate treatment triggered phosphorylation of $\mathrm{pRb}$ and release of E2F1. Furthermore, vanadate increased Akt kinase activity and caused phosphorylation at Ser473 and Thr308. Inhibition of Akt by either inhibitors or transfected cells with dominant negative kinase mutant or dominant negative phosphorylation mutant decreased the percentage of the cells at the S phase induced by vanadate, and reduced both cyclin E and E2F1 expression and phosphorylation of pRb.

The present study indicates that Akt plays an essential role in vanadate-induced S phase arrest and transition from $\mathrm{G}_{1}$ to $\mathrm{S}$ phase through $\mathrm{E} 2 \mathrm{~F}-\mathrm{pRb}$ pathway. 


\section{V.2. INTRODUCTION}

Mammalian cells require an extracellular proliferative signal directly after mitosis in order to keep on growing and dividing. When cells are faced with a lack of such signal, they will either die or go into growth arrest in a postmitotic $G_{1}$ phase. One of the important intracellular signaling pathways that transduce such proliferative signals is phosphatidylinositol-3 kinase (PI3K) pathway (1). The proto-oncogene protein kinase (PKB), known as Akt, is a major target of PI3K signaling in the control of cell proliferation, as it is involved in anti-apoptotic signaling as well as cell cycle control (2). $\mathrm{PKB} / \mathrm{Akt}$ is the cellular homologue of the transforming viral oncogene v-Akt and bears significant homology to PKA and PKC (3). The three mammalian isoforms, $\alpha, \beta$ and $\gamma$, all contain an N-terminal PH domain, a central kinase domain with an activation-loop Thr308 phosphorylation site, and a conserved, regulatory serine phosphorylation site, Ser473 near the $\mathrm{C}$ terminus (4). The full activation of Akt kinase requires the phosphorylation at these two sites (4).

Although the mechanisms by which PKB contributes to the regulation of apoptosis have become better defined, relatively little is known concerning its role in the regulation of cell cycle progression (2). A recent study has demonstrated that the cellcycle regulator $\mathrm{E} 2 \mathrm{~F}$ is a component of the downstream proliferative machinery regulated by Akt (5). One of the key events in $G_{1}$ phase is the activation of E2F, which in turn binds to promoters and trans-activates various genes critical for cell cycle progression, such as cyclin E (2). The E2F family of transcription factors are important regulators of the $\mathrm{G}_{1} / \mathrm{S}$ cell cycle transition, because $\mathrm{E} 2 \mathrm{~F}$ can activate expression of the $\mathrm{S}$ phase regulatory genes necessary for initiating DNA replication (6). E2F is a repressor when complexed with a member of the retinoblastoma $(\mathrm{Rb})$ family of pocket proteins $(7,8)$. The continuation of cell proliferation at various stages of the cell cycle involves inactivation of at least one of three members of the $\mathrm{Rb}$ family (1). The $\mathrm{pRb}$ protein is an 
essential component of the $G_{1} / S$ checkpoint (9). pRb is present at relatively constant levels throughout the cell cycle but is hyperphosphorylated by cyclin/cdk complexes and released from E2F 1 at the $\mathrm{G}_{1} / \mathrm{S}$ transition, allowing continuation through the cell cycle (10).

Vanadate is widely found in occupational and environmental systems. Epidemiological studies have shown a correlation between vanadium exposure and the incidence of lung cancer in humans (11-13). Vanadium compounds were reported to modify DNA synthesis and repair $(11,13,14)$, and induce mutations and DNA-protein crosslinks (14-18). Vanadate is able to induce $\mathrm{G}_{2} / \mathrm{M}$ phase arrest through reactive oxygen species (ROS) in A549 cells (19). A recent study from our group also indicated that vanadate caused p53 dependent S phase arrest in mouse epidermal JB6 cells (20). Our study has shown that vanadate induced expression of both hypoxia-inducible factor 1 (HIF-1) and vascular endothelial growth factor (VEGF) is through PI3K/Akt pathway in DU145 human prostate carcinoma cells and ROS play an important role (unpublished observations).

The purposes of the present study are: (a) to investigate the effect of vanadate on cell cycle arrest; (b) to study the involvement of cell cycle regulatory proteins in the vanadate-induced cell cycle arrest; (c) to examine whether vanadate is able to activate Akt; and (d) to explore the effect of Akt in vanadate-induced cell cycle arrest and its regulation. 


\section{V.3. MATERIALS AND METHODS}

Chemicals Sodium metavanadate was from Aldrich (Milwaukee, WI). RNase A and Eagle's minimal essential medium (MEM) were from Sigma (St. Louis, MO). Fetal bovine serum (FBS) was from Gibco BRL (Life Technologies, Gaithersburg, MD). LY294002, wortmanin were from Calbiochem (San Diego, CA). Dominant negative Akt1 cDNA plasmid was from Upstate (Lake Placid, NY). Antibodies against cyclin E, cyclin A and E2F1 were from Santa Cruz Biotechnology (Santa Cruz, CA). Antibodies against phospho-Rb, Akt and second AP linked anti-rabbit IgG, and Akt kinase assay kit were from Cell Signaling (Beverly, MA).

Cell culture The JB6 $\mathrm{P}^{+}$mouse epidermal cell line, C141 cell, and its stable transfection with dominant negative Akt phosphorylation sites mutant (SR $\alpha$-AktT308A/S473A) cells, DN/P cells, and its stable transfection with dominant negative Akt kinase domain mutant (L179M) cells, DN/K cells were cultured in MEM medium containing 5\% FBS, $2 \mathrm{mM}$ L-glutamine and 1,000 U/ml penicillin-streptomycin in an incubator at $5 \% \mathrm{CO}_{2}$ and $37^{\circ} \mathrm{C}$.

Measurement of cell cycle/DNA content DNA content in $\mathrm{G}_{1} / \mathrm{S}, \mathrm{G}_{2} / \mathrm{M}$ phase was measured using flow cytometry $(21,22)$. C141 cells, DN/K cells and DN/P cells were

fixed and permeabilized with 70\% ice-cold ethanol, and incubated with the freshly prepared staining buffer $(0.1 \%$ Triton X-100 in PBS, $200 \mu \mathrm{g} / \mathrm{ml}$ RNase A, and $20 \mu \mathrm{g} / \mathrm{ml}$ PI) for 15 min at room temperature. Cell cycle analysis was performed by flow cytometry with at least 10,000 cells for each sample. The histogram was abstracted and the percentages of cells in the $G_{1} / S$ and $G_{2} / M$ phase were then calculated using ModFit LT software. 
Western blotting analysis The cells were seeded in $100 \mathrm{~mm}$ dishes. Cells were lysed in RIPA buffer $(150 \mathrm{mM} \mathrm{NaCl}, 100 \mathrm{mM}$ Tris $(\mathrm{pH} 8.0), 1 \%$ Triton $\mathrm{X}-100,1 \%$ deoxycholic acid, 0.1\% SDS, $5 \mathrm{mM}$ EDTA and $10 \mathrm{mM} \mathrm{NaF}$ ) supplemented with $1 \mathrm{mM}$ sodium vanadate, $2 \mathrm{mM}$ leupeptin, $2 \mathrm{mM}$ aprotinin, $1 \mathrm{mM}$ phenylmethylsulfonyl fluoride (PMSF), $1 \mathrm{mM} \mathrm{DTT}$, and $2 \mathrm{mM}$ pepstatin A on ice for $30 \mathrm{~min}$. After centrifugation at $14,000 \mathrm{rpm}$ for $5 \mathrm{~min}$, the supernatant was harvested as the protein extract. The protein concentration was determined using Bio-Rad protein assay reagent (Richmond, CA). The protein extracts were run by Tris-Glycine SDS gel electrophoresis, and transferred to PVDF membrane. Western blotting was performed using antibodies against cyclin E, cyclinA, E2F, phospho-Rb, Akt and second anti-rabbit IgG. After reaction with ECF substrate, the signal was detected using a Storm Scanner (Molecular Dynamics, Sunnyvale, CA).

Akt kinase assay Cells were rinsed once with ice-cold PBS and scraped from the plates, and centrifuged at 4,000 rpm for $5 \mathrm{~min}$. The cell pellet was incubated for $10 \mathrm{~min}$ on ice in lysis buffer (150 mM NaCl, $20 \mathrm{mM}$ Tris- $\mathrm{HCl}$ (pH 7.5), 1\% Triton X-100, $1 \mathrm{mM}$ EDTA, $1 \mathrm{mM}$ EGTA, $2.5 \mathrm{mM}$ sodium pyrophosphate, $1 \mathrm{mM} \beta$-Glycerolphosphate, 1 $\mathrm{mM} \mathrm{Na} \mathrm{VO}_{4}, 1 \mu \mathrm{g} / \mathrm{ml}$ leupeptin) supplemented with $1 \mathrm{mM}$ PMSF, and centrifuged at $11,000 \mathrm{rpm}$ for $10 \mathrm{~min}$ to clarify the supernatants. $200 \mu \mathrm{g}$ of protein extracts were incubated with $20 \mu \mathrm{l}$ of resuspended immobilized Akt antibody slurry gentle rocking $3 \mathrm{~h}$ at $4{ }^{\circ} \mathrm{C}$. The pellets were washed twice with lysis buffer and kinase buffer $(25 \mathrm{mM}$ Tris (pH7.5), $5 \mathrm{mM} \beta$-Glycerolphosphate, $2 \mathrm{mM}$ DTT, $0.1 \mathrm{mM} \mathrm{Na} \mathrm{VO}_{4}, 10 \mathrm{mM} \mathrm{MgCl}$ ), respectively. Then the pellets were suspended in $40 \mu \mathrm{l}$ kinase buffer supplemented with $200 \mu \mathrm{M}$ ATP and $1 \mu \mathrm{g}$ GSK-3 fusion protein, and were incubated $30 \mathrm{~min}$ at $30^{\circ} \mathrm{C} .20 \mu \mathrm{l}$ $3 \times$ SDS sample buffer $\left(187.5 \mathrm{mM}\right.$ Tris- $\mathrm{HCl}\left(\mathrm{pH} 6.8\right.$ at $\left.25^{\circ} \mathrm{C}\right), 6 \% \mathrm{SDS}, 30 \%$ glycerol, $150 \mathrm{mM}$ DTT, $0.03 \%$ bromphenol blue) was added to terminate the reaction, followed by spinning at $11,000 \mathrm{rpm}$ for $2 \mathrm{~min}$. The supernatant was transferred to new tube and boiled for $5 \mathrm{~min}$. Western blotting was performed to probe phospho-GSK- $3 \alpha / \beta$ antibody. 


\section{V.4. RESULTS}

Effects of vanadate on cell cycle in C141 cells DNA content was used to analyze the percentage of the cells at S phase. Figure 1, panel A shows that in C141 cells $50 \mu \mathrm{M}$ vanadate causes a time-dependent increase in S phase from 0 to $24 \mathrm{~h}$. The percentage of the cells at S phase was $7.60 \%$ at beginning of vanadate stimulation, and it was $34.79 \%$ at $24 \mathrm{~h}$. Similarly, a dose-dependency was observed from 0 to $50 \mu \mathrm{M}$ vanadate treatment (panel B). The peaks of S phase appeared at $50 \mu \mathrm{M}$ vanadate treatment for $24 \mathrm{~h}$.

Effects of the vanadate on cell growth regulatory proteins in C141 cells To study the effects of vanadate on cell growth regulatory proteins, Western blotting was used to the expression of cyclin E, cyclin A, and E2F1, and phoshpo-Rb in C141 cells. Figure 2 shows that vanadate caused a time- and dose-dependent increase in cyclin E, cyclinA, and E2F1 level, and phosphorylation of Rb.

Effects of vanadate on Akt in C141 cells Both the kinase assay and Western blotting were used to examine the effects of vanadate on both Akt kinase activity and its phosphorylation in the present study. As shown in Figure 3, $50 \mu \mathrm{M}$ vanadate caused a time-dependent increase of Akt activity (phospho-GSK-3 $\alpha / \beta$ ) (panel A). Similarly, Akt activity was increased with the increase in dose (panel A, lanes 7 to 11). In addition, both the phosphorylations at Ser473 and Thr308 were activated in vanadate-treated cells (panel B). Phosphorylation of Akt was increased with the vanadate treatment time (0 to $240 \mathrm{~min}$ at $50 \mu \mathrm{M})$. Similar results were obtained when the cells were treated with different doses of vanadate (from 0 to $100 \mu \mathrm{M}$ for $120 \mathrm{~min}$ ).

Effects of Akt on cell cycle arrest As shown in Figure 4, panel A, the two PI3K inhibitors, LY294002 and wortmanin, significantly inhibited vanadate-induced S phase arrest in C141 cells. The higher the dose of inhibitors, the less the percentage of cells at S 
phase. In DN/K cells, although vanadate caused increase in S phase in a time- and dosedependent manner, the fold of increase was significantly reduced (panels B-C). The percentage of S phase is $3.75 \%$ in untreated cells and the highest is $8.27 \%$ in cells treated with $50 \mu \mathrm{M}$ vanadate for $48 \mathrm{~h}$ (panel B). The Similar effect was also observed in panel C as the cells were treated with different doses. In the DN/P cells, it is 2.7-fold of increase in $\mathrm{S}$ phase when cells were treated with $50 \mu \mathrm{M}$ vanadate for $24 \mathrm{~h}$ compared to the control cells without stimulation (panel D). In the panel E, the percentage of cells at S phase is $4.38 \%, 5.58 \%, 8.13 \%, 11.61 \%$, and $13.42 \%$ when the cells were stimulated with vanadate at $0,10 \mu \mathrm{M}, 25 \mu \mathrm{M}, 50 \mu \mathrm{M}$, and $100 \mu \mathrm{M}$ for $24 \mathrm{~h}$, respectively. The fold of S phase arrest in DN/P cells is between that in wild type cells and in DN/K cells.

Effects of Akt on cell growth regulatory proteins Both LY294002 and wortmanin reduced vanadate-induced cyclin E, cyclin A, and E2F1 expression, and the phosphorylation of $\mathrm{Rb}$ in $\mathrm{C} 141$ cells (Figure 5, panel A, lanes 3-6). Both kinase mutant and phosphorylation mutant partially reduced vanadate-induced cyclin $\mathrm{E}$ expression (Figure 5, panels B and C). Cyclin E level increased by vanadate treatment in DN/P cells is between that in C141 wild type cells (Figure 2) and DN/K cells (Figure 5, panel B and C). In both $\mathrm{DN} / \mathrm{K}$ and $\mathrm{DN} / \mathrm{P}$ cells, cyclin A level had no observable change compared to the C141 wild type cells (Figure 2). In DN/K cells, both E2F1 expression and phosphorylation of $\mathrm{pRb}$ were at the same low levels regardless vanadate treatment. While E2F1 expression and phosphorylation of pRb slightly increased in DN/P cells treated with vanadate compared to those in wild type cells (Figure 2), they remained in very low levels.

Effects of PI3K on Akt activity PI3K is an upstream kinase of Akt. In this section, we examined the effect of PI3K on Akt activity. As shown in Figure 6, wortmanin and LY294002 completely blocked Akt activity in vanadate-treated C141 cells (panel A, lanes 3-6). Vanadate had no effect on Akt activity in DN/K cells regardless the treatment times and doses (panel B, lanes 1-11). Akt activity was slightly increased in DN/P cells treated 
with vanadate (panel $\mathrm{B}$, lanes 1-11), although the level of increase was much reduced compared to that in wild type cells (Figure 3, panel A).

Effectsof PI3K on Akt phosphorylation Both LY294002 and wortmanin completely blocked the phosphorylation of Akt at Ser473 (Figure 7, panel A). LY294002 did not have any observable inhibitory effect on the phosphorylation of Akt at Thr308 (lanes 3 and 4). In DN/K cells, vanadate-induced phosphorylation at Ser473 and Thr308 (Panels B and C, left part) was much lower than that in wild type cells (Figure 3). In DN/P cells, vanadate failed to activate phosphorylation of Akt at these two major sites (panel B and C, right part). 


\section{V.5. DISCUSSION}

Vanadate compound is widespread in the both environmental and biological systems. It exerts potent toxic and carcinogenic activity. It has been reported that vanadium can regulate growth-factor-mediated signal transduction pathways, promote cell transformation $(23,24)$. Workers occupationally exposed to vanadium are at risk as respirable particulates may penetrate deep into pulmonary tract. Epidemiological studies have shown a correction between vanadium exposure and lung cancer in humans $(15,17)$.

Characterization of cell cycle regulation is important for understanding how extracellular stimuli affect on cell proliferation. Previous studies have shown that vanadate is able to induce S phase arrest in C141 (20). This S phase arrest is p53dependent through activation of p21 and mitogen-activated protein kinase (MAPK) signal transduction pathway (20). The present study shows that vanadate treatment caused increase in the percentage of cells at $\mathrm{S}$ phase in a dose- and time-dependent manner. Cyclin E/cdk2 complex plays a crucial role in the $\mathrm{G}_{1} / \mathrm{S}$ phase transition (25). The expression and activity of cyclin $\mathrm{E}$ follows that of cyclin $\mathrm{D}$, with increase in cyclin $\mathrm{E}$ expression occurring in the nuclus in early $G_{1}$, peaking at the $G_{1} / S$ border, and declining thereafter $(26,27)$. In contrast, cyclin $A$ activity is thought to contribute to the $G_{1} / S$ transition, $\mathrm{S}$ phase progression and $\mathrm{G}_{2} / \mathrm{M}$ transition (25). The present study shows that vanadate treatment is able to cause increase in cylin $\mathrm{E}$ and cyclin A expression in a doseand time-dependent manner.

$\mathrm{PKB} /$ Akt is activated via a multistep process by a variety of signals. In the early steps of this process, PI3K-generated D3-phosphorylated phosphoinositides bind to the Akt PH domain and induce the translocation of the kinase to the plasma membrane where it co-localizes with phosphoinositide-dependent kinase-1. D3-phosphorylated phosphoinositides also appear to induce conformational changes that permit phosphoinositide-dependent kinase-1 to phosphorylate the activation loop of Akt (28). 
Signals induced by stress as well as by beta-adrenergic receptor agonists such as isoproterenol and cAMP have been shown to activate Akt in a PI3K independent manner (29-31). However, it has been reported that the activation of Akt by stress such as hydrogen peroxide, a key member of ROS, or heat stock was PI3K dependent (32). UV induced phosphorylation of Akt at Ser473 and Thr308 in C141 cells was through hydrogen peroxide (33). Vanadate was able to generate ROS, which were involved in vanadate-induced $\mathrm{G}_{2} / \mathrm{M}$ phase arrest (19). Recent study from our group also shows that vanadate induced HIF-1 and VEGF expression was through ROS and PI3K/Akt pathway (unpublished observations). The present study shows that vanadate stimulation not only increased Akt kinase activity, but also caused phosphorylation of Akt at Ser473 and Thr308 in a dose- and time-dependent manner. Addition of two PI3K inhibitors, LY294002 and wortmanin, reduced vanadate-induced Akt kinase activity and its phosphorylation. These results indicate that vanadate-induced Akt activation was PI3K dependent. Moreover, the Akt activity induced by vanadate was blocked in the cells transfected with dominant negative Akt kinase mutant plasmid. In addition, vanadate failed to phosphorylate Akt at Thr308 because activation loop of Thr308 is located in the kinase domain, and mutation at kinase domain affects the function of phosphorylation. However, the phosphorylation at Ser473 was also affected in this type of cells. There are two models of Akt activation. a) Akt is cytosolic, and moves to the plasma membrane in response to PI3K induction (34,35). Ser473 phosphorylation occurs at the membrane. This region forms a docking site for protein dependent kinase-1 (PDK1), which binds and phosphorylates Thr308 (36). b) cytosolic Akt and PDK1 are colocalized, but Akt is inactive due to constraints imposed by its $\mathrm{PH}$ domain (37). Growth factors stimulate PI3K, which draws both PDK1 and Akt to the plasma membrane. The PH domain of Akt binds to phosphatidylinositol-3,4,5-trisphosphate $\left(\operatorname{Ptd} \operatorname{Ins}(3,4,5) \mathrm{P}_{3}\right)$, unmasking the activation loop and allowing PDK1 to phosphorylate Thr308 (37). Subsequent elevation of Akt activity promotes autophosphorylation of Ser473 or phosphorylation by a thirdparty of enzyme, PDK2 (38). Akt is fully activated (39). This is likely that vanadateactivated Akt is through the later model. Akt kinase domain mutation affects its 
phosphorylation at Thr308, which in turn affects phosphorylation at Ser473. Similarly, transfection with dominant negative mutant SR $\alpha$-Akt-T308A/S473A made the cells being unable to be phosphorylated by vanadate. Again the induction of Akt activity by vanadate in this type of cell is less potent than that in wild type cell. That is because Thr308 is located in kinase domain, and mutation of Thr308 affects the kinase activity.

The mammalian cell cycle is a highly regulated process that is influenced by both positive and negative growth-regulatory signals during the $G_{1}$ stage (40). These signals act by controlling the transcriptional activity of a cellular transcription factor E2F. Activation of E2F is sufficient to irreversibly commit cells to undergo DNA replication. Thus E2F is crucial in the control of cellular proliferation in both normal and tumor cells (41). The E2F family determines whether or not a cell will divide by controlling the expression of key cell-cycle regulators. These encoded cell cycle regulators include cyclin E, cyclin A, cdc2, cdc25A, pRb, and E2F1 (6). The E2F family is divided into two distinct groups: E2Fs (E2F1-6) and the DPs (DP1 and DP2) (41). E2F1 is believed to act as a tumor suppressor through its ability to induced apoptosis and cell cycle regulation. It participates in the repression of E2F-responsive genes through recruitment of $\mathrm{pRb}(42)$. However, recent studies indicate that E2F1 might also be involved in the DNA-damageresponse pathway (43). Other studies showed that E2F1 is phosphorylated by the DNAdamage-response kinase, ataxia-telangiectasia mutated (ATM) and ataxia-telangiectasia and Rad3-related (ATR), leading to its stabilization. In the present study, vanadate treatment caused phosphorylation of $\mathrm{pRb}$, which in turn caused itself being inactivated, leading to release of E2F1 (44). Activated E2F therefore triggers the regulation of cyclin E, cyclin A.

It has been shown that dominant negative PI3K and pharmacological inhibitors of PI3K completely abrogate IL-2 induced E2F (5). Furthermore, expression of gag-PKB also induced a strong transcriptional activation of E2F, suggesting that these proliferation effects are indeed mediated via PKB. Another study has shown that activated PI3K 
induced cyclin D1 transcription and E2F activity, at least in part mediated by Akt, suggesting that the PI3K/Akt pathway contributed to the G1 cell cycle progression (45). In addition, it has been reported that Ras-induced increase in E2F1 levels is dependent on Akt in HEK293 cells (46). The present study shows that upon vanadate stimulation, cyclin E/cdk2 complex may trigger the phosphorylation of $\mathrm{pRb}$. The hyperphosphorylated $\mathrm{pRb}$ in turn caused release of $\mathrm{E} 2 \mathrm{~F} 1$, promoting the transition of $\mathrm{G}_{1}$ to S phase. Addition of either LY294002 or wortamnin reduced the expression of cyclin $\mathrm{E}$ and cyclin $\mathrm{A}$, and decreased phosphorylation of $\mathrm{pRb}$ induced by vanadate, resulting in being unable to release E2F1. In addition, cyclin level in DN/P cells was higher than that in $\mathrm{DN} / \mathrm{K}$ cells, but lower than that in wild type cells. However, the mutation of kinase domain or phosphorylation sites seemed to have no effect on cyclin A level. Inhibition of kinase activity by transfection of the cells with dominant negative kinase mutant made vanadate being unable to phosphorylate $\mathrm{pRb}$. In contrast, inhibition of phosphorylation could not completely block phosphorylation of $\mathrm{pRb}$ or E2F1 expression induced by vanadate. This result is consistent with the expression of cyclin E. It is likely that other Akt phosphorylation sites beyond Ser473 and Thr308 can regulate cyclin E. Due to the decreased cyclin E level after inhibition of either kinase activity or phosphorylation, the percentage of cells at $\mathrm{S}$ phase induced by vanadate decreased in both $\mathrm{DN} / \mathrm{K}$ cells and DN/P cells compared to the wild type cells. Moreover, in the control cells without stimulation, transfection with either dominant negative Akt mutant plasmid or dominant negative T308A/S473A mutant plasmid decreased the $\mathrm{S}$ phase arrest compared to the wild type cells. These observations indicate that both transition of $G_{1} / S$ phase and $S$ phase progression are mediated by Akt.

In summary, (a) Vanadate promoted transition of $\mathrm{G}_{1} / \mathrm{S}$ and arrested the cells at $\mathrm{S}$ phase; (b) Vanadate caused increase in cyclin E and cyclin A expression; (c) Vanadate triggered phosphorylation of $\mathrm{pRb}$ and release of E2F1; (d) Vanadate increased both Akt kinase activity and caused its phosphorylation at Ser473 and Thr308; and (e) The inhibition of Akt decreased the vanadate-induced cell cycle arrest at $\mathrm{S}$ phase, and reduced 
both cyclin $\mathrm{E}$ and E2F1 expression and phosphorylation of $\mathrm{pRb}$. The present study indicated that PI3K/Akt signaling plays an essential role in vanadate-induced $\mathrm{S}$ phase arrest through E2F1-pRb pathway. 


\section{V.6. FIGURES}

A

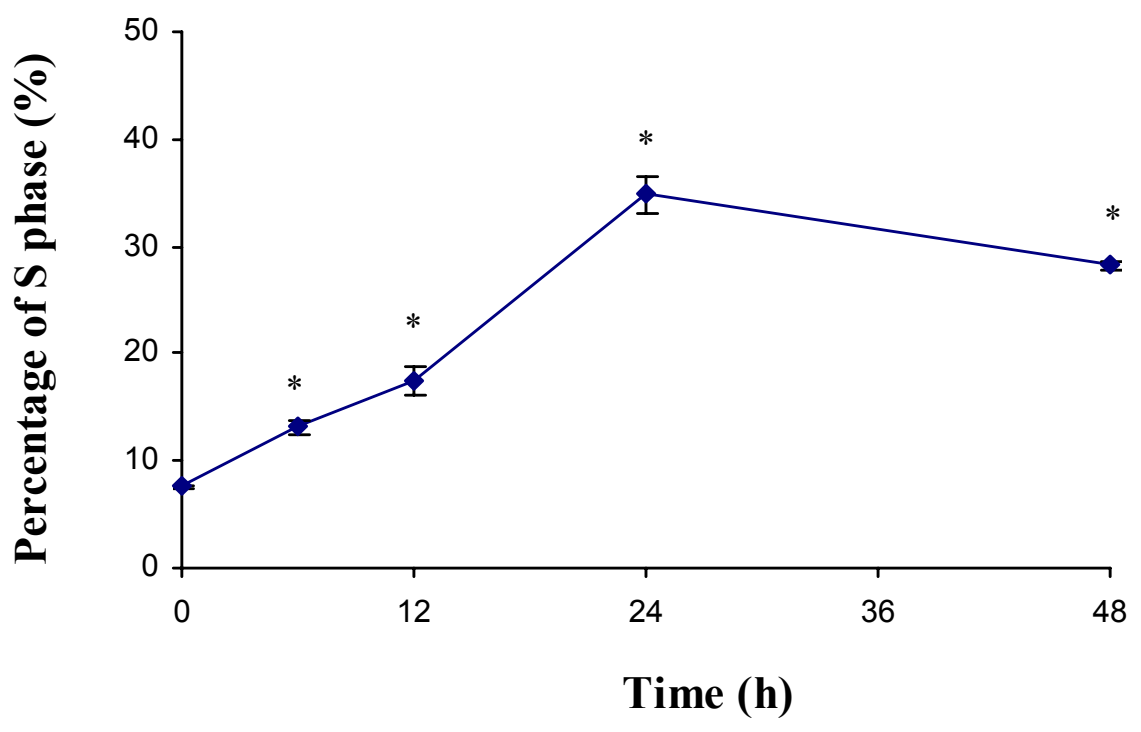

Figure 1 Effects of vanadate on cell cycle arrest at S phase in C141 cells. C141 cells were seeded in 5\% fetal bovine serum (FBS) MEM in a $100 \mathrm{~mm}$ dish. After $80 \%$ confluence, cells were treated with $50 \mu \mathrm{M}$ vanadate for $6,12,24$ and 48 h. DNA content was measured by flow cytometry. Each point represents mean $\pm \mathrm{SD}$ of three independent experiments. *, $\mathrm{p}<0.05$ compare to control (oneway ANOVA with Scheffe's test). 


\section{B}

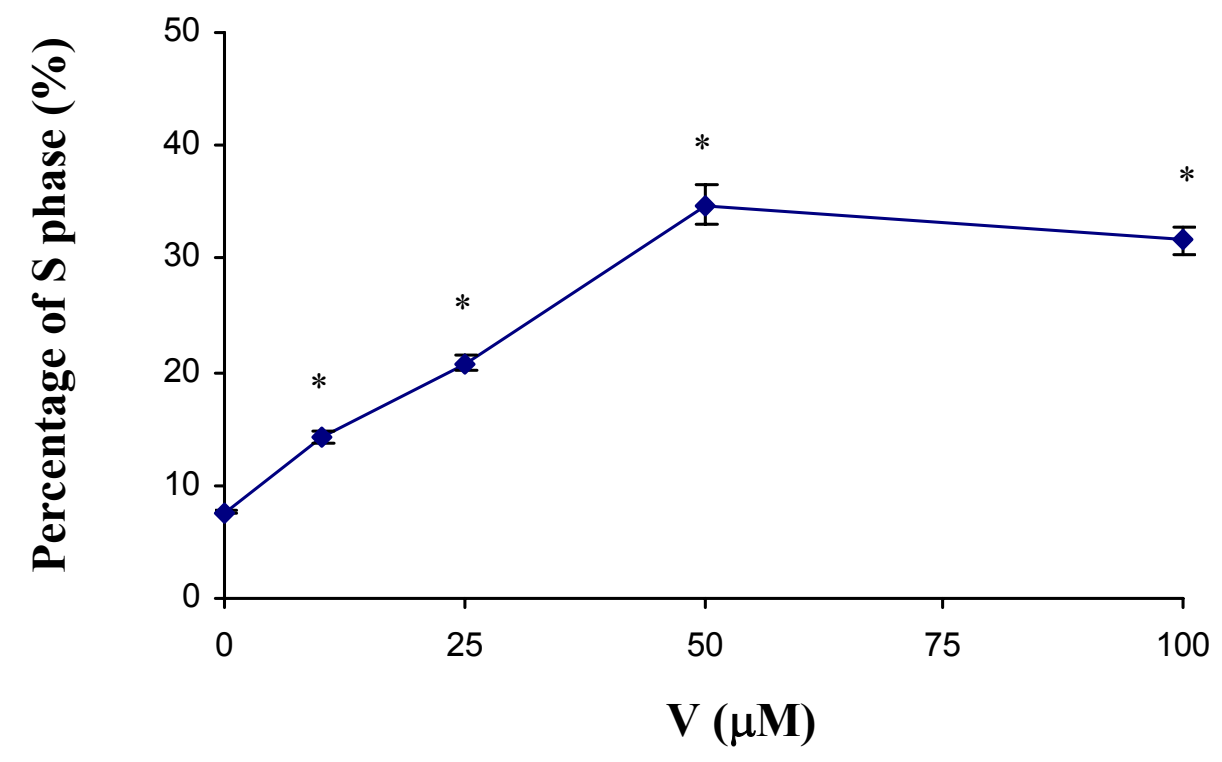

Figure 1 Effects of vanadate on cell cycle arrest at S phase in C141 cells. C141 cells were seeded in 5\% fetal bovine serum (FBS) MEM in a $100 \mathrm{~mm}$ dish. After $80 \%$ confluence, cells were treated with $10,25,50,100 \mu \mathrm{M}$ vanadate for $24 \mathrm{~h}$. DNA content was measured by flow cytometry. Each point represents mean \pm SD of three independent experiments. *, $\mathrm{p}<0.05$ compare to control (one-way ANOVA with Scheffe's test). 


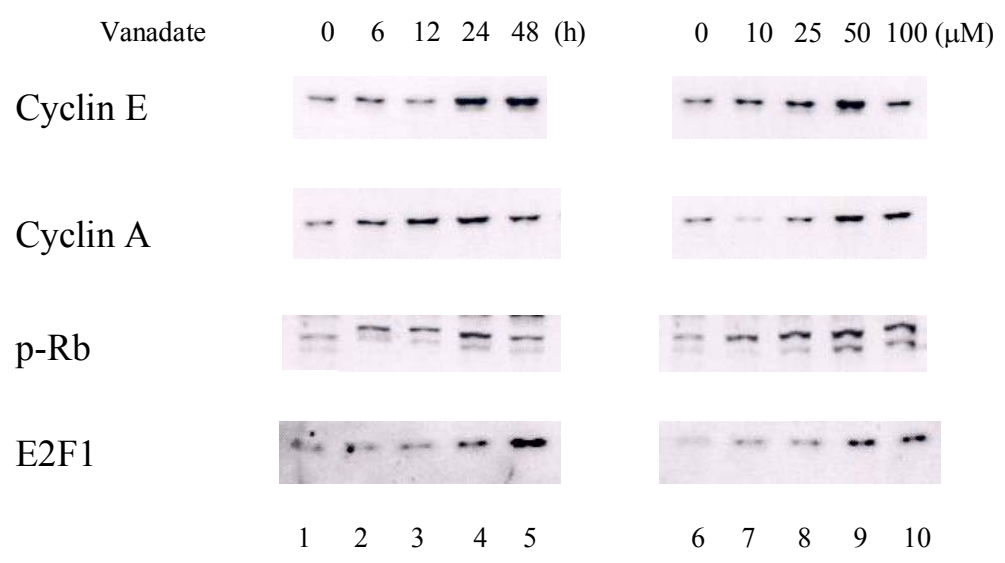

Figure 2 Effects of vanadate on cell growth regulatory proteins in C141 cells. The cells were treated with $50 \mu \mathrm{M}$ vanadate for $6,12,24$ and $48 \mathrm{~h}$ and $10,25,50$, and $100 \mu \mathrm{M}$ for $24 \mathrm{~h}$. The whole cell lysates were collected for Western blotting using specific antibodies against cyclin E, cyclin A, E2F1 and phospho-Rb. Lanes 1 and 6, control; lane 2, $50 \mu \mathrm{M}, 6 \mathrm{~h}$; lane 3, $50 \mu \mathrm{M}, 12 \mathrm{~h}$; lanes 4 and 9, $50 \mu \mathrm{M}, 24 \mathrm{~h}$; lane 5, $50 \mu \mathrm{M}, 48 \mathrm{~h}$; lane 7, $10 \mu \mathrm{M}, 24 \mathrm{~h}$; lane 8, $25 \mu \mathrm{M}, 24 \mathrm{~h}$; and lane 10, $100 \mu \mathrm{M}, 24 \mathrm{~h}$. Data are from a single preparation representative of three independent experiments. 
A

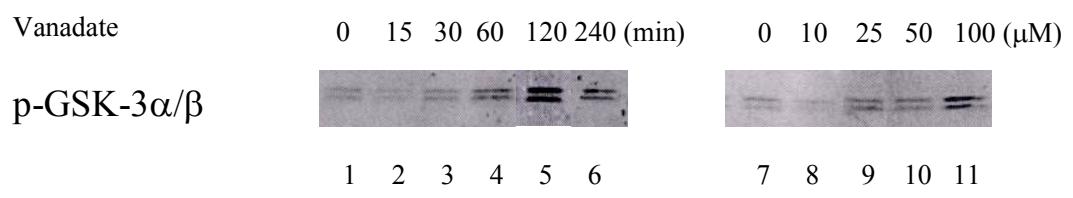

B

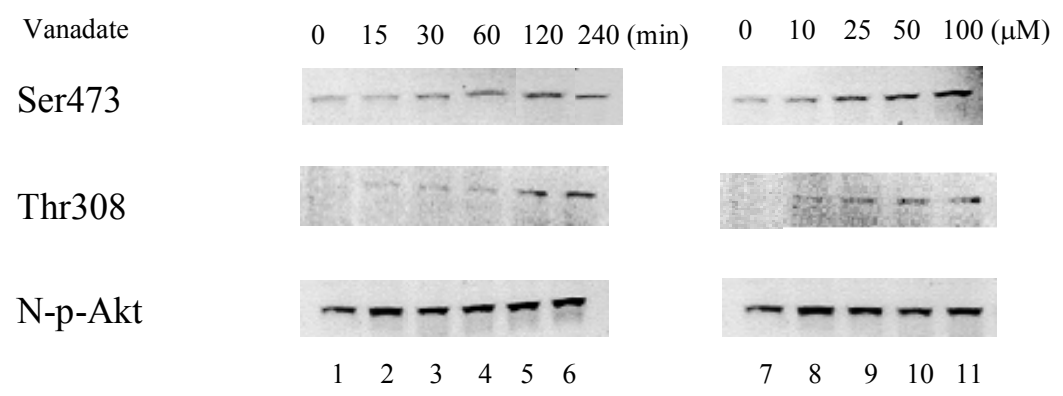

Figure 3 Effects of vanadate on Akt. The cells were treated with $50 \mu \mathrm{M}$ vanadate from 0 to $240 \mathrm{~min}$ and $10,25,50$, and $100 \mu \mathrm{M}$ for $120 \mathrm{~min}$. The whole cell lysates were used to measure the kinase activity and phosphorylation. Panel A and panel B represent Akt kinase activity and phosphorylation of Akt, respectively. Lanes 1 and 7, control; lane 2, $50 \mu \mathrm{M} 15 \mathrm{~min}$; lane 3, $50 \mu \mathrm{M}, 30 \mathrm{~min}$; lanes 4, $50 \mu \mathrm{M}, 60 \mathrm{~min}$; lanes 5 and 10, $50 \mu \mathrm{M}, 120 \mathrm{~min}$; lane 6, $50 \mu \mathrm{M}, 240 \mathrm{~min}$; lane 8, $10 \mu \mathrm{M}, 120 \mathrm{~min}$; lane 9, $25 \mu \mathrm{M}, 120 \mathrm{~min}$; and lane 11, $100 \mu \mathrm{M}, 120 \mathrm{~min}$. Data are from a single preparation representative of three independent experiments. 
A

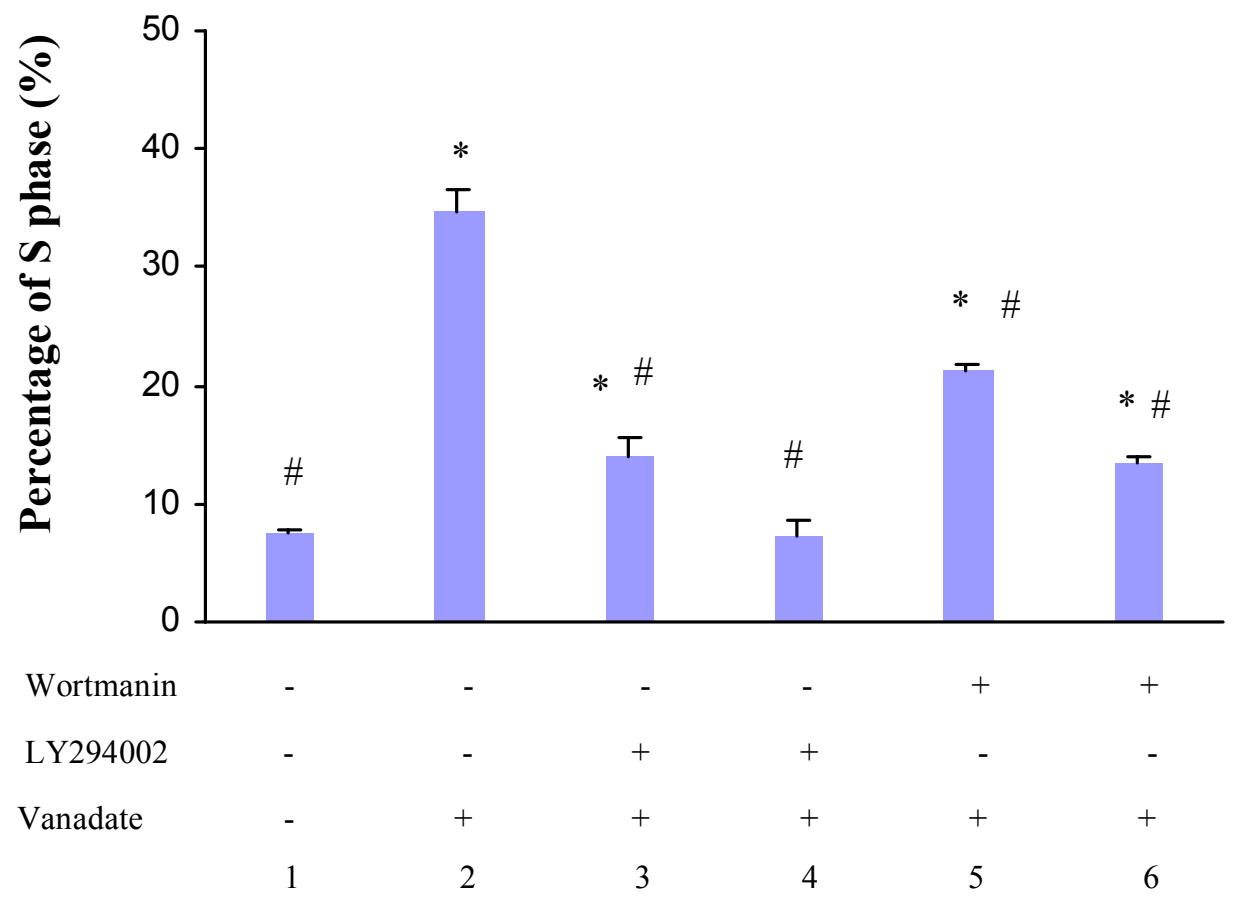

Figure 4 Effects of Akt on cell cycle arrest. The C141 cells were pretreated with different concentrations of LY294002 and wortmanin for $30 \mathrm{~min}$ prior to vanadate treatment $(50 \mu \mathrm{M}$ for $24 \mathrm{~h})$. DNA content was used to measure the percentage of the cells at $\mathrm{S}$ phase. Lane 1, control; lane 2, $50 \mu \mathrm{M}$ vanadate; lane 3, $50 \mu \mathrm{M}$ vanadate $+10 \mu \mathrm{M} \mathrm{LY}$; lane $4,50 \mu \mathrm{M}$ vanadate $+20 \mu \mathrm{M} \mathrm{LY}$; lane $5,50 \mu \mathrm{M}$ vanadate $+50 \mathrm{nM}$ wortmanin; and lane $6,50 \mu \mathrm{M}$ vanadate + $100 \mathrm{nM}$ wortmanin. Each point represents mean $\pm \mathrm{SD}$ of three independent experiments. *, $\mathrm{p}<0.05$ compare to control (one-way ANOVA with Scheffe's test). 


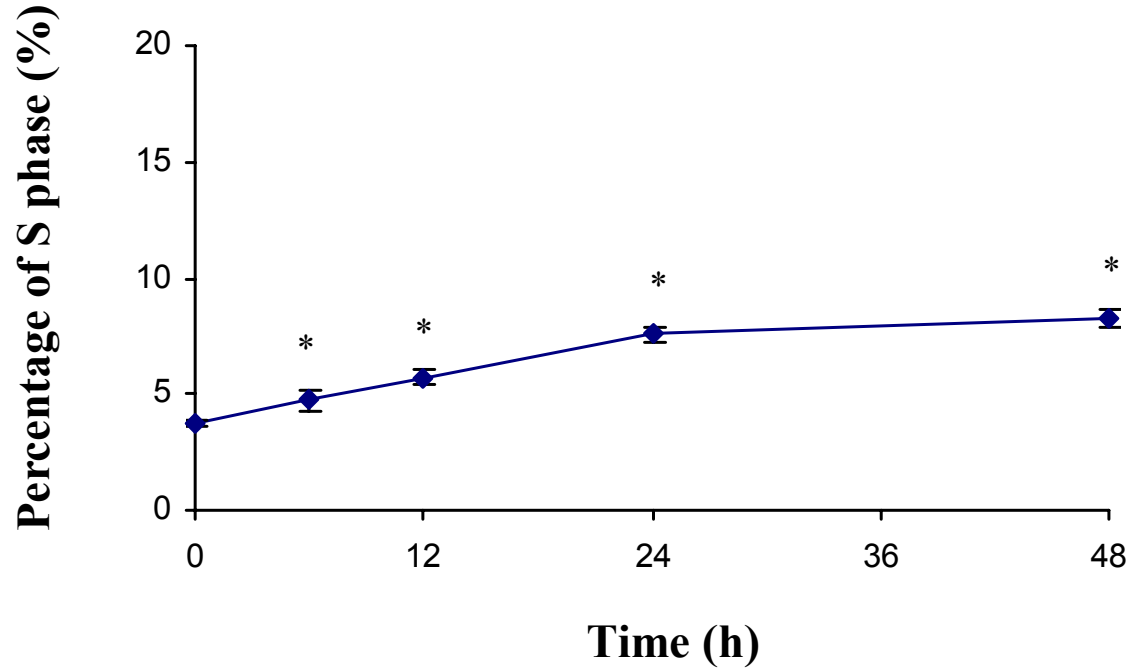

Figure 4 Effects of Akt on cell cycle arrest. DN/K cells were treated with $50 \mu \mathrm{M}$ vanadate for $0,6,12,24$ and $48 \mathrm{~h}$. DNA content was used to measure the percentage of the cells at S phase. Each point represents mean \pm SD of three independent experiments. *, $\mathrm{p}<0.05$ compare to control (one-way ANOVA with Scheffe's test). 


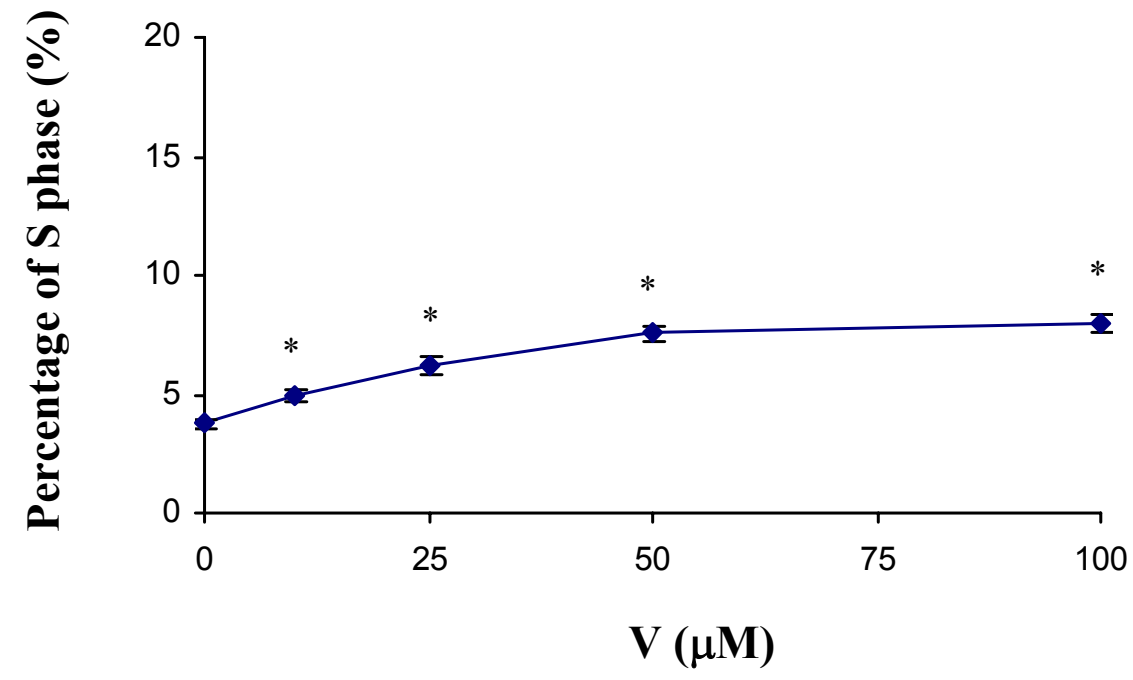

Figure 4 Effects of Akt on cell cycle arrest. DN/K cells were treated with 0, 10, 25, 50, and and $100 \mu \mathrm{M}$ vanadate for $24 \mathrm{~h}$. DNA content was used to measure the percentage of the cells at S phase. Each point represents mean $\pm \mathrm{SD}$ of three independent experiments. *, $\mathrm{p}<0.05$ compare to control (one-way ANOVA with Scheffe's test). 


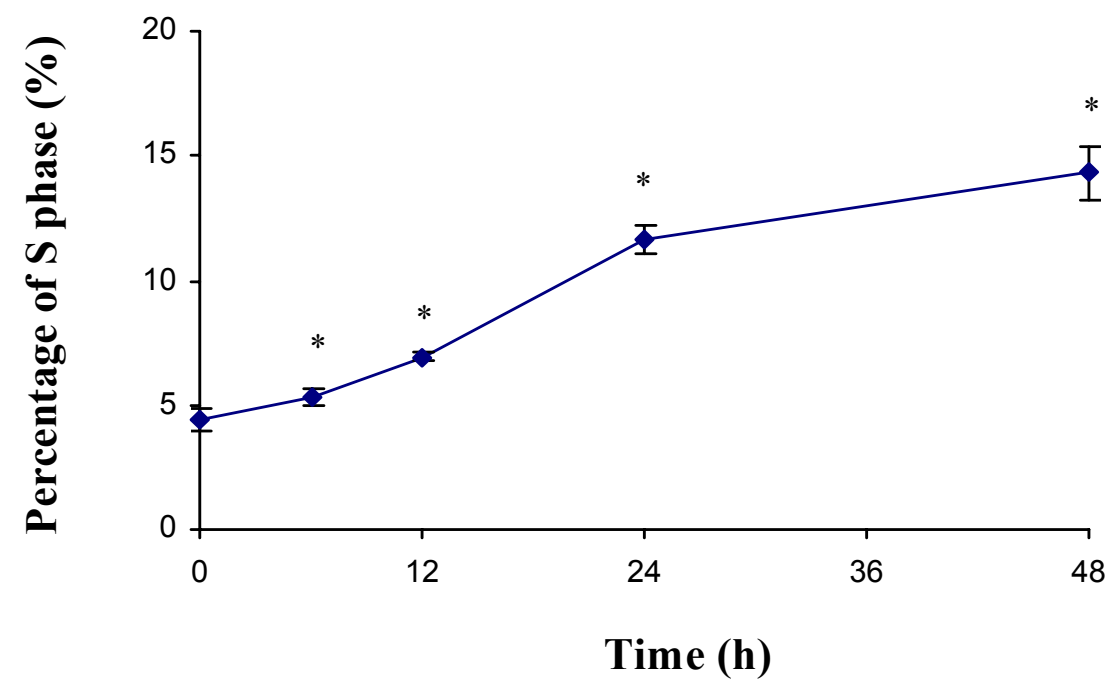

Figure 4 Effects of Akt on cell cycle arrest. DN/P cells were treated with $50 \mu \mathrm{M}$ vanadate for $0,6,12,24$, and $48 \mathrm{~h}$. DNA content was used to measure the percentage of the cells at S phase. Each point represents mean \pm SD of three independent experiments. *, $\mathrm{p}<0.05$ compare to control (one-way ANOVA with Scheffe's test). 


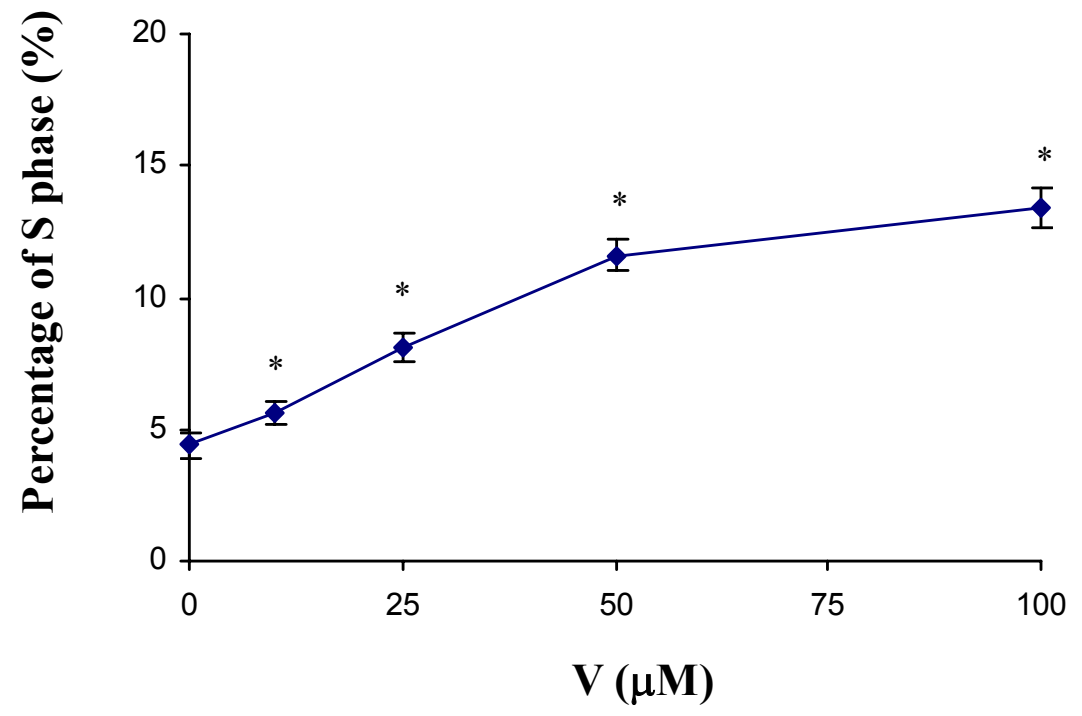

Figure 4 Effects of Akt on cell cycle arrest. DN/P cells were treated with 0, 10, 25, 50, and $100 \mu \mathrm{M}$ vanadate for $24 \mathrm{~h}$. DNA content was used to measure the percentage of the cells at $\mathrm{S}$ phase. The cells Each point represents mean $\pm \mathrm{SD}$ of three independent experiments. *, p $<0.05$ compare to control (one-way ANOVA with Scheffe's test). 


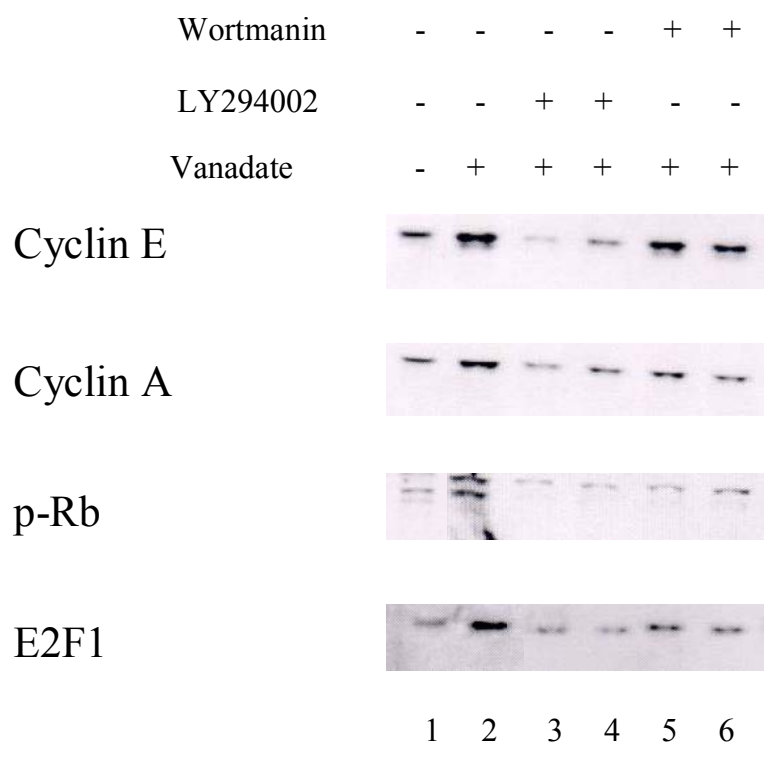

Figure 5 Effects of Akt on cell growth regulatory proteins. The C141 cells were pretreated with different concentrations of LY294002, wortmanin for 30 min before vanadate treatment $(50 \mu \mathrm{M}$ for $24 \mathrm{~h})$. Western blotting was performed to examine the protein levels of cyclin E, cyclin A, E2F1 and phosphorylation of $\mathrm{Rb}$. Lane 1, control; lane 2, vanadate; lane 3, vanadate + $10 \mu \mathrm{M} \mathrm{LY}$; lane 4, vanadate $+20 \mu \mathrm{M}$ LY; lane 5, vanadate $+50 \mathrm{nM}$ wortmanin; and lane 6 , vanadate $+100 \mathrm{nM}$ wortmanin. Data are from a single preparation representative of three independent experiments. 
B

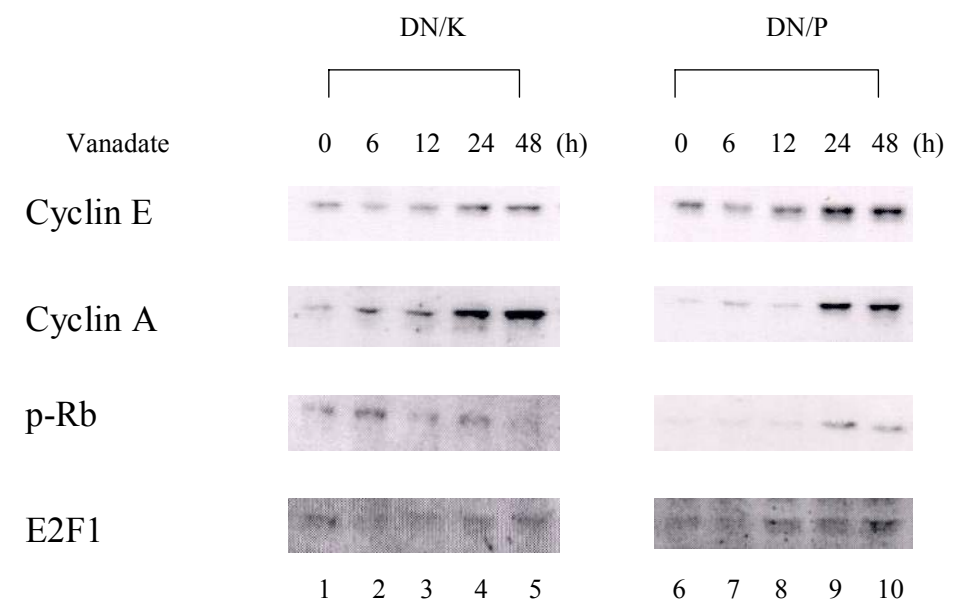

Figure 5 Effects of Akt on cell growth regulatory proteins. The DN/K cells and DN/P cells were treated with $50 \mu \mathrm{M}$ vanadate for different time. Western blotting was performed to examine the protein levels of cyclin E, cyclin A, E2F1 and phosphorylation of $\mathrm{Rb}$. Left part and right part represent $\mathrm{DN} / \mathrm{K}$ cells and $\mathrm{DN} / \mathrm{P}$ cells, respectively. Lanes 1 and 6, control; lanes 2 and 7, $50 \mu \mathrm{M} 6 \mathrm{~h}$; lanes 3 and 8, $50 \mu \mathrm{M}, 12 \mathrm{~h}$; lanes 4 and 9, $50 \mu \mathrm{M}, 24 \mathrm{~h}$; and lanes 5 and 10, $50 \mu \mathrm{M}, 48 \mathrm{~h}$. Data are from a single preparation representative of three independent experiments. 


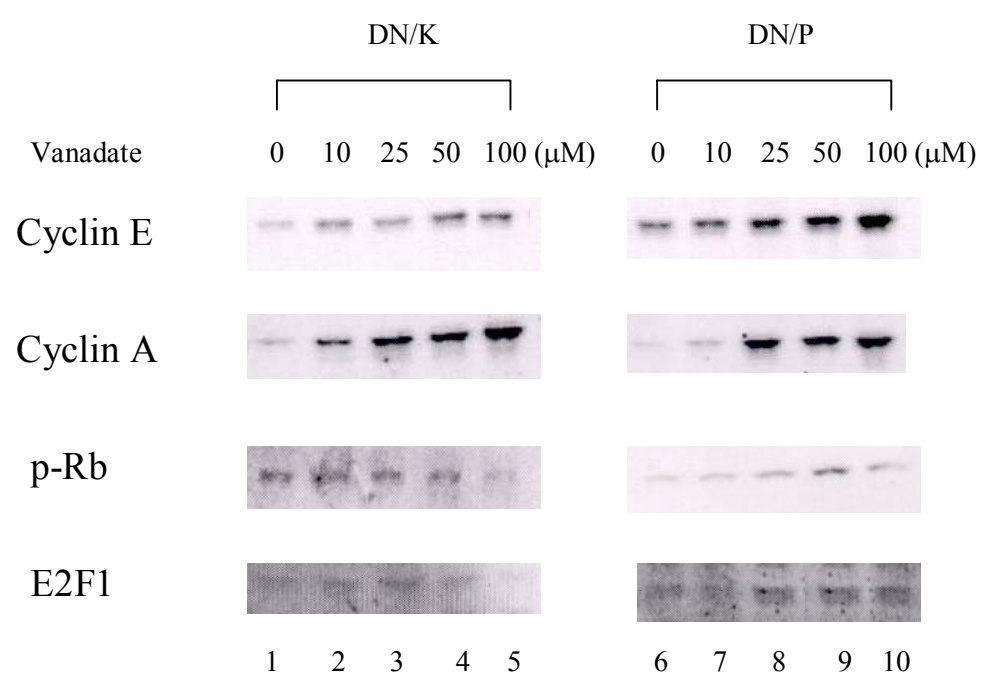

Figure 5 Effects of Akt on cell growth regulatory proteins. The DN/K cells and DN/P cells were treated with different doses of vanadate for $24 \mathrm{~h}$. Western blotting was performed to examine the protein levels of cyclin E, cyclin A, E2F1 and phosphorylation of $\mathrm{Rb}$. Left part and right part represent $\mathrm{DN} / \mathrm{K}$ cells and DN/P cells, respectively. Lanes 1 and 6, control; lanes 2 and 7, $10 \mu \mathrm{M} 24 \mathrm{~h}$; lanes 3 and 8, $25 \mu \mathrm{M}, 24 \mathrm{~h}$; lanes 4 and 9, $50 \mu \mathrm{M}, 24 \mathrm{~h}$; and lanes 5 and 10, $100 \mu \mathrm{M}, 24 \mathrm{~h}$. Data are from a single preparation representative of three independent experiments. 
A

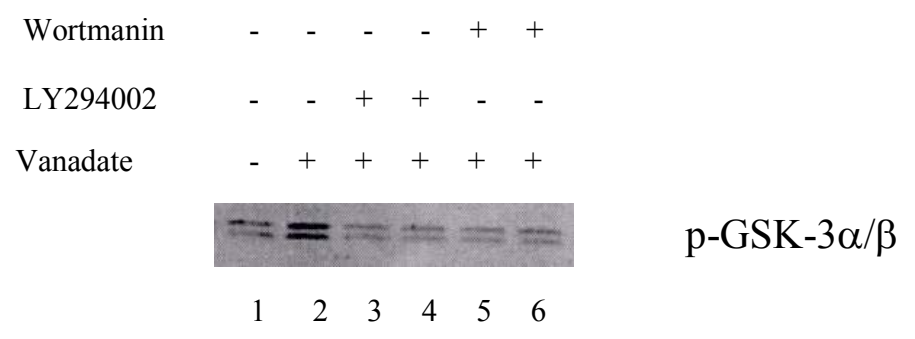

B

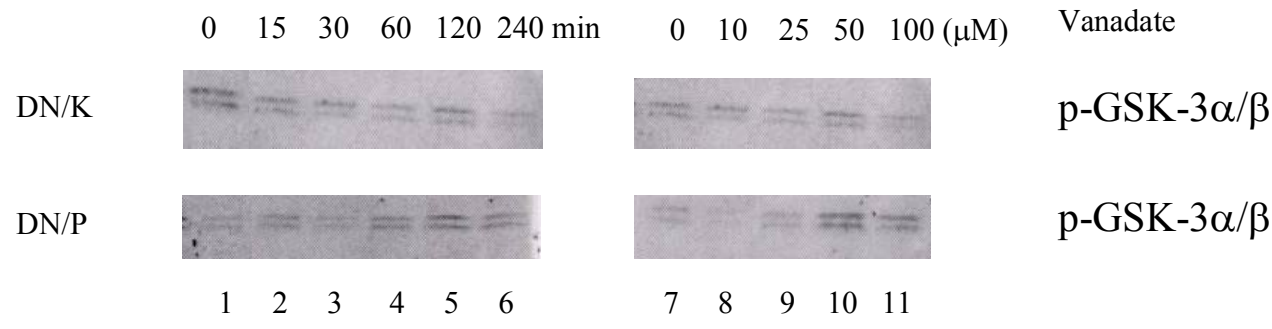

Figure 6 Effects of PI3K on Akt activity. The C141 cells were seeded in $100 \mathrm{~mm}$ dishes. After $80 \%$ confluence, the cells were pre-treated with different concentrations of LY294002, and wortmanin before vanadate treatment $(50 \mu \mathrm{M})$. Panel A: lane 1, control without vanadate stimulation, $60 \mathrm{~min}$; lane 2, vanadate $60 \mathrm{~min}$; lane 3, vanadate $+10 \mu \mathrm{M} \mathrm{LY}, 60 \mathrm{~min}$; lane 4, vanadate $+20 \mu \mathrm{M} \mathrm{LY}, 60 \mathrm{~min}$; lane 5 , vanadate $+50 \mathrm{nM}$ wortmanin, $60 \mathrm{~min}$; and lane 6 , vanadate $+100 \mathrm{nM}$ wortmanin, $60 \mathrm{~min}$. Panel B: lanes 1 and 7, control; lane 2, $50 \mu \mathrm{M} 15 \mathrm{~min}$; lane 3, $50 \mu \mathrm{M}, 30 \mathrm{~min}$; lanes 4, $50 \mu \mathrm{M}, 60 \mathrm{~min}$; lanes 5 and 10, $50 \mu \mathrm{M}, 120 \mathrm{~min}$; lane 6, $50 \mu \mathrm{M}, 240 \mathrm{~min}$; lane 8, $10 \mu \mathrm{M}, 120 \mathrm{~min}$; lane 9, $25 \mu \mathrm{M}, 120 \mathrm{~min}$; and lane $11,100 \mu \mathrm{M}, 120 \mathrm{~min}$. Data are from a single preparation representative of three independent experiments. 
A

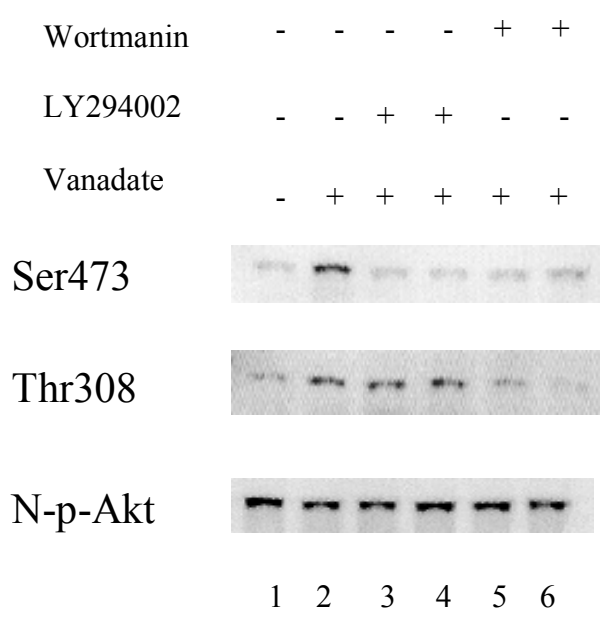

Figure 7 Effects of PI3K on Akt phosphorylation. The C141 cells were spread in 100 $\mathrm{mm}$ dishes. After $80 \%$ confluence, the cells were pre-treated with different concentrations of LY294002, and wortmanin prior to vanadate treatment (50 $\mu \mathrm{M})$. Western blotting was used for measurement of Akt phosphorylation. Lane 1, control without vanadate stimulation, $120 \mathrm{~min}$; lane 2, vanadate 120 min; lane 3, vanadate + $10 \mu \mathrm{M} \mathrm{LY}, 120 \mathrm{~min}$; lane 4, vanadate $+20 \mu \mathrm{M} \mathrm{LY}$, $120 \mathrm{~min}$; lane 5, vanadate $+50 \mathrm{nM}$ wortmanin, $120 \mathrm{~min}$; and lane 6 , vanadate $+100 \mathrm{nM}$ wortmanin, $120 \mathrm{~min}$. Data are from a single preparation representative of three independent experiments. 


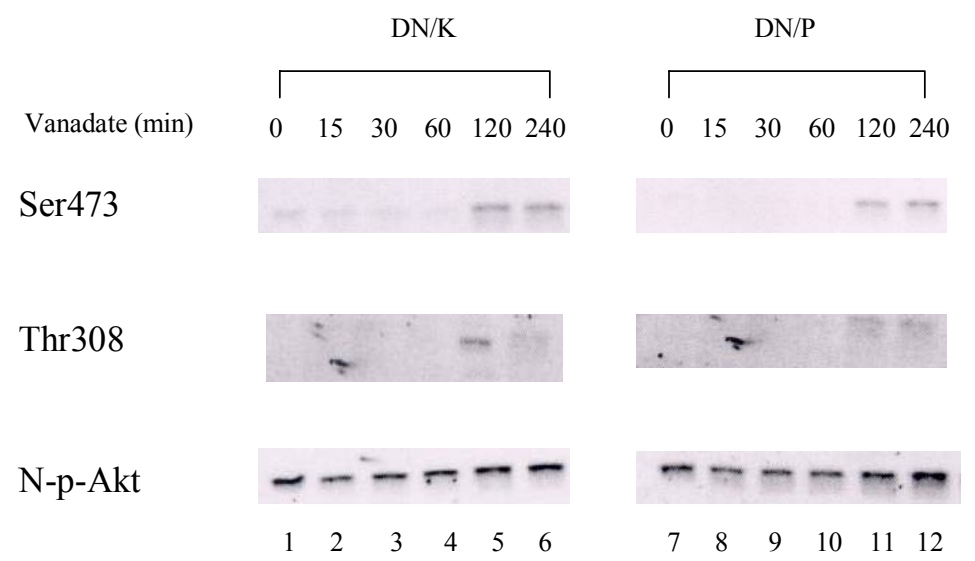

Figure 7 Effects of PI3K on Akt phosphorylation. The DN/K cells and DN/P cells were treated with $50 \mu \mathrm{M}$ vanadate for different time. Western blotting was used for measurement of Akt phosphorylation. Left part and right part represent $\mathrm{DN} / \mathrm{K}$ cells and DN/P cells, respectively. Lanes 1 and 7, control; lanes 2 and 8, $50 \mu \mathrm{M}$ $15 \mathrm{~min}$; lanes 3 and 9, $50 \mu \mathrm{M}, 30 \mathrm{~min}$; lanes 4 and 10, $50 \mu \mathrm{M}, 60 \mathrm{~min}$; lanes 5 and 11, $50 \mu \mathrm{M}, 120 \mathrm{~min}$; and lanes 6 and 12, $50 \mu \mathrm{M}, 240 \mathrm{~min}$. Data are from a single preparation representative of three independent experiments. 
$\mathbf{C}$

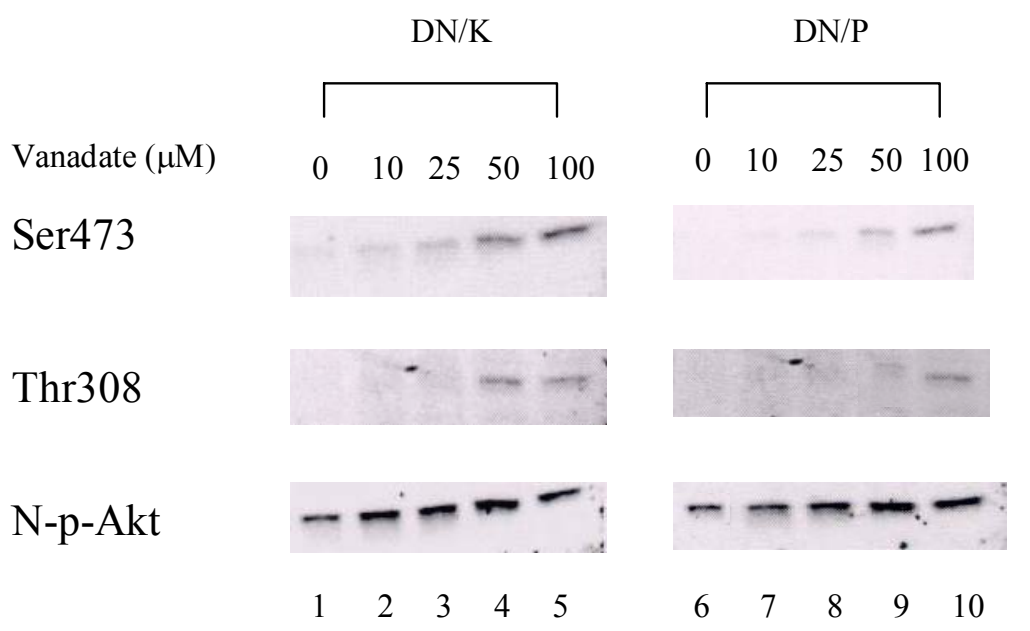

Figure7 Effects of PI3K on Akt phosphorylation. The DN/K cells and DN/P cells were treated with different doses of vanadate for $24 \mathrm{~h}$. Western blotting was used for measurement of Akt phosphorylation. Left part and right part represent DN/K cells and DN/P cells, respectively. Lanes 1 and 6, control; lanes 2 and 7, 10 $\mu \mathrm{M}, 120 \mathrm{~min}$; lanes 3 and 8, $25 \mu \mathrm{M}, 120 \mathrm{~min}$; lanes 4 and 9, $50 \mu \mathrm{M}, 120 \mathrm{~min}$; and lanes 5 and 10, $100 \mu \mathrm{M}, 120 \mathrm{~min}$. Data are from a single preparation representative of three independent experiments. 


\section{V.6. REFERENCES}

1. Kops, G.J., Medema R.H., Glassford J., Essers M.A., Dijkers P.F., Coffer P.J., Lam E.W. and Burgering B.M. (2002) Control of cell cycle exit and entry by protein kinase B-regulated forkhead transcription factors. Mol Cell Biol, 22, $2025-$ 36.

2. Coffer, P.J., Jin J. and Woodgett J.R. (1998) Protein kinase B (c-Akt): a multifunctional mediator of phosphatidylinositol 3-kinase activation. Biochem $\mathrm{J}$, 335, 1-13.

3. Bellacosa, A., Franke T.F., Gonzalez-Portal M.E., Datta K., Taguchi T., Gardner J., Cheng J.Q., Testa J.R. and Tsichlis P.N. (1993) Structure, expression and chromosomal mapping of c-akt: relationship to v-akt and its implications. Oncogene, 8, 745-54.

4. Blume-Jensen, P. and Hunter T. (2001) Oncogenic kinase signalling. Nature, 411, $355-65$.

5. Brennan, P., Babbage J.W., Burgering B.M., Groner B., Reif K. and Cantrell D.A. (1997) Phosphatidylinositol 3-kinase couples the interleukin-2 receptor to the cell cycle regulator E2F. Immunity, 7, 679-89.

6. Dyson, N. (1998) The regulation of E2F by pRB-family proteins. Genes Dev, 12, 2245-62.

7. Weinberg, R.A. (1995) The retinoblastoma protein and cell cycle control. Cell, 81, 323-30.

8. Weintraub, S.J., Prater C.A. and Dean D.C. (1992) Retinoblastoma protein switches the E2F site from positive to negative element. Nature, 358, 259-61.

9. Bosco, G., Du W. and Orr-Weaver T.L. (2001) DNA replication control through interaction of E2F-RB and the origin recognition complex. Nat Cell Biol, 3, 28995.

10. Sherr, C.J. (1996) Cancer cell cycles. Science, 274, 1672-7. 
11. Hori, C.a.O., T. (1987) Vanadate enhances the stimulatory action of insurin on DNA synthesis in cultured mouse mammary glands. Biochim Biophys Acta, 610, 235-240.

12. Nechay, B.R., Nanninga L.B. and Nechay P.S. (1986) Vanadyl (IV) and vanadate (V) binding to selected endogenous phosphate, carboxyl, and amino ligands; calculations of cellular vanadium species distribution. Arch Biochem Biophys, 251, 128-38.

13. Sabbioni, E., Pozzi G., Pintar A., Casella L. and Garattini S. (1991) Cellular retention, cytotoxicity and morphological transformation by vanadium(IV) and vanadium(V) in BALB/3T3 cell lines. Carcinogenesis, 12, 47-52.

14. Carpenter, G. (1981) Vanadate, epidermal growth factor and the stimulation of DNA synthesis. Biochem Biophys Res Commun, 102, 1115-21.

15. Hickey, R.J., Schoff E.P. and Clelland R.C. (1967) Relationship between air pollution and certain chronic disease death rates. Multivariate statistical studies. Arch Environ Health, 15, 728-38.

16. Leonard, A. and Gerber G.B. (1994) Mutagenicity, carcinogenicity and teratogenicity of vanadium compounds. Mutat Res, 317, 81-8.

17. Stock, P. (1965) On the relations between atmospheric pollution in urban and rural location and mortality from cancer, bronchitis, pneumonia, with particular reference to 3,4-benzopyrene, beryllium, molybdenum, vanadium and arsenic. $\mathrm{Br} J$ Cancer, 14, 397-418.

18. Zhong, B.Z., Gu Z.W., Wallace W.E., Whong W.Z. and Ong T. (1994) Genotoxicity of vanadium pentoxide in Chinese hamster V79 cells. Mutat Res, 321, 35-42.

19. Zhang, Z., Huang C., Li J., Leonard S.S., Lanciotti R., Butterworth L. and Shi X. (2001) Vanadate-induced cell growth regulation and the role of reactive oxygen species. Arch Biochem Biophys, 392, 311-20. 
20. Zhang, Z., Huang C., Li J. and Shi X. (2002) Vanadate-induced cell growth arrest is p53-dependent through activation of p21 in C141 cells. J Inorg Biochem, 89, $142-8$.

21. Nicoletti, I., Migliorati, G., Pagliacci, M.C., Grignani, F. and Riccardi, C. (1991) A rapid and simple method for measuring thymocyte apoptosis by propidium iodide staining and flow cytometry. J Immunol Methods, 139, 271-279.

22. Sgonic, R.a.W., G (1994.) Methods for the detection of apoptosis. Int Arch Allergy Immunol, 105, 327-332.

23. Stern, A., Yin X., Tsang S.S., Davison A. and Moon J. (1993) Vanadium as a modulator of cellular regulatory cascades and oncogene expression. Biochem Cell Biol, 71, 103-12.

24. Cruz, T.F., Morgan A. and Min W. (1995) In vitro and in vivo antineoplastic effects of orthovanadate. Mol Cell Biochem, 153, 161-6.

25. Shackelford, R.E., Kaufmann W.K. and Paules R.S. (1999) Cell cycle control, checkpoint mechanisms, and genotoxic stress. Environ Health Perspect, 107 Suppl 1, 5-24.

26. Koff, A., Giordano A., Desai D., Yamashita K., Harper J.W., Elledge S., Nishimoto T., Morgan D.O., Franza B.R. and Roberts J.M. (1992) Formation and activation of a cyclin E-cdk2 complex during the G1 phase of the human cell cycle. Science, 257, 1689-94.

27. Koff, A., Cross F., Fisher A., Schumacher J., Leguellec K., Philippe M. and Roberts J.M. (1991) Human cyclin E, a new cyclin that interacts with two members of the CDC2 gene family. Cell, 66, 1217-28.

28. Chan, T.O., Rittenhouse S.E. and Tsichlis P.N. (1999) AKT/PKB and other D3 phosphoinositide-regulated kinases: kinase activation by phosphoinositidedependent phosphorylation. Annu Rev Biochem, 68, 965-1014.

29. Sable, C.L., Filippa N., Hemmings B. and Van Obberghen E. (1997) cAMP stimulates protein kinase B in a Wortmannin-insensitive manner. FEBS Lett, 409, 253-7. 
30. Konishi, H., Matsuzaki H., Tanaka M., Takemura Y., Kuroda S., Ono Y. and Kikkawa U. (1997) Activation of protein kinase B (Akt/RAC-protein kinase) by cellular stress and its association with heat shock protein Hsp27. FEBS Lett, 410, 493-8.

31. Konishi, H., Matsuzaki H., Tanaka M., Ono Y., Tokunaga C., Kuroda S. and Kikkawa U. (1996) Activation of RAC-protein kinase by heat shock and hyperosmolarity stress through a pathway independent of phosphatidylinositol 3kinase. Proc Natl Acad Sci U S A, 93, 7639-43.

32. Shaw, M., Cohen P. and Alessi D.R. (1998) The activation of protein kinase B by $\mathrm{H} 2 \mathrm{O} 2$ or heat shock is mediated by phosphoinositide 3-kinase and not by mitogenactivated protein kinase- activated protein kinase-2. Biochem J, 336, 241-6.

33. Huang, C., Li J., Ding M., Leonard S.S., Wang L., Castranova V., Vallyathan V. and Shi X. (2001) UV Induces phosphorylation of protein kinase B (Akt) at Ser473 and Thr- 308 in mouse epidermal $\mathrm{Cl} 41$ cells through hydrogen peroxide. $J$ Biol Chem, 276, 40234-40.

34. Franke, T.F., Yang S.I., Chan T.O., Datta K., Kazlauskas A., Morrison D.K., Kaplan D.R. and Tsichlis P.N. (1995) The protein kinase encoded by the Akt proto-oncogene is a target of the PDGF-activated phosphatidylinositol 3-kinase. Cell, 81, 727-36.

35. Franke, T.F., Kaplan D.R., Cantley L.C. and Toker A. (1997) Direct regulation of the Akt proto-oncogene product by phosphatidylinositol-3,4-bisphosphate. Science, 275, 665-8.

36. Persad, S., Attwell S., Gray V., Mawji N., Deng J.T., Leung D., Yan J., Sanghera J., Walsh M.P. and Dedhar S. (2001) Regulation of protein kinase B/Akt-serine 473 phosphorylation by integrin-linked kinase: critical roles for kinase activity and amino acids arginine 211 and serine 343. J Biol Chem, 276, 27462-9.

37. Andjelkovic, M., Alessi D.R., Meier R., Fernandez A., Lamb N.J., Frech M., Cron P., Cohen P., Lucocq J.M. and Hemmings B.A. (1997) Role of translocation in the activation and function of protein kinase B. J Biol Chem, 272, 31515-24. 
38. Toker, A. and Newton A.C. (2000) Akt/protein kinase B is regulated by autophosphorylation at the hypothetical PDK-2 site. J Biol Chem, 275, 8271-4.

39. Scheid, M.P. and Woodgett J.R. (2001) PKB/AKT: functional insights from genetic models. Nat Rev Mol Cell Biol, 2, 760-8.

40. Sherr, C.J. and Roberts J.M. (1999) CDK inhibitors: positive and negative regulators of G1-phase progression. Genes Dev, 13, 1501-12.

41. Trimarchi, J.M. and Lees J.A. (2002) Sibling rivalry in the E2F family. Nat Rev Mol Cell Biol, 3, 11-20.

42. Yamasaki, L., Jacks T., Bronson R., Goillot E., Harlow E. and Dyson N.J. (1996) Tumor induction and tissue atrophy in mice lacking E2F-1. Cell, 85, 537-48.

43. Meng, R.D., Phillips P. and El-Deiry W.S. (1999) p53-independent increase in E2F-1 expression enhances the cytotoxic effects of etoposide and of adriamycin. Int J Oncol, 14, 5-14.

44. Lin, W.C., Lin F.T. and Nevins J.R. (2001) Selective induction of E2F1 in response to DNA damage, mediated by ATM-dependent phosphorylation. Genes Dev, 15, 1833-44.

45. Gille, H. and Downward J. (1999) Multiple ras effector pathways contribute to G(1) cell cycle progression. J Biol Chem, 274, 22033-40.

46. Berkovich, E. and Ginsberg D. (2001) Ras induces elevation of E2F-1 mRNA levels. J Biol Chem, 276, 42851-6. 


\section{SECTION VI}

The Role of Phosphatidylinositol-3 Kinase and p70 S6 Kinase in Vanadate-induced Cell Cycle Arrest at S Phase 


\section{VI.1. ABSTRACT}

Phosphatidylinositil-3 kinase (PI3K) is a heterodimer of catalytic and regulatory subunits. It is involved in various signaling pathways and key functions of the cells. The present study investigated the role of PI3K in vanadate-induced cell cycle arrest in C141 mouse epidermal cells. Vanadate caused a dose-dependent increase in p21 and decrease in both cdc $25 \mathrm{~A}$ and cdk2. In stable transfaction with dominant negative p85 luciferase reporter $\Delta \mathrm{p} 85$ cells, vanadate did not alter these cell cycle regulatory proteins. Vanadate caused a time- and dose-dependent increase in PI3K activity through phosphorylation of p70 S6 kinase (p70S6K) at Thr421/Ser424 and Thr389 sites. The phosphorylation at these sites was inhibited both by PI3K inhibitor, LY294002, and p70S6K mutation. Moreover, vanadate induced S phase arrest was inhibited by LY294002 and rapmycin, a p70S6K inhibitor. Vanadate-induced S phase arrest was also inhibited in transfection with dorminant negeative p70S6K mutant cells. In these cells, vanadate-induced activation of $\mathrm{p} 21$ and the degradation of $\operatorname{cdc} 25 \mathrm{~A}$ and $\operatorname{cdk} 2$ were inhibited. Taken together the results obtained show that vanadate is able to increase PI3K activity through phosphorylation. PI3K activated p70S6K, which phosphated protein S6 and controlled the cell cycle regulatory proteins and blocked vanadate-induced cell cycle arrest at $\mathrm{S}$ phase. 


\section{VI.2. INTRODUCTION}

Epidemiological studies have demonstrated that inhalation of environmental or occupational airborne particle mattes results in an increased incidence of cardiopulmonary disorders and lung cancer (1-4). Yet our understanding about biological mechanisms and the initiation and progression of disease as a result of exposure to particular mattes is still primitive and fragmentary. Most of environmental and occupational particular matters contain various trace metal ions, including vanadium, chromium, arsenite, zinc, and nickel $(5,6)$. It is generally believed that metal ions may contribute to the pathological effects of inhaled particular matters. Among these metal ions, vanadate regulates growth factors mediated by signal transduction, promotes cell transformation, and decreases cell adhesion (7-10). Vanadate-containing compounds exert potent toxic effects on a wide variety of biological systems $(7,11)$. Vanadium compounds were reported to modify DNA synthesis (12), cause direst DNA damage and induce DNA strand breaks (13). Epidemiological studies have shown a correlation between vanadium exposure and the incidence of lung cancer in humans $(14,15)$.

The regulation of cell cycle is frequently altered in human cancer cells (16). Cells initiate apoptosis and cell cycle arrest checkpoints in resonse to DNA-damaging agents, such as $\gamma$ irradiation (17). This is biologically important since the failure of DNAdamaged cells to die or growth arrest allows the accumulation of new mutations and may contribute to tumorigenic development (18). Thus apoptosis and cell growth arrest are biological defense against DNA damage to maintain genomic integrity. Our recent studies have shown that vanadate caused cell cycle arrest at $\mathrm{S}$ phase and mitogenactivated proteins kinses (MAPKs) were involved (19-21). In the present study, we investigated the mechanistic aspect of vanadate-induced cell cycle arrest at S phase with focus on the role of phosphatidylinositol-3 kinase (PI3K). PI3K is a hetrodimer of catalytic and regulatory subunits with molecular weights of $110 \mathrm{KD}(\mathrm{p} 110)$ and $85 \mathrm{KD}$ 
(p85), respectively. It is an enzyme that participates in a variety of cellular processes and whose activity has liked to cell growth and transformation, differentiation, motility, insulin action, and cell survival $(22,23)$. Direct links between PI3K and human diseases have been made, most notably in cancer (23). Recent studies have suggested that the involvement of PI3K in regulating cell division may be through at least two mechanisms: the PI3K lipid kinase activity and direct interaction of PI3K with some cellular signal proteins (22). We hypothesize that vanadate may induce activation of PI3K, which upregulates its downstream, $\mathrm{p} 70 \mathrm{~S} 6 \mathrm{~K}$, affects cell growth regulatory proteins, $\mathrm{p} 21, \operatorname{cdc} 25 \mathrm{~A}$ and cdk2, and induces cell cycle arrest. The present study will test this hypothesis. 


\section{VI.3. MATERIALS AND METHODS}

Chemicals Sodium metavanadate was purchased from Aldrich (Milwaukee, WI). RNase A and Eagle's minimal essential medium (MEM) were from Sigma (St. Louis, MO) were from Sigma (St. Louis, MO). Propidium iodide (PI) was from Molecular Probes (Eugene, OR). Fetal bovine serum (FBS) was from Gibco BRL (Life Technologies, Gaithersburg, MD). LY294002 and rapamycin were from Calbiochem (San Diego, CA). Antibodies to p21 and cdc25A were from Santa Cruz Biotechnology (Santa Cruz, CA). Antibodies to phospho-cdk2 at Thr160, p70S6K and second AP linked anti-rabbit IgG were from Cell Signaling (Beverly, MA).

Cell culture The JB6 $\mathrm{P}^{+}$mouse epidermal cell line, C141 cells, and its stable transfection with dominant negative p85 luciferase reporter cells, $\Delta \mathrm{p} 85$ cells, and its stable transfection with dominant negative mutant p70S6 kinase cells (DN/p70S6K) were cultured in MEM medium containing 5\% FBS, 2 mM L-glutamine and $1000 \mathrm{U} / \mathrm{ml}$ penicillin-streptomycin in an incubator at $5 \% \mathrm{CO}_{2}$ and $37^{\circ} \mathrm{C}$.

Measurement of cell cycle/DNA content DNA content in $\mathrm{G}_{1} / \mathrm{S}, \mathrm{G}_{2} / \mathrm{M}$ phase was detected using flow cytometry $(24,25)$. Both C141 cells and DN/p70S6K cells were fixed and permeabilized with $70 \%$ ice-cold ethanol for more than $2 \mathrm{~h}$, and incubated with the freshly prepared staining buffer $(0.1 \%$ Triton X-100 in PBS, $200 \mu \mathrm{g} / \mathrm{ml}$ RNase A, and 20 $\mu \mathrm{g} / \mathrm{ml} \mathrm{PI}$ ) for $15 \mathrm{~min}$ at $37^{\circ} \mathrm{C}$. Cell cycle analysis was performed by flow cytometry with at least 10,000 cells for each sample. The histogram was abstracted and the percentages of cells in the $G_{1} / S$ and $G_{2} / M$ phase were then calculated using ModFit LT software.

Western blotting analysis The cells were seeded in $100 \mathrm{~mm}$ dishes. Cells were lysed in RIPA buffer $(150 \mathrm{mM} \mathrm{NaCl}, 100 \mathrm{mM}$ Tris $(\mathrm{pH} 8.0), 1 \%$ Triton $\mathrm{X}-100,1 \%$ deoxycholic acid, $0.1 \%$ SDS, $5 \mathrm{mM}$ EDTA and $10 \mathrm{mM} \mathrm{NaF}$ ) supplemented with $1 \mathrm{mM}$ 
sodium vanadate, $2 \mathrm{mM}$ leupeptin, $2 \mathrm{mM}$ aprotinin, $1 \mathrm{mM}$ phenylmethylsulfonyl fluoride (PMSF), $1 \mathrm{mM}$ DTT, and $2 \mathrm{mM}$ pepstatin A on ice for $30 \mathrm{~min}$. After centrifugation at $14,000 \mathrm{rpm}$ for $5 \mathrm{~min}$, the supernatant was harvested as the protein extract. The protein concentration was determined using Bio-Rad protein assay reagent (Richmond, CA). The protein extracts were run by Tris-Glycine SDS gel electrophoresis, and transferred to PVDF membrane. Western blotting was performed using antibodies against $\mathrm{p} 21$, cdc25A, phospho-cdk $2^{\text {Thr160 }}$, p70S6K and second anti-rabbit IgG. After reaction with ECF substrate, the signal was detected using a Storm Scanner (Molecular Dynamics, Sunnyvale, CA).

PI3K activity assay Cells were washed with ice-cold PBS and scraped from the plates, and centrifuged at 4,000 rpm for $5 \mathrm{~min}$. The cell pellet was incubated for $20 \mathrm{~min}$ on ice in lysis buffer $(150 \mathrm{mM} \mathrm{NaCl}, 100 \mathrm{mM}$ Tris-HCl (pH 8.0), 1\% Triton X-100, 5 mM EDTA, $10 \mathrm{mM} \mathrm{NaF)} \mathrm{supplemented} \mathrm{with} 1 \mathrm{mM}$ DTT, $1 \mathrm{mM}$ PMSF, $1 \mathrm{mM}$ sodium vanadate, $2 \mathrm{mM}$ leupeptin, and $2 \mathrm{mM}$ aprotinin, and centrifuged at 11,000 rpm for $15 \mathrm{~min}$ to clarify the supernatants. PI3K activity was analyzed using $400 \mu \mathrm{g}$ of protein extracts and anti-p110 antibodies as described $(28,29)$. Briefly, $400 \mu \mathrm{g}$ of total protein was incubated $20 \mu \mathrm{l}$ of protein $\mathrm{A} / \mathrm{G}$ plus agarose for $1 \mathrm{~h}$ at $4^{\circ} \mathrm{C}$ on a rotator, followed by spinning at 3,000 rpm for $3 \mathrm{~min}$. The supernatant was then incubated with $10 \mu \mathrm{lof}$ p110PI3 kinase antibody for $1 \mathrm{~h}$ at $4^{\circ} \mathrm{C} .30 \mu \mathrm{l}$ of protein $\mathrm{A} / \mathrm{G}$ agarose beads were added for an additional $1 \mathrm{~h}$. The beads were then pelleted and washed sequentially with TNE buffer (containing $20 \mathrm{mM}$ Tris, pH7.5, $100 \mathrm{mM} \mathrm{NaCl}$ and $1 \mathrm{mM}$ EDTA) for five times; and once with $20 \mathrm{mM}$ HEPES. PI3K assays were performed using phosphatidylinositol as substrate in a final volume of $50 \mu$ containing 20 mM HEPES ( $\mathrm{pH} 7.5$ ), $10 \mathrm{mM} \mathrm{MgCl,} 2$ $\mu \mathrm{Ci}\left[\gamma_{-}{ }^{32} \mathrm{P}\right] \mathrm{ATP}, 60 \mu \mathrm{M}$ ATP, and $0.2 \mathrm{mg} / \mathrm{ml}$ sonicated phosphatidylinositol. Reactions were carried out for $15 \mathrm{~min}$ at room temperature and extracted by the addition of $80 \mu \mathrm{l}$ $1 \mathrm{M} \mathrm{HCl}$ and $160 \mu \mathrm{l}$ chloroform/methanol (1:1). After centrifugation, organic phase was 
evaporated to dryness and separated by Thin Layer Chromatographer (TLC). Phosphorylated lipids were identified by autoradiography. 


\section{VI.4. RESULTS}

Effects of the vanadate on $p 21, c d c 25 A$ and phoshpo-cdk $2^{\text {Thr160 }}$ in both C141 cells and $4 p 85$ cells The previous studies showed that vanadate is able to cause cell cycle arrest at $\mathrm{S}$ phase. Here several $\mathrm{S}$ phase regulatory proteins were examined in vanadatestimulated C141 cells. Western blotting was used to measure the expression of both p21 and $\operatorname{cdc} 25 \mathrm{~A}$, and phosphorylation of cdk2 (Figure 1). In C141 cells, vanadate caused expression of p21 and degradation of cdc25A (panel A). Treatment of the cells with 50 $\mu \mathrm{M}$ vanadate for $6 \mathrm{~h}$ decreased phosphorylation of cdk2. At $24 \mathrm{~h}$ and $48 \mathrm{~h}$ treatment, phospho-cdk2 was almost abolished (panel A, lanes 4 and 5). A dose-dependent inactivation of phospho-cdk2 was observed when the cells were treated with different times (panel $\mathrm{A}$, lanes 6 to 10). In contrast, in $\Delta \mathrm{p} 85$ cells vanadate could not alter the expression of $\mathrm{p} 21$ and cdc25A, or phosphorylation of cdk 2 regardless treatment times and doses (panel B).

Effects of vanadate on PI3K activity and cell cycle regulatory proteins in C141 cells In the present study, thin layer chromatographer was used to examine PI3K activity, and Western blotting was performed to measure the cell growth regulatory proteins. As shown in Figure 2, panel A a, in C141 cells treatment with $50 \mu \mathrm{M}$ vanadate increased the signal intensity from 15 min to 240 min compared to the control. A dosedependency was also observed when the C141 cells were treated with different concentrations of vanadate (panel A, b). In panel B, addition of LY294002, an inhibitor of PI3K, decreased p21 expression induced by vanadate, and increased phosphorylation of cdk2 inactivated by vanadate.

\section{Effects of vanadate on p70S6K in both C141 cells and $4 p 85$ cells Western}

blotting was used to detect the phosphorylation of p70S6K in C141 cells, vanadate caused phosphorylation of p70S6K at both Thr421/Ser424 and Thr389 in a time- and dose- 
dependent manner (Figure 3, panel A). In $\Delta$ p85 cells, vanadate treatment failed to cause phosphorylation at these sites (Figure 3, panel B).

Effects of PI3K on vanadate-induced p70S6K phosphorylation $\mathrm{p} 70 \mathrm{~S} 6 \mathrm{~K}$ is a downstream target kinase of PI3K. In the previous two sections, we have shown that vanadate is able to activate both PI3K and p70S6K. In this section, PI3K inhibitor, LY924002, was used to evaluate the role of PI3K in vanadate-induced p70S6K phosphorylation. As shown in Figure 4, the presence of LY294002 completely prevented PI3K activation in vanadate-treated C141 cells (panel A). Such inhibition subsequently affected the downstream protein p70S6K phosphorylation. LY294002 completely inhibited p70S6K phosphorylation at Thr421/Ser424 and Thr389 (panel B). In DN/p70S6K cells, phosphorylation at Thr421/Ser424 and Thr389 sites did not occur regardless vanadate treatment times and doses (panel C).

Effects of PI3K on vanadate-induced cell cycle arrest As shown in Figure 5, panel A, LY294002 inhibited vanadate-induced S phase arrest in C141 cells. Similar effect was also observed in the cells treated with p70S6K inhibitor, rapmycin. Moreover, in the $\mathrm{DN} / \mathrm{p} 70 \mathrm{~S} 6 \mathrm{~K}$ cells, although vanadate treatment caused increase in $\mathrm{S}$ phase, it was much less potent (Panels B and C). For comparison, data of vanadate-induced S phase arrest in wild type C141 cells were provided in Figure 5, panels D and E.

Effects of PI3K on cell growth regulatory proteins in vanadate-treated cells In the previous section, we have shown that vanadate induced an increase in p21 and decreased in cdc25A and phosphated cdk2 through action of PI3K. In this section, we examined the role of p70S6K. In contrast with wild type C141 cells (Figure 1A), vanadate decreased p21 and it did not decrease cdc25A or phosphated cdk2. Instead, in the DN/p70S6K cells, vanadate increased the levels of cdc25A and phosphated cdk2. These results are opposite to those observed using wild type C141 cells, demonstrating the role of p70S6K in vanadate-induced alternation of those cell cycle regulatory proteins. 


\section{VI.5. DISCUSSION}

The ability of cells to maintain genomic integrity is vital for cell survival and proliferation. Cell cycle transitions are controlled by distinct families of cyclin-dependent kinases (cdks). The activity of these kinases is regulated by association with cyclins and cdk inhibitors and by positive and negative phosphorylation (26-28). Following association with cyclins and positive phosphorylation at a specific threonine residue, cdks are maintained in an inactive state by inhibitory phosphorylation at Thr14 and Tyr15 $(22,26)$. The inactive cyclin/cdk complexes are dephosphorylated by cdc25 phophatases, which are regard as important regulators of cell progression (29). Among the three cdc25 isoforms, cdc25A promotes entry of cells into $\mathrm{S}$ phase by dephosphorylating and activating $\mathrm{cdk} 2 /$ cyclin $\mathrm{E}$ and $\mathrm{cdk} 2 /$ cyclinA complexes (30). An inhibitory protein, $\mathrm{p} 21$, exhibits its cell growth inhibiting activity through its interaction with cdk2. In the present study, we have shown that in wild type C141 cells under vanadate stimulation, p21 protein level was increased while cdc $25 \mathrm{~A}$ level and phosphorylation of cdk2 were decreased. Since cdc $25 A$ and $\operatorname{cdk} 2$ promote $G_{1} / S$ phase progression and p21 inhibits it, the results were consistent with our previous report that vanadate was able to cause $\mathrm{S}$ phase arrest (19). The question is how these cell cycle regulatory proteins are regulated. In the present study, we examined the role of PI3K and its downstream target proteins. In C141 cells with dominant negative mutant of the regulatory subunit of PI3K, $\Delta \mathrm{p} 85$ cells, vanadate did not cause any observable change in $\mathrm{p} 21$, cdc25A or cdk 2 . These results demonstrate that PI3K is required for vanadate-induced alteration in these cell cycle regulatory proteins.

Using thin layer chromatographer, we have shown that vanadate increased PI3K activity. One of the important downstream targets of PI3K is p70S6K. The importance of this kinase at a molecular level is that it is involved in the selective translational regulation of a unique family of mRNAs, by mediating the multiple phosphorylation of 
40S ribosomal protein S6 (31). These mRNAs encode for components of the translational apparatus, including ribosomal proteins and translational elongation factors whose increased expression is essential for cell growth and proliferation (32). In the present study, we have measured vanadate-induced phosphorylation of p70S6K at Thr421/Ser424 and Thr389 sites. In $\Delta$ p85 cells, the phosphorylation at these sites was not observed, indicating an important role of PI3K in p70S6K phosphorylation. We have also examined the role of PI3K in vanadate induced p70S6K phosphorylation using PI3K inhibitor, LY294002. This inhibitor decreased vanadate-induced PI3K activation. LY294002 inhibited vanadate-induced phosphorylation of p70S6K at Thr421/Ser424 and Thr389. In DN/p70S6K cells, vanadate failed to phosphorylate p70S6K. The above results indicated that vanadate induced PI3K activation, which then caused p70S6K phosphorylation.

Using flow cytometry to measure DNA content, our results show that vanadate is able to induce cell cycle arrest at $\mathrm{S}$ phase in wild type C141 cell. PI3K inhibitor, LY924002, and p70S6K inhibitor, rapmycin, blocked vanadate-induced cell cycle arrest at $\mathrm{S}$ phase. In $\mathrm{DN} / \mathrm{p} 70 \mathrm{~S} 6 \mathrm{~K}$ cells, vanadate-induced cell cycle arrest at $\mathrm{S}$ phase was inhibited. These results show that PI3K and p70S6K were involved in the mechanism of vanadate-induced cell cycle arrest. The relationship between cell cycle regulatory preotiens and p70S6K was also investigated in the present study. The results showed that in $\mathrm{DN} / \mathrm{p} 70 \mathrm{~S} 6 \mathrm{~K}$ cells, vanadate-induced activation of p21 and degradation of cdc25A and cdk2 were inhibited. These results are consistent with inhibition of vanadate-induced cell cycle arrest at $\mathrm{S}$ phase. Now the question is how PI3K and p70S6K affect the cellular regulatory proteins. Phosphoyrlated S6 kinase increases production of the translational mechanery such as ribosomal proteins and alongation factors. PI3K also appears to play a role in the down-regulation of the cdk inhibitors p27 and p21 (33). p21 may be a direct target of Akt phosphorylation. PI3K and its downstream kinase Akt are signaling intermediates that link cell surface receptors to p70S6K (23). The previous chapter of this dissertation has shown that vanadate was able to increase Akt kinase activity and cause phosphorylation at Ser473 and Thr308. Akt-mediated phosphorylation of p21 was shown 
to cause its translocation from nucleus, thus preventing its inhibition of nuclear cdks (34). Evidence is now accumulating that PI3K signals are required together with ERK signaling for transcriptional induction of cyclin D1. This cyclin is necessary for cdk activation and for $\mathrm{G}_{1}$ progression (35). In our previous study, we have also shown that MAPKs are important mediators in vanadate-induced cell cycle arrest at S phase (20). While it appears that PI3K, p70S6K, Akt and MAPKs maybe all directly or indirectly involved in the regulation cell cycle regulatory proteins, $\mathrm{p} 21, \operatorname{cdc} 25 \mathrm{~A}$ and $\operatorname{cdk} 2$, the mechanisms of actions remain to be investigated.

In conclusion, the results obtained from the present study show that vanadate induced PI3K activation, which phosphated p70S6K. The activated p70S6K triggered its downstream protein, $40 \mathrm{~S}$ ribosomal protein $\mathrm{S} 6$, leading to activation of $\mathrm{p} 21$, decrease in cell cycle regulatory proteins, cdc $25 \mathrm{~A}$ and cdk 2 and caused cell cycle arrest at $\mathrm{S}$ phase. 


\section{VI.6. FIGURES}

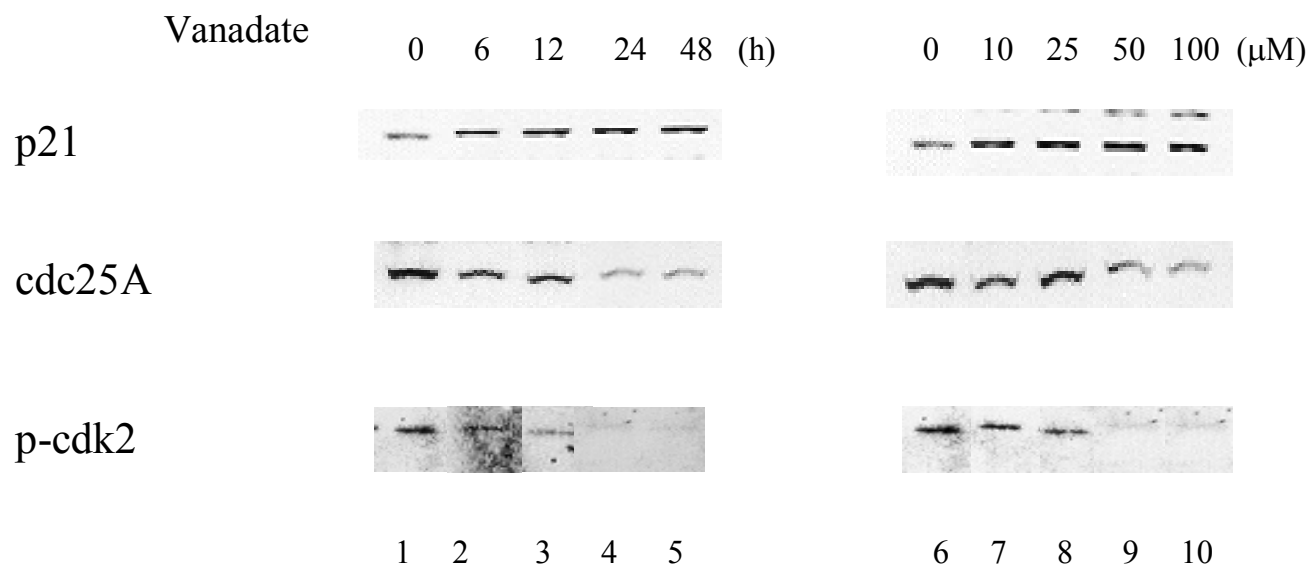

Figure 1 Effects of vanadate on cell growth regulatory proteins in both C141 cells and $\Delta$ p85 cells. C141cells were treated with $50 \mu \mathrm{M}$ vanadate for $6,12,24$ and 48 $\mathrm{h}$ and $10,25,50,100 \mu \mathrm{M}$ for $24 \mathrm{~h}$. The whole cell lysates were collected for Western blotting using specific antibodies aganist p21, cdc25A and p-cdk2 and p21. Lanes 1 and 6, control; lane 2, $50 \mu \mathrm{M}, 6 \mathrm{~h}$; lane 3, $50 \mu \mathrm{M}, 12 \mathrm{~h}$; lanes 4 and 9, $50 \mu \mathrm{M}, 24 \mathrm{~h}$; lane 5, $50 \mu \mathrm{M}, 48 \mathrm{~h}$; lane 7, $10 \mu \mathrm{M}, 24 \mathrm{~h}$; lane 8, $25 \mu \mathrm{M}, 24 \mathrm{~h}$; and lane 10, $100 \mu \mathrm{M}, 24 \mathrm{~h}$. Data from a single preparation representative of three independent experiments. 


\section{B}

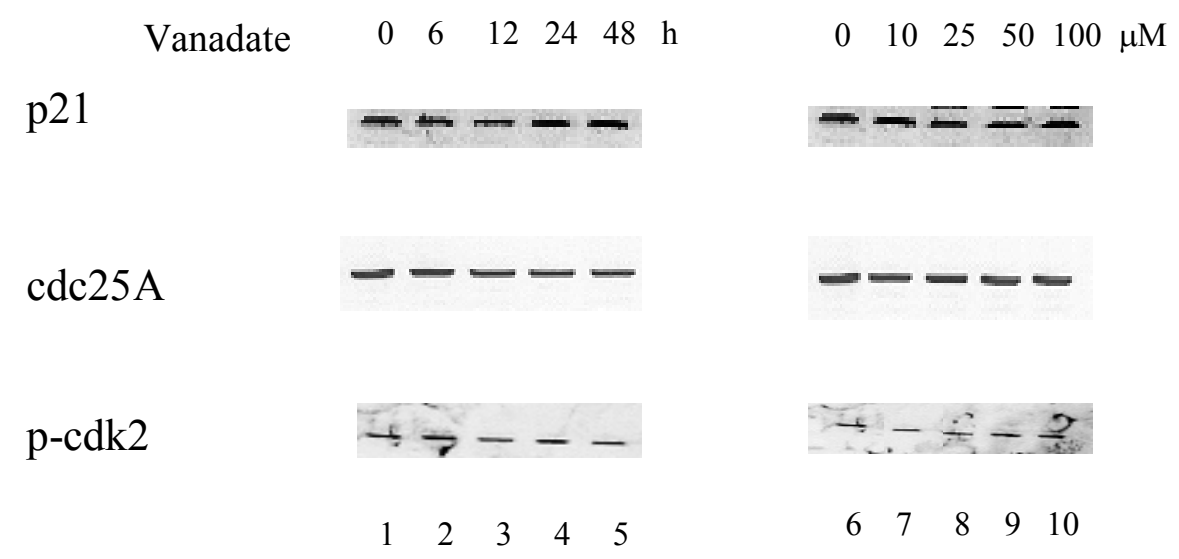

Figure 1 Effects of vanadate on cell growth regulatory proteins in both C141 cells and $\Delta$ p85 cells. $\Delta$ p85 cells were treated with $50 \mu \mathrm{M}$ vanadate for $6,12,24$ and 48 $\mathrm{h}$ and $10,25,50,100 \mu \mathrm{M}$ for $24 \mathrm{~h}$. The whole cell lysates were collected for Western blotting using specific antibodies aganist $\mathrm{p} 21, \operatorname{cdc} 25 \mathrm{~A}$ and $\mathrm{p}$-cdk2 and p21. Lanes 1 and 6, control; lane 2, $50 \mu \mathrm{M}, 6 \mathrm{~h}$; lane 3, $50 \mu \mathrm{M}, 12 \mathrm{~h}$; lanes 4 and 9, $50 \mu \mathrm{M}, 24 \mathrm{~h}$; lane 5, $50 \mu \mathrm{M}, 48 \mathrm{~h}$; lane 7, $10 \mu \mathrm{M}, 24 \mathrm{~h}$; lane 8, $25 \mu \mathrm{M}, 24 \mathrm{~h}$; and lane 10, $100 \mu \mathrm{M}, 24 \mathrm{~h}$. Data from a single preparation representative of three independent experiments. 
A

$\mathrm{a}$

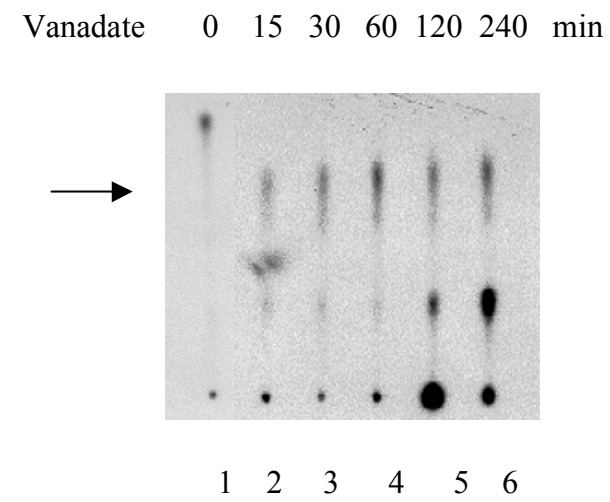

b

$\begin{array}{llllll}0 & 10 & 25 & 50 & 100 & \mu \mathrm{M}\end{array}$

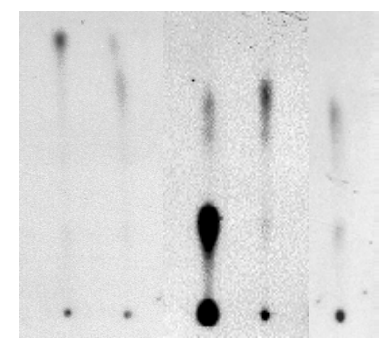

$\begin{array}{lllll}7 & 8 & 9 & 10 & 11\end{array}$

Figure 2 Effects of vanadate on PI3K activity and cell cycle regulatory proteins in C141 cells. The cells were treated with $50 \mu \mathrm{M}$ vanadate from 0 to $240 \mathrm{~min}$ and 10 , 25, 50, $100 \mu \mathrm{M}$ for $60 \mathrm{~min}$. The whole cell lysates were used to measure PI3K activity. Lanes 1 and 7, control; lane 2, $50 \mu \mathrm{M}, 15 \mathrm{~min}$; lane 3, $50 \mu \mathrm{M}, 30$ min; lanes 4 and 10, $50 \mu \mathrm{M}, 60 \mathrm{~min}$; lane 5, $50 \mu \mathrm{M}, 120 \mathrm{~min}$; lane 6, $50 \mu \mathrm{M}$, $240 \mathrm{~min}$; lane 7, $10 \mu \mathrm{M}, 60 \mathrm{~min}$; lane 8, $25 \mu \mathrm{M}, 60 \mathrm{~min}$; and lane 10, $100 \mu \mathrm{M}$, $60 \mathrm{~min}$. Data from a single preparation representative of three independent experiments. 


\begin{tabular}{|c|c|c|c|}
\hline LY294002 & $-\quad-$ & + & + \\
\hline Vanadate & $-\quad+$ & + & + \\
\hline p21 & -- & - & - \\
\hline $\operatorname{cdc} 25 \mathrm{~A}$ & - & - & - \\
\hline $\mathrm{p}-\mathrm{cdk} 2$ & - & - & - \\
\hline
\end{tabular}

Figure 2 Effects of vanadate on PI3K activity and cell cycle regulatory proteins in C141 cells. The cells were pretreated with LY294002 for 30 min followed by $50 \mu \mathrm{M}$ vanadate stimulation for $24 \mathrm{~h}$. The whole cell lysates were collected for Western blotting. Lanes 1, control; lane 2, $50 \mu \mathrm{M}$ vanadate; lane 3, $50 \mu \mathrm{M}$ vanadate $+10 \mu \mathrm{M} L Y$; and lane $4,50 \mu \mathrm{M}$ vanadate $+20 \mu \mathrm{M}$ LY. Data from a single preparation representative of three independent experiments. 
A

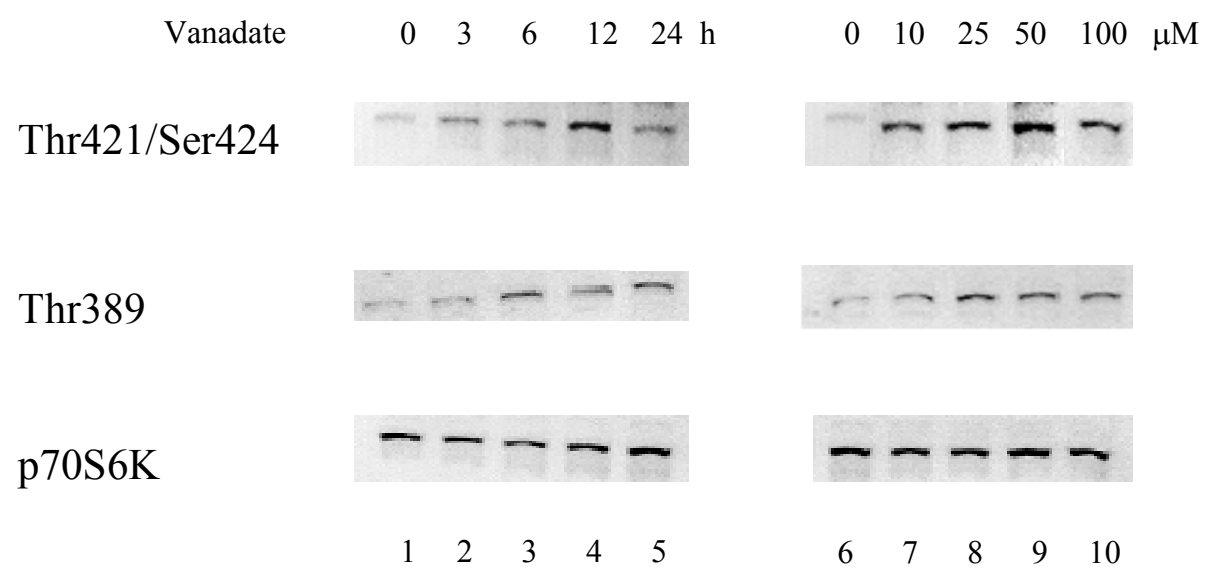

Figure 3 Effects of vanadate on p70S6K in both C141 cells and $\Delta$ p85 cells. C141 cells were treated with $50 \mu \mathrm{M}$ vanadate from 0 to $24 \mathrm{~h}$ and $10,25,50,100 \mu \mathrm{M}$ for $12 \mathrm{~h}$. Western blotting was used for measurement of phosphorylation of p70S6K. Lanes 1 and 7, control; lane 2, $50 \mu \mathrm{M}, 3 \mathrm{~h}$; lane 3, $50 \mu \mathrm{M}, 6 \mathrm{~h}$; lanes 4 and 9, $50 \mu \mathrm{M}, 12 \mathrm{~h}$; lanes 5, $50 \mu \mathrm{M}, 24 \mathrm{~h}$; lane 7, $10 \mu \mathrm{M}, 12 \mathrm{~h}$; lane 8, 25 $\mu \mathrm{M}, 12 \mathrm{~h}$; and lane 10, $100 \mu \mathrm{M}, 12 \mathrm{~h}$. Data from a single preparation representative of three independent experiments. 
B

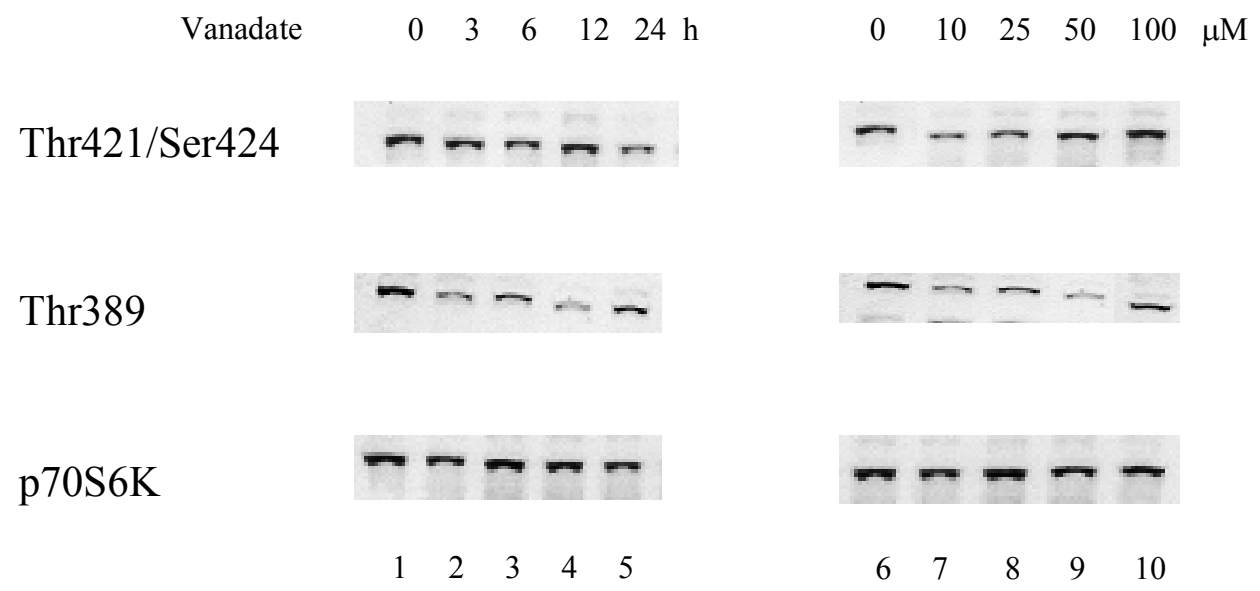

Figure 3 Effects of vanadate on $\mathrm{p} 70 \mathrm{~S} 6 \mathrm{~K}$ in both $\mathrm{C} 141$ cells and $\Delta \mathrm{p} 85$ cells. $\Delta \mathrm{p} 85$ cells were treated with $50 \mu \mathrm{M}$ vanadate from 0 to $24 \mathrm{~h}$ and $10,25,50,100 \mu \mathrm{M}$ for $12 \mathrm{~h}$. Western blotting was used for measurement of phosphorylation of p70S6K. Lanes 1 and 7, control; lane 2, $50 \mu \mathrm{M}, 3 \mathrm{~h}$; lane 3, $50 \mu \mathrm{M}, 6 \mathrm{~h}$; lanes 4 and 9, $50 \mu \mathrm{M}, 12 \mathrm{~h}$; lanes 5, $50 \mu \mathrm{M}, 24 \mathrm{~h}$; lane 7, $10 \mu \mathrm{M}, 12 \mathrm{~h}$; lane 8, 25 $\mu \mathrm{M}, 12 \mathrm{~h}$; and lane 10, $100 \mu \mathrm{M}, 12 \mathrm{~h}$. Data from a single preparation representative of three independent experiments. 
A
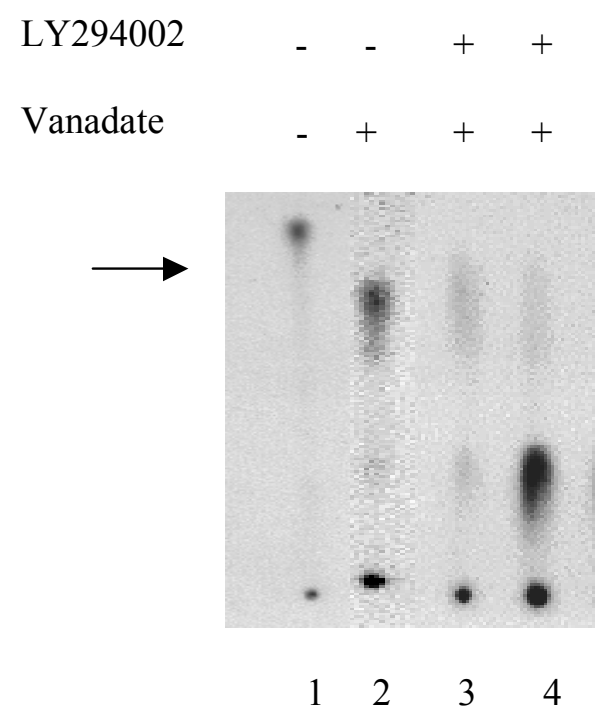

Figure 4 Effects of PI3K on p70S6K in C141 cells and in DN/p70S6K cells. The C141 cells were seeded in 6-well plates. After $80 \%$ confluence, the cells were pretreated with different concentrations of LY294002 before vanadate treatment $(50 \mu \mathrm{M})$. Kinase assay was used to detect PI3K activity. Lane 1, control without vanadate stimulation, $60 \mathrm{~min}$; lane 2, vanadate $60 \mathrm{~min}$; lane 3, vanadate $+10 \mu \mathrm{M} \mathrm{LY}, 60 \mathrm{~min}$; and lane 4, vanadate $+20 \mu \mathrm{M} \mathrm{LY}, 60 \mathrm{~min}$. Data from a single preparation representative of three independent experiments. 


\section{B}

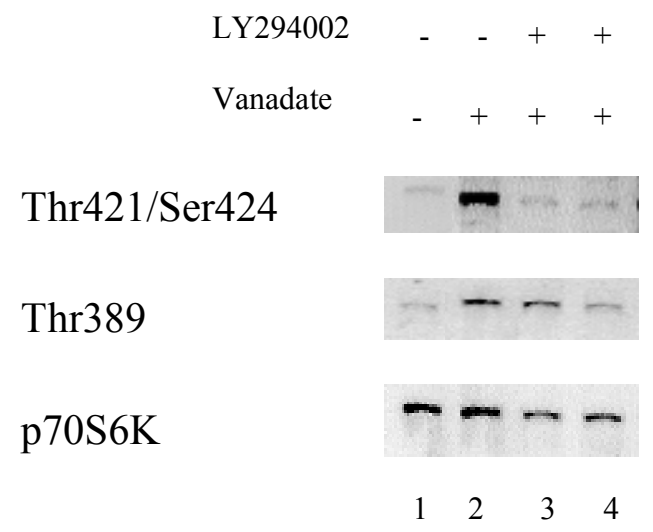

Figure 4 Effects of PI3K on p70S6K in C141 cells and in DN/p70S6K cells. The C141 cells were seeded in 6-well plates. After $80 \%$ confluence, the cells were pretreated with different concentrations of LY294002 before vanadate treatment (50 $\mu \mathrm{M})$. Western blotting was analyzed for measurement of p70S6K phosphorylation. Lane 1, control without vanadate stimulation; lane 2, vanadate; lane 3, vanadate $+10 \mu \mathrm{M} \mathrm{LY}$; and lane 4, vanadate $+20 \mu \mathrm{M} \mathrm{LY}$. Data from a single preparation representative of three independent experiments. 


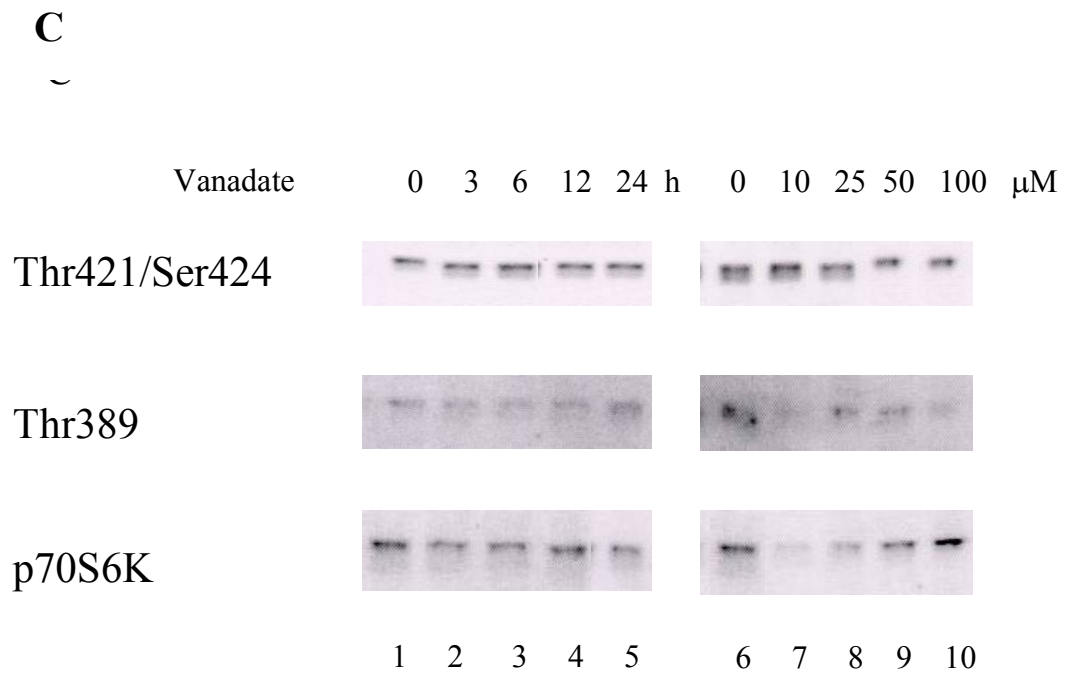

Figure 4 Effects of PI3K on p70S6K in C141 cells and in DN/p70S6K cells. The $\mathrm{DN} / \mathrm{p} 70 \mathrm{~S} 6 \mathrm{~K}$ cells were seeded in 6-well plates. After $80 \%$ confluence, the cells were treated with vanadate for different doses and times. Western blotting analysis was used for measurement of p70S6K phosphorylations. Lanes 1 and 6, control; lane 2, $50 \mu \mathrm{M}, 3 \mathrm{~h}$; lane 3, $50 \mu \mathrm{M}, 6 \mathrm{~h}$; lanes 4 and 9, $50 \mu \mathrm{M}, 12 \mathrm{~h}$; lanes 5, $50 \mu \mathrm{M}, 24 \mathrm{~h}$; lane 7, $10 \mu \mathrm{M}, 12 \mathrm{~h}$; lane 8, $25 \mu \mathrm{M}, 12 \mathrm{~h}$; and lane $10,100 \mu \mathrm{M}, 12 \mathrm{~h}$. Data from a single preparation representative of three independent experiments. 
A

a

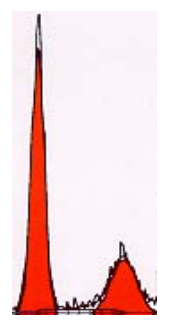

d

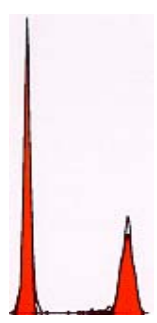

$\mathrm{b}$

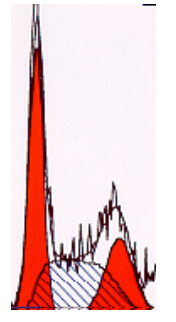

e

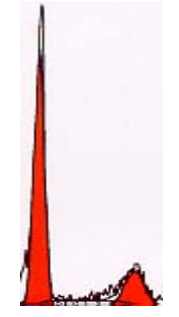

c

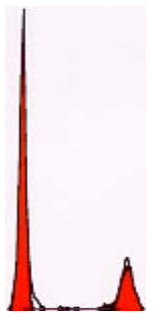

$\mathrm{f}$

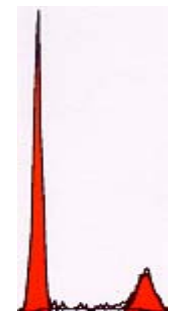

Figure 5 Effects of both PI3K and p70S6K on cell cycle arrest. The C141 cells were pretreated with different concentrations of LY294002 and rapmycin for $30 \mathrm{~min}$ before vanadate treatment $(50 \mu \mathrm{M}, 24 \mathrm{~h})$. DNA content was used to measure the percentage of the cells at $\mathrm{S}$ phase. a, control without stimulation; b, $50 \mu \mathrm{M}$ vanadate; c, $50 \mu \mathrm{M}$ vanadate $+10 \mu \mathrm{M} \mathrm{LY}$; d, $50 \mu \mathrm{M}$ vanadate $+20 \mu \mathrm{M}$ LY; e, $50 \mu \mathrm{M}$ vanadate $+10 \mu \mathrm{M}$ rapmycin; and $\mathrm{f}, 50 \mu \mathrm{M}$ vanadate $+20 \mu \mathrm{M}$ rapmycin. Data from a single preparation representative of three independent experiments. 
B

a

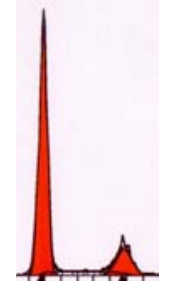

d

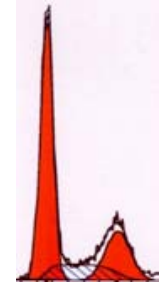

$\mathrm{b}$

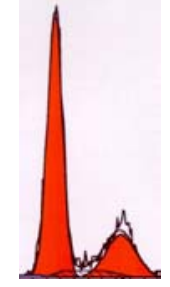

e

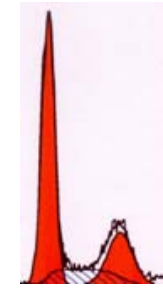

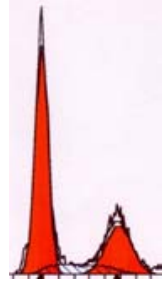

Figure 5 Effects of both PI3K and p70S6K on cell cycle arrest. DN/p70S6K cells were treated with $50 \mu \mathrm{M}$ vanadate for different time $(6,12,24$, and $48 \mathrm{~h})$. DNA content was used to measure the percentage of the cells at S phase. a, control; b, 6h; c, 12h; d, 24h; and e, 48h. Data from a single preparation representative of three independent experiments. 
C

a

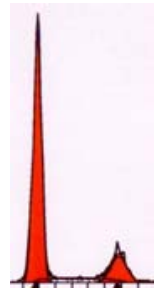

d

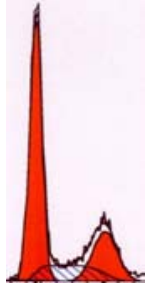

b

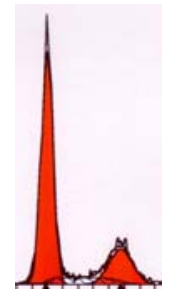

e

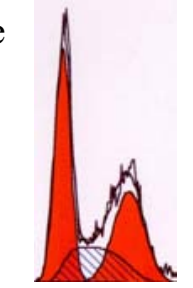

c

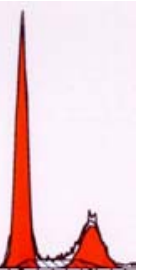

Figure 5 Effects of both PI3K and p70S6K on cell cycle arrest. DN/p70S6K cells were treated with different doses of vanadate $(10,25,50$, and $100 \mu \mathrm{M})$ for $24 \mathrm{~h}$. DNA content was used to measure the percentage of the cells at $\mathrm{S}$ phase. a, control; b, $10 \mu \mathrm{M}$; c, $25 \mu \mathrm{M}$; d, $50 \mu \mathrm{M}$; and e, $100 \mu \mathrm{M}$. Data from a single preparation representative of three independent experiments. 
D

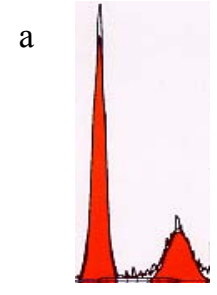

b

d

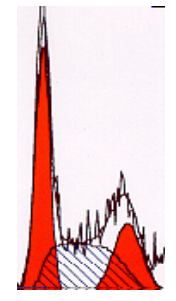

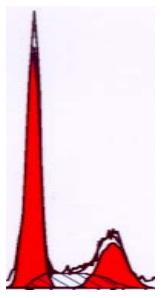

$\mathrm{c}$

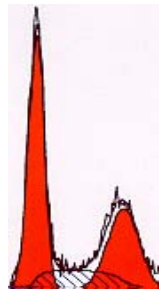

e

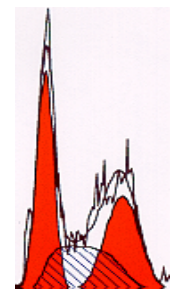

Figure 5 Effects of both PI3K and p70S6K on cell cycle arrest. C141 cells were treated with different time $(6,12,24$, and $48 \mathrm{~h})$. DNA content was used to measure the percentage of the cells at S phase. a, control; b, 6 h; c, 12 h; d, 24 h; and e, 48 h. Data from a single preparation representative of three independent experiments. 
a

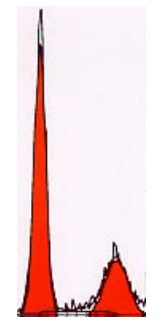

d

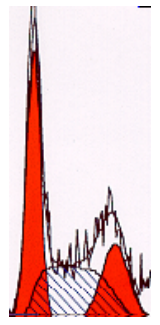

$\mathrm{b}$

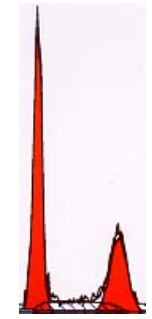

$\mathrm{c}$

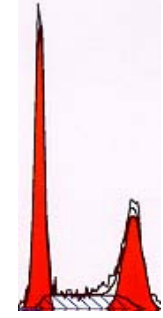

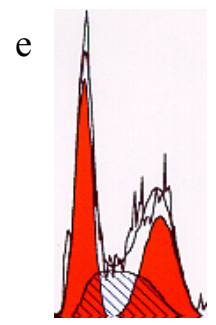

Figure 5 Effects of both PI3K and p70S6K on cell cycle arrest. C141 cells were treated with different doses of vanadate for $24 \mathrm{~h}$. DNA content was used to measure the percentage of the cells at S phase. a, control; b, $10 \mu \mathrm{M}$; c, $25 \mu \mathrm{M} ; \mathrm{d}, 50$ $\mu \mathrm{M}$; and e, $100 \mu \mathrm{M}$. Data from a single preparation representative of three independent experiments. 


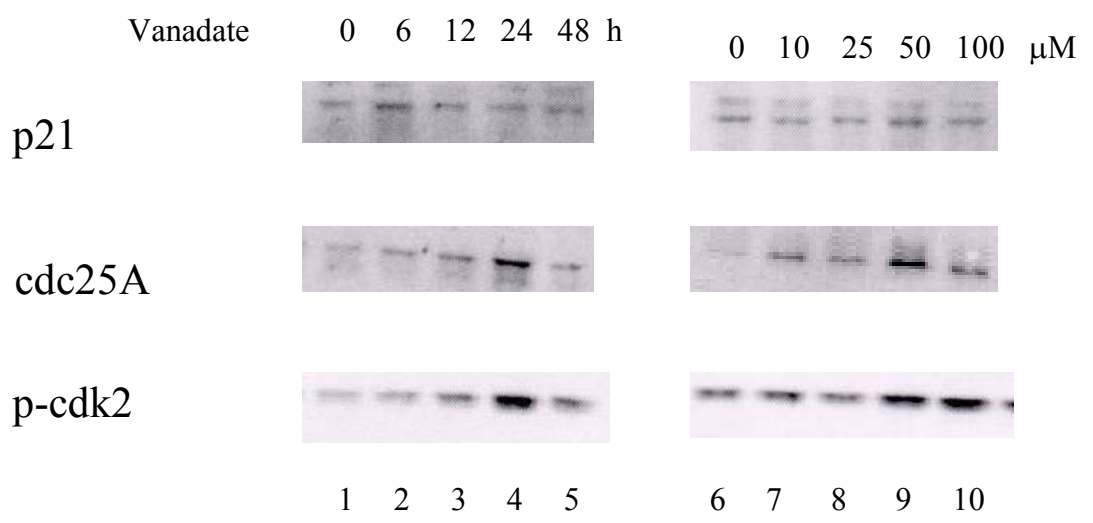

Figure 6 Role of $\mathrm{p} 70 \mathrm{~S} 6 \mathrm{~K}$ on cell cycle regulatory proteins. The DN/p70S6K cells were pretreated with vanadate at different time and doses. Western blotting was performed to examine the protein level of p-cdk2 and p21. Lanes 1 and 6, control; lanes 2, $50 \mu \mathrm{M} 6 \mathrm{~h}$; lane 3, $50 \mu \mathrm{M}, 12 \mathrm{~h}$; lanes 4 and 9, $50 \mu \mathrm{M}, 24 \mathrm{~h}$; lane 5, $50 \mu \mathrm{M}, 48 \mathrm{~h}$; lane 7, $10 \mu \mathrm{M}, 24 \mathrm{~h}$; lane 8, $25 \mu \mathrm{M}, 24 \mathrm{~h}$; and lane 10, 100 $\mu \mathrm{M}, 24 \mathrm{~h}$. Data from a single preparation representative of three independent experiments. 


\section{VI.7. REFERENCES}

1. Pope, C.A., 3rd, Thun M.J., Namboodiri M.M., Dockery D.W., Evans J.S., Speizer F.E. and Heath C.W., Jr. (1995) Particulate air pollution as a predictor of mortality in a prospective study of U.S. adults. Am J Respir Crit Care Med, 151, $669-74$.

2. Abelson, P.H. (1992) Exaggerated carcinogenicity of chemicals. Science, 256, 1609.

3. Abelson, P.H. (1997) Proposed air pollutant standards. Science, 277, 15.

4. Dockery, D.W. and Pope C.A., 3rd (1994) Acute respiratory effects of particulate air pollution. Annu Rev Public Health, 15, 107-32.

5. Kennedy, T., Ghio A.J., Reed W., Samet J., Zagorski J., Quay J., Carter J., Dailey L., Hoidal J.R. and Devlin R.B. (1998) Copper-dependent inflammation and nuclear factor-kappaB activation by particulate air pollution. Am J Respir Cell Mol Biol, 19, 366-78.

6. Kodavanti, U.P., Hauser R., Christiani D.C., Meng Z.H., McGee J., Ledbetter A., Richards J. and Costa D.L. (1998) Pulmonary responses to oil fly ash particles in the rat differ by virtue of their specific soluble metals. Toxicol Sci, 43, 204-12.

7. Ramasarma, T. and Crane F.L. (1981) Does vanadium play a role in cellular regulation? Curr Top Cell Regul, 20, 247-301.

8. Yin, X., Davison A.J. and Tsang S.S. (1992) Vanadate-induced gene expression in mouse C127 cells: roles of oxygen derived active species. Mol Cell Biochem, 115, 85-96.

9. Nechay, B.R. (1984) Mechanisms of action of vanadium. Annu Rev Pharmacol Toxicol, 24, 501-24.

10. Erdmann, E., Werdan K., Krawietz W., Schmitz W. and Scholz H. (1984) Vanadate and its significance in biochemistry and pharmacology. Biochem Pharmacol, 33, 945-50. 
11. Leonard, A. and Gerber G.B. (1994) Mutagenicity, carcinogenicity and teratogenicity of vanadium compounds. Mutat Res, 317, 81-8.

12. Sabbioni, E., Pozzi G., Pintar A., Casella L. and Garattini S. (1991) Cellular retention, cytotoxicity and morphological transformation by vanadium(IV) and vanadium(V) in BALB/3T3 cell lines. Carcinogenesis, 12, 47-52.

13. Shi, X., Jiang H., Mao Y., Ye J. and Saffiotti U. (1996) Vanadium(IV)-mediated free radical generation and related 2'- deoxyguanosine hydroxylation and DNA damage. Toxicology, 106, 27-38.

14. Hickey, R.J., Schoff E.P. and Clelland R.C. (1967) Relationship between air pollution and certain chronic disease death rates. Multivariate statistical studies. Arch Environ Health, 15, 728-38.

15. Stock, P. (1965) On the relations between atmospheric pollution in urban and rural location and mortality from cancer, bronchitis, pneumonia, with particular reference to 3,4-benzopyrene, beryllium, molybdenum, vanadium and arsenic. $\mathrm{Br}$ J Cancer, 14, 397-418.

16. Sherr, C.J. (1996) Cancer cell cycles. Science, 274, 1672-7.

17. Elledge, S.J. (1996) Cell cycle checkpoints: preventing an identity crisis. Science, 274, 1664-72.

18. Paulovich, A.G., Toczyski D.P. and Hartwell L.H. (1997) When checkpoints fail. Cell, 88, 315-21.

19. Zhang, Z., Huang C., Li J. and Shi X. (2002) Vanadate-induced cell growth arrest is p53-dependent through activation of p21 in C141 cells. J Inorg Biochem, 89, $142-8$.

20. Zhang, Z., He, H., Chen, F., Huang, C., and Shi, X. (2002) MAPKs mediate S phase arrest induced by vanadate through a p53 dependent pathway in mouse epidermal C141 cells. Chem Res Toxicol in press

21. Zhang, Z., Chen, F., Huang C., Shi, X. (2002) Vanadate induces G2/M phase arrest in p53 deficient mouse embryo fibroblasts. $J$ Environ Pathol Toxicol. Oncol in press 
22. Krasilnikov, M.A. (2000) Phosphatidylinositol-3 kinase dependent pathways: the role in control of cell growth, survival, and malignant transformation. Biochemistry (Mosc), 65, 59-67.

23. Toker, A. (2000) Protein kinases as mediators of phosphoinositide 3-kinase signaling. Mol Pharmacol, 57, 652-8.

24. Sgonic, R.a.W., G (1994.) Methods for the detection of apoptosis. Int Arch Allergy Immunol, 105, 327-332.

25. Nicoletti, I., Migliorati, G., Pagliacci, M.C., Grignani, F. and Riccardi, C. (1991) A rapid and simple method for measuring thymocyte apoptosis by propidium iodide staining and flow cytometry. J Immunol Methods, 139, 271-279.

26. Morgan, D.O. (1995) Principles of CDK regulation. Nature, 374, 131-4.

27. Lew, D.J. and Kornbluth S. (1996) Regulatory roles of cyclin dependent kinase phosphorylation in cell cycle control. Curr Opin Cell Biol, 8, 795-804.

28. Sherr, C.J. and Roberts J.M. (1995) Inhibitors of mammalian G1 cyclindependent kinases. Genes Dev, 9, 1149-63.

29. Draetta, G. and Eckstein J. (1997) Cdc25 protein phosphatases in cell proliferation. Biochim Biophys Acta, 1332, M53-63.

30. Hoffmann, I., Draetta G. and Karsenti E. (1994) Activation of the phosphatase activity of human cdc25A by a cdk2-cyclin E dependent phosphorylation at the $\mathrm{G} 1 / \mathrm{S}$ transition. EMBO J, 13, 4302-10.

31. Jefferies, H.B., Fumagalli S., Dennis P.B., Reinhard C., Pearson R.B. and Thomas G. (1997) Rapamycin suppresses 5'TOP mRNA translation through inhibition of p70s6k. EMBO J, 16, 3693-704.

32. Amaldi, F. and Pierandrei-Amaldi P. (1997) TOP genes: a translationally controlled class of genes including those coding for ribosomal proteins. Prog Mol Subcell Biol, 18, 1-17.

33. Katso, R., Okkenhaug K., Ahmadi K., White S., Timms J. and Waterfield M.D. (2001) Cellular function of phosphoinositide 3-kinases: implications for development, homeostasis, and cancer. Annu Rev Cell Dev Biol, 17, 615-75. 
34. Zhou, B.P., Hu M.C., Miller S.A., Yu Z., Xia W., Lin S.Y. and Hung M.C. (2000) HER-2/neu blocks tumor necrosis factor-induced apoptosis via the Akt/NFkappaB pathway. $J$ Biol Chem, 275, 8027-31.

35. Phillips-Mason, P.J., Raben D.M. and Baldassare J.J. (2000) Phosphatidylinositol 3-kinase activity regulates alpha -thrombin- stimulated G1 progression by its effect on cyclin D1 expression and cyclin-dependent kinase 4 activity. $J$ Biol Chem, 275, 18046-53. 


\section{OVERALL CONCLUSIONS}

1. Vanadate is able to cause the generation of ROS, which up-regulate ERK and p38. These MAPK members regulate cell growth regulatory proteins, cdc $25 \mathrm{C}$ and $\mathrm{p} 21$, leading to cell cycle arrest at $\mathrm{G}_{2} / \mathrm{M}$ phase.

2. Vanadate is capable of inducing $\mathrm{S}$ phase arrest, and this interruption of cell cycle progression is p53-dependent. Activation of p53 leads to an increase in p21 expression, resulting in a pause in growth progression at $\mathrm{S}$ phase.

3. Vanadate causes activation of both ERK and p38, and p53. Vanadate-induced S phase arrest is mediated by MAPKs through p53-dependent pathway.

4. The dependency of p53 is both cell type- and phase-specific. Vanadate is able to induce p53-independent $\mathrm{G}_{2} / \mathrm{M}$ phase arrest, and cdc25C, but not $\mathrm{p} 21$, is responsible for this type of arrest.

5. Vanadate increased Akt kinase activity and caused its phosphorylation. The activation of Akt affected on the E2F1/pRb complex, leading to the transition of $\mathrm{G}_{1}$ to $\mathrm{S}$ phase. PI3K/Akt plays an essential role in vanadate-induced $\mathrm{S}$ phase arrest through E2F1-pRb pathway.

6. Vanadate induced PI3K activation, which phosphated p70S6K at Thr421/Ser424 and Thr389 sites. The activated p70S6K triggered its downstream protein, 40S ribosomal protein S6, leading to activation of p21 and decrease in cell cycle regulatory proteins, resulting in cell cycle arrest at $\mathrm{S}$ phase. 


\section{CURRICULUM VITAE}

\section{Education}

1999 - present School of Pharmacy, West Virginia University, Ph. D. degree candidate

1990 - 1993 Zhejiang Medical University, MPH, Hangzhou, Zhejiang, P. R. China

1985 - $1990 \quad$ Fujian Medical College, MD, Fuzhou, Fujian, P. R. China

\section{Work Experience}

$1998-1999$

Chinese Medical Board (CMB) Advanced Fellowship in Occupational and Environmental Health, Dept. of Community, Occupational and Family Medicine, National University of Singapore, Singapore

1996 - 1998 Lecturer, Dept. of Pneumoconiosis, Medical School of Zhejiang University, P. R. China

1993 - 1996 Teaching and Research Assistant, Zhejiang Medical University, P. R. China

\section{Awards and Honors}

1999 Excellent presentation award in National Conference of Prevention Pneumoconiosis, PR China

1996 The Third Prize for Progression on Science and Technology by Zhejiang Province, PR China

1994 Excellent thesis award in Natural Sciences in ZHejiang Province, PR China 


\section{Publications}

1. Zhang Z, Gao N, Huang C, Chen F, He H, Shi X. Invovlement of E2F1-pRb in vanadate-induced $\mathrm{S}$ phase arrest through Akt pahtway. In preparation

2. Zhang Z, Gao N, Huang C, Chen F, He H, Vallyathan V, Shi X. The role of phosphatidylinositol-3 kinase and p70 S6 kinase in vanadate-induced S phase arrest. In preparation

3. Zhang Z, Leonard SS, Qian Y, Chen F, Huang C, Vallyathan V, Catranova V, Shi X. Vanadate induces cell growth arrest through MAPKs and reactive oxygen species. In preparation

4. Gao N, Flynn DC, Zhang Z, Chen B, Walker V, Lin J, Liu K, Shi X, Jiang B. The $\mathrm{G}_{1}$ cell cycle progression and the expression of $\mathrm{G}_{1}$ cyclins are regulated by $\mathrm{PI} 3 \mathrm{~K} / \mathrm{AKT} / \mathrm{mTOR}$ signaling in human ovarian cancer cells. In preparation

5. Gao N, Jiang B, Leonard SS, Corum L, Zhang Z, Boberts J, Antonini J, Zheng J, Flynn D, Shi X. Chromium (VI) induced expression of hypoxia-inducible factor 1 and vascular endothelial growth factor in DU145 human prostate carcinoma cells through reactive oxygen species. In preparation

6. Gao N, Ding M, Zheng J, Zhang Z, Leonard SS, Liu K, Shi X, Jiang B. Vanadate induced expression of hypoxia-inducible factor 1 and vascular endothelial growth factor through phosphatidylinositol 3-kinase/Akt pathway and reactive oxygen species. In preparation

7. Zhang Z, He H, Chen F, Huang C, Shi X. MAPKs mediate S phase arrest induced by vanadate through a p53 dependent pathway in mouse epidermal JB6 cells. Chem. Res. Toxicol. In press

8. Zhang Z, Chen F, Huang C, Shi X. Vanadate induces $\mathrm{G}_{2} / \mathrm{M}$ phase arrest in $\mathrm{p} 53$ deficient mouse embryo fibroblasts. J Environ Pathol Toxicol Oncol. In press

9. Zhang Z, Huang C, Li J, Shi X. Vanadate-induced cell growth arrest is p53dependent through activation of p21 in C141 Cells. J. Inorg. Biochem. 89:142-8, 2002 
10. Chen F, Zhang Z, Bower J, Lu Y, Leonard SS, Ding M, Castranova C, PiwnicaWorms H, Shi X. Arsenite-induced Cdc25C degradation is through the KEN-box and ubiquitin-proteasome pathway. Proc. Natl. Acad. Sci. 99(4): 1990-5, 2002

11. Huang C, Li J, Costa M, Zhang Z, Leonard SS, Castranova V, Vallyathan V, Ju G, Shi X. Hydrogen peroxide mediates activation of nuclear factor of activated T cells (NFAT) by nickel subsulfide. Cancer Res. 61 (22): 8051-7, 2001

12. Zhang Z, Leonard SS, Wang S, Vallyathan V, Castranova V, Shi X. Cr (VI) induces cell growth arrest through hydrogen peroxide-mediated reaction. Mol. Cell. Biochem. 222 (1-2): 77-83, 2001

13. Zhang Z, Huang C, Li J, Leonard SS, Lanciott R, Butterworth L, Shi X. Vanadate-induced cell growth regulation and the role of reactive oxygen species. Arch. Biochem. Biophy. 392 (2): 311-20, 2001

14. Qian Y, Jiang B, Leonard SS, Wang S, Zhang Z, Ye J, Chen F, Wang L, Shi X, Flynn DC. Cr (VI) increases tyrosine phosphorylation through reactive oxygen species-mediated reactions. Mol. Cell. Biochem. 222 (1-2): 199-204, 2001

15. Liu K, Husler J, Ye J, Culter D, Leonard SS, Chen F, Wang S, Zhang Z, Wang L, Shi X. On the mechanism of Cr (VI)-induced carcinogenesis: dose dependence of cellular responses. Mol. Cell. Biochem. 222 (1-2): 221-9, 2001

16. Chen F, Zhang Z, Leonard SS, Shi X. Constrasting roles of NF- $\kappa B$ and JNK in arsenite-induced p53-independnet expression of GADD45 $\alpha$. Oncogene 20: 35853589,2001

17. Chen F, Lu Y, Zhang Z, Vallyathan V, Ding M, Castranova C, Shi X. Opposite effect of NF- $\kappa \mathrm{B}$ and c-jun-N-terminal kinase on p53-independent GADD45 induction by arsenite. J. Biol. Chem. 276 (14): 11414-11419, 2001

18. Shen H, Zhang Z, Zhang Q, Ong C. Reactive oxygen species and caspase activation mediated silica-induced apoptosis in alveolar macrophages. Am. J. Physiol. 280: L10-17, 2001 
19. Huang C, Zhang Z, Ding M, Li J, Leonard SS, Shen H, Lu Y, Castranova V, Vallyathan V, Shi X. Vanadate (V)-induced apoptosis through hydrogen peroxide-mediated p53-dependent pathway. J. Biol. Chem. 275: 32516-22, 2000

20. Zhang Z, Shen H, Zhang Q, Ong C. Involvement of oxidative stress in silicainduced cytotoxicity and genotoxicity in alveolar macrophages. Environ. Res. 82: 245-252, 2000

21. Zhang Z, Shen H, Zhang Q, Ong C. Critical role of glutathione in silica-induced oxidative stress, cytotoxicity and genotoxicity in alveolar macrophages. Am. J. Physiol. 277: L743-48, 1999

\section{Abstract, Posters and Presentations}

Vanadate induces cell growth arrest through MAP kinase and ROS. Zhang Z Leonard SS, Qian Y, Chen F, Huang C, Vallyathan V, Castranova V, Shi X. Poster presented in $3^{\text {rd }}$ International Conference on Oxygen/Nitrogen Radicals: Cell Injury and Disease, Morgantown, WV, 2002.

Role of lung surfactant in phagocytic clearance of apoptotic cells by macrophages during the development of pulmonary inflammation and fibrosis. Wang L, Scabilloni JF, Rojanasakul Y, Antonini J, Zhang Z, Castranova V, and Mercer RR. Poster presented in Experimental biology meeting. New Orleans, LA, 2002

Arsenite modulation of the integrity of actin filaments and the increase in cell motility may be mediated through CDC42. Qian Y, Zhang Z, Flynn D, Shi X. Poster presented in Experimental biology meeting. New Orleans, LA, 2002

Presented PPRB branch seminar entitled "Vanadate induces cell growth arrest through MAP kinase and ROS" at NIOSH, Morgantown, WV, 2001. 
Presented seminar entitled "The role of phosphoinositide-3 kinase in vanadateinduced cell cycle regulation" at West Virginia University, Morgantown, WV 2001

Vanadate-induced cell growth regulation and the role of reactive oxygen species.

Zhang Z, Huang C, Li J, Leonard SS, Lanciott R, Butterworth L, Shi X. $8^{\text {th }}$ Oxygen Society Annual Meeting, San Diego, CA, 2000 